Szegedi Tudományegyetem

Bölcsészettudományi Kar

PHD-ÉRTEKEZÉS

Bordás Sándor

\title{
A TRÓPUSOK MESEKERTJE
}

METAFORIKUS PRÓZAVÁLTOZATOK A MODERNITÁS POÉTIKÁJÁBAN

IRODALOMTUDOMÁNYI DOKTORI ISKOLA

Modern magyar irodalom doktori program

TÉMAVEZETŐ:

Dr. Virág Zoltán

egyetemi docens

Szeged

2009 


\section{TARTALOM}

A trópusok virágai - metaforavirágzás (bevezetés)

I. „...árnyék rajtunk és bennünk" - mese, metafora, elbeszélés $\ldots \ldots \ldots \ldots \ldots \ldots \ldots \ldots \ldots$

1. Metafora-kontextusok: metafora a prózapoétikában $\quad$........................ 12

2. A mese mint narratív forma: mese és metaforikusság $\quad \ldots \ldots \ldots \ldots \ldots \ldots \ldots \ldots \ldots \ldots \ldots$

II. A varázsló kertjéből a sétapálca-erdőbe -

mese és metaforikusság Csáth Géza és Szini Gyula szövegtereiben .............. 29

1. Mesék, amelyek rosszul végződnek: Csáth Géza prózájáról ............... 33

Mesealakulatok: mese-formulák és az elbeszélői keret ..................... 36

(A köszívü takaritónő, Mese az emberek rosszságáról, A mester meséi)

Körül-írás: a mese müfaji és tematikus elemei; a mesei jelképek $\quad . . \ldots \ldots \ldots \ldots . . .40$

(Pesti mese, A varázsló kertje, Történet a három leányokról)

Visszhang és áthangolás: mesehagyomány és figurativitás

(Szombat este, Anyagyilkosság, A béka)

2. Mese-árnyak az elbeszélés sürüjében: Szini Gyula novellisztikája

„Keleti drágakövek” vs. „, türelemjáték kövei”:

egy ,elméletpótló esszé” mesefogalma

(A mese , alkonya”)

Az imaginárius topográfiája:

mesei visszfény és metaforikus útvesztők az elbeszélésben

( A smaragd, A rózsaszinü hó, A sétapálca-erdö)

III. Nyelvesap(ol)ások - a metaforikus próza változatai a mai magyar irodalomban ...

1. „Az érinthetőn át az érinthetetlent..."

(Déry Tibor Szerelem című novellájának és Makk Károly filmjének olvasata) .. 118

2. „Írni, mintha mondanám. Hogy olvassa mintha hallaná.” 136

(Závada Pál: Milota)

3. „Szótestkupac” - (test)építés és (papír)hajtogatás

(Zalán Tibor Papírvárosai)

Könyörtelen éden, avagy a szövegterek burjánzása (összegzés)

Bibliográfia 


\section{A trópusok virágai - metaforavirágzás}

(bevezetés)

„...illatosak, melegek és finomak: élö, most szakított virágok, melyek irreális, csodálatos mezőkröl valók, de éppen a maguk szerves, tökéletes, kétségbevonhatatlanul élő voltával bizonyítják, hogy az utazó valóban ott járt, új és ismeretlen dimenziójú világokban."

Tóth Árpád ${ }^{1}$

A gyanútlan járókelőnek talán meglepő, hogy Görögországban sétálva a városszerte látható METAФOРЕ $\Sigma$ feliratok egyszerüen annyit jelentenek, hogy fuvarozás, szállítás (lásd Volán, Tefu). A görög szó - az autóbusztól a vegytisztító cégek kamionjain olvasható ${ }^{2}-$ köznapi jelentésének hátterében a latin translatio görög tükörfordítása: a metaphora áll. A metafora ugyanakkor olyan nyelvi jel, amely - klasszikus retorikai és fordításelméleti kérdéseket is felvetve - egyszersmind kulturális kontextusa hordozója is. Visszaélés a nyelvvel, az elnevezésekkel, más szövegformákkal: a metaforikus, inkább az idegen, mintsem a saját kifejezésének az eszköze. ${ }^{3}$

A metafora Arisztotelész óta az egyik leggyakrabban használt kifejezés a klasszikus poétikáktól egészen köznapi alkalmazásáig, legyen az turistalátványosság vagy köznyelvi fordulat, mindenütt felüti fejét (vö. „,ne legyél már ilyen metaforikus”, ti. titokzatos, elvont stb.). ${ }^{4}$ Előfordulása nem szükíthető az irodalomtudományra, vizsgálatát megnehezítik a hagyományos retorikáig visszanyúló gyökerei és a stilisztikai stúdiumok részeként megkövesedett iskolapéldái. Csupán a metaforával foglalkozó szakirodalom könyvtárnyi, nem számítva a fogalomnak a társtudományokban és az utóbbi évtizedben egyéb humán tudományterületeken tapasztalható reneszánszát vagy a „metaforamániát”. 5

Mindebből adódóan e disszertáció a metafora-fogalom történeti áttekintését mellőzve, és csak néhol érintve stilisztikai-retorikai kutatásokat, elsősorban az alapfogalom

\footnotetext{
${ }^{1}$ Tóth Árpád: Szini Gyula: Die gelbe kalesche. (Magyarische Bücher: 1.) Nyugat, 1914/12. 22.

${ }^{2}$ Szigeti Lajos Sándor 2002-es szíves szóbeli közlése alapján.

${ }^{3}$ Vö. Patricia PARKER: Metafora és katakrézis. Ford.: Nagy S. Attila. In: FÜZI Izabella - OdORICS Ferenc (szerk.): Figurák. Osiris - Pompeji, Bp., - Szeged, 2004. 43-60.

${ }^{4}$ Jacques DeRRIDA: A retorika virágai: a napraforgó. (Ford.: Gyimesi Tímea.) In: Határ, 1994/2. 27-38. illetve: http://whistler.uw.hu/meri/textar/derridaretorikaviragai.doc (2008. 08. 16.)

${ }^{5}$ Ahogy arra Bezeczky Gábor alapvető fontosságú könyvének Metaforamánia és narrációtéboly címü fejezetében felhívja a figyelmet: „Warren Shibles metafora-bibliográfiája láttán Wayne C. Booth arra a következtetésre jutott, hogy egyedül 1977-ben valószínűleg többet írtak a metaforáról, mint 1940 előtt összesen. (Warren SHILES: Metaphor: An Annotated Bibliography and Historz. Whitewater, The Language Press, 1971.) Hozzátette ehhez: ha ez a tendencia változatlan ütemben folytatódik száz éven át, 2039-ben az a képtelen helyzet állhat elö, hogy akkor többen fogják tanulmányozni a metaforát, mint ahány ember él majd a Földön. Mark Johnson Booth megjegyzései alapján hozta létre a »metaforaörület« (metaphormania) kifejezést. (BEZECZKY Gábor: Metafora, narráció, szociolingvisztika. Akadémiai, Bp., 2002. 174-180.)
} 
interdiszciplináris előfordulásával, változásával összefüggésben a metaforikusság, a metaforikus szerveződés prózapoétikai jellemzőit érinti. A metaforaelméletek tételes áttekintése és tudománytörténeti összefoglalása helyett elsősorban azt vizsgálja, hogy milyen elbeszéléstechnikai, narratológiai összefüggései, illetve szövegszerű megjelenései lehetnek a trópusoknak, a metaforikusságnak a prózában, elbeszélö szövegekben.

A metafora és narráció kapcsolatának kutatása ma már természetesen nem számít újdonságnak, a téma tudományelméleti feldolgozását és társasnyelvészeti összefüggéseinek bemutatását legutóbb Bezeczky Gábor kitűnő könyvében magyar nyelven is részben elvégezte. ${ }^{6}$

A retorika 1970-es években lezajló újjáéledésének nyomán az alakzatok és trópusok - az antik szónoklattanokig visszanyúló, és a 19 századi stilisztikákban megőrzött - tanai kitágulnak, a szigorú kategóriák elmosódnak és megtermékenyítő burjánzásba kezdenek az irodalmi prózanyelv és a filozófia, majd a legkülönbözöbb diszkurzusok, narratívák, a képzőmüvészet és a kultúra szerteágazó jelenségeit érintve. Jurij Lotman és a kultúrszemiotika ezeket a trópusokat, mint kulturális kódokat a szöveg és kontextus fogalmával kapcsolta össze. Ily módon a metafora is retorikai jelenségböl, szövegszervező alakzatból nemcsak a kultúra jelenségeit, strukturális szerveződéseit leíró jellemzővé, hanem mindezt nagymértékben meghatározó jelenséggé vált. ${ }^{7}$

A dolgozat egyik alapvető megközelítési szempontja, hogy a kultúra legkülönbözőbb területei, jelenségei jegyében vizsgálhatók a kommunikáció és a nyelv szemiotikai összefüggései. Kommunikációelméleti szempontból a kulturális kódok akár a vallás, jog, müvészetek vagy a hétköznapi élet jelenségeit érintsék is, a dekódolás és az ezt végző interpretáns viszonylatában értelmezhetők. ${ }^{8}$ A szemiotika ezeket a kimeríthetetlen és kultúránként változó kódokat a szöveg és kontextus fogalmával kapcsolta össze. ${ }^{9}$

${ }^{6}$ BeZECZKy Gábor: Metafora, narráció, szociolingvisztika. Akadémiai, Bp., 2002.

${ }^{7}$ Lásd többek között Hans BluMENBERG metaforológiai tanulmányait: Vö. Uö.: Hajótörés nézővel. (A mítosz valóságfogalma és hajtóereje; Paradigmák egy metaforológiához. Metaforológiai tanulmányok.) Ford.: Király Edit. Atlantisz, Bp., 2006. és Susan SonTAG a betegséget és az AIDS-et mint metaforát tárgyaló írásait. Vö. Uö.: A betegség mint metafora. Ford. Lugosi László. Európa, Bp., 1983.; illetve Uő.: Az AIDS és metaforái (esszé). Ford.: Rakovszky Zsuzsa. Európa, Bp., 1990.; vagy FARAGÓ Kornéliának az idegenség alakzataival foglalkozó könyvét. Vö. Uö.: Kultúrák és narrativák. Forum, Újvidék, 2005.

${ }^{8}$ Vö. Jurij LOTMAN: Kultúra és intellektus. (Jurij Lotman válogatott tanulmányai a szöveg, a kultúra és a történelem szemiotikája köréből.) Ford., szerk., elö- és utószó: SzITÁR Katalin. Argumentum, ELTE, Bp., 2002.

${ }^{9}$ Voigt Vilmos alapvető könyvének példájából kiindulva egy személyes tárgy vagy ereklye nem csupán a keresztény szentekkel kapcsolatban, hanem más vallások jelentős (valós vagy fiktív) figurái, politikai vezérek, a könnyüzene vagy a sport sztárjai szempontjából egyaránt fontos lehet. Michael Jackson orra, Che Guevara sapkája. Michael Jordan cipője, persze más megítélés alá esik egy árverésen, mint például a róluk írott életrajzi könyvben. Vö. VoIGT Vilmos: Szemiotikai kultúra - a kultúra szemiotikája. A debreceni Kossuth Lajos Tudományegyetem Néprajzi Tanszéke, Debrecen, 1990. 31. 
Egy kultúra jelei, jelrendszerei például egy szokás minden kísérőjelenségével (pl. esküvő, temetés), vagy egy pszichiátriai kezelés az összes apró részletével együtt, szövegekben nyilatkozik meg, így „nem csupán a szövegekböl következtethetünk egy kultúrára, hanem maga a kultúra hoz létre olyan megnyilvánulásokat, amelyeket szövegnek tekinthetünk". ${ }^{10}$

A kultúra metaforái és a kulturális metaforák müfaji, nyelvi és stiláris aspektusai a modern müvészetek és az irodalmi diszkurzus lényegi jellemzőjévé váltak. Hegyi Lóránd nem véletlenül tartja leírhatónak a modern és posztmodern müvészet individuumszemléletének változását a stílusmetaforák és a kulturális metafora révén. „A »posztmodern« szituációk művészete a »kulturális metafora« szubjektivizálásával fogalmazza meg a maga esztétikai valóságát. Müvészi önértelmezésében a korábbi stílusok elemei csupán »stílusmetaforák«, melyekben a tradíció újraértelmezése, a szubjektív valóságteremtés »múlthoz« és »helyhez« való viszonya, a mítosz aktualizálásának lehetősége, a kultúrtörténet egyes mozzanatainak újraköltése nyilvánul meg. A müvészi én ilyenkor jellegzetesen »posztmodern« fantázia alkotta »stílusmetaforákon« keresztül nyilatkozik meg, melyek a müvészi önteremtés képzeleti díszletei: a kulturális és művészeti identitás keresésének terei. Ezekben a terekben a müvészettörténet stílusai, motívumai, szimbólumai és képi metaforái újra személyes jelentőségre tesznek szert. A »posztmodern« szituációkban tehát a modern mủvészi Én a megváltozott környezet kihívásaira keres választ - a »kulturális metafora« személyre vonatkoztatott képeiben."

A szemiotika, a kommunikáció elmélete vagy a kultúra teoretikusai a metaforát a legkülönbözőbb diszkurzusok részeként olyan kontextusba helyezték, ${ }^{12}$ mely nemhogy rögzítené, kijelölné e trópus müfaji, stilisztikai, retorikai alapozású használatát, hanem éppen a vele kapcsolatba kerülő jelenségek, narratívák újraértelmezését, aktualizálását segíti elő. ${ }^{13}$ A metafora amellett, hogy nagy múltú poétikai, retorikai használatával számos nyelvi, stiláris vagy akár müfaji kérdéssel érintkezik, mint alapvető gondolkodást meghatározó séma, kognitív mechanizmus, szintén jelen van egyes filozófiai mủvészetelméleti vélekedésekben. ${ }^{14}$

\footnotetext{
${ }^{10}$ VoigT Vilmos: i. m. 33.

${ }^{11}$ HeGYI Lóránd: Avantgarde és transzavantgarde. (A modern müvészet korszakai.) Magvető, Bp., 1986. 73.

${ }^{12}$ Lásd pl. Martin J. GANNON (ed.): Cultural metaphors: readings, research translations, and commentary. Thousand Oaks, California, 2001.

${ }^{13}$ Lásd PETŐFI S. János nyelvészeti indíttatású szemiotikai-szövegtani kutatásában a metafora és a kultúra összefüggéseit. Vö. Uö.: A szöveg mint komplex jel. (Bevezetés a szemiotikai-textológiai szövegszemléletbe.) Akadémiai, Bp., 2004.

14 Vö. Arthur C. DANTO könyvének Nyelv, müvészet, kultúra szöveg címü fejezetével. = Uö.: Hogyan semmizte ki a filozófia a müvészetet? Ford.: Babarczy Eszter. Antlantisz, Bp., 1997. 83-94.; illetve Douwe
} 
A dolgozat azonban meg sem kísérli a metafora fogalomtörténeti áttekintését, vagy a metaforaelméletek összegzését, sem pedig a metafora-fogalom interdiszciplináris használatának, előfordulásának tételes bemutatását. A disszertáció kitüntetett célja inkább, hogy a metaforikusságot mint alapvető viszonyt, a figurativitás e meghatározó területét, felhasználja a szövegértelmezésben, összhangban ennek az irodalomtudományos újraszituálásának az eredményeivel.

A kulturális metaforák szövegszerveződéseinek, a kognitív metaforikusság narratív jellegének vagy a retorikai hagyomány textuális, müfaji aspektusainak viszonyrendszerében az emlékezet-mese-kultúra kapcsolódási pontjaiban meghatározó a metafora és a mese mint egyszerủ forma egymáshoz való viszonya. Az értekezés a címében jelzett másik témakört, a mesét orális hagyományként, prózapoétikai és kommunikációelméleti szempontból vizsgálja, így az ezzel érintkező metafora sem mint trópus, retorikai elem érdekes, hanem átviteli viszonyként inkább olyan kapcsolat, amelyben a figurativitás közege a kulturális kontextus részeként kialakuló szövegtér, egy nyelvi úton megképzett, interpretatív módon befogadott narratívum. Király Jenő Mozifolklór és kameratöltötoll címü, a populáris filmkultúra elméletével foglalkozó könyvében szintén a kommunikációs folyamatban betöltött szerepe felöl közelít a mítoszhoz és a meséhez. Egyenesen úgy fogalmaz, hogy: „az újra megtalált egyszerű formák jelentették az új kommunikációs forma, az új mủvészet első vívmányát". ${ }^{15}$ A fenti kérdéskör természetesen gazdagítható, hiszen többek között éppen Király Jenő filmszemiotikai vizsgálatai hívták fel a figyelmet egy viszonylag új területre a filmi metafora valamint a metaforikusság jelenlétének kérdésére a filmmüvészetben. ${ }^{16}$

Ha mindez így van - márpedig az utóbbi évtizedek e témával kapcsolatos kutatási nyilvánvalóvá tették - nagyobb jelentőséggel kell bírnia a metaforikusság jelenségének az irodalomtudományban annál, hogy túlburjánzó trópusnak, netalán egy-egy időszak vagy szövegtípus meghatározó jellemzőjének tekintsék. ${ }^{17}$

DRAAISMA: Metaforamasina. (Az emlékezet egyik lehetséges története.) Typotex, h. n., 2002.; KöVECSES Zoltán könyvében a metafora kognitív nyelvészeti megközelítése új szempontokat adhat olyan nyelvi jelenségek megítéléséhez, mint például a poliszémia vagy a jelentés változása. Ezzel összefüggésben hozzájárulhat a metaforikus jelentés kialakulásának kérdéséhez is. Vö. Uö.: A metafora. (Gyakorlati bevezetés a kognitív metaforaelméletbe.) Ford.: Várhelyi Gabriella. Typotex, Bp., 2005.

${ }^{15}$ KIRÁLY Jenő: Mozifolklór és kameratöltőtoll. (A populáris filmkultúra elméletéhez.) Magyar Filmtudományi Intézet és Filmarchivum, Bp., 1983. 143.

${ }^{16}$ Ezzel összefüggésben lásd pl. BíRó Yvette: A hetedik müvészet. Osiris. Bp., 1998. 18-22.; vagy Francesco CASETTI könyvének például a filmnyelv elemeivel, természetével foglalkozó részében filmretorikának nevezett jelenséget. $=$ Uö.: Filmelméletek 1945-1990. Osiris, Bp., 1998. 59-74.

${ }^{17}$ Figyelemre méltó, hogy míg a metaforával foglalkozó szakirodalom könyvtárnyi, nem számítva az utóbbi évtizedben egyéb humán tudományterületeken tapasztalható reneszánszát, addig a metaforikus prózát tárgyaló szövegértelmezések a mai napig kis számban olvashatók, inkább kortárs irodalmi szövegeket, 
A dolgozat legfőbb célkitüzése pontosan az, hogy a témát érintő szerteágazó elméleti kutatások figyelembevételével olyan szövegszerü olvasatokat adjon, melyek során belátható: a metaforikusság jelensége a prózapoétikában nem korszak-, münem- vagy szövegtípus-függő. Legfeljebb más-más módon, de egyaránt meghatározó jelleggel számolhatunk vele az egyes irodalmi alkotásokban. Nem meglepő, hogy a korábban kanonizálódott szerzők irodalomtörténeti helyének, jelentőségének megváltoztatását a metaforikus értelmezés, a szöveg tropológiai olvasata eredményezheti. ${ }^{18}$

A dolgozat második fejezete ezért a metaforikus próza jellemzőit tárgyalja a századforduló elbeszélőinél, ahol is „olyan prózai fragmentumokra bukkanunk, melyek nem történetelvüek, hanem a szövegszerü jelleget hangsúlyozzák" ${ }^{19}$ Itt elsősorban Csáth Géza és Szini Gyula novellisztikáját vizsgálva kitünik, hogy a szöveg metaforikussága a mese müfaji jegyeivel, a mesével mint narratív formával szoros összefüggésben kínál egyfajta alternatívát, mondjuk az anekdotikus elbeszélöi hagyományhoz képest. Az említett szerzők életművének részletes áttekintésére, teljes körü filológiai feldolgozására ehelyütt természetesen nincs mód. Az itt szereplö szövegközpontú olvasatok leginkább azt a tényt kívánták jelezni, hogy egy korábbi időszak elbeszélői törekvései, az alapvetően más szempontokat mozgató kanonizációjuktól függetlenül is tartogatnak meglepetéseket a metaforikus prózamodell szempontjából. A novellaíró Csáth Gézáról szólva figyelmeztet Dobos István még 1987-ben arra, hogy „a mese nemcsak fabula-alkotó elem. Másodlagos, metaforikus jelentést sürít magába, s ennek révén a motivációs rendszerben is szerepet kap. $" 20$

Ebben a megközelítésben a mese nem helyettesíthető egyszerüen a történetmondással, és nem utalható például a gyermekirodalom körébe, mivel műfaji jellemzői, hagyománytörténeti és beszédmódbeli sajátosságai nagyban befolyásolják a vele kapcsolatba lépő (kis)próza-formák megítélését is. A disszertáció értelmezései sem az esetleges mesemotívumok feltérképezésére irányulnak, sokkal inkább a lehető legtágabban értelmezett mese fogalmának beépítésére tesznek kísérletet az egy-egy szöveg, esetenként életmű egészére kiterjedő újraolvasási javaslataikkal, kísérleteikkel. Ebben pedig leginkább

esetenként világirodalmi alkotásokat érintenek. Vö. például HORVÁTH Kornélia - SzITÁR Katalin (szerk.): Szó - elbeszélés - metafora. (Műelemzések a XX. századi magyar próza köréből.) Kijárat, Bp., 2003.

${ }^{18}$ Vö. például: KelEMEN Pál: Metaforikus konstrukciók és olvasói szerepek Adalbert Stifter Bergkristall cimü elbeszélésében. In: JÓZAN Ildikó - KulcsÁr SZABÓ Ernő - SZEGEDY-MASZÁK Mihály (szerk.): $A z$ elbeszélés módozatai. Osiris. Bp., 2003. 147-172.; vagy Uö.: Útban a monológhoz? Elbeszélés és metafora Thomas Bernhardnál. In: Ua. 367-395.

${ }^{19}$ THOMKA Beáta: Beszél egy hang. (Elbeszélők, poétikák.) Kijárat, Bp., 2001. 12.

20 Dobos István: Racionalitás és misztikum. (A novellaíró Csáth.) In: DÉR Zoltán (szerk.): Emlékkönyv. (Csáth Géza születésnapjának századik évfordulójára.) Életjel, Szabadka, 1987. 120-121. 
az utóbbi évtizedek elméleti kutatásainak eredményeit figyelembe véve: a mese prózapoétikai és kommunikációelméleti vonatkozásait érintő interpretációs vonulatokra támaszkodnak.

Az értekezés harmadik részében a látszólag ötletszerüen kiválasztott, más-más időszakból származó korpuszok vizsgálata voltaképpen azt hivatott alátámasztani, hogy a metaforikus prózaszerveződés nem kizárólag néhány kitüntetett, ekként aposztrofált szöveg sajátja, ${ }^{21}$ vagy esetleg a mai magyar irodalom egyik ,új csapásiránya”. A metaforikus prózajelenségeket vizsgáló minimális arányú szövegértelmezés ellenére, különösen figyelemreméltó, hogy az e témát érintő korai kezdeményezések a nemzetközi fejleményekkel egy időben, az irodalmi interpretációval szoros összefüggésben érintették a metaforikusság kérdését. ${ }^{22}$

A dolgozat harmadik fejezetének egymás mellé kerülő értelmezései éppen ezért azt hivatottak példázni, hogy néhány mai, alapvetően eltérő poétikájú szöveg esetében is uralkodó jelenség lehet a metaforikusság, mely mint szövegszervező eljárás a már kanonizálódott szerzők, meggyökeresedett szövegértelmezések továbbgondolását, újraolvasását szintén elősegítheti. Ekként például Hajnóczy Péter, Mészöly Miklós, Nádas Péter és Parti Nagy Lajos, Garaczi László vagy épp Kukorelly Endre prózájának értésmódját. A mai magyar irodalomban, reprezentatív módon, a metaforikus szövegalakítás nemegyszer a testfelület megnyitása, a nyelvi megtestesülések hasításai, hasadásai metszésvonalán megnyíló müködésmód. A metafora eme túlburjánzó virágzása során maga is szóvirág lett, meta-metaforáktól hemzseg a rét, de hát miként a retorika megannyi virága, a napraforgó is ,a metafora alatt áll...”. ${ }^{23}$ A metafora mesekertje szókapcsolatban a kert, akárcsak a hegy kifejezés a legtöbb kultúrában ősi metaforáknak számítanak. ${ }^{24}$ A varázsló kertjének egzotikus virágai között, e virágrengetegben tehát ott a metafora is, legyen az a fejét ide-oda fordító napraforgó, vagy könnyedén lengedező szóvirág.

\footnotetext{
${ }^{21}$ Ilyen például Konrád György Városalapító címủ regénye, amely Thomka Beáta értelmezése nyomán A metaforikus próza egyik alapvető szövegeként kanonizálódott. Vö. THOMKA Beáta: Metaforikus folyamatok a regényben. $=$ Uő.: Narráció és reflexió. Forum. Újvidék, 1980. 39-48.

${ }^{22}$ Lásd Thomka Beátának az 1980-as, Narráció és reflexió címü kötetének e témát érintő írásait; SzegedyMaszák Mihály szintén ekkori könyvének (,A regény, amint írja önmagát”) Kosztolányi és Krúdy értelmezéseit; valamint Kulcsár Szabó Ernő: Metaforikusság és elbeszélés címü, 80-as évek elején készült tanulmányát; illetve Odorics Ferenc e témában szintén alapvető fontosságú, Miképpen értünk meg metaforikus szövegeket? címen 1985-ben, a Literaturában megjelent írását. Pontos bibliográfiai adatokkal együtt lásd: III. Nyelvcsap(ol)ások - a metaforikus próza változatai a mai magyar irodalomban, 117. oldal

23 Jacques DERRIDA: A retorika virágai: a napraforgó, i. m. 32.

24 Vö. GÉCZI János: A tudása forrása: a kert. Magyar pedagógia, 1999/3. 221-243.
} 
A Metaforikus prózaváltozatok a modernitás poétikájában cím a mai irodalomértési gyakorlat legkedveltebb kifejezéseit az említett összefüggésrendszerben helyezi el. A modernitás így már nem pusztán korszakmegjelölés, az irodalom 20. század első felében keletkezett alkotásainak idő- és korszakhatároló elnevezése, hanem olyan müvészeti, poétikai szemlélet jelzője, amely törekvéseit tekintve „modern”-nek nevezhető. Az újszerü, paradigmaváltó, a irodalmi hagyományt átértelmező megnyilvánulások sora, amelyek (kiszélesítve, és a korszakhatároló jelleget elbizonytalanítva) a mai értelmezői perspektívából egyaránt jellemezhetik a romantikától a klasszikus modernségen át a Nyugat egymást követő nemzedékeiig nyúló alkotói törekvéseket, s föleg azokat, amelyek előeseményként, hagyományként, egyes mai, kortárs irodalmi, textuális eljárások hátterében is kimutathatók, érzékelhetők.

Ebben a nyelvi, retorikai alapú, poétikai eljárásokat összevető megközelítésben a szigorú műfaji összefüggéseken, kormeghatározó jegyeken és stílusjellemzőkön túllépve az elbeszélő próza figuratív megoldásai, eljárásai vagyis a metaforikusság szempontjából rendezhetők újra és vonhatók termékeny párbeszédbe egymással a különböző időszakok alkotásai. A hagyományos, kronologikus és fejlödéselvü irodalomtörténet helyét az utóbbi évtizedekben egyre inkább az ilyen, mai ételmezői perspektívából relevánsnak tartott szempont alapján szelektáló, újrarendező irodalomszemlélet látszik átvenni. ${ }^{25}$

Mindez persze magyarázható az elmúlt évtizedekben lezajló, e témát széleskörüen érintő teoretikus felismerések beérésével, az elvont, elméleti alapvetések értelmezői, irodalomértési gyakorlattá válásával. Kulcsár Szabó Ernő például 1993-as írásában éppen az irodalmi modernség kategóriájának tárgyalásakor hivatkozik erre az európai gondolkodásban lezajló tudományos paradigmaváltásra. ${ }^{26}$ Nem véletlen, hogy az e szöveget tartalmazó három évvel későbbi könyvében, már ezeknek a felismeréseknek az értelmezői gyakorlatba emelésével vállalkozik az irodalmi modernség formációinak felvázolására; többek között Kassák, Móricz, Márai, Tersánszky szövegeinek újraszituálására a „nyelv mint alkotótárs” tapasztalata jegyében.

Jelen dolgozat - a poétika fogalmának újragondolását sürgető Horváth Kornélia

\footnotetext{
${ }^{25}$ Lásd a Szegedy-Maszák Mihály által szerk. „új spenót” (A magyar irodalom történetei. 1-3. Főszerk.: SzEGEDY-MASZÁK Mihály. 3 kötet, Gondolat, Bp., 2007.), vagy ennek elektronikus változatát, a „villanyspenótot" (http://www.villanyspenot.hu/), és ennek visszhangját a kritikai diszkurzusban.

26 „A nyolcvanas években Európában lényegében ebből a pozícióból [ti. Hans Bertensnek a modern posztmodern dichotómiája nyomán vázolt új interpretációs távlat felöl] indult meg az egész modernség újraértelmezésének folyamata olyan - korábban kevesebb figyelemre méltatott - szerzők »felfedezésével«, akik a dolgok rendjének nyelvi, diszkurzusbeli státusváltozásaival hozták összefüggésbe a történeti változások természetét (Foucault, Lacan, Derrida, Blimenberg és mások).” Vö. KULCSÁR SzABÓ Ernő: Az irodalmi modernség integrativ történeti értelmezhetösége. = Uő.: Beszédmód és horizont. (Formációk az irodalmi modernségben.) Argumentum, Bp., 1996. 10.
} 
felvetéssel összhangban ${ }^{27}$ - a poétikának azt a szemléletét követi, ,amelynek esetén a müalkotás-szöveget nem képződményként, nem kész produktumként, hanem dinamikus nyelvi alakulásfolyamatként” értelmezi, ez esetben pedig természetes, hogy „ez a mü és irodalomtörténeti folyamat viszonyának elgondolására nézve is következményekkel jár”. ${ }^{28}$ E helyütt természetesen nincs mód mindezen változások átfogó bemutatására, így mindössze a fogalomhasználat irányultságának jelzéseképpen a korábbi irodalmi kategóriákat, (kor)stílusjegyeket újragondoló szemlélet létjogosultsága miatt releváns e kérdéskör.

A kutatás elsősorban arra irányul, hogy bemutassa a trópusok elbeszéléstechnikai, narratológiai összefüggéseit, elsősorban a metaforikusság szövegszerü megjelenését a prózában, elbeszélő szövegekben.

A századforduló irodalmában az egyszerü formák, a mese, mítosz stb. és az elbeszélés változatainak találkozása hatására, kölcsönös irodalmi és kulturális összefüggésrendszerük mozgásterében bontakozott ki a szövegalakítás metaforikussága, ugyanakkor a mai irodalmi szövegek egy része a szubjektum megragadhatatlanságának önértelmező gesztusaként, a testiség határ- és léttapasztalatának gyakori kifejezési formájaként téved a trópusok területére.

E fent említett, a poétika és a narratológia hasonló kérdésfelvetéseit mozgató elméleti háttér közvetítésével összekapcsolhatónak tünik a különböző időszakokban és szerzőknél más-más módon, ám egyaránt hangsúlyosan jelentkező problémakör: a test megszövegezését, továbbá a nyelv megtestesülését kiaknázó nyelvhasználati formák kultúrszemiotikai, prózapoétikai és tropológiai aspektusa, valamint ezek művészetbölcseleti kontextusa.

\footnotetext{
${ }^{27}$ Mindezzel, illetve a poétikai fogalmának tudománytörténeti átalakulásával kapcsolatba lásd: HoRvÁTH Kornélia: A poétika fogalma a modern irodalomtudományi diskurzusban. In: RADVÁNSZKY Anikó (szerk.): „Ember lenni mindég, minden körülményben” - tanulmányok Kiczenko Judit születésnapja alkalmából. PPKE BTK, (Pázmány irodalmi mühely), Piliscsaba, 2008. 184-207.

${ }^{28}$ HORVÁTH Kornélia: i. m. 207.
} 


\section{I. „,..árnyék rajtunk és bennünk" - mese, metafora, elbeszélés}

\begin{abstract}
„A mese talán a legcsillogóbb "árnyék" rajtunk és bennünk. Valami, ami megfoghatatlanabbul valóságosabb minden másnál, ami kitelik belölünk."
\end{abstract}

Mészöly Miklós ${ }^{29}$

Az utóbbi évtizedek irodalomelméleti kutatásaival párhuzamosan lezajló újraolvasási folyamatnak köszönhetően - a különböző résztanulmányokat, kismonográfiákat tekintve jelentős mértékben módosultak a korábban kijelölt korszakhatárokról, stílusirányzatokról és müfaji kategóriákról alkotott elképzelések. ${ }^{30}$

$\mathrm{Az}$ irodalomtudomány kölcsönhatásban más társadalomtudományokkal mindenekelőtt a filozófiával, nyelvészettel, szociológiával, antropológiával, szemiotikával és esztétikával - az egyes fogalmakat, stilisztikai jelenségeket, nyelvi-retorikai kategóriákat egyre kiterjedtebb kontextusban, szerteágazóbb szempontrendszer viszonylatában tárgyalja. ${ }^{31}$ A diszciplináris határok fellazulásával beszélhet a történelemtudomány kapcsán többek között Hayden White az irodalmi müfaji mintákat követő cselekményesítésről, melyből egyenesen következik az A történelem terhe címü könyvének sokat vitatott megállapítása, mely szerint csak a tények felhasználásával készített, ilyen-olyan műfajú és stílusú elbeszéléseket nevezzük történelmi eseményeknek, $\mathrm{s}$ valójában a történelem sem más, mint fikció. ${ }^{32}$

A múlt nyomait helyettesítő nyelvi alakzatok, a hagyományos elbeszélő struktúrákat felváltó textuális eljárások vizsgálatával a historiográfia, ${ }^{33}$ valamint egyéb társtudományok poétikai tapasztalatait hasznosítva az irodalomtudomány is újabb szempontokkal gazdagodott, és ezek fényében az elmúlt minimum száz év irodalmi alkotásai teljesen más megvilágításba helyeződnek.

\footnotetext{
${ }^{29}$ Vö. Mészöly Miklós mühelyvallomása. (Az íróval Szörényi László beszélgetett. Elhangzott 1985. dec. 2-án a Magyar Rádió Mindennapi irodalmunk címü adásában.) Vigília, 1986/3. 231-232.

${ }^{30}$ Lásd a Ráció Kiadó sorozatát (pl.: BóNUS Tibor, KULCSÁR-SZABÓ Zoltán, SiMON Attila (szerk.): $A z$ olvasás rejtekútjai. (Müfajiság, kulturális emlékezet és medialitás a 20. századi magyar irodalomtudományban.) Ráció, Bp., 2007., vagy akár a Szegedy-Maszák Mihály föszerkesztésében készült $A$ magyar irodalom történetei köteteit.

${ }^{31}$ Northrop FRYE: A metafora táguló világa című írásában ezért is állapítja meg, hogy „Előbb vagy utóbb az irodalomkritika, a filozófia és a legtöbb társadalomtudomány iránya magában a nyelvnek a tanulmányozásában találkozik össze. A nyelv jellemzői egyértelmüen lényeges nyomravezetők mindennek a természetéhez, ami csak nyelvből épül fel." (Ford. Máthé Andrea) http://epa.oszk.hu/00000/00002/00024/ frye.html (2008. 08. 13.) Vö. Northrop FrYE: Myth and Metaphor. Robert D. Denham (ed.): Selected Essays 1974-1988. University Press of Virginia, 1990.

${ }^{32}$ Vö. Hayden WhITE: A történelem terhe. Ford.: Berényi Gábor. Osiris, Bp., 1997.

${ }^{33}$ Vö. THOMKA Beáta: Elbeszélés, poétika, historiográfia. In: ÁRMEÁN Orsolya - FrIED István - ODORICS Ferenc (szerk.): Irodalomelmélet az ezredvégen. Gondolat - Pompeji, Bp., - Szeged, 2002. 134-147.
} 
A retorikai olvasás jelenségével összefüggésben, ${ }^{34}$ a modernitás poétikája alapján létrejövő szövegtér egyaránt tartalmazhatja a századforduló prózairodalmának alkotásait és a kortárs, illetve a legújabb magyar irodalom jó néhány szövegét. ${ }^{35} \mathrm{Az}$ irodalomtörténetről ily módon a hatástörténetre helyeződik a hangsúly, a korpusz pedig kiegészül a korabeli kritika és a kortárs elméletek szekunder szöveganyagával, melyek együttlátása számos, ez idáig feldolgozatlan szempontot eredményez. Hiszen a hagyomány részét képező későbbi irodalmi alkotások nem csak újraírják előszövegeiket, elbeszélői mintáikat, hanem a hatástörténet jaussi dialogikus felfogásában a hagyomány újraolvasását, más értelmezői pozícióból történő befogadását is elősegítik.

\section{Metafora-kontextusok: metafora a prózapoétikában}

Az utóbbi évtizedekben számos lépés történt afelé, hogy a korábban hagyományos retorika részeként elgondolt trópusok ne pusztán a meggyőzés művészetét szolgáló elemek vagy díszítőeszközök gyanánt említődjenek, sokkal inkább a szövegek értelmezését befolyásoló jelentéstermelő struktúrák részeként. ${ }^{36}$ A klasszikus retorikák alakzat-tipológiája vagy a nyelvészeti, stilisztikai szempontokat követő tetemes mennyiségü szakirodalom mellett persze komoly elméleti bázist képviselnek azok az írások, melyek a nyelv figuravitását nyomatékosítva szemiotikai, filozófiai és egyéb szerteágazó szempontokhoz kapcsolják a trópusok vizsgálatát. ${ }^{37}$

\footnotetext{
${ }^{34}$ De Mannak a 70-es évek végén írott, de a magyar irodalomtudományos gondolkodásba elsősorban a magyar nyelvü megjelenését követően számottevő, Proust és Rousseau-elemzései nyomán egy olyan olvasási folyamat bontakozik ki, melyben „a retorika trópus és meggyőzés, vagy [...] kognitív és performatív nyelv bomlasztó összefonódásaként jelenik meg.” Vö. Paul DE MAN: Az olvasás allegóriái. (Figurális nyelv Rousseau, Nietzsche, Rilke és Proust müveiben.) Ford.: Fogarasi György. Ictus és JATE Irodalomelmélet Csoport, Szeged, 1999. [A továbbiakban DE MAN: i. m.] Ennek újabb kiadása: UA. Magvető, Bp., 2006. Ezzel kapcsolatban részletesebben lásd: KulCSÁR-SZABÓ Zoltán: Figuráció és defiguráció. (A tropológia koncepciója Paul de Mannál.) = Uö.: Tetten érhetetlen szavak. (Nyelv és történelem Paul de Mannál.) Ráció, Bp., 2007. 105-135.; E folyamathoz kapcsolódott a szegedi de-KON csoport müködése, és a Retorikai füzetek elnevezésü könyvsorozata. (FüzI Izabella - ODORICs Ferenc (szerk.): Figurák. Gondolat - Pompeji, Bp., - Szeged, 2004. Ennek Az olvasás új lehetöségeiként aposztrofált jelenségnek az összefoglalását és a retorikai olvasás fogalmát lásd: DoBos István: $A z$ irodalomértés formái. Csokonai, Debrecen, 2002. 44-47.

${ }^{35}$ A Ráció Kiadó több kötete aktuális irodalomelméleti problémák, kategóriák felöl kísérlik meg újraolvasni a magyar irodalom szerzőit, a századelőtől a 20. századi modernségen át a mai elbeszélői törekvésekig. Miközben ,a leírást összekapcsolja az adott korszak önreflexiójával, majd szembesíti az elkövetkező évszázad elméleti és filológiai visszatekintő számbavételével." Vö. HANSÁGI Ágnes, HERMANN Zoltán, HORVÁTH Csaba, SzITÁR Katalin, TÖRÖK Lajos (szerk.): Egy csonk maradhat" (Tanulmányok az 1920-as évek magyar irodalmáról.) Ráció, 2004. 7.

${ }^{36}$ Vö. BEZECZKY Gábor írásával és a Helikon tematikus metafora-számának e címen összefoglalt jellemzőivel. Uö.: A jelentésteremtö metafora. Helikon 1990/4, 379-389.

${ }^{37}$ Ezzel kapcsolatban lásd pl. Gilles Deleuz: Cinema 2. (The Time-Image.) Trans.: Hugh Tomlinson, Robert Galeta. University of Minnesota Press, Minneapolis, 1989., illetve többek között Antal Éva: Túl az irónián. (Retorikus olvasatok.) Kijárat, Bp., 2007.
} 
Anélkül, hogy bármilyen tudománytörténetileg igazolható, átfogó jellegü tendenciózusság felvázolását kísérelné meg a dolgozat, annyi talán megállapítható, hogy a klasszikus retorikák alakzat-tipológiától eltávolodó strukturalizmust követő időszakban, mind az angolszász metaforaértési tendenciában, mind pedig a francia teoretikusok munkáiban kezdetben komoly hangsúlyt kap ez a témával járó interdiszciplinaritás. ${ }^{38} \mathrm{~A}$ trópus fogalmának minimális változása mellett néhány retorikai jelenség megítélésében (és itt, ha nem is kitüntetett, de mindvégig számottevő a metaforikusságé) komoly szerepet kap az a megközelítés, mely e jelenséget a szöveges, nyelvi létmódhoz szorosan hozzátartozóként kezeli. ${ }^{39}$

Abádi Nagy Zoltán egyik írásában a trópust egyenesen a narrativitás alapvető tényezőjének, a narrátori viszony megnyilvánulási formájának tekinti. „A trópus a szépirodalmi elbeszélés szövegszintjén jelenik meg, vagyis narrátori funkció, és akként nem »csupán« cselekmény-, szöveg-, szövegvilágképző szemantikai-szemiotikai rendszer, majd (befogadói nézetből) hermeneutikai iránytü, jelentésképző átviteli eszköz(rendszer) történet és jelentés között, hanem az elbeszélés elbeszélhetőségének fontos eszköze, gyakorta forrása; röviden szólva: narrativitás. ${ }^{40}$ Ezeknek a belátásoknak fényében a metaforaelméletek korábbi alapvető felvetései és megközelítési módja is továbbgondolhatónak tűnnek.

Elegendő itt Paul Ricoeur alapvető könyvének korántsem új keletű észrevételeit idézni. A metafora és a diskurzus szemantikájáról szólva abból indul ki, hogy a metaforikus mondat vizsgálata „nem szükíthető le a lexikai egységek szemantikájára” ${ }^{41}$ A szemiotikai és szemantikai megközelítés szétválása nyomán a szerző szerint például I. A. Richards „egész retorikai vállalkozása arra irányul, hogy - a szó ellenében - visszaállítsa a diskurzus jogát”. A ,jelentés kontextuális tana” alapján Richards szakít a klasszikus retorikák tulajdonképpeni jelentés-átvitt jelentés szembeállításával, és - ahogyan Ricoeur fogalmaz - „,itt most már nem a szavak egyszerü eltolódásáról, hanem gondolatok közötti

38 Domonkos Péter: Nyelvfilozófia, pszichológia és irodalomtudomány Derrida Mémoires-jában. Világosság, 2006/2. 3-9.

39 Lásd pl. SzILVÁssy Orsolya: A lehatárolt interpretáció. (Metaforikus terek és értelmezési modellek $A$ Foucault-ingában.) Világosság, 2007/2-3. 87-100.

${ }^{40}$ ABÁDI NAGY Zoltán: A trópus mint kulturalizációs narrativitás. In: KovÁcs Árpád (szerk.): A regény és a trópusok. (Tanulmányok. A második veszprémi regénykollokvium.) Diszkurzívák, Bp., 2007. 7.

${ }^{41}$ Paul Ricoeur: Az élö metafora. Ford.: Földes Györgyi. Osiris, Bp., 2006. 103. Mindezek tudománytörténeti és nyelvfilozófiai vetületének alapos tárgyalását lásd: SEREGI Tamás: Paul Ricoeur cselekvésontológiája. Világosság, 2007/1. 43-64. „Ricoeur két fronton is felveszi a harcot korának strukturalizmusa ellen, amikor a metafora témájához nyúl: az egyik a helyettesítés, a másik pedig a „térbeliség” területe. A helyettesítés elleni vehemens támadás természetesen nem kizárólag a strukturalizmusnak szól: a retorikai hagyományban uralkodó szóalapú metaforaelmélet egészére kiterjed.” Uö.: i. m. 55. 
cserekereskedelemről, azaz kontextusok közötti tranzakcióról beszélhetünk inkább". ${ }^{42}$ A metafora így Richardsnál a két különböző dologhoz kapcsolódó, egyszerre aktivizált gondolatot köti össze egy olyan kifejezésen belül, amelynek jelentése ezek interakciójából következik. Ricoeur ezzel összefüggésben az ismert richardsi tenor („,tartalom”) és vehicle („,hordozó”) terminusok használatakor arra is rámutat: „végképp kizárt, hogy az alakzaton kívül is »tartalomról« beszélhessünk, illetve hogy a »hordozót« egyfajta hozzáértett díszítésnek tekintsük: a metafora a »tartalom« és »hordozó« egyidejü jelenlétéből és a kettő interakciójából születik”. A metafora tehát a „két félből”, a tagokból álló egész, az odaértett fogalom és a „hordozó”, amelynek jele a „tartalomra” utal, együtt alkotják az alakzatot. A metafora interakciós elméletét megalapozó szemlélet nyomán, ${ }^{43}$ mintegy ezt kitágítva, a kontextus fontossága, a trópusok közötti viszony- és mozgásrendszerben a szövegterek egymásba épülése, dialogikus viszonya áll a megközelítések középpontjában.

Metaforizáció ebben az összefüggésrendszerben, az a folyamat lehet, (nem függetlenítve a szerzői intenciótól, de elsősorban a befogadás viszonylatában értékelve), amelynek során egy az alapvető trópusokból mint formális elemekből szerveződő metaforikus szerkezet kialakul, és a szövegstruktúrába aktívan bekapcsolódva befolyásolja ennek megértését. ${ }^{44}$ Folyamat annyiban, amennyiben az egyes szövegegységekben előforduló trópusoknak nem eleve és elszigetelten tulajdonítunk valamiféle jelentést, hanem az az értelmezés során, a befogadó és a szöveg közti kölcsönös értelmezői viszonyban képződik meg. ${ }^{45}$

Metaforikus szerkezetnek ${ }^{46}$ tekinthető minden olyan szövegegység, amely tropikus szerveződésü, vagy akként értelmezhető, vagyis a jelentéstulajdonítás az izotópia

\footnotetext{
${ }^{42}$ Uö. i. m. 122-123.

${ }^{43}$ Lásd erről pl. THOMKA Beáta: Metafora, interpretáció, teória. Literatura, 1994/2. 204-212.

${ }^{44}$ A metaforát nem elszigetelten vizsgálva, önálló trópusként, retorikai elemként, hanem mint metaforikus viszony, kapcsolat, melyben a metaforikusnak szövegelem recepciójakor távoli nyelvi elemek interakciója révén teremtődő új jelentésekre helyeződik a hangsúly. Többek között Paul Ricoeur, Bezeczky Gábor, Benyovszky Krisztián is a trópusként értett metafora és a metaforizáció mint akár az egész szövegre kiterjedő szemantikai művelet közti kapcsolat jelentőségére figyelmeztetnek. Vö. BENYOVSZKY Krisztián: Az elbeszélt metafora. Világosság, 2006/8-9-10. 137-144. BEZECZKY: i. m. 206-209. RICOEUR: i. m. 261.

${ }^{45}$ Hasonlóan ahhoz, ahogy ,a szöveg környezeti és helyi aspektusai között fennálló kölcsönös viszony” alapján látja a metafora és a szöveg kapcsolatát Paul Ricoeur. „A metafora mint egy elkülöníthető szövegesemény magyarázata közremüködik az alkotás mint egész értelmezésében. Azt is mondhatjuk, hogy a szöveg mint egész értelmezése és az alkotás által előállított világ kitisztulása világítja meg a metaforák értelmezését..." Vö. Paul RiCOEUR: A metafora és a hermeneutika központi problémája. Ford.: Kovács Gábor. In: KovÁcs Árpád (szerk.): A regény és a trópusok, i. m. 415. [Az értelmezés megfelelőjeként utána zárójelben szereplő interpretáció-betoldásokat kihagytam a szövegből. B. S.]

${ }^{46}$ Fogalom korai előfordulását, meghatározását lásd pl.: SzEGEDY-MASZÁK Mihály: Metaforikus szerkezet Kosztolányi Caligula és Krúdy Utolsó szivar az Arabs szürkénél címü szövegében. = Uö.: „A regény, amint irja önmagát”.' i. m. 46-47, 56.
} 
törésekor ${ }^{47}$ vagy egymásba épülésekor fellépő értelmezői viszonyulást, interpretációs munkát igényel. A kérdés tehát adott esetben nem az, hogy valamely szövegrészben van-e metafora, metonímia stb. vagy nincs, hanem, hogy az olvasó - ezen trópusok minimális jellemzőit (hasonlóságon alapuló, érintkezéses stb. viszony) tekintve - mit ismer föl akként. Metaforizációról mint szövegszervező eljárásról tehát elsősorban nem a metaforaként értett szavak szövegbe kerülésekor beszélhetünk, hanem az ezek mintájára szerveződő szövegegységek esetében - legyenek ezek akár szókapcsolatnyiak, akár a mondat vagy nagyobb textuális egészre kiterjedők, - amelyek befogadásakor az említett trópusok az értelmezést tekintve ezzel inherens viszonyba kerülnek. ${ }^{48}$

Ezt az interpretációs eljárást követi de Man, amikor Szemiológia és retorika címü írásában egy Proust-szöveghely kapcsán a más-más szinten értelmezett trópusok egymáshoz való viszonyát vizsgálja a kijelentés állításértéke felől. (,,...kimutatható, hogy a szöveg nem azt teszi, amit prédikál. A szövegrész retorikai olvasata megmutatja, hogy a figurális gyakorlat és a metafigurális elmélet nem konvergálnak, s hogy a metafora metonímia feletti uralmának állítása metonimikus struktúráknak köszönheti saját meggyőzőerejét.”) Ezen megközelítésben egyértelmüen hiányosságként jelentkezik mutat rá lényegre törően de Man - „hogy a retorika mindig is megelégedett a szavak paradigmatikus szemléletével (miszerint a szavak helyettesítik egymást), anélkül, hogy rákérdezett volna szintagmatikus viszonyukra (a szavak egymáshoz való kapcsolatára).” Ahol ezek a szavak persze jelen esetben egyúttal trópusokként (is) müködnek, és így érthető a felvetés, hogy „lennie kell egy másik, az elsőt kiegészítő szemléletmódnak, melyben a metafora például nem helyettesítésként, hanem a kombináció sajátos típusaként határozódna meg". 49

A hangsúly tehát nem az elszigetelten kezelt egyes trópusok megjelenésén van, hanem az egymáshoz való viszonyukon, a szövegben egy tágabb kulturális és nyelvi közegben betöltött szerepükön. A kombinációnak mint alapvető szemlélet és gondolati sémának a tárgyalása nem szükíthető az irodalomtudományra. Kiály Jenő például a borzalom esztétikájáról, az „izommozi”, a vizuális (erő)szaknyelvről szólva jegyzi meg,

\footnotetext{
${ }^{47}$ VíGH Árpád: Retorikai kislexikon. = Uö.: Retorika és történelem. Gondolat, Bp., 1981. 513.

${ }^{48}$ A disszertáció, ezért részben támaszkodik arra a - 20. századi orosz nyelvfilozófia, elsősorban Alekszandr Potebnya és Olga Frejdenberg munkássága nyomán kialakuló - megközelítésre, melynek szellemében Horváth Kornélia vagy Szitár Katalin szövegeiben a szó és metafora kapcsolatát a szóelmélet alapjaira helyezi. E felfogással kapcsolatban lásd: KovÁcs Árpád (szerk., vál.): Poétika és nyelvelmélet. (Válogatás Alekszandr Potebnya, Alekszandr Veszelovszkij, Olga Frejdenberg elméleti müveiböl.) Diszkurzívák, Bp., 2002. Emellett természetesen több, a metaforikusság kitágított, kultúrákat és narratívákat átszövő jellegére épülö megközelítést is követ.

${ }^{49}$ DE MAN: Szemiológia és retorika. $=$ Uö.: i. m. 17-18.
} 
hogy az „erőszak és erotika kettős uralma a populáris mitológiákban a fantázia logikájának szükségszerűsége. Szelekció és kombináció, válogatás és összekapcsolás, destrukturálás és restrukturálás, rombolás és újjáálmodás hozzák létre, az érzéki képzelet anyagában tevékenykedve, a népszerü kultúra jellegzetes tematikáját. A két alapmüvelet, minden szellemi élet két elemi mozgásformája - szelekció és kombináció - képviselője a népszerű mítoszokban, szórakoztató műfajokban erőszak és erotika, halál és szerelem." ${ }^{, 0}$

A tágabb kulturális, hagyománytörténeti diskurzus kontextusát bevonó elképzelések esetében azonban sokszor, épp az figyelhető meg, hogy a szövegkörnyezetből kiszakított egyes szavak, metaforikusnak vélt kifejezések jelentéséhez igyekeznek eljutni. Monroe C. Beardsley A metaforikus csavar címü írásában hangsúlyozza, hogy „egy bizonyos metafora természete nem lehet teljességgel független az angol irodalom történetében elfoglalt helyétől. Mert annak, amit jelent vagy jelenthet egy adott időben, bizonyos mértékig függenie kell attól, hogy a szavak milyen más kontextusokban jelentek meg, és hogy milyen analóg vagy párhuzamos kifejezések léteznek a nyelvben." Ugyanakkor ezen felismerésével párhuzamosan a szövegkörnyezetéböl kiszakított egyes szavakat, szókapcsolatokat vizsgál („tövis”, „gonosz ember” „szeszélyes hold” stb.), és metaforikus jelentésük után kutatva az abszolút érvényűnek tekintett szó szerinti jelentéshez viszonyít. „Ha most elfordítjuk a figyelmünket a metaforába utalt tárgyakról - írja Beardsley -, és a szavaknak maguknak a jelentéseit vizsgáljuk, akkor a metafora metaforikusságát [...] valami olyan konfliktusban kell keresnünk, ami a szó szerinti kifejezésből hiányzik."51

A metaforikus szerkezetet alkotó trópusok szerveződéséről, és az ezekbe beépülő szavak jelentéséről magának a szerkezetnek egy nagyobb szövegegységhez való viszonyára helyezve a hangsúlyt (értve ezen az adott mü kontextusát, vagy irodalmi, kulturális hátterét, intertextuális szövegterét) a szó szerintiség kategóriája is elveszti elsődleges, viszonyító szerepét. ${ }^{52} \mathrm{Ez}$ a hangsúlyeltolódás számos interpretációs

\footnotetext{
${ }^{50}$ KIRÁLY Jenő: A borzalom esztétikája. (Izommozi.) Filmvilág, 1988/7. 25. [A kiemelés tőlem. B. S.]

${ }^{51}$ Monroe C. BEARDSLEY: A metaforikus csavar. Helikon, 1990/4. 412. Lásd: Paul Ricoeur ezzel kapcsolatos megállapításait és részben Beardsley elképzeléseivel polemizáló, a metaforikusságot a nyelvi interakciós hálózatok irányába kinyitó megállapítását. RICOEUR: i. m. 142-148. (Vö. „Én viszont inkább azt mondanám, hogy a metaforikus attribúció lényege nem más, mint egy olyan interakciós hálózat megalkotása, amely valamely kontextusból egy aktuális és egyedi kontextust teremt. A metafora, így egy több szemantikai mező metszéspontjánál létrejövő szemantikai esemény lesz.”)

${ }^{52}$ Ennek megfelelően a trópus - figura, és ezek jelzö értékü figurativ - tropikus kifejezések, ha nem is egymás szinonimáiként, de a szövegkörnyezethez igazodva, a szóismétlések kiküszöbölése miatt is egymással „összejátszva” felcserélhető viszonyban állnak a dolgozatban. A fogalomtörténetet és a klasszikus retorikák különbségtételét mellőzve inkább a trópus fogalmát a figura kontextusfüggő használata felé tágítva kísérli meg beemelni, elfogadva Füzi Izabella megállapítását miszerint „,a trópusok és figurák közti tiszta megkülönböztetés fenntartása nem lehetséges". Vö. Uö.: A figurák jelelmélete. In: FÜZI Izabella ODORICS Ferenc (szerk.): Figurák. Osiris - Pompeji, Bp., - Szeged, 2004. 9-41., különösen: 9-23.
} 
áthelyeződésre enged rálátni, melyben nem kizárólag az egyes elszigetelt jelentésegységek között létesül kapcsolat, hanem termékeny játékba vonható a szövegtérbe lépő értelmező is.

Paul de Man sokat idézett „köznapi” esetében arra mutat rá, hogy olykor a szó szerinti és a figuratív jelentés közötti viszony az értelmezés szempontjából sem egyirányú (a szószerintit újszerüen, izgalmasan elmondó metaforikus) és némelykor a „pusztán” szó szerinti legalább annyira zavarba ejtő, mint a tropikus. A felesége kérdésére „leegyszerüsítve” válaszoló Archie Bunker esete nemcsak arra enged következtetni, hogy „egyazon grammatikai szerkezet két olyan jelentést hoz létre, melyek kölcsönösen kizárják egymást: a szó szerinti jelentés arra a fogalomra (a különbségre) kérdez rá, amelynek létezését a figuratív jelentés tagadja”. De Man is - bár más szempontból - utal a figurális jelentésképződés kontextuális kezelésére. „Nem egyszerüen arról van szó, hogy két jelentés létezik, egy szó szerinti és egy figurális, s hogy nekünk kell eldöntenünk, e konkrét szituációban melyik a helyes. A zavart csakis egy szövegen kívüli szándék közbelépése oszlathatja el, például az, hogy Archie Bunker „ráncba szedi” a feleségét. Ez a „szövegen kívüli” szint persze a korábbi párbeszédhez képest külső, de adott esetben a „ráncba szedés” ugyanúgy nyelvi úton zajlik, mint a probléma kialakulása (pl.: „nem érdekel az okoskodásod"), vagy akár egy korábbi kontextuálisan ide kapcsolható szövegrész felidézésével (pl.: „tudod, hogy feldühít a lényegtelen dolgok részletezése”). ${ }^{53}$

A szó szerintinek nevezhető leggyakoribb alkalmazás helyére sok esetben egy kevésbé „,bejáratott” kerül, ami nem feltétlenül metafora, de a szövegkörnyezet stb. következtében az aktuális szöveg müködése ezzel párhuzamos, hasonló szerveződést mutathat. Derrida megfogalmazásában ez a jelenség a metafora „elrejt(őz)ése”, mely során az általa felidézett hasonlósági relációra, vagyis metaforikus szövegmúködésre kerül a hangsúly. „Vannak olyan kifejezések, - írja - amelyek sem nem homonimák, sem nem metaforák, még csak nem is szó szerinti (outé kuriós) értelemben használatosak, [...]. Ezek a kifejezések a metafora alatt állnak. A metafora tulajdonképpen nem jöhet létre anélkül, hogy az általa létrehozott hasonlóság (dia ten homoloteta) folytán a jelentett dologról (to semninomenon) bizonyos ismerete ne lenne, mivel mindig, amikor metaforát használunk, célunk pontosan a hasonlóság megragadása." ${ }^{, 54}$ A Nap metaforát vizsgálva (mely szerinte egyben a metafora metaforája is, vagyis meta-metafora) Derrida e jelenség konkrét

\footnotetext{
${ }^{53}$ DE MAN: Szemiológia és retorika. $=$ UÖ.: i. m. 21-22. Ezzel kapcsolatban lásd még: DARABOS Enikő: $A$ trópusok hatalma. In: ÁRMEÁN Orsolya - ODORICS Ferenc (szerk.): Határon. Pompeji, Kolozsvár Szeged, 43-58.

${ }^{54}$ Jacques DERRIDA: A retorika virágai: a napraforgó, i. m. 33.
} 
metaforaként történő tárgyalása helyett - nem függetlenül ennek sem a leggyakoribb megjelenésétől (égbolt) sem „szöveghelyétől” (Arisztotelész) - maga is a metaforikusságot mint egy viszonyt leíró jellemzőt tárgyalja. ,...a tulajdonképpeni Nap, az érzékelhető Nap nemcsak azért szolgál rossz ismeretekkel, mert metaforái rosszak, hanem mert ő egyszerüen metaforikus. [...], ... a Nap a diskurzusában saját magaként soha nincs jelen, mondja Arisztotelész. Mindig, amikor metafora van, Napnak is kell lennie valahol, és mindig, amikor Nap van, útjára indul a metafora.,

Az ekként értett metaforikusság az egyes trópusok ilyen vagy olyan jelentésének megszállott keresése helyett a szövegmüködésre és a jelentésképződésre mutat, vagy éppen világít rá. Az írott szöveg ezen jellemzőinek az értelmezésben betöltött, a jelentés pluralitását előidéző szerepe az interpretáció során számos olyan tulajdonítást eredményezhet, melyek a szerzői intenciótól függetlenek, eleve nem kódolt nyelvi eredettel bírnak. Ekként érthető De Man azon elragadtatott megjegyzése, miszerint: „én habozás nélkül magával az irodalommal azonosítanám a nyelv retorikai, figurális potenciálját”. ${ }^{56}$

Ennek ellenére nem érdemes figyelmen kívül hagyni a nem a legszükebb értelemben vett szépirodalom körébe utalható, szintén a metaforikus szerkezetek mintájára szerveződő, más nyelvi struktúrákat sem. Bevonhatónak tünnek a kérdéskörbe más műalkotás-formák is, akár a képzőművészet, akár a filmművészet területéről. ${ }^{57}$ Vagyis bármely - egy bizonyos értelmezői hozzáállásból - szövegként elkönyvelt nyelvileg (is) artikulálódó alkotás esetében figyelembe vehető a metaforizáció jelenléte. Jurij Lotman $A$ retorika címü tanulmányában egyenesen úgy fogalmaz, hogy ,a trópusok hatóköre még a müvészetnél is szélesebb: velejárója mindenféle alkotásnak". 58

Mindez egyszerre jelenti a szövegnek a nyelvi eszközökkel megvalósuló közvetítettségét, és egyúttal jellemzi a befogadás viszonylatában folyamatosan mozgásban lévő értelmezői tér átmeneti, rögzítetlen voltát. A metaforizáció ezt a szövegmozgást annyiban idézi, hogy általa nem pusztán ebben a folyamatban résztvevő trópusok és az

\footnotetext{
${ }^{55}$ Vö. Jacques DERRIDA: A fehér mitológia. (A metafora a filozófiai szövegben.) Ford.: Boros János Csordás Gábor - Orbán Jolán. In: THOMKA Beáta (szerk.): Az irodalom elméletei V. Jelekor, Pécs 1997. 5103.; illetve Paul Ricoeur: Metafora és filozófiai megnyilatkozás. Ford.: JENEY Éva. = UÖ.: Válogatott irodalomelméleti tanulmányok. (Szerk.: SzEGEDY-MASZÁK Mihály). Osiris, Bp., 1999. 214-218.

${ }^{56}$ DE MAN: Szemiológia és retorika. $=$ Uö.: i. m. 23. Azzal együtt, hogy „De Man azonosító gesztusa a metafora sokat emlegetett tipikus trükkjét alkalmazza: a metafora azonosít ugyan, csakhogy közben megtartja az azonosító és azonosított közötti különbséget. A jelentéstöbblet abból adódhat, hogy a két terminus azonosítása olyan szemantikai réseket nyit meg, ahol a különbségek áttünnek a hasonlóságokon." Vö. DARABOs Enikő: A trópusok hatalma. In: i. m. 46.

${ }^{57}$ Lásd pl. A gondolati tér és a metaforikusság összefüggéseiről a filmben: Jan SIMONs: Film, Language and Conceptual Structures. (Thinking Film in the Age of Cognitivism.) University of Amsterdam, Amsterdam, 1995.

${ }^{58}$ Jurij LotMAN: A retorika. Helikon, 1999/1-2. 93.
} 
ezeket alkotó kisebb szövegegységek (szavak, szókapcsolatok) egymáshoz való viszonya hangsúlyos, hanem a köztük lévő, de a szöveg egésze szempontjából is értékelhető relációké. Ezáltal pedig maguk a trópusok is közbenső és közvetített elemmé válnak, amelyek nem garantálják, legfeljebb felerősítik a szöveg ilyetén müködését. A viszonyítási, értelmezési pozíciók folyamatos áthelyeződésével az ún. szó szerinti jelentés mint alapkategória háttérbe (egy viszonyrendszerbe) kerül; vagyis nem kiinduló pont (amihez képest a metafora értelmezhető) hanem a szónak, kifejezésnek egy bizonyos (a tágabb szövegkörnyezettől sem független) szövegbeli megjelenése, akárcsak a metaforikus.

Bezeczky Gábor a metafora és narráció kérdéskörét tárgyaló könyvében - Ricoeur elmélete nyomán - a metafora trópusa és a metaforizáció mint az egész szövegre kiterjedő szemantikai müvelet közti viszonyt hangsúlyozza: ,a folytonosság helyi és globális metaforikusság” összekapcsolásával. Felfogásában a metafora alapját képező szemantikai kölcsönhatások nem csupán a lexikalitás szintjén érvényesülö jelenségnek tekinthetök. A „kontextuális kölcsönhatások összefüggésében” a metaforicitás dialogikus módon „két különböző kontextusnak, két különböző gondolatkörnek, a lehetséges állítások két különböző halmazának az összeütközéséből áll elő". ${ }^{59}$ A metafora így a dialógus-fogalom segítségével már Bahtyin elméletében is párhuzamba állítható a metaforikus jelölési eljárásokkal, melyek során: „a két nyelv között lezáratlan dialógus kezdődik, mely magában a képben zajlik; a kép az egyes világok, nyitott, eleven kölcsönhatások játékterévé válik." ${ }^{\circ 0}$ Ezekre a felismerésekre is alapozva Olasz Sándor megállapítja, hogy „a regény metamorfózisának egyik kulcsfontosságú jelensége a próza metaforizálódása”, amely véleménye szerint sem valamiféle regénytípus vagy stílusmegjelölő fordulat. A „metaforikusság - fogalmaz a szerző - nemcsak textuális (nyelvi-stilisztikai), hanem strukturális szinten is meghatározza az epika szerkezetét." ${ }^{\prime 61}$

Jurij Lotman (korábban említett tanulmányában) az egyes kulturális korszakok szóképekre orientálódó jellegéből kiindulva mutat rá a retorikai alakzatok kontextuális megközelítési módjára. „Ha általánosítjuk ezeknek a szövegalkotó struktúráknak a szemantikai elveit - mondja Lotman - akkor minden bizonnyal meghatározhatjuk a szókép tipológiai természetét is.” A trópusokat ő is a „szövegalkotó struktúrák” részeként, ezekhez való viszonyuk szempontjából tárgyalja. Bár a szövegek értelmezhetőségét alapvetően a

\footnotetext{
${ }^{59}$ BEZECZKY: i. m. 209., 206., 218.

${ }^{60}$ A metafora bahtyini megközelítését és a szerző eddig magyarra nem fordított, témát érintő szövegrészleteit lásd: S. HoRvÁth Géza: A szókép és a nyelv képe: a kétszólamú szó képi természete Mihail Bahtyin regényelméletében. Világosság, 2003/11-12. 103-111.

${ }^{61}$ OLASZ Sándor „Hagyománytörténés” és elbeszélö technikák az újabb magyar regényben. = Uö.: Regénymúlt, regényjelen. Széphalom Könyvmühely, Bp., 2006. 40.
} 
kulturális kontextusok oldaláról vizsgálja, azonban mindez írása alapján nem választható el a tropikus vonatkozásoktól. Saját megfogalmazásában: „a szövegnek különböző metakulturális struktúrákhoz való viszonya szemantikai játékot teremt, amely feltétele a szöveg retorikai szervezettségének", ${ }^{6}$

Ezzel összefüggésben hangsúlyosan megkülönbözteti a trópusok keletkezését, kialakulását, illetve a müködésmódjukat, amelyben a szó szerintihez viszonyított metaforikus jelentés sem tekinthető rögzítettnek, kiszámíthatónak. „A konkrét és az átvitt jelentés között egyik esetben sem áll fenn (sem a metafora, sem a metonímia tekintetében) kölcsönösen egyértelmü megfeleltetési viszony, hanem csak hozzávetőleges ekvivalencia. Azokban az esetekben, amikor az állandó használattól vagy egyéb más oknál fogva a konkrét és az átvitt jelentés (trópus) között kölcsönösen egyértelmü megfelelés jön létre $s$ nem szemantikai oszcilláció - olyan szóképpel lesz dolgunk, amelyik megkopott és csak keletkezését tekintve retorikai alakzat, de úgy müködik, mint nyelvi frazeologizmus.",63

A trópusoknak ez a szemantikai oszcillációja erősödik fel, vagy vezetődik el a szövegkörnyezet és a tágabb kulturális kontextus függvényében. Ezáltal pedig a metafora mint kitüntetett trópus eltünik, beolvad abba a rendszerbe, amelyben legfeljebb közvetítő funkcióval bír, és e köztes közbülső helyzetben a reláció egyik elemévé válik, amely nem önmagára, hanem az általa (is) előidézett szövegmüködésre irányítja a figyelmet. A nyelvi struktúra illetve a tropikus viszonyrendszer részeként bármely ezeket idéző, ezek mintájára szerveződőnek felismert szövegrész ,gyanússá” válhat az értelmezés szempontjából.

Ezt a müködésmódot hivatott jelölni az intermedialitás (intermedier) terminus, amely során a trópusok a szövegben - miként az intermedier átöröklés élettani jelenségekor az utódban a szülők sajátságai - keveredve jelentkeznek. A metaforizációnak, mint köztes folyamatnak, értelmezendő viszonyrendszernek az egyik jellemzője éppen ez az intermedier szerveződés, miáltal a metaforikus szerkezet és maga a metafora a nyelvbe, kontextusba ágyazódva értelmezhető, és nem ezek egyszerü, visszafejthető jelentéséhez viszonyítva. ${ }^{64}$

$\mathrm{Az}$ intermedialitás ekként értelmezett terminusa több ponton érintkezik az intertextualitás jelenségével. ${ }^{65}$ Azonban míg ez utóbbinál (a legszükebb értelemben véve)

\footnotetext{
${ }^{62}$ LOTMAN: i. m. 101.

${ }^{63}$ Ua. 92.

64 Nem véletlen, hogy Orosz Magdolna e témában alapvető fontosságú könyve egyaránt kitér az intertextualitás és metaforikusság szövegszervező vetületeire. Vö. OROSZ Magdolna: „Az elbeszélés fonala”. (Narráció, interrtextualitás, intermedialitás.) Gondolat, Bp., 2003.

${ }^{65}$ Lásd pl. PETHŐ Ágnes (szerk.): Képátvitelek. (Tanulmányok az intermedialitás tárgyköréből.) Scientia, Kolozsvár, 2002.
} 
„két vagy több szöveg együttes jelenlétéből fakadó kapcsolat” illetve „egy szövegnek a másik szövegben való tényleges jelenléte" 66 a hangsúlyos, addig az intermedialitás nem pusztán a konkrét szövegek közötti kapcsolatformára mutat rá, ${ }^{67}$ hanem az ezeken belül, köztes módon érvényesülő tropikus müködésre, amely persze nem függetleníthető az adott kontextustól, szövegmezőtől, sőt hatványozottabban jelentkezik ezek találkozásakor.

A fogalomtörténetet mellőzve az intertextualitás-meghatározások közül leginkább a kristevai kapcsolódik az intermedialitáséhoz, mely kiegészülve az ideologéma terminussal a szövegkapcsolatok jelelméleti vonatkozásaira is rámutat. Az intertextualitás, mint a szövegen belüli „textuális interakció” nem függetleníthető ennek kontextuális (kulturális, társadalmi) vonatkozásaitól, mely szintén (miként a szöveg részeként a trópusok is) egy meghatározott nyelvi struktúraként realizálódik. Az ideologéma lesz Kristevánál az „az általános funkció, amely az intertextualitás terében egy konkrét struktúrát (mondjuk a regényt) más struktúrákkal (mondjuk a tudomány diskurzusával) kapcsol össze. Egy szöveg ideologémája más textusokkal való kapcsolatán keresztül az „adott »szövegszervezet« (szemiotikus praxis) és a saját terébe asszimilált vagy külső (szemiotikus praxisok) szövegek terében hivatkozásul szolgáló megnyilvánulásokkal (szekvenciákkal) való egybevetése". ${ }^{68}$ Az így megképződő struktúrák, akár a metaforikus szerveződések, köztes, kapcsoló szerepü kategóriáknak tekinthetők, a szövegek közötti reláció kialakulásához azonban nem feltétlenül szükséges diskurzusváltás.

Ezen a nyomvonalon haladva javasolja Benyovszky Krisztián, hogy „,ne csak intratextuális, hanem szövegek közötti, intertextuális metaforikusságról is beszéljünk”. ${ }^{69}$ A metaforizáció ekként az intermediális viszonyrendszer, továbbá a különböző műalkotásformák közötti interpretatív átjárhatóság szempontjából egyaránt működtethető, akár a képzőmüvészetet, akár a filmművészetet vonódik be a szövegtérbe. ${ }^{70}$

\footnotetext{
${ }^{66}$ Gérard GENETTE: Transztextualitás. Helikon, 1996/1-2. 8.

${ }^{67}$ Vö. Szajbély Mihály: Intermediális randevúk a 19. században. Pannónia, Pécs, 2008.

68 Julia KRISTEVA: A szövegstrukturálás problémája. Helikon, 1996/1-2. 19-20.

${ }^{69}$ BENYOvszKY Krisztián: Az elbeszélt metafora. Világosság, 2006/8-9-10. 137-144. Vö. „Úgy vélem, hogy a metafora alkalmas az elbeszélő szövegekben megjelenő szituációk, epizódok, karakterek vagy sorsok közötti párhuzamok és analógiás alapú szerkezeti törvényszerüségek leírására is, mivel ezen jelenségek felismerésének, megértésének és értelmezésének hátterében ugyanazok a gondolkodási müveletek állnak, amelyek lehetővé teszik számunkra, hogy metaforákat alkossunk és sikeresen interpretáljunk." http://www.vilagossag.hu/pdf/20070507213815.pdf (2008. május 15.)

$70 \mathrm{Az}$ intermedialitás mint viszonylag új területe az irodalomtudománynak gyakran a különböző szövegformák, nyelvi létmódok közötti kapcsolatrendszerek feltérképezése közben kapcsolódik az intertextuális és metaforikusság jellemzőihez. KulcSÁR SzABÓ Ernő, SzIRÁK Péter (szerk.): Történelem, kultúra, medialitás. Balassi, Bp., 2003. SÁGHY Miklós: Filmszakadás a szövegtérben. (Mándy Iván Régi idők mozija címü kötetének néhány jellegzetességéről.) In: HózSA Éva, SAMU JÁNOS Vilmos (szerk.): Szakadás(köz)vetitések. (Irodalom és medialitás.) Forum - Újvidéki Egyetem, Magyar Tannyelvü Tanítóképző kar, Újvidék - Szabadka, 2008. 113-146.
} 
Gérard Genette felosztásában az architextus terminusa abból a szempontból látszik leginkább közelíteni a fentebb intermedialitásnak nevezett szövegszerveződési módhoz, hogy esetében is konkrét szövegbe beépülö, azzal kölcsönös, jelentéstermelő viszonyt kialakító struktúráról, általánosabb viszonyrendszerről beszélhetünk. „A poétika tárgya fogalmazza meg Genette - nem a maga különösségébe vett szöveg [...], hanem architextus az, vagy - ha jobban tetszik - a szöveg architextualitása [...], azaz az általános vagy transzcendes kategóriák - diskurzustípusok, közlésmódok, irodalmi müfajok stb. együttese, amelybe minden egyes szöveg beletartozik." A metaforizáció így intermediális jellegénél fogva szintén „transzcendens kategória”, „amely legfeljebb egy tisztán rendszerbéli hovatartozására utaló paratextuális jelzést ad", adott esetben egy szövegszinten megjelenő egyszerü trópus formájában. ${ }^{71}$

Egyik szövegnek, szövegegységnek a másikkal való átmeneti, az értelmezés során aktualizálódó kapcsolata sem függetleníthető tehát, az ezek hátterében meghúzódó architextusoktól, így például az ekként értett metaforikus szerkezetektől. Mindezekkel összefüggésben tropikus lehet tehát az alapvető trópusokra visszavezethető, azokat idéző szövegmüködés. Ilyenformán a trópusok viszonyként elgondolt müködésük következtében nem kell, hogy egyértelmüen a retorika vagy stilisztika körébe utalódjanak. A nyelvi struktúra vagy a tropikus viszonyrendszer részeként bármely ezeket idéző, ezek mintájára szerveződő feli szövegrész metaforikusnak tűnhet az értelmezés szempontjából.

Artur C. Danto a Metafora, kifejezés és stílus címü írásában leginkább a befogadó oldaláról vizsgálja a klasszikus trópusoknak az interpretációban betöltött szerepét. Ebből a „gyakorlati szempontból” ítéli meg a retorika funkcióját is, mellyel összefüggésben a művészet egyik célja „,nem annyira reprezentálni, hanem inkább oly módon reprezentálni a világot, hogy az egy adott attitűdöt és egy speciális látásmódot eredményezzen”. Danto ebben a müvészetfilozófiai írásában képzőművészeti alkotásokból kiindulva hívja fel a figyelmet arra a következményre, hogy „ha a müalkotások struktúrája ugyanolyan, vagy nagyon hasonló a metaforák struktúrájához, akkor a müalkotásoknak semmiféle parafrázisa vagy összefoglalása nem tud olyan hatást tenni a befogadóra, mint maga a müalkotás; és a mű belső metaforájának semmiféle kritikai taglalása nem tudja helyettesíteni a müvet". Mindez - a disszertáció témáját tekintve - nem a metaforaelméletekből ismert parafrázisteszt vagy a metafora ,különlegességének” a felismerése miatt érdekes, hanem a metaforikus szerkezet és a műalkotás struktúrájának viszonyára vonatkozó belátásai miatt. Nem szabad, hogy elkerülje a kritikusok figyelmét, - írja Danto, hogy - ,az a komplex

\footnotetext{
${ }^{71}$ Gérard GeneTte: i. m. 82., 85.
} 
struktúra, amit a mü befogadásának lehetősége foglal magába, valamint az, hogy a mü leírására használt nyelv és maga a mü tapasztalása [értelmezése, mondhatnánk szöveg esetén] bonyolult viszonyban állnak egymással." Danto írásának Szövegek címü alfejezetében immár az irodalmi müvek tekintetében fogalmazza meg ennek a viszonyrendszernek a lényegét, és egyben felhívja figyelmet a kulturális kontextus értelmezésben betöltött szerepére is. „A metafora tehát prezentálja tárgyát és ezen túlmenően azt a módot is, ahogyan prezentálja azt. [...] A metaforákban a »prezentálás formája« természetesen azokkal a jelentésekkel és asszociációkkal rendelkezik, amelyekkel a korszak kulturális kerete rendelkezik."72

Nem újkeletủ az a felismerés sem, hogy az ekként értett metaforizáció nem utalható egyértelműen a líra és a stilisztika körébe. A prózai szövegek szövegszerveződésének tropikus jellegével már több hazai teoretikus foglalkozott (Kulcsár Szabó Ernő, SzegedyMaszák Mihály, Bezeczky Gábor, Thomka Beáta és mások), ${ }^{73}$ ugyanakkor a szöveg tropikus viszonyait figyelembe vevő más szempontú (narratológiai) vizsgálatot is elősegítheti a retorikai jelenségek olyan elméleti keretben történő megközelítése, amely rálátást enged ezeknek a szövegformáknak a nagyobb (kontextuális, intertextuális) egységeire.

\section{A mese mint narratív forma: mese és metaforikusság}

A mese, mesemondás és -hallgatás közhelygyanús, de találó fordulattal élve: egyidős az emberiséggel. A téma tárgyalását talán mégsem érdemes Ádámmal és Évával kezdeni, habár, már csak a (természetes) nyelv jellemzői vagy az emlékezés narratív természete miatt is emberelőtti időkre vezethető vissza a kérdés. A nyelvnek mint a gondolkodás, a kommunikáció vagy az érzelemkifejezés eszközének, Platóntól Wittgensteinig, meghatározó a használati értéke, és ezzel összefüggésben társadalmi természete. ${ }^{74} \mathrm{~A}$ nyelvfilozófia egyik alaptétele szerint az emberré válás nyilvánvaló feltétele a természetes nyelv mint alapvető szemiotikai rendszer elsődlegessége. A nyelv akár tehát alapvetően a

\footnotetext{
${ }^{72}$ Artur C. DANTo: Metafora, kifejezés és stílus. Ford.: Sajó Sándor. In: BACsó Béla (szerk.:) Szöveg és interpretáció. Cserépfalvi, Szekszárd, é. n. [1991.] 129-166.

${ }^{73}$ Vö.: Kulcsár SzABÓ Ernö: Metaforikusság és elbeszélés. = Uö.: Müalkotás - szöveg - hatás. Magvető, Bp., 1987. 71-73.; BEZECZKY Gábor: Metafora és elbeszélés. Literatura, 1992/1. 3-25. SZIGETI LAJOS Sándor: Parabola és/vagy metafora? (Történelmi regény a kisebbségi magyar irodalmakban.) = Uö.: (De)formáció és (de)mitologizáció. (Parabolák és metaforák a modernitásban.) Messzelátó. Szeged 2000. 88-109.

${ }^{74}$ Vö. FARKAS Katalin - KelEMEN János: Nyelvfilozófia. Áron, Bp., 2002. 49-54., 58-59.
} 
gondolatok kifejezésére és a világ reprezentálására szolgáló kommunikációs eszköz, vagy akár mindenféle emberi tevékenységet és életformát meghatározó használati mód; valamiféleképpen minden emberi kultúrában megfigyelhető rendszer.

Anélkül, hogy a nyelv keletkezésének egyéb filozófiai, nyelvészeti kérdéseit érintené a dolgozat, érdemes megállapítani, hogy a mese jó néhány párhuzamot mutat a nyelvnek elsődleges szemiotikai rendszerként elgondolt jellemzőivel. Mind az emberi gondolkodás, mind pedig a kommunikáció kezdeteinek egyik alapvető megnyilvánulási formája a mítosz és a mese. Éppen ezért az utóbbi évtized kutatásaiban nagy hangsúlyt kapott a mese és a szakralitás kapcsolata, valamint ezzel összefüggésben a mese és kommunikáció vizsgálata.

A Mese és szakrális kommunikáció címü írásában - Kerényi Károly, Jelezar Meletinszkij, és Láng János mítosz és meseértelmezésére hivatkozva - Bódis Zoltán a szakralitásnak a mese kialakulásában betöltött szerepére hívja fel a figyelmet: „,a mese részben a szakrális tudatformák hanyatlásának eredménye, s ahol a szakrális tudatforma már nem képes egységes és állandó mitologikus-vallásos világkép megteremtésérefenntartására, ott megnő a képzelet szerepe, megindul a fikcionalizálódás, a mesévé válás folyamata". ${ }^{75}$ Ugyanakkor a szerző utal a mese és szakralitás megítélésének egy másik lehetséges módjára is, mely álláspont a (természetes) nyelv használati értékéhez, és társadalmi természetéhez hasonlóan a szakralitást, ezen keresztül pedig a mesét az emberi tudat egyik alapvető megnyilvánulási formájának tekinti. „,...a szakralitás az emberi tudat sajátossága, tehát a mesék e tudatformákhoz természetes módon kapcsolódnak. A mesék figyelmeztet Bódis Zoltán, így - „a mitologikus-vallási elemeket nem szervetlenül, [...] törmelékesen hordozzák, hanem épp a szakrális tudatformának egy általánosabb érvényü jelenségeiként érthetők meg." ${ }^{, 76}$

Mindez természetesen nem csupán a C. G. Jungnak mesékben és mítoszokban fellelhető ősképeket érintő vizsgálata vagy Mircea Eliade a mesék és beavatási rítusok kapcsolatát hangsúlyozó elmélete felöl érdekes. A mese mint emberi tudatforma a létmegértés egyik eszköze, olyan meghatározó kommunikációs forma, mely az emberi gondolkodás, nyelvhasználat alapvető jellemzőit mutatja.

Király Jenő a mesevilág ontológiájáról szólva Ernst Bloch gondolatait idézi, aki „az

\footnotetext{
75 BóDIs Zoltán: Mese és szakrális kommunikáció. In: BÁLINT Péter (szerk.): A meseszövés változatai. (Mesemondók, mesegyüjtők és meseírók.) Didakt, Debrecen, 2003. 139.

${ }^{76}$ Uo.
} 
ember rendeltetésének kutatásában látja a mítosz, mese és filozófia közös feladatát”.77 Érintsen a mese akár ontológiai akár metafizikai kérdéseket, megítélésében érdemes számolni mind az orális hagyományban gyökerezö, archaikus és szakrális létértelmező szerepével, mind pedig kommunikációs eljárásként különböző szövegformákkal érintkező nyelvi, narratív és poétikai aspektusaival. Nem véletlenül nyomatékosítja Honti János alapvető munkájában a mese müfaji kategóriákon túllépő jellegét: „,..a mese másvalamiből származik, és nem saját csírájából fakad. [...] ...a mesevilág létezik a mesén kívül is - alles ist ein Märchen -, a legősibb mítoszoktól a mai ember ábrándozásáig mindenütt ott van mese nélkül is a mese világa." ${ }^{, 78}$ Ekként érthető Balázs Bélánál a mese elragadtatott méltatása („,hajlandók vagyunk azt hinni néha, hogy a mese a koronája a müvészetnek”), ${ }^{79}$ vagy Max Lüthi és a fiatal Lukács György (,a mese - [...] - úgy viszonylik az összes többi műfajhoz, mint a nemeukledesi geometriák az eukledesihez”) és mások ezzel nagyon is összecsengő vélekedése. ${ }^{80}$

A „mítosztól a mesébe vezető úton” haladva Meletyinszkij szerint épp a deszakralizáció és demitologizáció folyamataként, a szakrális jelleg elvesztése során határolható el a mese a mítosztól. A folyamat során a mese „mindinkább elveszíti kommunikatív funkcióját” és az egyes archaikus motívumok végül a mesei koncepciónak alapjaként „az ősibb, ténylegesen mitológiai magot bővítik ki”. ${ }^{81}$

A mese és szakralitás kapcsolatának más megközelítése, a kommunikáció részeként, a kulturális antropológia kérdésirányai nyomán, ${ }^{82}$ a mese ontológiai státuszát figyelembe véve tárgyalja a kérdést. „Ha a mesét a kommunikáció egy sajátos formájaként fogjuk fel - fogalmaz Bódis Zoltán -, akkor a mese célja nem e jelentések generálása, hanem a kommunikációs folyamat megteremtése. Ugyanakkor [...] nem kell a kommunikáció szintjén a mesék végső ontológiai szintjeként kinyilatkoztatni, elképzelhető egy magasabb szint is, s így a mesék mint kommunikatív egységek megőrzik

\footnotetext{
${ }^{77}$ Vö. Ernst BLOCH: Tübinger Einleitung in die Philosophie. Bd. 1. Frankfurt am Main, 1963. Idézi: KIRÁLY Jenő: Frivol múzsa (A tömegfilm sajátos alkotásmódja és a tömegkultúra esztétikája.) 1-2. Nemzeti Tankönyvkiadó, Bp., 1993. 246.

${ }^{78}$ HonTI János: A mese világa. Magvető, Bp., 1962. 74, 76.

${ }^{79}$ BALÁzs Béla: Halálesztétika. = Uö.: Halálos fiatalság. (Drámák, tanulmányok.) Magyar Helikon, Bp., 1974. 317.

${ }^{80}$ Vö. A mese „a költészet egyik ösformája”. MAX Lüthi: Es war einmal. Vom Wesen des Volksmärchens. Vandenhoeck \& Ruprecht, Göttingen, 1998. 114. és LuKÁcs György: Hét mese. = Uö.: Balázs Béla és akinek nem kell. (Összegyüjtött tanulmányok.) Kner Izidor, Gyoma, 1918. 105.

${ }^{81}$ Vö. MeleTYINSZKIJ: Mítosz, mese, eposz. = Uö.: A mítosz poétikája. Ford.: Kovács Zoltán. Gondolat, Bp., 1985. 338-347.

${ }^{82}$ Ebben a megközelítésben „a szakrális jelenségek »gondolatok és cselekedetek rendszer«, az életvilágnak olyan jól szabályozott közös gyakorlata, amelyben »egy közösség saját magát, saját magának alakítja«, illetve magát fejezi ki saját maga számára" Vö. BóDIs Zoltán: i. m. 139., 141. A belső idézetek lásd: LovÁsz Irén: Szakrális kommunikáció. Európai Folklór Intézet, Bp., 2002. 15.
} 
többértelmüségüket". ${ }^{83}$

Voigt Vilmos a folklór poétikájának vizsgálata kapcsán talán ezért tartja elengedhetetlennek a kommunikációelmélet alkalmazását, nem függetlenül a kultúra megjelenési formáinak, stílusának kérdéseitől. ${ }^{84}$ A népi elbeszélés hagyományos szövegformáinak tárgyalását az emberi memória belső szerkezetével összefüggésben, a szájhagyományozódás által felvetett kognitív pszichológiai és tanuláselméleti szempontok mellett, a szövegnyelvészet eredményeinek felhasználásával, a narratív struktúrák vizsgálatával tartja kivitelezhetőnek Hoppál Mihály. Az emlékezés és elbeszélés kérdése alapvetően mégis kultúra- és kommunikációelméleti vonatkozásban értékelhető, ahogyan a szerző fogalmaz: „a kultúra igyekszik megőrizni a saját identitását fenntartó szövegeket, s erre többféle csatornán, többféle mechanizmust tart üzemben. A (népi) szóhagyomány különféle müfaji (mint pl. a mítosz, a mese, a hősének), a hiedelemrendszer hálószerủen szervezett struktúráival, valamint a beszélt nyelv mindennap használt és beidegzett szerkezeteivel együtt alkotják azt a mechanizmust, amely az adott kultúra hosszú távú emlékezetét karbantartó szövegeket létrehozza". 85

A mese mint szépirodalmi müfaj és a rövidpróza egymáshoz való viszonya kapcsán Thomka Beáta nagyon pontosan fogalmaz: „a kortárs rövidpróza köznapi történeteiben anekdotikus csattanók, más formaelemek, előképek, mesék, mítoszok nyomai is felsejlenek. Az irodalomban tehát rejtett emlékképek müködnek (G. Hartman), a kultúrának vannak emlékezetnyomai és létezik müfaji emlékezet. Ez a folyamatszerüség egyik aspektusa. Az átörökített prózaformák szövegközi és müfajközi energiaforrások lehetnek akkor is, ha ideiglenesen vagy tartósan nem állnak az elbeszélői érdeklődés előterében”. ${ }^{86}$

A dolgozat alapvető megközelítési szempontja a mese eredeti, orális hagyományhoz kötődő jellegének figyelembe vétele, amely nem függetleníthető néhány retorikai és kommunikációelméleti kérdéstől sem. A mesének mint kommunikációs stratégiának a szocializáció folyamatában betöltött szerepe hangsúlyozódik többek között David Riesman munkáiban. Az ő kommunikációelméleti modelljében a mese mint karakterformáló tényező jelenik meg, és a nyelv-hatalom összefüggésrendszerében válik fontossá. ${ }^{87}$ Azt, hogy ez a megközelítés korántsem idegen az irodalmi folyamattól, jól példázza Sophia Menache könyve, a The vox Dei, mely a Communication in the Middle

\footnotetext{
${ }^{83}$ BóDIs Zoltán: i. m. 142-143.

84 Vö. VoIGT Vilmos: A folklór stilisztikája és poétikája. In: HoppÁL Mihály (szerk.): Elbeszélés és emlékezet. Európai Folklór Intézet - Osiris, Bp., 2001. 71-76.

${ }^{85}$ Hoppál Mihály: Elbeszélés és emlékezet. In: Uö.: (szerk.): i.m. 128.

${ }^{86}$ THOMKA Beáta: Beszél egy hang. (Elbeszélők, poétikák.) Kijárat, Bp., 2001. 12-13.

${ }^{87}$ Vö. David Riesman: A magányos tömeg. Közgazdasági és Jogi Könyvkiadó, Bp., 1983. 148-176.
} 
Ages alcímet kapta, és a kommunikáció kérdéseit vizsgálja a középkori irodalomban, illetve kultúrában. ${ }^{88}$ Munkájának első fejezetében például a közvélemény alakításának, a politikai ideológia és a vallás viszonyának kérdéseit érinti, ebben a korai és civilizációs problémáktól látszólag távoli korszakban.

A mese nyelvi, szocializációs vonásai mellett eleven irodalmi hagyományként elsődlegesen mégis asszociatív, felidéző funkciója, valamint az értelmezést inspiráló vonása az, amelynek nyomán az általánosabb prózapoétikai, metaforaelméleti kérdésék is bevonhatók a vizsgálódások körébe. A mese mint narratív eljárás megítélésekor ennek műfaji jellemzői felvetik a metaforizáció tropológiai vonatkozásait, szemben például az alapvetően metonimikus szerveződésünek elgondolt, kauzális viszonyokra épülő prózamodellről alkotott elképzelésekkel. ${ }^{89}$

A mese így nem azonosítható a történettel, és nem utalható problémátlanul a „mesehangulat”, „mesei stilizáltság” típusú leegyszerüsítő kifejezésekkel a stilisztika vagy a gyermekirodalom körébe; hagyománytörténeti és beszédmódbeli sajátságai nagyban befolyásolhatják a vele kapcsolatba lépő (kis)próza-formák megítélését is. A vonatkozó szakirodalomnak pszichológiai szempontú, az egyes meseszövegek strukturális vagy motivikus elemzését elvégző része így ez esetben mellőzhető, s a mesetipológiától vagy a mümeséken belüli differenciálástól eltekintve jelen esetben a mese hagyománytörténeti, prózapoétikai vonatkozásai tekintendők elsődlegesnek. ${ }^{90}$

A mese és elbeszélés viszonyát érintő mostani kutatás Csáth Géza és Szini Gyula prózáját vizsgálva elsősorban a prózapoétika és a neoretorika határterületén tájékozódva arra a kérdésre irányul tehát, hogy a 20. században egyre meghatározóbbá váló metaforikus prózamodellt (Krúdy Gyula, Kosztolányi Dezső stb.) hogyan készítik elő, illetve előlegezik meg az egyes írások, összekapcsolódva a mese műfaji és szemléletmódbeli jellemzőivel, mintegy legitimálva az anekdotikus, és szecessziós-szimbolista hagyománytól is eltávolodó történetmondást.

${ }^{88}$ Vö. Sophia Menache: The vox Dei. Oxford University Press, New York, 1990.

$89 \mathrm{Ez}$ persze nem jelenti a klasszikus retorika tipológiáját követő metafora kontra metonímia vita felelevenítését, vagy semmilyen ezzel kapcsolatos sarkos állásfoglalást. Tény, hogy Jakobson szövege nyomán a hazai tudományos diszkurzusban is sokáig tartotta magát az a tény, hogy míg a líra és versszövegek metaforikus jellegűek, addig a próza, az elbeszélés elsősorban metonimikus szerveződésü. Ugyanakkor már a nyolcvanas években megindult ennek az álláspontnak az elvetése, és elsősorban Kulcsár Szabó Ernő, Thomka Beáta, Szegedy-Maszák Mihály majd Dobos István igyekezett rámutatni a prózaszövegek metaforikus jellemzőire. (Lásd: Thomka Beáta, Szegedy-Maszák Mihály, Kulcsár Szabó Ernő, már idézett tanulmányait, és DoBOs István: Alaktan és értelmezéstörténet címü könyvét.)

90 E vizsgálat szempontjából így mellőzhetők olyan, egyébként alapvető, a mese témáját pszichológiai aspektusból érintő munkák, mint Bruno BETTELHEIM: A mese büvölete és a bontakozó gyermeki lélek. Ford.: Kúnos László. Gondolt, Bp. 1988., vagy Marie-Louise VON FRANZ: Az árnyék és a gonosz a mesében. Ford.: Orosz Magdolna, Zalán Péter. Európa, Bp., 1998. 
A „mesék”, „mese-novellák” stiláris jellemzői sem elszigetelten, sokkal inkább a beszédmódot meghatározó, a nyelvi, retorikai megoldásokat kísérő jelenségként ítélhetők meg. A látszólag különböző stílusú és hangvételü novellák közös jellemzője a disszonancia és határhelyzet nyelvi, poétikai formáinak megtalálása, melyek párhuzamba állíthatók a pszichoanalitikus gyakorlatnak és a mesélésnek, mesemondásnak a szoros kapcsolatával. Közös bennük a mesének az Ezeregyéjszaka meséit és az ekként jelölt archaikus, orális műfaji hagyományt idéző jellege, melyben a történetmondás, a folyamatos beszéd a (szövegben)létezés ontológiai és textuális alapfeltételévé válik.

Csáth Géza és Szini Gyula prózáját olvasva a mese eredeti, orális hagyományához kötődő sajátságainak figyelembe vételével válik értelmezhetővé novellisztikájuknak ,a mesélés körülményeit, társadalmi szabályait”, valamint ezeknek szövegszerü, az irodalmi prózaformákban felbukkanó jegyeit érintő része. ${ }^{91}$

\footnotetext{
${ }^{91}$ KIBÉDI VARGA Áron: Népmese és irodalomelmélet. = UÖ.: Szavak, világok. Jelenkor, Pécs, 1988. 101.
} 


\section{A varázsló kertjéből a sétapálca-erdőbe -}

mese és metaforikusság Csáth Géza és Szini Gyula szövegtereiben

„Félúton a novella brutális sötétje és a rege kristályos áttetszősége között helyezkedik el a mese. [...] áttetszö közeg, de nem átlátszó; tengerszín mélység, alakok rajzolódnak ki benne az olvasó szemének, de egészen megfoghatóvá nem válnak. [...]

A mese novella, melyben kísért valami. És pedig olyan kísérteties jelentés..."

Michel Tournier ${ }^{92}$

A 19. és 20. század fordulója mint időszak és kulturális tér egyaránt kitüntetett jelentőségü, egyfajta fordulópont a kultúra és irodalom vonatkozásában. Elsősorban az Osztrák-Magyar Monarchia területén és az 1890-től a 1910-es, 20-as évekig terjedő írásművészetet (irodalmi, esztétikai, filozófiai) szokás a századforduló irodalmaként aposztrofálni. Az ekként jelölt időszak alkotásai elsősorban az itt artikulálódó problémák és kulturális jelenségek kapcsán rokoníthatók egymással. Legyen az irodalmi szubjektum-objektum viszony átalakulása, ${ }^{93}$ az identitás elbizonytalanodása (többek között Nietzsche, Freud munkái nyomán), vagy a valóság részekre hullása, a fantasztikum szerepének felértékelődése (E.T.A. Hoffman, Hofmannsthal); mindez nagyban befolyásolja az irodalmi szövegek tematikus és diszkurzív jellemzőit is. Több hazai kutató, többek között Alexa Károly, Bori Imre, Bodnár György, Dér Zoltán, Dobos István, Eisemann György, Orosz Magdolna, Szajbély Mihály vagy Thomka Beáta és mások a századforduló irodalma kapcsán rámutattak e korszak müfaji összetettségére, a stílusirányzatok gazdagságára és jó néhány poétikai jellegzetességre. E disszertációnak természetesen nem feladata mindezek átfogó tárgyalása, ezért elsősorban a fejezetcímben jelölt problémakörre koncentrálva a mese és a metaforikusság jellemzőit érinti a századforduló elbeszélésirodalmában.

Ma már irodalomtörténeti közhelynek számít a korszakban általános mesekultusz és a metaforikus szövegszerveződés hangsúlyossá válása. Az értelmezők mindkét kérdéskört gyakran egyidejüleg és azonos korpuszt érintve tárgyalják, a két jelenség kapcsolódási pontjaira viszont alig tértek ki. Ugyanakkor gyakran éppen az alternatív tudatállapot, a valóságsíkok többszöröződése nyomán kialakuló szövegvilágok, vagy egyszerűen a fantasztikum jelenléte és az irreális elemek történetalakító szerepe folytán összekapcsolható a metaforikus próza és az egyszerü formák kérdésköre, a mese, a mítosz,

\footnotetext{
${ }^{92}$ Michel TOURNIER: Kékszakáll, avagy a mese titka. = Uö.: A vámpír röpte. (Mủelemzés és műkritika, a Trisztántól Grassig.) Ford.: N. Kiss Zsuzsanna. Napvilág, Bp., 2001. 35.

93 Vö. Wolfgang RIEDEL: „Homo natura”. Literarische Anthropologie um 1900. de Gruyter, Berlin-New York, 1996. Idézi: Orosz Magdolna: „Az elbeszélés fonala”. (Narráció, intertextualitás, intermedialitás.) Gondolat, Bp., 2003. 207.
} 
a legenda vagy netán a babona szövegszervező potenciálja. ${ }^{94}$ A hagyományos elbeszélői minták és müfaji modellek átértékelése az intertextuális újraértelmezés mellett, vagy éppen ennek nyomán, az elbeszélés hitelességének relativizálódását, a narrátori pozíció elbizonytalanodását, a korszak irodalmának reflexív, nyelvkritikai attitüdjét erősíti. Legyen az akár a hofmannsthali nyelviségre visszavezethető „minden részekre esett szét” felismerés, amikor „[...] már semmit sem sikerült egyetlen fogalommal” megragadni, ${ }^{95}$ vagy akár Nietzsche vélekedése a világ jelenségeiről alkotható igaz kijelentések lehetetlenségről a nyelvi közvetítettség, a jelszerüség és referencialitás folytán. ${ }^{96}$ Orosz Magdolna a narráció, intertextualitás és az intermedialitás témakörét tárgyaló könyvében ezt a tendenciát az egyén ön- és világtapasztalatának változásával összefüggésben tárgyalja, széles kulturális és nyelvfilozófiai szempontrendszer bevonásával.

Csáth Géza tanulmányait, esszéit vagy akár naplóját vizsgálva kitünik a novellisztikájában gyakran felbukkanó mesélés, mese fogalmak fontossága, sőt teoretikus megalapozottsága. Mindezekkel összhangban a mese mint egyszerü forma, irodalmi hagyomány és kommunikációs stratégia az elbeszélés-szerkezetbe épülve müfaj- és hagyománytörténeti jellemzői felől válik meghatározóvá.

Szini Gyula novellisztikájának kevésbé kanonikus részében (a Mese „alkonya” címü esszéjében tematizált) a mesehagyományt érintő alapvető kérdések szintén helyet kapnak. Többek között A smaragd, a Rózsaszínü hó, A sétapálca-erdö azok az olyan kevésbé tárgyalt szövegek, amelyek alapján kitünik: a Szini-korpusz és az életmü megítélése nem szükíthető a nosztalgikus hangvételü, lírai hajlamú szecessziós elbeszélésekre. Jellemző ebből a szempontból, hogy novellái közül ugyanaz a néhány darab jelent meg a későbbi válogatott kiadásokban, és fel sem merült az összegyüjtött novellái kiadásának szükségessége. ${ }^{97}$ Ugyanakkor a korpuszból egy-két elbeszélést

${ }^{94}$ Vö. Tarjányi Eszter pontos megfogalmazásával: „’a mese’ azért lesz poétikai kulcsfogalom a századelőn, mert általa válik érzékelhetővé a metonimikustól a metaforikusság felé, a konkréttól a jelképesség felé, mimetikustól a diegetikusság felé, a cselekményességtől a hangulatiság irányába, a lélek-, jellem- és társadalomábrázolás helyett az atmoszférateremtés felé tapogatózó poétika tájékozódási pontjai." Vö. TARJÁNYI Eszter: A mesenovella poétikai szerepe a századforduló irodalmában. (Ambrus Zoltán három mesenovellája.) Literatura, 2008/4. 470.

95 Vö. Hugo von Hofmannsthal: Lord Chandos levele címü esszéje. Idézi: Orosz Magdolna: „Az elbeszélés fonala", i. m. 208.

${ }^{96}$ Vö. Friedrich NIETZSCHE: A nem-morális felfogott igazságról és hazugságról. Athenaeum, 1992/3. (Ford.: Tatár Sándor) 3-15.

${ }^{97}$ Ez persze magyarázható azzal a „túltermelési” deficittel, ami - éppen általa $A$ mese „alkonya” című esszéjében megfogalmazva - a korabeli olvasói igényeket kielégíteni igyekvő elbeszélés-irodalmat jellemezte, és Szini prózáját is elérte, továbbá azzal, ahogy - Hites Sándor találó megfogalmazásával Szini mintegy „kiírta magát a kánonból”. Vö. HiTES Sándor: Szini Gyula-visszaírás. In: EISEMANN György (szerk.): A kánon peremén. (Az irodalmi modernség alakváltozatai a XIX-XX. század fordulójának magyar prózájában.) ELTE XVIII-XIX. Századi Magyar Irodalomtörténeti Tanszék, Bp., 1998. 86. 
(elsősorban A sárga batár, és a Tücsökdal címüeket) mozgató mai értelmezések is egyértelművé tették, hogy az újabb elméleti megközelítések felöl is újraolvashatónak bizonyul Szini Gyula novellisztikája. ${ }^{98}$

A tematikus jellemzőkön túl egyaránt lényeges ezekben a novellákban az irodalmi hagyományt értelmező jelleg, valamint a mítoszhoz és a meséhez való interpretatív, dialogikus viszonyulás. A mese a reális-irreális oppozíciójára, a fantasztikum felé hajló történetre vagy az álomlogikára épülő jellemzőivel a metaforikus, asszociatív, disszonáns szövegeljárások meghatározó közegét jelenti Csáthnál és Szininél egyaránt.

A Szini-szövegek irodalomtörténeti jelentőségének, a korabeli elbeszélőprózában elfoglalt helyének, szerepének megítélésében fontos lehet az ezidáig nem érintett írások hasonló poétikai, retorikai elméleti bázisra támaszkodó értelmezése. Szini Gyula novellisztikájának, valamint ennek a korabeli, és a későbbi prózairodalomhoz való viszonyának megértéséhez engedhetetlen az életmünek a teljes novellisztika fényében, sőt az újabb elméleti kutatásokkal összefüggésben végzett vizsgálata. Az említett okokból és forrásokból kiindulva tehát az itt megkezdett munka mellett szükségesnek látszik a korabeli hetilapokban, időszaki kiadványokban megjelent Szini-szövegek felkutatása, feldolgozása, melyet szerencsés esetben egy szövegkiadás követhetne.

Csáth Géza „népszerüségének” korlátozott jellege olyan kanonizáción nyugszik, mely viszonylag kevés jelentőséget tulajdonít a szerző elmeorvosi-pszichoanalitikus, valamint zene- és irodalomkritikusi, teoretikus munkásságának. A 20. század eleső felének irodalmát, irodalmi gondolkodását érintő legújabb kutatásokban azonban már nem véletlenül szerepel a Csáth-életmü mindeddig kevésbé kutatott része. A Ráció-Tudomány sorozat egyik, a 20. századi magyar irodalomtudományt a műfajiság, kulturális emlékezet és medialitás szempontjából vizsgáló kötetében így kaphatott helyet a csáthi alkotótevékenység. Sebestyén Attila a pszichofiziológiai müvészet- és kultúraelmélet keretei között tárgyalja a „Csáth-jelenséget”, mely szerinte egy médiaantropológiai megközelítésben felfogható ,,a különböző művészetek-médiumok átlelkesítő/megelevenítő hatásának folyamatos újrafelfedezéseként; míg a több képességü alkat tevékenységében

\footnotetext{
${ }^{98}$ Több, a Szini-novellisztikát tárgyaló írás készült a legutóbbi időszakban, részben HiTES Sándor: Szini Gyula-visszaírása nyomán és helyenként azt követve. A témát érintő munkák azonban alig jutnak túl a korabeli Szini-recepció áttekintésén, és/vagy a mesenovellának a századforduló irodalmában elfoglalt szerepének, helyének tárgyalásán. Tényleges szövegértelmezésre, Szini Gyula elbeszéléseinek nyelvi, retorikai feltérképezésére alig vállalkozott valaki. Kivételként lásd pl. Tarjányi Eszternek fentebb idézett, a századfordulós mesenovella poétikai szerepét hangsúlyozó, és $A$ mese „alkonyá"-t érintő írását, valamint Schultz Adrienn szövegét, Paradigmaváltó lehetöségek Szini Gyula novellisztikájában. In: MASZÁROviCS Ágnes, MÉszÁros Márton (szerk.): Jelenlét '07. (Tanulmányok.) Károli Gáspár Református Egyetem Bölcsészettudományi Kar, Irodalomtudományi Doktori Iskola kiadványi 3., Bp., 2009. 45-62.
} 
kirajzolódó határzónák az említett megkapó hatást (...) biztosító intermediális konfigurációkkal rokoníthatók*”. Jó látja a szerző, hogy „a Csáth-életmű azt is példázza továbbá, miként teremtődnek mégis ötvöződések, kapcsolódások a (pszichofizikai többletekből kinövő) különböző formák és médiumok heterogenitásában, diszkontinuitásában*". ${ }^{99}$ Ezek a formák és médiumok mint nyelvi formációk, mintázatok és müfaji lenyomatok egyúttal poétikai szempontokat is implikálnak.

A korpusz nyelvi-retorikai alapú, a fenti szempontokat bevonó megközelítése ugyanakkor más megvilágításba helyezi a Csáth-novellisztika eddig olvasott részét is. A magyar prózairodalomban a romantikus, anekdotikus, majd a 20. századi metaforikus elbeszélés közötti poétikai ív megrajzolása szempontjából is adhat néhány támpontot az említett szerzők írásainak vizsgálata.

\footnotetext{
99 SEBESTYÉn Attila: Agyvelö-akrobatika. Egy pszichofiziológiai müvészet- és kultúraelmélet keretei Csáth Gézánál. In: BóNus Tibor, KulCSÁR-SzABÓ Zoltán, SiMON Attila (szerk.): Az olvasás rejtekútjai. Müfajiság, kulturális emlékezet és medialitás a 20. századi magyar irodalomtudományban. Ráció, Bp., 2007. 156. A kiemelések a szerzőtől, az idézetek belső hivatkozásai K. Ludvig PFEIFFER: A mediális és az imaginárius. Egy kulturantropológiai médiaelmélet dimenziói. Ford.: Kerekes Amália. Ráció, Bp., 2005. $21-22$. szöveghelyére vonatkoznak.
} 
„Azt mondta, bagoly vagy, úú, úúú, én vagyok a kezdet, úú. Ide tartozol hozzánk baglyokhoz a fügefán, és nem ahhoz a valakihez, aki fóz az Istenverte Apádra, úú, ...”

Adrienne Kennedy ${ }^{100}$

A fejezetcímben jelölt - elöször a Budapesti Naplóban, 1906. június 7-én publikált Csáthírás, később pedig a Magvető Kiadó gondozásában megjelent összegyüjtött novellák kötet $^{101}$ címében szereplő - rosszul kifejezés különösen sokatmondó. Az e fordulattal összefoglalt történetek mindegyike (miként a kötetben szereplő Csáth-novellák nagy része is) „rosszul végződik”. Az alatta olvasható írások rendre ontológiai megsemmisüléssel, és/vagy a párválasztás meghiúsulásával érnek véget, rácáfolva egyúttal a népmesék „boldogvégződés”-követelményére. ${ }^{102}$ A tematikus jellemzőkön túl, ezek a novellák formai és müfaji szempontból is árulkodóan hasonlóak. Egyaránt meghatározó az irodalmi hagyományt értelmező jellegük, valamint a mítosszal és mesével mint egyszerü formával illetve a tradicionális elbeszélői mintákkal való szoros kapcsolatuk. ${ }^{103}$

A Második mese a bibliai József és testvérei-történetre reflektálva egy korabeli József és Putifárné szerepeltetésével ironizál a matrimoniális szokásokon, felvetve egyúttal élet, élés versus irodalom, írás alapdilemmáját. József itt Königsbergben él, mely szemben Budapesttel - hangsúlyozza a narrátor - nem tudta megmenteni a nőgyülölettől. Az Immanuel Kant nevével és életrajzával szorosan összekapcsolódó emblematikus helyszín tovább erősíti az említett szembeállítást. Ugyanakkor ezzel párhuzamosan a narrátori

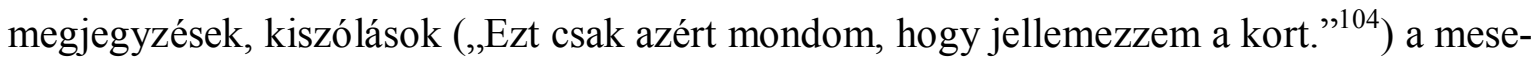
mondás és/vagy novella-írás elbeszélői állásfoglalását is problematizálják. Különösen figyelemreméltók ezekben az írásokban azok az irónia és profanizálás stilisztikai jellemzőit kísérő poétikai, retorikai megoldások, melyek az életmű kontextusába szervesen illeszkedő alapkérdésként tüntetik fel az említett irodalmi hagyományhoz, műfaji mintákhoz való

\footnotetext{
${ }^{100}$ Adrienne KenNedy: A bagoly válaszol. Ford.: Kiss Attila. (Herbert BlaU: A test, amely meghaladja önmagát címü szövegével osztott oldalon.) Gondolat-jel, 1994/1-2. 21.

${ }^{101}$ CsÁth Géza: Mesék, amelyek rosszul végzödnek. (Összegyüjtött novellák.) Szerk.: SzAJBÉLY Mihály. Magvető, Bp., 1994. (A továbbiakban: CsÁTH: i. m.)

${ }^{102}$ Vö. NAGY Olga: Táltos és pegazus. Holnap, Bp., 1993. 99.

${ }^{103}$ Csáth ezen írásai leginkább a nyitott formájú rövidtörténettel mutatnak rokonságot, mely „dialógust kezdeményez a jelképekkel, a mítosszal". Vö. TномкA Beáta: A pillanat formái. (A rövidtörténet szerkezete és müfaja.) Forum, Újvidék, 1986. 59.

${ }^{104}$ CSÁth Géza: Második mese. $=$ Uö.: i. m. 51.
} 
dialogikus, interpretatív viszonyulást. A Harmadik mesében például a párválasztáskor kiszemelt lányt jellemezve a narrátor külön kitér arra, hogy ,,szabályos és kerek volt a válla, izmos a háta (csak kevés, de anatómiailag igen jól elrendezett hájjal)” majd, miközben az orvos-kérő laboratóriumi vizsgálatnak veti alá választottja vérét, az elbeszélő - mintegy ironikusan saját korábbi leírására és annak stílusára reflektálva - megjegyzi: „Majd titokzatos kis üvegekből öntözgetett hozzá, amelyeken ilyen furcsa - szeretném mondani, hátborzongató - fölírások voltak láthatók: $\mathrm{CHO}-\mathrm{NaOH}-\mathrm{CHNS}$ ". ${ }^{05}$

A „szeretném mondani” elbeszélői óhajban az említett narratológiai dilemma (mese-mondás és/vagy novella-írás) részeként a mondható kontra írható poétikai különbözősége is kifejeződik. A szavak hangzásának fontosságára, a paranomázikus ${ }^{106}$ többértelmüségben rejlő lehetőségekre Csáth az 1914-16-os naplójának több bejegyzésében kitér. Egy álmát elemezve, (melyben leírja, hogy a feleségét Olgát várja, hogy mihamarabb közösülhessenek) az „ezután átmegyek a bazin felé” részhez analízisében az angol 'bazen' (basin) 'mosdó, mosdótál, lavór, medence' szóhoz a következő megjegyzést füzi: „bazin = basz-szín”. ${ }^{107}$ A paranomázikus szófelbontás és az álomleírásban olvasható „bazin” kontaminált alak az álom egészével összefüggésben így retorikailag 'a vágyott aktus tervezett színhelye' jelentést kapja. Másutt hasonló módon a mikráscsík-rovar csípésétől való félelem magyarázatakor álomanalízisében a „mikro és csík (csíp) összetétele" etimologikus szófelbontásból indul ki. ${ }^{108}$

A (ki)mondhatóság vágya, a történetmondás szituációja a mese müfajának orális jellemzőivel és ennek hagyománytörténeti tapasztalataival kiegészülve teszi összetetté a Mesék, amelyek rosszul végzödnek tematikusan egyszerü, hangvételében könnyed írásait, indokolva a Varázsló kertje kötetben elfoglalt helyüket, felhívva egyúttal a figyelmet az életmủ más szövegeinek ilyetén összefüggéseire.

Ugyan ,a századforduló új magyar irodalma mindent mesének tartott, ami nem volt tradicionális, nem volt anekdotikus" mégis úgy tűnik, ${ }^{109}$ hogy a Csáth-novellisztikában több szinten jelentkező mese korántsem tekinthető kordivatnak, és nem egyszerüsíthető a

\footnotetext{
${ }^{105}$ CsÁth Géza: Harmadik mese. i. m. 51-52. [A kiemelés tőlem. B. S.]

${ }^{106}$ Vö. „A hangzásbeli összecsengés megfeleléseinek enyhébb formája az annominatio (R: egyszármazatú nevezés) vagy paranomasia (adfictio, R: szójáték), mely (pseudo)etimologikus szójáték az azonos szótövekkel (figura etymologica), illetve az azonos hangzású, de különböző jelentésű szavakkal. Hatásuk egyfelől a hangzásbeli változás csekélységében, másfelől az érdekes jelentésváltozásban rejlik.” SzABÓ G. Zoltán - SzÖRÉNYI László: Kis magyar retorika. Helikon, Bp., 1997. 117.

${ }^{107}$ CSÁth Géza: Fej a pohárban. (Naplók és levelek 1914-16). Szerk.: SzAJBÉLY Mihály. Magvető, Bp., 1997. 157-158.

${ }^{108}$ Ua.170-171.

109 ALEXA Károly: Világkép és novellaforma a XIX-XX. század fordulóján. (A mese felkutatása, kifosztása és megsemmisítése.) = Uö.: Eleitől fogva (Tanulmányok, esszék). Kortárs, Bp., 1996.
} 
történet egy mü cselekményének szinonimájává. A mese, mesemondás, mesélés esszéiben, kritikáiban is olyan gyakran előforduló kifejezés, melynek használata teoretikus megalapozottságról, határozott müfajelméleti- és történeti elképzelésről tanúskodik. ${ }^{110}$

Mindezeket figyelembe véve elöljáróban megállapítható, hogy Csáth elbeszéléseiben, így a Varázsló kertjének novelláiban sem azonosítható a mese a történettel, és nem utalható problémátlanul a mesehangulat, mesei stilizáltság típusú leegyszerüsítő kifejezésekkel a stilisztika vagy a gyermekirodalom körébe. ${ }^{111}$ Narratológiailag a történet-elbeszélés fogalompárral ${ }^{112}$ összefüggésben a mese inkább olyan terminusnak tünik, melyben az elbeszélésre mint narratív szerkezetre jellemző módon „az alapforma deformációjával a diszharmónia válik a mủvészi hatás központi elemévé". ${ }^{113}$ Mindemellett a mese a reális-irreális oppozíciójára, a fantasztikum felé hajló történetre vagy az álomlogikát követő müködésmódra épülő jellemzőivel ezeknek a „torzszülött”, disszonáns szövegeljárásoknak egyik legitimáló közegét jelenti Csáthnál. Elsődlegesen eleven irodalmi hagyományként mégis asszociatív, felidéző funkciója és az értelmezést inspiráló vonása tünik különösen meghatározónak.

Csáth naplójegyzeteiből ismeretes kifinomult vonzódása egyes tárgyakhoz, ezt egy helyütt így magyarázza: „Tegnap egy tüneményes borosty[án]szipkát vásároltam [...] Szebb az ónixnál, és különösen a legújabb példánynak a mészbeszürődés révén prezentálódó rajza elragadó szép. Finom és érdekes vonalak, tömörülések a különös aranyszínű átlátszó alapanyagban az allúviumról mondanak mesét, és adnak hírt. Micsoda titáni föld alatti erők hozták létre ezeket a hullámos vonalakat..."114

A tárgy látványa mintegy a mese felidéző szerepét helyettesítve hozza létre a rögtönzött történetet, nyelvileg ugyanakkor a leírásban a mese szó kerül a tárgy helyére kölcsönösen magyarázva egymást, mely asszociációs müködésnek az egyik bizonyítéka maga az így létrejött narratíva, a napló-szöveg.

\footnotetext{
110 Vö. CSÁTH Géza: Friss könyvek. = Uö.: Rejtelmek labirintusában. (Összegyüjtött esszék, cikkek tanulmányok, újságcikkek.) Szerk.: SzAJBÉLY Mihály. Magvető, Bp., 1995. 98-101.; Cirkuszmulatság. = Uö.: Ua. 13-14.; Jegyzetek Mikszáthról és új regényéröl. = Uö.: Ua. 123-134. Egy Jókai-regény analizise. = Uö.: Ua. 137-142.

111 Elsősorban a mesék müfaji és beszédmódbeli sajátságai befolyásolják a velük kapcsolatba kerülő (kis)próza-formák megítélését. A vonatkozó szakirodalomnak pszichológiai szempontú, az egyes meseszövegek strukturális vagy motivikus elemzését elvégző része így ez esetben mellőzhető, és a mesetipológiától vagy a mümeséken belüli differenciálástól eltekintve a mese hagyománytörténeti, prózapoétikai és befogadáselméleti vonatkozásai tekintendők elsődlegesnek. [Az így értett mese terminust a továbbiakban dőlt szedéssel jelölöm. B. S.]

${ }^{112} \mathrm{Vö.} \mathrm{a} \mathrm{fabula/szüzsé,} \mathrm{historie/discours,} \mathrm{plot/story} \mathrm{terminusokkal.}$

${ }^{113}$ THOMKA Beáta: i. m. 76.

114 Csáth Géza: Fej a pohárban. (Naplók és levelek 1914-16). Szerk.: SzAJBÉLy Mihály. Magvető, Bp., 1997. 117. [A kiemelés tölem. B. S.]
} 
Kosztolányihoz írott egyik levelében Csáth egy közösen készítendő operaszövegkönyv ötlete kapcsán fejti ki ezzel kapcsolatos nézeteit: „Zenésítésre pedig azért alkalmas, mert általánosan ismert történet, be van idegezve reá a közönség és az új relációk, a mese teljessége is alkalmas reá, hogy a közönségben már meglévő emlékeket hatalmas erővel ébressze fel". ${ }^{115}$

Dobos István - igaz, ugyan a lírai hangoltság részeként elgondolt mesei stilizálással összefüggésben - figyelmeztet arra, hogy ,a mese nemcsak fabula-alkotó elem. Másodlagos, metaforikus jelentést sürít magába, s ennek révén a motivációs rendszerben is szerepet kap. Az író úgy építi be az elbeszélés-szerkezetbe, hogy hihetővé teszi, s egyben értelmezi is a történetet. Voltaképpen az elbeszélői reflexiók és utalások szerepét veszi át oly módon, hogy egy általánosabb jelentésdimenzió, összegzőjelkép felől is rálátást enged a novella teremtett világára."

Így az említett csáthi „mesék”, „mese-novellák” stiláris jellemzői sem elszigetelten, sokkal inkább a beszédmódot meghatározó, a nyelvi, retorikai megoldásokat kísérő jelenségként ítélhetők meg. A mesék alaki, formai mintáit követő írásokban az ezekre reflektáló, illetve ezeket továbbíró gesztus és a hozzá kapcsolódó poétikai és narratológiai megoldások a meghatározóak. ${ }^{117}$

Mesealakulatok: mese-formulák és az elbeszélői keret

(A köszivü takaritónö, Mese az emberek rosszságáról, A mester meséi)

Meletyinszkij a mítosz és mese kapcsolatát vizsgálva utal arra a már említett deritualizálódási és deszakralizálódási folyamatra, melynek következtében „a mitikus hösök helyébe köznapi emberek lépnek, a mitikus kor helyébe meghatározhatatlan mesebeli idő, [...] a közösség sorsáról a figyelem átterelődik az egyén sorsára, a világmindenségről a szükebb társadaloméra, ebből fakad számos új szüzsé megjelenése”. ${ }^{118}$ A ,misztikus” mesék (Csáthnál is szerepel ez a cím!) ${ }^{119}$ fokozatosan közelítettek a fiktív szépirodalmi alkotásokhoz, és az egymással történő kontextuális kölcsönhatásba lépésüket is ez tette lehetővé. A müfaj eredeti, ősi jellemzőiből mégis

\footnotetext{
115 Ua. 276.

116 DoBOs István: Racionalitás és misztikum. (A novellaíró Csáth). In: DÉR Zoltán (szerk.): Emlékkönyv. (Csáth Géza születésnapjának századik évfordulójára.) Életjel, Szabadka, 1987. 120-121. [A kiemelés tölem. B. S.]

117 Vö. CsÁth Géza: A kőszívü takaritónő. = Uö.: i. m. 352-357., A mester meséi. = Uő.: i. m. 281-282.,

Pesti mese. = Uö.: i. m. 330-331., Történet a három leányokról. = Uö.: i. m.12-15.

118 Jeleazar MeletYinszKis: Mítosz, mese, eposz. = UÖ.: i. m. 340.

${ }^{119}$ Vö. CsÁTH Géza: Misztikus mesék. =UÖ.: i. m. 316.
} 
megőrződött annyi, hogy ezen „összefonódásban” az előbbiek épp e folyamat eredményeként megfejtendö, kevésbé érthető jelleget kölcsönöztek például a velük érintkező századfordulós „,mesenovelláknak”, amelyek így leginkább a mese specifikumai felől értelmezhetők.

Mindezek következményeként nemegyszer látszólag puszta kliséként ezekben a későbbi (a mesék helyét átvevő) írásokban is fellelhetők az elmondottak mesejellegére utaló ún. stilisztikai formulák. Ám Meletyinszkij is hangsúlyozza: „a fejlett klasszikus meseformában a hagyományos mesei fordulatok kifejezetten utalnak a mese és a mítosz között meglévő elvi különbségekre: idöben és térben meghatározatlannak mondják, szavahihetőségét kétségbe vonják stb.". ${ }^{120}$ Vagyis a mesei formuláknak lehet bizonyos műfaji differenciáló szerepük is. Csáth a meseelemek különböző szintű alkalmazásával így például jelezhette az általuk felidézett mitikus, orális epikus hagyománynak a fontosságát, például a korabeli anekdotikus írásokkal szemben.

Ilyen fordulat, formula az „egyszer volt, hol nem volt...” vagy „hol volt, hol nem volt..." ${ }^{121}$, ez utóbbit idézi a kötetből kimaradt írások között olvasható $A$ köszívü takarítónő is. „Hol volt, hol nem volt, volt a világon, Budapesten, kilencedik kerület, Ferenc körút negyvenhat földszint nyolc alatt egy hónapos szoba." ${ }^{, 122} \mathrm{~A}$ novella valóban egy egyszerű „modern pesti mese”. Az egészséges (utalások alapján valószínűleg) falusi környezetből a nagyvárosba „fölkerült”, kezdetben szorgalmas elsőéves orvostanhallgató (Vörös) életvitele, gondolkodása lassanként megváltozik, „önmagára talál”: ,a bölcsészeti fakultás filozófiai előadásaira kezdett járni, és szaktudományait elhanyagolta". Sőt „komolyan foglalkozott egy »rendszer« felállításával”, ami persze, mint később kiderül, már egy humán alapokon nyugvó, müvészi világlátásra épül, hiszen „a müvészet, a dolgok felületes látása sokkal mélyebb és igazabb betekintést enged az életbe". E felfogás jegyében alakítja a főhős a maga életét is, festőnek vagy írónak készül, mely területen „az érzelmeké, a müvészeté minden feladat”, melyek közül a legelső a világgal való „emberi viszonyt tisztázni". 123

Vörös célkitűzését illetően az emberek megfigyelésével - a narrátor indoklása

\footnotetext{
${ }^{120}$ Jeleazar MELETYINSZKIJ: i. m. 342.

${ }^{121}$ E formulák osztályozásával kapcsolatban (mesekezdő f., mesei átvezető f., mesezáró f., mesei sztereotípia stb.), bőséges példaanyaggal lásd: Magyar Néprajzi Lexikon, 574., 579.

$122 \mathrm{Az}$ alábbi idézetek mindegyike: CSÁTH: A köszivứ takarítónö. = UÖ.: i. m. 352-357.

${ }^{123}$ Mesevilág ontológiájában, az emberi-világ viszony tisztázásában éppen ezek az alapvető kérdések: „Milyen lenne a világ, ha mi teremtenénk? Milyenek lennénk, ha újjáteremtenénk magunkat? Milyen világ az emberhez illő? Ebben a megközelítésben a mítosz, a mese és a filozófia közös feladata az ember rendeltetésének kutatása, az „emberi viszonyt tisztázni”. Vö. KIRÁLY Jenő: Frivol múzsa. (A tömegfilm sajátos alkotásmódja és a tömegkultúra esztétikája.) 1. Nemzeti Tankönyvkiadó, Bp., 1993. 246.
} 
alapján - azért nem jutott semmire sem, mivel nem rendelkezett elég kitartással és elszántsággal. Ugyanakkor a szereplő belső monológjában ennek egy másik okát is megfogalmazza, miszerint „tulajdonképpen nincsen bonyolultság és nincs komplikáltság az emberi lélekben, mert minden csak látszólagos - érteni kell a kulcs megkereséséhez, ez az egész!”. Az emberi pszichének erre az erősen leegyszerüsített felfogására cáfol rá a főhős által ilyen „egyszerűnek” hitt takarítónő, aki ugyanakkor filozofikus rálátással ítéli meg a helyzetet. („Sajnálatos dolog, ha ilyen jó emberanyag, mint Vörös, meddő életre adja magát, ami tulajdonképpen bölcsesség, de általában butaságnak és érthetetlenségnek mondható.”) A narrátor, aki kezdetben nem véleményezte főhőse szavait, a novella vége felé „kiesve szerepéből” saját vélekedésének is hangot ad. („Így morfondírozott a szamár Vörös.”)

A történetben a fordulatot végül az eredményezi, hogy a takarítónő a maga egészséges, életelvü felfogását Vörösre, a gyenge akaratú emberre kényszeríti, és visszatéríti életét a „normális mederbe”. Erre az ötletre épül a novella, melynek befejezésében a tanulság összefoglalásával (,mindent csak akarni kell”) és a mesezáró formula alkalmazásával („még most is él, ha meg nem halt”) Csáth a mesét elsősorban narratív sémaként idézi fel.

Emellett azonban van a novellának egy másik lehetséges „üzenete” is, miszerint az emberi lélek és pszichikum jóval összetettebb, mint azt a föhős képzeli, és ahhoz, hogy valaki íróként vagy festőként valódi művésszé váljon, nem elég „megtanulni, hogy mindenkivel a maga nyelvén beszéljünk", illetve hogy ehhez a pszichikum (és a nyelv) korántsem ilyen felületes ismerete szükséges. Ezzel összefüggésben Csáth ebben az írásában is az adott müvészi célkitűzés rendszerré szervezésének fontosságát hangsúlyozza, mely a művészi világkép elengedhetetlen feltétele, és így ennek hiánya „eszmei síkon” is alátámasztja a főhős kudarcát.

Formailag hasonló írás a Mese az emberek rosszságáról címü is, ${ }^{124}$ mely szintén e legismertebb formulát építi be, és e formai keretben Csáth az egyszerü tanulság levonásáig jut. E tekintetben ezek a „mesék jól végződnek”, mégis tekinthetők antimeséknek, mivel kontrasztot képeznek a mese egyszerü, mechanikus formai követelményként történő felhasználása és az epikus hagyomány részeként felfogott alkalmazása között.

A mester meséiben Csáth elbeszélői keretbe helyezi a „meséket”, az ezáltal megduplázott elbeszélő-mesélők (Csáth narrátora és a történet szereplője mint elbeszélő) szólamai így éles kontrasztba kerülnek egymással, melyekben az eltávolításon túl erős

${ }^{124}$ CsÁTH: Mese az emberek rosszságáról. = Uô.: i. m. 344-346. 
irónia is érezhető. Mivel „,a keretet az elbeszélőnek a történettel szembeni álláspontja, jelöltté tett viszonyulása teremti meg,", ${ }^{25}$ itt maga az elbeszélő nevezi meg a hallgatóság által piedesztálra emelt mester történeteit, melyeket „klasszikus meséknek” tart, egyúttal pedig véleményezi is az ilyen típusú történetmondást. „A mester a kávéházban ül (hol is ülhetne máshol egy mester?) és társaságának - [...] - mesél, ami nem áll egyébből, minthogy egy elegáns és csodálatos mozdulattal kiveszi szájából a cigarettát, egy kanál feketét hörpent, azután beszélni kezd - jellemzi Csáth a mestert és egyúttal az általa képviselt mesét. „- Tagadhatatlan, hogy pózol az öreg, de nagyon bámulják. A mondanivalója és a módja napról-napra, akarom mondani meséről-mesére változik. - Hol cinikus, hol szentimentális, néha klasszikus, mint a »tanítványok« mondják, [...]. Sokszor bíztatják, hogy állítsa föl már a rendszerét, s akkor hadd essék hasra a világ, de mindeddig nem írt semmit a kitűnő mester."126

Csáth azzal, hogy éles ellentétbe állította a tanítványok nézőpontját az elbeszélői keret narrátori tudásával, nem csupán ironizálja azt, hanem a leírt, de a novellában meg nem valósult elvárásokban egyben a meséhez kapcsolódó nézeteit is megfogalmazza. A mester itt olvasható meséiről a tanítványok véleménye is egyöntetű („,ma klasszikus volt”) és nyoma sincs bennük az említett változatosságnak, egyedi és sokszínű stílusnak. Szajbély Mihály véleménye szerint e meséken ,ott van az olvasóit direkt módon tanítani és szórakoztatni akaró újságíró keze nyoma. Történetei így [...] nem lélekállapotokat keltenek, hanem tanulságokat sugallnak, tanmesékké válnak". ${ }^{127}$

Mint látható, Csáth Gézát foglalkoztatták ezeknek a „mesealkotó elemekre” épülő történeteknek a hiányosságai. A két „mese” közötti zárójeles részben, az ismétlődő cselekvés (cigarettázás) hangsúlyozásával éppen erre a mechanikus mesealkotó technikára játszik rá, melyet már a novella elején a mesével, pontosabban a „,mesével” azonosított ${ }^{128}$ („mesél, ami nem áll egyébből...”). ${ }^{129}$ Egyúttal pedig kijelölte azt az irányt (érdekes, változatos témák, sajátos, egyedített stílus, egységes elméleti „,rendszer”), amely a mese átértelmezésével párhuzamosan már egy „új műfaj”, a novella felé vezet.

\footnotetext{
125 THOMKA Beáta: A pillanat formái, i. m. 65.

${ }^{126}$ CSÁTH: A mester meséi. = Uö.: i. m. 281-282. [A kiemelés tőlem. B. S.]

127 SzAJBÉLY Mihály: Csáth Géza. Gondolat, Bp., 1989. 49-50.

128 Szini Gyula $A$ mese ,, alkonya” címú írásában mindkét (az idézőjeles és az idézőjelek nélküli) alak szerepel, és az eltérö írásképnek nála pontosan körvonalazható jelentésbeli megkülönböztető szerepe van. A „mese”, vagyis az ,amit elbeszélünk” Szini szerint az elbeszélés tartalmi része, maga a történet, a mondanivaló (fabula), amely azonban elválaszthatatlan az elbeszélés másik elemétől, a „stílustól”, az elbeszélés „hogyan”-jától (szüzsé), egyik a másikat feltételezi; egységként funkcionálnak. (Vö. Nyugat, 1908/1. 24-28.) Részletesen lásd: „,Keleti drágakövek” vs. „türelemjáték kövei”: egy „elméletpótló esszé” mesefogalma címü alfejezetben.

${ }^{129}$ Hasonló keretes megoldással és párhuzammal él Csáth a Mese a kávéházból című írásában (Vö. Uö.: i. m. 277-280.)
} 
Csáth írásait olvasva így jelentősebbnek tủnik a nyitott formájú rövidtörténetekkel való hasonlóságuk, amely „dialógust kezdeményez a jelképekkel, a mítosszal”. ${ }^{130}$ A Csáthnovellákhoz kapcsolódó, a mese egyes elemei által behozott müfajspecifikumok több szinten, mintegy rétegzetten jelentkeznek az írásokban. Az említett formai, más esetben pedig stilizáló funkciójú, egyszerű hangulati elemként elkönyvelt meseallúziókkal párhuzamosan megfigyelhető a mese összegző jelképként való felhasználása, melyben a mese müfaji, elbeszélőformai jellemzői is hangsúlyozódnak.

Természetesen az alábbi jelentéselemek (a mese szó különbözö jelentései) csak az áttekinthetőség érdekében választódtak szét, de egymást kiegészítve, feltételezve funkcionálnak, és hagyománytörténetileg is egységesen kötődnek a meséhez. Az idézett jellemzők tipizáló kiemelése is - a kizárólagosság legkisebb szándéka nélkül - az alapján történik, hogy az adott novellában szövegszinten éppen melyik jelentés a hangsúlyosabb. Megjegyezendő, hogy az egyidejüleg több jelentésben használt mese egyes szintjeinek tárgyalásakor a dolgozat szóhasználatában megjelenő felszíni, vagy szövegszintű (tematikus, hangulati), továbbá a mélyebb, szövegszervező (mesejelkép) rétegekre való felosztása, és ennek a szemléletnek a beépítése az interpretációba nem idegen a csáthi koncepciótól, sőt sokban hasonlít ahhoz. ${ }^{131}$

Körül-írás: a mese müfaji és tematikus elemei; a mesei jelképek (Pesti mese, A varázsló kertje, Történet a három leányokról)

A tematizált meseelemeket felvonultató írásokhoz leginkább az olyan „mesenovellák” sorolhatók, mint a Szombat este, A Vörös Eszti, A varázsló kertje, melyekben leginkább valóban stilizáló eszközként jelentkeznek a mesék. A recepció is (szinte kizárólag) az ezek alapján kirajzolódó mesefelfogást érintette. ${ }^{132}$ Nem kizárható azonban a jelkép értékű használattal összefüggésben bizonyos szavaknak az interpretációban betöltött szerepe sem, melyek a meséhez kapcsolt összegző jelképként az egymással kontextuális viszonyba lépő szövegek átfedési pontjai lehetnek. ${ }^{133}$

A varázsló kertje kötettel azonos évre (1908) datált Pesti mese formájában is jelentősen eltér a korábbi rövid, bevett fordulatokra építő „,mesék”-től, benne a mese nem

\footnotetext{
${ }^{130}$ THOMKA Beáta: A pillanat formái, i. m. 59.

${ }^{131}$ Vö. CsÁTH: Friss könyvek. = Uö.: Rejtelmek labirintusában, i. m. 99-100.

${ }^{132}$ Vö. pl. PomogÁts Béla: Búcsú az ifjúságtól (A Vörös Eszti című elbeszélés szerkezeti elemei). In: DÉR Zoltán (szerk.): i. m. 105-111.

${ }^{133}$ A kontextus szó alapjelentése kiterjesztve több szövegre, kiegészítve a genette-i intertextualitás („két vagy több szöveg együttes jelenlétéből fakadó kapcsolat” ill. „egy szövegnek a másik szövegben való tényleges jelenléte”) fogalommal. (Vö. Gérard GENETTE: Transztextualitás. Helikon, 1996/1-2. 82-90.)
} 
is valamiféle formai követelményként, hanem leginkább a mesehagyományt felidéző vonatkozásban szerepel. Itt a mese inkább tematizálva, mint alkalmazva, a valóságtól való elszakadás eszközeként, az irreális, vágyott világot legitimáló hivatkozási alapként jelenik meg. „A mese ugyanis - állapítja meg Szajbély Mihály - helyszínét, idejét és hősformálását tekintve egyaránt kötetlen, s már e müfaji sajátosságánál fogva is igazolhatja a valóság határain túlcsapongó írói fantáziát”. ${ }^{134}$

A novellában szereplő Mariskát, aki „úgy járt mint egy királykisasszony” e szavakkal jellemzi az elbeszélő: „... a nagyvárosban is falusi leányka maradt. Meséket olvasott, tündérekkel, aludttejjel, és a nagymamájával álmodott”. ${ }^{135}$ Továbbá „sajátságos” módon kerülte a flörtöket, nem kötött ismeretséget „különböző fiatalemberekkel”, „mely ismeretségek - mint mondják - a női fantáziát elragadják a mesék valóság nélkül való világából”. Mariska tehát saját mesevilágában, a mesék világában élt; így érthető, hogy „egy lovagot várt, egy királyfit vagy herceget. Egy hatalmas termetü, de kissé lányos arcú szőke férfiút, aki egyszer eljön majd lóháton, vagy még inkább egy óriási griffmadár hátán és elrabolja őt. [...] És Mariska várt, várt, várt...”.

„Egészen hibás volna a mese - reflektál az elbeszélő magára a müfajra - és kár lett volna bele is kezdeni - ha a lovag egy napon meg nem érkezett volna.” Meg is érkezett Höncs Pál mérnök személyében, aki „dúsgazdag ember, házai vannak, sok szeretőt tart, sokat utazik, sokat költ” és bár „Mariska álmaiban a lovag arca feltűnően hasonlított a mérnök úr arcára"; ezek a tulajdonságai mégsem fértek bele a lány mesevilágába. Öntudatosan el is határozta: ,- A szeretője sohase leszek, ha elvesz - elvesz, ha nem - hát nem”. Mivel pedig: „A mérnök tapasztalt fiú volt. Belátta, [...] hogy a leányka sohase lesz a szeretője" - ez utóbbi történt. A novella zárlatában Csáth nélkülözve a tanulságra kifutatott csattanót, A varázsló kertje darabjait idéző frappáns tömörséggel foglalja össze a továbbiakat: „Többet nem beszéltek egymással. [...] Mariska két év múlva egy bankhivatalnokhoz ment férjhez, egy alacsony, kövérkés férfiúhoz, és a mérnök arcképét a régi kis vászonzacskóban a szalvéták és abroszok csomója alá helyezte el. És azután csak nagy ritkán szedte elő”. Már ebben a novellában is megfigyelhető a mesének, illetve egyes kontextuális elemeinek jelképesen hozzá kapcsolódó, felidéző szerepủ müködése. Mariska, a saját mesevilágának részét képező, emlékeihez kötődő tárgy előszedésével idézi fel ennek formavilágát. ${ }^{136}$

\footnotetext{
${ }^{134}$ SzAJBÉLY Mihály: i. m. 49.

135 A novellából vett idézetek mindegyike: CsÁTH: Pesti mese. =Uö.: i. m. 330-333.

${ }^{136}$ Ilyen felidéző funkciót kaphat akár egy tárgy is. Lásd a már idézett, egy „borosty[án]szipka” vásárlásához kapcsolódó bejegyzést. Vö. CSÁTH: Fej a pohárban. i. m. 117., illetve a dolgozat 114. lábjegyzetét.
} 
A Pesti mesében tehát éppen a „,valóság” és a mesék képviselte irreális, vágyakban élő világ kerül összeütközésbe, és a történet szintjén ez utóbbi bizonyul erősebbnek. Az elbeszélésben azonban a szöveg narrátora annak a mesehagyománynak az ismerőjeként szólal meg, amelynek a főszereplő belső világában csak rendszertelen elemei jelenhettek meg - a „mesé”-ket jellemző sematikussággal, - ő maga viszont nem válhatott királykisasszonnyá. Jellemző ebböl a szempontból, hogy Mariska nem ír, még csak naplót sem, nincs stílusa (csak vágyai és titkai vannak), közvetlenül idézett szavai pedig folyton mások véleményét visszhangozzák. A benne élö mesevilág nyelvileg nem az övé, hanem az elbeszélőé (szemben a Misztikus mesék mesélőjével), mindez pedig inkább magyarázza a végkifejletet, mint a két szereplő képviselte erkölcsi világrend különbözősége. Csáth e novellájában szemben a tanmesék „mese”-fogalmával a hagyományos meseelemek (a királykisasszony és királyfi egymásra találása stb.) sajátos felhasználásával, a mesék müfaji, nyelvi és stílusbeli sajátságaira történő önreflexív rájátszással egy, a kibontakozó korszerü elbeszélőműfaj részeként értelmezi a mesehagyományt. ${ }^{137}$

A Pesti mesében is megfigyelhető, hogy: „a keretet alkotó nyitó vagy záró elbeszélői közlésekkel hasonló szerepet töltenek be a közbevetések, elbeszélői kiszólások is. A bevezető megjegyzések, az elbeszélői megszakítások úgy kívánják az olvasóhoz közelíteni a történetet, hogy az elbeszélőéhez hasonlatosnak mutatják annak helyzetét. Egyikük sem ismer minden részletet, tehát mintha együtt hódítanák meg a maguk számára a történet egészét." ${ }^{138}$ Mindez pedig a mesehagyománynak egy másik alapvető vonására is felhívja a figyelmet, a mesélő és hallgatója „intim” viszonyára és a mesemondói szerepnek a mese eredeti létezésmódjához, a szóbeliséghez kötődő sajátságaira. ${ }^{139}$ Hiszen a szóbeliség folyamatában a mítoszok és mesék ,mindig attól függően módosultak, hogy a mesélő szerint mi érdekelte leginkább a hallgatóit, és hogy mik voltak abban a korban a legfontosabb személyes és társadalmi problémák". ${ }^{140}$ A későbbi írásaiban a mese jelentésének csáth-i rétegei közül éppen ez, a mesemondás illúzióját felkeltő szóhasználat a leghangsúlyosabb. ${ }^{141}$ Azonban nem az író-mesemondó vágyai fogalmazódnak meg ezekben a novellákban, hanem az általa meglátott általános emberi vágyak, melynek az egyik természetes közege éppen a mese.

Másrészről a mese, mint archaikus elbeszélési forma egy későbbi kor irodalmi el-

\footnotetext{
${ }^{137}$ Vö. SzINI: A mese ,alkonya”, i. m. 27-28.

138 THOMKA: A pillanat formái, i. m. 61.

${ }^{139}$ Vö. „Hja! - valamikor kitárt kebellel szavalt a piacon Homer a sokaságnak...” (CsÁTH: Friss könyvek. = Uö.: Rejtelmek labirintusában, i. m. 99.)

${ }^{140}$ BetTELHEIM: i. m. 37.

${ }^{141}$ Vö. CsÁTH: Hajnali elbeszélés, A tüz papnője, Kisfiúk, Nervus rerum, A balerina apja című novellákkal.
} 
beszéléseivel kapcsolódik össze, ezért a minél tökéletesebb kódoláshoz elengedhetetlen fontosságú bizonyos ismeret mindkettőről, ami ez esetben a mese oldaláról jelent kihívást. Vagyis Csáth novelláinak elbeszélésként történő minél sokrétűbb értelmezése nagyban függ a befogadónak a meséről - azaz egy jól körvonalazható jellemzőkkel bíró epikus hagyományról - kialakított ismereteitől. A másik oldalról pedig ott vannak az elbeszélő számára korszinten adott lehetőségek „melyek közül a történeti fejlődés mindig másokat tesz hozzáférhetővé" ${ }^{142}$ E kölcsönös viszony ilyenképpen való felfogása fogódzót nyújt a csáth-i recepció meseértelmezése és a szövegekböl körvonalazható mesefelfogás különbségének megértéséhez.

Az előző alfejezetben tárgyalt, elsősorban alaktani kérdéseket felvető Csáth-írások mellett a korai novellák másik - már a korabeli recepció alapvetései között is szereplő és mindmáig általánosnak vélt - jellemzője a kizárólag hangulati hatásként elkönyvelt mesei stilizáció. Hogy csak egyetlen ilyen példát említsek, Pomogáts Béla A Vörös Eszti kapcsán írt tanulmányában így fogalmaz: „A gyermekkor tündéri világának írói újrateremtése nemegyszer a mese eszközeivel történt, a századelő későromantikus vagy szecessziós irodalma szerette a mesék csodálatos és varázslatos történetei révén kifejezni azt a nosztalgikus érzést, amelynek tárgya a gyermekkor vagy éppen az álmok, a képzelet birodalma volt.” Ugyanitt Bodnár György szavait idézve megállapítja: „A mese nála [Csáth Gézánál] is olyan stilizációs eljárásként kapott szerepet, mely a történet »értelmét« segített kibontani. [...] A mese ily módon a nosztalgikus érzés epikai köntöse lett, s a mesemotívum az elvágyódás fájdalmas közérzetét [!] fejezte ki”. ${ }^{143}$ E mesei stilizáló eszköznek a mese müfajspecifikumaival összefüggésben történő alaposabb vizsgálatával azonban ez az erősen leegyszerüsítő elképzelés módosíthatónak tünik. Dobos István - már idézett felismerésében - figyelmeztet arra, hogy „a mese metaforikus jelentést sürít magába, s ennek révén a motivációs rendszerben is szerepet kap. [...] Voltaképpen az elbeszélői reflexiók és utalások szerepét veszi át oly módon, hogy egy általánosabb jelentésdimenzió, összegző jelkép felől is rálátást enged a novella teremtett világára."144

Csáth Géza sokat idézett „mesenovelláival” kapcsolatban (Szombat este, Vörös Eszti, A varázsló kertje) - amelyek egy-egy mesealakot illetve szereplőt (varázsló, törpék, Homokember, boszorkány) vagy mesecímeket ( $A$ vasfejü, $A$ hét holló), esetleg azok szerzőit (Andersen) állítanak a történet központjába - is felvetődik egy más típusú, nem

\footnotetext{
${ }^{142}$ SzEGEDY-MASZÁK Mihály: Az irodalmi elbeszélés elméleti kérdései. In: KANYÓ Zoltán (szerk.): Narratológiai tanulmányok. Studia Poetica 1. Szeged, 1980. 340.

${ }^{143}$ Pomogáts Béla: Búcsú az ifjúságtól. (A Vörös Eszti című elbeszélés szerkezeti elemei.) In: DÉR Zoltán (szerk.): i. m. 105-111.

144 Dobos István: Alaktan és értelmezéstörténet, i. m. 120-121. [A kiemelés tőlem. B. S.]
} 
elsősorban a gyermekvilág hatásos múltidéző eszközeként feltüntetett mese-elgondolás, azonban még mindig a beemelt meseirodalmi hivatkozásokkal és a mesehangulat elemeivel összefüggésben.

Hangsúlyozandó tehát, hogy a Szombat estében felidézett gyermekkori miliő és a történet szintjén ahhoz kapcsolt különböző jellegü meseelemek nem feltétlenül és kizárólagosan a kettő egymást magyarázó, igazoló összekapcsolhatóságára utalnak. Az itt tematizált probléma, a mese szerepe a gyermeki gondolkodásban nem elemzési alap, hanem a mese hagyomány- és müfajtörténetével szoros rokonságot mutató fejlemény, következmény, de legalábbis szociológiai, befogadáselméleti kérdés. Arról nem is beszélve, hogy a mese mai társadalomban betöltött szocializáló funkciójának megváltozott megítélése nagyban módosít a Csáth számára még alapvető tapasztalatként meglévő mesegyermek viszonyon. ${ }^{145}$ E belátások pedig nemhogy nem zárhatók ki az értelmezésből, hanem egyenesen megkövetelik a korabeli értelmezési horizont kitágítását, elfogadva: „hogy a befogadás viszonylatában lehetőségként létező műalkotások a lezáratlan hatástörténeti folyamat alakulásában, múlt és jelen szüntelen párbeszédében teremtődnek újjá”. ${ }^{146}$ A mese fent említett jelképértékü használata Csáth novelláiban leginkább egy azok mögött meghúzódó látens hivatkozási alapként képzelhető el, müködési elvük megérthető a mese műfajában hagyománytörténetileg alapvető fontosságú mesei jelkép felől.

A mese kizárólagos összegző jelképként történő felhasználásának belátását és az interpretációkba történő beépítését nehezíti, hogy Csáth novelláinak egy részében e jelképhasználat olyannyira jelzésértéküvé vált, hogy gyakran elsikkad a novella más hangsúlyosabb jellemzői között. Nagy Olga idézett könyvében utal erre a folyamatra: „Ahogyan a burkok sokasodnak, szerepük mind nagyobb lesz, szférájuk mind kiterjedtebb, úgy zsugorodik össze mindinkább az ősi mag, szerepe mind kisebbé válik, jelzései pedig mind áttételesebbé.” Ezzel együtt azt is hangsúlyozza, hogy „a legősibb mag is, bármilyen sokszoros áttételben, de valamiképpen benne érződik a legkülsőbb burokban is."147

A „kizárólagos” jelképi használat azonban inkább hangsúlyeltolódást jelent, nem elszigetelt, önállósuló alkalmazást. Csáth novelláiban is többnyire más szavakkal összefüggésben, a kontextualitás részeként jelentkezik. A jelképes értékü, mesehagyományra utaló, de még tematikusan is értelmezhető meseelemek rétegzettsége, egyidejü használata leginkább a Történet a három leányokról című novellában figyelhető meg.

\footnotetext{
${ }^{145}$ A témában lásd pl. David RIESMAN alapvető munkáját $A$ mese és a technika; a karakterformáló tényezök alakulása címen. $=$ Uö.: i. m. 148-176.

146 DoBos: Alaktan és értelmezéstörténet, i. m. 45

${ }^{147}$ NAGY: i. m. 53. Csáth naplójegyzeteiből ismeretes, hogy ilyen felidéző szerepet betölthet akár egy tárgy is. Vö. 136. lábjegyzet, illetve CSÁTH: Fej a pohárban, i. m. 117.
} 
A történet szintjén, hangulati közegként beemelt meseelemek kezdetben egy külön mesevilágban zajló „békességes élet” keretéül szolgálnak. A három lány közül a „legkisebb aranyszőke hajú” és persze - Csáthnál rendszeresen a mesei stilizáláshoz kapcsolt helyen - kertben élnek az „őzikékkel meg az öreg, százéves baglyokkal, akiket nagyon szerettek mind a hárman”. ${ }^{148}$ E tematikus elemekkel keveredve a mese, egy orális hagyomány részeként felidézett cselekvés, a munkafolyamatot kísérő mesemondás szintjén is megjelenik. Jellemző módon a térbeli környezettel érzékeltetett időtlen, hermetikusan zárt világ az övék, miként a mesék kialakulásáé is. Érthető tehát, hogy nem hallott vagy olvasott mesékkel múlatják az időt (ami természetesen csak az évszakváltozásokkal mérhető a novellában), hanem maguk „teremtik” ezeket. „És mondtak gyönyörü hosszú meséket, amelyeket ki-ki maga gondolt ki."

A történetét tekintve ez az írás valóban inkább mese, mint novella. Az ,így múltak az esztendők...” meseformulával kezdődő rész egy-egy lány egy-egy éven át tartó szerelmének történetét ismerteti, melynek során nemcsak az egymással való korábbi, de a mesékhez füződő viszonyuk is megváltozik.

A szöveg érdekességét inkább az adja, hogy az egész történet metaszinten a mesei fantasztikum realizálódását, a deszakralizációt, az ősi egység megbomlását érzékelteti, valamint ennek következményeit a szereplők életében. A néhai egységes világlátás a három lány egységében jelenik meg. („Egy test, egy lélek volt ez a három leány, mert testvérek voltak, s nem volt titkuk egymás előtt, de még csak olyan gondolata se egyiknek is, amelyet a másik kettő ne tudott volna.” Vagy máshol, zárójeles megjegyzésként: „(Még lélegzetet is együtt vettek)". Azonban nem csak ez kapcsolja egymáshoz öket, hanem az egységes mitikus világlátáshoz kötődő, abból táplálkozó szóbeli cselekvés: „,..s mesélték egymásnak a csodálatosan szép meséket”. Illetve e kettő (a mesék közvetítette primitív világkép és az ebből merítő orális kultúra) kölcsönösen feltételezi egymást, ezért a történet szintjén a „nagy egységet”, összetartozást a külső realitás hatására az egy-ség váltja fel, a lovag - aki, ,(nem is volt még lovag talán, csak apród)” - csak egyenként, egyesével, mint egyszerü lányokkal tud érintkezni velük. .

Mivel ily módon az ősi egység felbomlik, az ebből táplálkozó, ehhez kötődő cselekvés, a mesélés is elhalt, illetve mint epikus műfaj realizálódik. A mitikus világlátás helyét a realitás veszi át, a mesékét pedig a deritualizálódott „egyszerü elbeszélés”. „Éjjel

\footnotetext{
${ }_{148}^{148}$ Az alábbi idézetek mindegyike: CsÁTH: Történet a három leányokról. = Uö.: i. m. 12-15.

${ }^{149}$ A természet ciklikusságának az elbeszélőszerkezetben betöltött szerepéröl lásd: Jurij LotMAN: A szüzsé eredete tipológiai aspektusból. $=$ Uö.: Kultúra, szöveg, narráció. (Orosz elméletírók tanulmányai.) Szerk.: Kovács Ârpád, V. Gilbert Edit: JPE, Pécs, 1994. 83-85.
} 
pedig, amikor a csendes szobájukban alszanak a százéves baglyok,... s a lányok beléunnak a fonásba meg a mesélésbe, némán néznek a gyertyalángba, s azután róla beszélnek, csak a lovagról...”. Különösen érdekes a novellának az a megoldása, amelyben az említett két szint, a történeté és a „mögötte” meghúzódó mesehagyomány metaszintjéé, a mindvégig ez utóbbit képviselő, baglyok szerepeltetésével összekapcsolódik. A „bölcs baglyok” által jelképezett ősi, de néma tudás, ennek folyamatos jelenléte a lányok (korábbi) életében, valamint a baglyok velük való szoros (,testi”) kapcsolata (velük esznek, alszanak) azt erősíti, hogy a szakrális, alapvetően a szóbeliségben meglévő mese, mesélés elképzelhetetlen valamiféle „ősi tudás” nélkül, elválaszthatatlan attól. ${ }^{150}$

Ezért, amikor a lányok élete és a vele járó irrealitás és misztikum a „valós élettel” való találkozáskor (lovag) reálissá vált, a baglyok csak „rosszkedvüen rázták a fejüket”, illetve „mogorvák voltak mindig, amit különben nem lehet csodálni”. A mindvégig meseként elöadott novella záró sorában a narrátor, mintegy az orális hagyomány követője, önmagát mesélőként feltüntetve szólal meg: „Ez a régi történet a három lányokról”.

A meseelemek e többszintü viszonyában a mesehagyománnyal, és a jelkép közvetítésével egymással is kapcsolatba kerülnek a novellák. A mesealakulatok esetében például magába a rövid történetbe beépülö mese, mint narratív szerkezet mutat ilyen jellegü vonásokat (ti. ezek révén kapcsolódnak össze a mese alaktani jegyeit különbözőképpen beépítő novellák). Csáthnál azonban mind az alaktani, mind a jelképértékű használat szempontjából redukálódik a mese funkciója, vagy legalábbis látható, felületi „ikonja” hangsúlyos. Az említett összegzőjelképként használt bagoly szó alkalmazásával párhuzamosan (pl.: Szombat este, Anyagyilkosság, Történet a három leányokról, A béka) - ami mindig a mese ilyen felfogásával összefüggésben, ösi mesehagyományt felidéző kontextusban jelenik meg -, máshol redukálódva, maga a mese szó veszi át ezt a szerepet.

Elgondolkodtató, hogy az olyan darabokban, mint az Anyagyilkosság, vagy A béka, amelyek hagyományosan az elbeszélői távolságtartás, hüvös, részletező tárgyilagosság mintapéldájaként kanonizálódtak, hogyan értelmezhetők a mesére tett apró utalások. Például az Anyagyilkosságban „a fájdalom misztériumának” megismerését szolgáló, jól előkészített (rituális!) állatkínzások csúcsát miért éppen egy bagoly elkapása jelentette? Mint az kiderül: „A bagoly régen érdekelte őket. A feje olyan, mint két nagy szem. Az

\footnotetext{
${ }^{150}$ Egységes világlátás nyomairól, illetve mese és szakralitás kapcsolatáról lásd pl.: BóDIs Zoltán: Mese és szakrális kommunikáció. In: BÁLINT Péter (szerk.): i. m. 137-159.
} 
agyában csodálatos régi mesék vannak elrejtve. Száz évnél is tovább él... Bagoly kellett, kellett..." ${ }^{151}$ Később pedig: „Arról beszéltek, hogy a madár tulajdonképpen csak egy ház, ahová a Kín beköltözött, és ott lakik, míg csak a baglyot meg nem ölik. De hol lakik? Minden valószínűség szerint a fejében.” Vagyis ott, ahol a „,csodálatos régi mesék” is, ez a ház, a korábbi üres hely együtt tartalmazza ezeket. Amit pedig kiadott magából „.... csontig ható, rémes hang, minden képzelőerőt felülmúlt” Ezután kap helyet a novellában a látszólag ettől idegen látomás elbeszélése, amit a nagyobbik Witman fiú „mesél”, s amit majd ketten szőnek tovább. E (bagolyhoz kapcsolódó, onnan eredő, immár közös) „tapasztalat” után mennek föl együtt a lányhoz. Nagyfiúkként már eltávolodtak a „boldog” gyermekkor időszakától ,amikor »mesével« korrigálni lehetett még a valóságot [...], s a vágy még meseként tudott realizálódni”. ${ }^{152}$ Vágykiélés így már nem a mesehallgatásban, hanem például a bagoly fejében lévő „mesékben”, egy lány megkínzásában, vagyis ezek által önmagukban találják meg, de még mindig a „mesék” médiumán keresztül.

Az Anyagyilkosság későbbi részletesen elemzését megelőzve, annyi talán belátható, hogy a mesei archaikumban meglévő felfogásra tett utalás, melyben nem vált még szét a valóság és vágy régiója, egészen más megvilágításba kerül a novella eseményeinek írói indoklása, miszerint „ha szép és egészséges gyermekeknek korán meghal az apjok, abból rendesen baj származik."

Felidézhető ugyanakkor a mesét mint realista szemléletü művészetet tárgyaló felfogás is, mely szerint a mesei fantasztikum ,jelképességével jól megfelel annak a művészi funkciójának, hogy a hallgató vágyait kifejezze, és pedig épp azzal, hogy nem a világot, hanem annak ellenképét tükrözi: a soha meg nem valósulható igazságot és rendet". ${ }^{153}$ Vagyis nem a hétköznapi társadalom szokásrendszere által befolyásolt „realitásokat” közvetíti, hanem a teljes egészében soha meg nem ismerhető igazságot, a mesékben megjelenő ősi rendet, melyben az ösztönök, vágyak még nem korlátozódtak. ${ }^{154}$ Ugyanakkor e reálisan előadott ,irreális módon brutális” cselekménynek a történet szintjén meglevő kontrasztja, éppen a novella és a jelkép (bagoly) felidézte mesehagyomány közti kontraszttal támasztható alá.

A korpusznak ezt a reális-irreális kettősségére épülö jellegét hangsúlyozza Dobos István egyik tanulmányában, amelyben arra is figyelmeztet, hogy Csáth „kísérteties

\footnotetext{
${ }_{152}^{151}$ Az alábbi idézetek mindegyike: CsáTH: Anyagyilkosság. = Uö.: i. m. 109-117.

${ }_{152}$ BORI Imre: A ,homo novus" nagysága és tragédiája. = Uö.: Varázslók és mákvirágok. Forum. Újvidék, 1979. 292.

${ }^{153}$ NAGY: i. m. 216.

${ }^{154}$ Vö. Slavoj ŽıžEK: Az inherens törvényszegés avagy a hatalom obszcenitása címủ tanulmányának reálisirreális ellentétére vonatkozó belátásaival, a reálissal ütköző oldal ehhez viszonyítva „irreálisabb”, de ettől nem feltétlenül ez kevésbé a „természetesebb”. Thalassa, 1997/1. 116-130.
} 
novelláit egyidejüleg írja az álom és valóság senkiföldjén játszódó történeteivel. Mivel magyarázható ez a kettősség?" Dobos István saját felvetésére adott válaszában kimondatlanul ugyan, de - éppen a mesék egyik jellemző vonását fogalmazza meg: „A lidérces elbeszélések valódi értelmét az a hátborzongató gondolati élmény adja, hogy a tapasztalaton túli szörnyüségek is az emberi lényeghez tartoznak. [...] a borzalom lényegében a mi létünkön alapul, tehát nem kísértet. Azért játszódnak a történetek lebegtetett valóságban, mert a feloldott tér- és idődimenziók érzékeltetik lényegüket”" ${ }^{155}$

Az Anyagyilkosságban, a novellába ekként beépülő, illetve az általa körülírt mese müfaját érintő jellegzetes vonások (reális-irreális viszony stb.) csak jelzésként, az írói világképpel összefüggésben jelentkeznek. Mégis, a kettő kontextuális viszonyában az ősibb, mitikus hagyományhoz kötődő mesejellemzők a befogadás és az interpretáció tekintetében legalább olyan súlyúnak bizonyulnak, mint a novelláéi. Egy kizárólag tárgyilagos szemléletű megközelítésben komoly „fennakadást” okozhatnának azok az apró következetlenségek, amelyek - ha a mesei fantasztikum felöl tekintünk a szövegekre magyarázhatóknak tűnnek. Ilyen figyelemre méltó „,apróság” az Anyagyilkosságban, hogy miután a Witman fiúk a padláson „magukhoz vettek egy vésôt, egy harapófogót, megvizsgálták a lámpást, és mindezt zsebrevágták” és lefeküdtek „Mikor végre a toronyóra lassan elverte az éjfélt, készülődni kezdtek. Meggyújtották a kislámpát, a fiatalabb Witman fiú a harapófogót, a reszelőt és a lámpát vette magához, a másik csak a hosszú pengéjü nyitott zsebkést”, vagyis a vésőből egy alapvetően más funkciójú, legfeljebb hasonló alakú eszköz lesz. ${ }^{156}$

Talán az sem véletlen, hogy hasonló „elírás” található a már idézett Történet a három leányokról címü Csáth-írásban is. A novella kezdetén az elbeszélő a lányok közötti egyetlen különbséget említve felsorolja: „Az első fekete, a második vörös, a legkisebb aranyszőke hajú.”. Majd nem sokkal ezután az első lány lovaggal való találkozásakor a fiú így köszön: „,- Jó reggelt, te szép barna lány”. ${ }^{157}$ Ezt a következetlenség a lovag színvakságán túl a novella fenti olvasata alapján is értelmezhető. Hiszen a nagy, mesei szemléletben meglevő ősi egység megszünésével elsőként a fekete hajú lány kezdett korábbi önmagától és testvéreitől (el)különbözni, kiválni abból a rendböl, amihez eddig tartozott.

\footnotetext{
${ }^{155}$ DoBos István: Racionalitás és misztikum. In: DÉR Zoltán (szerk.): i. m. 61.

${ }^{156}$ CSÁTH: Anyagyilkosság. = UÖ.: i. m. 115. [A kiemelés tölem. B. S.]

${ }^{157}$ CsÁth: Történet a három leányokról. = Uô.: i. m. 12-15. [A kiemelés tőlem. B. S.]
} 
Ezen kapcsolódási pont alapján egymással és a mesehagyomány egészével kontextuális, intertextuális viszonyba kerülő novellák így leginkább a mese műfajspecifikumai felől tünnek értelmezhetőknek. A szigorú szöveg- és műfajhatárok átjárhatóságát erősíti a Csáth-életmünek az a sajátsága, melyben az író a különböző művészeti területek (elsősorban az irodalom, a képzőművészet és a zene) együttes alkalmazására, jellemzőinek kölcsönös felhasználására tesz kísérletet. ${ }^{158}$

Nem véletlen, hogy Csáth éppen egy zenei tárgyú írásában, Grieg halála alkalmából idézi fel a norvég kultúrának és irodalmi- illetve mesehagyománynak az e zeneszerző müvészetét is meghatározó vonásait. Ibsen Peer Gyntjének és Grieg azonos címü suitejének közös hanghordozásáról szólva olyan mese-párhuzammal él, amely nemcsak például a Szombat este gyermeki látásmódjának szövegalakításába szürődik be, hanem a mese hagyományozó, nemzedékeket és kultúrát összekötő ,idegrendszerünkbe” férkőző vonásait is kiemeli. ${ }^{159}$

A Szombat estében is megfigyelhető ez a törekvés, érdekes módon éppen a mese műfaját érintő elemek alkalmazásával összefüggésben. „Míg Julcsa a mesét mondja, hallgatom a muzsikát is; mert mindkettőt jól ismerem. Nagyon szomorú zene, csak apa és anya szeretik. Mi nem.” A főhős Homokemberhez füződő disszonáns viszonyának megértésében tehát a jól ismert, cím szerint megemlített mesék és a „nem szeretem zene” „együtthallása” is nagy szerepet játszik. A különböző müvészeti ágak ekként elgondolt kölcsönös, köztes viszonya, az intermedialitás ${ }^{160}$ egyben ajánlatot tesz az ilyen típusú „szövegek” befogadására is. Ez pedig az „együtthallás”, „összeolvasás”.

Visszhang és áthangolás: mesehagyomány és figurativitás (Szombat este, Anyagyilkosság, A béka)

Csáth Géza Szombat este című elbeszélésének sokat idézett passzusában olvasható: „... De mégsem árnyék az, hanem a Homokember. Olyan, mint egy bagoly, és éppen, mintha apa

\footnotetext{
${ }^{158}$ SZAJBÉLY: i. m. 134-143., BORI Imre: A „homo novus” nagysága és tragédiája. = Uö.: i. m. 287.

159 „A falon komor árnyékok osonnak el halkan. Óriási macskák, hollók árnyai - a mesékből talán, amelyeket Aase valaha régen elmondott a fiának. Titokzatos, idegen világ ez, amelyet Ibsenből meg se értenénk, ha Grieg muzsikájával a szívünkbe és az idegrendszerünkbe nem férkőzött volna.” Vö: CsÁTH Géza: Grieg. = Uö.: A muzsika mesekertje. (Összegyüjtött írások a zenéről.) Szerk. és sajtó alá rend.: SZAJBÉLY Mihály. Magvető, Bp., 2000. 39-41.

${ }_{160} \mathrm{Az}$ intermedialitás fogalma a mai irodalomelméleti gondolkodásban pl. PETHÖ Ágnes (szerk.): Képátvitelek. (Tanulmányok az intermedialitás tárgyköréböl.) Scientia, Kolozsvár, 2002. A terminusról és a mások szövegeivel kapcsolatos felhasználhatóságáról bővebben: GYARMATI Krisztina: Esztétizmus és intermedialitás a századforduló prózájában. In: EISEMANN György (szerk.): A kánon peremén (Az irodalmi modernség alakváltozatai a XIX-XX. század fordulójának magyar prózájában). ELTE XVIIIXIX. Századi Magyar Irodalomtörténeti Tanszék, Bp., 1998. 61-71.
} 
ágyának peremén ülne. Borzasztó ránézni, mert hatalmas, félelmetes és csúnya ö". ${ }^{161} \mathrm{Ez}$, a Homokembernek és a bagolynak látszólag önkényes, ötletszerü (a bagoly nem mindenki számára, illetve a novella szövege alapján sem „hatalmas”, „félelmetes”) összekapcsolása leginkább Csáth más novelláinak egyes utalásai alapján érthető meg. (Anyagyilkosság, Történet a három leányokról, A béka) Azokból, ahol a bagoly szó egyértelmü(bb)en a meséhez, a mesének mint epikus hagyománynak a jellemzőihez kapcsolódik.

Így a Szombat este értelmezésekor sem elég a szöveg mesékhez kapcsolt felszíni utalásainak lexikális, életrajzi vonatkozásait regisztrálni, mint azt Lőrinczy Huba teszi $A$ homokember és Andersen bácsi címủ tanulmányában. ${ }^{162}$ A bezárt ajtók ellenőrzésének („Azután apa végigmegy gyertyával az összes szobákon. Megpróbálja, be van-e zárva az ajtó, visszajön.”) a novella korábbi részében például az apáról adott jellemzésből nem következő megemlítése és a Homokember szimbolizálta gyermeki félelemérzés tematikusan (pl.: az ott szereplő betörő, gyilkos manók bejövetelét akadályozandó stb.) A varázsló kertjéhez kötik a Szombat estét. A baljós sejtelmet éppen ezek: a bagoly mesei összegzö jelképe és a tematikus kapcsolatok révén egymással kontextuális viszonyba lépő novellák (is) indokolhatják.

Beszédmódjukban, illetve narratív és stilisztikai jellemzőikben jelentős különbségeket mutató írások kerülnek ebből a szempontból egymással szoros, esetenként szövegszerü kapcsolatba. Közös bennük a mesének a folyamatos beszédet, narrativitást a (szövegben)létezés ontológiai és textuális feltételévé emelő jellege, akárcsak az Ezeregyéjszaka meséinek archaikus, orális müfaji hagyományában.

Csáth „meséi” ebben a tekintetben is rosszul végződnek, mivel felborítják a szakirodalom ama tipológiáját, melyben jól elkülöníthetők egymástól „a hüvös tárgyilagossággal és metsző logikával” jellemezhető „lidérces” novellák (Anyagyilkosság) és az „álom és valóság között lebegő mesei stilizáltságú” elbeszélések (Varázsló kertje). ${ }^{163}$

A Csáth-szakirodalomban az említett kettősség ellenére is, mind az egyes elbeszélésekben érvényesülő stílusirányzatok, mind az beszédmód tekintetében bizonytalanság érezhető főként, hogy - miként arra Dobos István rámutat - az eltérő változatokat már csak azért is érdemes együtt szemlélni, mivel Csáth „kísérteties novelláit egyidejüleg írja az álom és

\footnotetext{
${ }^{161}$ Az alábbi idézetek mindegyike: CSÁTH: Szombat este. = Uö.: i. m. 38-41.

162 A Szombat este központi motívumának, a Homokembernek az elsődleges forrásaként általa megjelölt Der Sandmann című E. T. A. HofFMANN elbeszélés szintén sokszorosan kapcsolódik a mesehagyományhoz és ennek alapvető jellemzői nem függetleníthetők a szöveg értelmezésétől. Így e szövegnek a Szombat estét tematikusan magyarázó, egyirányú összekapcsolásánál fontosabbnak tünik mindkét írás esetében a mesehagyományhoz való dialogikus viszonyuk. Vö. LÖRINCZY Huba: A homokember és Andersen bácsi. = Uö.: Ambrustól Máraihoz. (Válogatott esszék, tanulmányok.) Isis könyvek, Eszmetörténeti könyvtár 4., Savaria University Press, Szombathely, 1997.

${ }^{163}$ Vö. DoBos István: Racionalitás és misztikum. In: DÉR Zoltán (szerk.): i. m. 60-61.
} 
valóság senkiföldjén játszódó” lírai hangvételü történeteivel. ${ }^{164}$

E filológiai alapozottságú belátás ellenére az említett tipizáláshoz sajnos óhatatlanul az az elképzelés társult, hogy a kétféle elbeszéléstípus hátterét adó művészeteszmény és elbeszélői hagyomány is alapvetően különböző. Az emberi pszichikum mélyéről fakadó, tárgyilagos előadásmódú novellák inkább drámaiak de csúnyák, míg a szecessziós meseelképzeléshez kapcsolt írások az elvágyódó, menekülést kereső ember közegét jelentik, vagyis líraiak és szépek. Ez utóbbi „meseelemekkel társult impresszionistaszimbolista novellák” egyik „hiányossága” Dér Zoltán szerint azonban az, hogy „,a szomjas képzelettel megalkotott álomvilág végül nemhogy kiforrná az emberi jelentést, inkább a mesés képzelgés természetéhez stilizálja". ${ }^{165}$

A béka tehát, akár az Anyagyilkosság, ebből a szempontból nem mese, stílus és előadásmód tekintetében is meglehetősen különbözni látszik, a címben vagy a témaválasztás miatt Csáth által meséknek titulált írásoktól. ${ }^{166}$

Ugyanakkor a mesélés, a mesemondás gesztusa, a mese szövegszerü tematizálása, az alvás, az álom beépülése szövegszervezö elemként vagy történetegységként; valamint a bagoly mint központi jelkép előfordulása ${ }^{167}$ - vagyis éppen a lírai hangvételü, mesei stilizáltságú novellák fő jellemzői - rokonítják egymással ezeket a más típusú szövegeket, így például a Varázsló kertjét a Szombat estét és az Anyagyilkosságot vagy A békát. A kérdés tehát mindenekelőtt az, hogy az elbeszélői távolságtartás, hüvös, részletező tárgyilagosság mintapéldájaként kanonizálódott novellákban miként értelmezhetők a mesére tett apró utalások, továbbá, hogy ezek kontextusa mennyiben befolyásolja a vele kapcsolatba kerülő szöveg értelmezését?

1.

Az Anyagyilkosság és a benne a másik cím szerint felbukkanó Csáth-novella, ${ }^{168}$ a Szombat este a szakirodalom szembeállító tipologizációja ellenére számos hasonlóságot mutat. Stiláris és narrációs különbözőségüknél így hangsúlyosabbnak tünik a meséhez való összetett viszonyuk, melyet tovább rétegez az E. T. A. Hoffmann Homokemberével

\footnotetext{
${ }^{164}$ Ua. 61.

${ }^{165}$ DÉR Zoltán: Többszólamú epika. $=$ Uö.: Ikercsillagok. Forum, Újvidék, 1980. 271.

${ }^{166}$ Vö. CsÁtH Géza: Mesék. = Uö.: i. m. 286., Mese az emberek rosszaságáról. = Uö.: i. m. 344-346., Mese a kávéházból. $=$ Uỏ.: i. m. 277-280.

${ }^{167}$ A mesei jelkép müködését és a bagoly szövegelem ezzel összefüggő felidéző szerepű, jelképértékủ használatát lásd: Körül-irás: a mese múfaji és tematikus elemei; a mesei jelképek című részében, a 40. oldaltól.

${ }^{168}$ (,....enni adott nekik, és tiszta alsót szombaton este”) Szóelemek értelmezhetősége, jelentősége Csáthnál lásd: SzITÁr Katalin: Szó és történetképzés Csáth Géza novelláiban. Schmith mézeskalácsos; Palincsay; Dénes Imre. In: GinTLI Tibor (szerk.): Változatok a modernitásra. Tanulmányok a Nyugatról. Anonymus, Bp., 2001. 178-191.
} 
létesíthető bonyolult intertextuális kapcsolatrendszer. ${ }^{169}$ A Szombat estében is meghatározó a mesének, a mesehallgatásnak a szocializáció folyamatában betöltött szerepe. A családi idill egyes szám első személyü elbeszélésébe beépülő tematizált meseelemek: a címükkel szereplő Grimm-mesék, ${ }^{170}$ vagy a mesei számmisztikából ismert emblematikus számjegyek (három füstkarika, három mese, hét szem cukor) mellett azonban fontosabbnak tűnnek azok az elbeszélés- és szemléletmódbeli elemek, amelyek leginkább a mese mint egyszerü forma műfajspecifikumai felől közelíthetők meg. A novella egészére kiterjedő, reálist-irreálist szembesítő oppozicionális szerkesztésmód, a szöveg lexikai és stiláris jegyein túl (ilyenkor - máskor, szombat este - a többi napon) leginkább a „főhős” disszonáns mivoltában jelentkezik. Az imitált gyermeki látásmóddal indokolt, korlátozódott narrátori omnipotencia következtében a korábbi megnyugtató ellenpontozást bizonytalanságérzet váltja fel. „De mégsem árnyék az, hanem a Homokember. Olyan, mint egy bagoly, és éppen mintha apa ágyának peremén ülne. Borzasztó ránézni, mert hatalmas, félelmetes és csúnya ö. S olyankor a fülünkre húzzuk ám a takaróinkat. Csak néha hajtjuk la a paplan csücskét, és azon át egy pillanatra még kinézünk."171

A elbeszélő magabiztosságát indokló hangsúlyozottan kifinomult érzékelési, valamint aprólékos megfigyelési képességét és így a történetmondáshoz szükséges éberséget és tisztánlátást lassanként elhomályosítja a címadó figura. ${ }^{172}$ „Míg Julcsa a mesét mondja, hallgatom a muzsikát is; mert mindkettőt jól ismerem”; másutt: „De nem jó elaludni mindjárt. Többször felnyitjuk a szemünket, mert a Homokember még nem jött”; továbbá: ,jól hallom, amikor apa később vizet önt magának" vagy a nagymama készülődésének leírásakor: „Hallani, amint kiveszi a cukortartóból a cukrokat. Megolvashatjuk, amint beledobálja a pohárba", mely utóbbi szóelem a megfigyelés textusbeli összetevőire (ti. történetté lesz) is rámutat. A korábbi biztonságot nyújtó percepciót felváltja a Homokembert kísérő kognitív dilemma. A hoffmanni előszövegből eredeztethető, ezen empirikus tapasztalatokat ellehetetlenítő jellege szempontjából meghatározó az a látszólag egyszerű megoldás, amely az alváshoz, az álomhoz kapcsolja

\footnotetext{
169 A Szombat este központi motívuma, a Homokember és a Der Sandmann címü E. T. A. HofFMANN elbeszélés szintén sokszorosan kapcsolódik a mesehagyományhoz, melynek alapvető jellemzői így nem függetleníthetők a szöveg értelmezésétől.

${ }^{170}$ Vö. Jakob GRIMM - Wilhelm GRIMM: Die sieben Raben, In: Kinder und Hausmärchen. Reclam, Ditzingen 1984. Band 3. 25.; und Der Eisenhans. In: Ua. Band 2. 233.

${ }^{171}$ A novellából vett idézetek mindegyike: CsÁTH Géza: Szombat este. = Uö.: i. m. 38-41. [A kiemelések tölem. B. S.]

172 „Ha azt mondom nektek: jön a Homokember, csak azt akarom mondani, hogy álmosak vagytok már, leragad a szemetek, mintha homokkal hintették volna tele.” E. T. A. HoffmanN: A homokember. Ford.: Barna Imre. Európa, Bp., 1997. 104.
} 
alakját. A Hoffmann-szöveget átszövő okuláris metaforika ${ }^{173}$ és a látvány egyértelmüségét felváltó alternatív valóságérzékelés interpretatív variabilitása ${ }^{174}$ sokban rokonítható a csáthi megoldásokkal. A Der Sandmann felöl különös hangsúlyt kap a nagymama azon intuitív beleérzőképessége, mely a Hoffmannál tematizált alkímiát idéző rituális cukorégetéskor, az elbeszélő kizárólagosnak vélt percipiális adottságainak alternatívájaként a szemüveg levételében - a narrátor-féle, egyeduralkodó látási képességet relativizálva - mutatkozik meg. „A rum lilás rózsaszínű lángocskákkal ég, és kicsapkod néha a csésze szélén túl is, a nagymama meg leteszi a szemüvegét, és mosolyogva nézi”. ${ }^{175}$

Mindezekkel összhangban az idő és értékszembesítő viszonyítottság jelen idejü tisztánlátását felváltja a jövőbeli beláthatatlanság: ,.... Homokember a falon megnyúlik, megnő: most már mindenkinek aludni kell. Apa azt mondja: - Holnap reggel magam veszek a piacon kelvirágot. Anya mond rá valamit, de azt már nem lehet hallani.” A korábbi biztosnak hitt narrátori percepciós képesség tehát felfüggesztődik, az empirikus helyét átveszi az imaginárius, a valósét a fiktív, az emlékezetét az álom. ${ }^{176}$ A rekonstruált ismétlődő történetet megakasztja a Homokember figurájának elhatalmasodása: „A Homokember, az óriás Homokember, az ágy peremén a falhoz húzódva, komolyan figyelve gubbaszt".

Ebben az olvasatban a „főhős” jelenléte nem magyarázható kizárólagosan a mesehangulattal átitatott gyermeki szemlélet lírai hangvételü felidézésével, melyben ,a gyermekkor tündéri világának írói újrateremtése nemegyszer a mese eszközeivel történt [...] a mesék csodálatos és varázslatos történetei révén” ezek segítségével ,kifejezve azt a nosztalgikus érzést, amelynek tárgya a gyermekkor vagy éppen az álmok, a képzelet birodalma volt."177 A Szombat este szövegszerü vizsgálatakor nem hagyható figyelmen kívül a mese poétikája szempontjából alapvető fontosságú, terminus értékű emlékezet szövegszervező funkciója. Walter Benjamin a mesemondás hagyománytörténeti jellemzőit

${ }^{173}$ Ezzel kapcsolatban lásd: Sigmund FreUD: A kísérteties. Ford.: Bókay Antal, Erős Ferenc. In: BÓKAY Antal, ERÖs Ferenc (szerk.): Pszichoanalizis és irodalomtudomány. Szöveggyüjtemény. Filum, Bp., 1998. 65-81.

${ }^{174}$ Ezen szemléletmód teoretikus összefüggéseivel kapcsolatban lásd: VIRÁG Zoltán: A szem erőpróbái és a tekintet üresedésrendje. = Uö.: A termékenység szövegtengere. (A regényíró Brasnyó István.) Forum Messzelátó, Újvidék - Szeged, 2000. 73-90.

${ }^{175}$ A látás, érzékelés és az álom, alvás halállal való tematikus összekapcsolása korán megjelenik Csáth gondolkodásában, Naplójában, a halálos beteg kishúga állapotának leírásakor leginkább a lány bandzsasága, testi változásainak zavaró részletei foglalkoztatják. Mindez, mintegy hasonló szituáció szövegvariánsa felidézi a Fekete csönd ide kötődő jellemzöit. Vö. ifj. BRENNER József (Csáth Géza): Napló (1901-1904) Közread., szerk.: DÉR Zoltán. Életjel - A szabadkai Szabadegyetem, Szabadka, 2007. 28-32.

${ }^{176}$ Vö. Wolfgang IsER: A fiktív és az imaginárius összjátéka. = Uö.: A fiktiv és az imaginárius. Ford.: Molnár Gábor Tamás. Osiris, Bp., 2001. 273-291.

${ }^{177}$ Pomogáts Béla: Búcsú az ifjúságtól (A Vörös Eszti címü elbeszélés szerkezeti elemei). In: DÉr Zoltán (szerk.): i. m. 106. 
tárgyalva utal a mese és az epikai emlékezet szoros kapcsolatára. Mnemoszüné mint a múzsák anyja, az epika szülője maga az emlékezés, mely megteremti a hagyományok láncolatát. „Valamennyi mesemondóban él egy-egy Seherezádé, aki a lepergetett mese fonalába mindig új meg új mese szálát ölti. Ez az epikus emlékezet, ez a mese múzsai jellege" ${ }^{178}$ mely egyben - tegyük hozzá - emlékezés magára a műfajra is, annak elbeszélői mintáira, szemléletmódbeli sajátságaira.

A Csáth-írásoknak a vágy és teljesülése kettőségében tetten érhető, emlékezésre épülő írói szemléletmódjára Bori Imre hívta fel a figyelmet: „az emberi test tudományával való barátkozás közben a »lélekkel« tud elsősorban szembenézni, s mi nem emlék vagy nem vágy, azzal valójában nem tud mit kezdeni". ${ }^{179}$ A Szombat este narrátora is folyamatosan korábbi szombat estékre emlékezik az egymásra következés metonimikus sora által szőve tovább történetét (,Szombat este, ó, az mindig a legszebb”).

Ezen emlékezethez kapcsolódó egynemü, metonimikus narratív eljárás éppen az említett idősíkok ütköztetésével párhuzamosan feltűnő, a temporalizáló metaforikához kapcsolódó Homokember figurával összefüggő más típusú szemlélet- és beszédmóddal ellenpontozva eredményezi a novella végére kialakuló disszonancia-érzetet. Ezáltal pedig fellazul a Szombat este említett egyensúlyi, homogenitásra törekvő metonimikus szerkezete és ennek helyét átvéve kialakul a mesehagyományhoz több szinten kötődő, heterogén, metaforikus szerveződésű elbeszélés. ${ }^{180}$ Miközben „a temporalizáló metafora az élő szó idejébe helyezi át mindazt, ami tőle eltérő."181 A Homokember mint az idilli, harmonikus nyugalmi állapotra balanszírozó szövegteret beárnyékoló figura (alakzat) retorikailag éppen asszociatív jellegü súlytalanságával billenti ki a tematikus szinten egyeduralkodó harmóniát.

$\mathrm{Az}$ eldönthetetlenség és határhelyzet metaforikus alakjaként, alakzataként a Homokember bagolyszerü jellemzése és viselkedése korántsem ötletszerüen esetleges, relevanciája a hoffmanni előszövegen túl a Csáth-életmü kontextusa felől, többek között az Anyagyilkosság hasonló szövegjellemzői felöl ítélhető meg.

\footnotetext{
${ }^{178}$ Walter Benjamin: A mesemondó. (Gondolatok Nyikolaj Leszkovról.) = Uö.: Kommentár és prófécia. Gondolat, Bp., 1969. 111-112.

179 BORI Imre: $A$,, homo novus” nagysága és tragédiája. = Uö.: i. m. 280.

${ }^{180}$ Vö. KulcsÁR SzABÓ Ernő: Metaforikusság és elbeszélés. = Uö.: Müalkotás - szöveg - hatás. Magvető, 1987. 57-93.

${ }^{181}$ THOMKA Beáta: Beszél egy hang (Elbeszélők, poétikák). Kijárat, Bp., 2001. 178.
} 
2.

„Witmannak két fia volt már, négy- és ötévesek, amikor egy napsugaras, csak kissé szeles novemberi délutánon búcsút mondott a világnak." - így indul maga az elbeszélés az Anyagyilkosság első, az eseményeket előrevetítő szentenciózus mondatát követően. ${ }^{182}$ A novella befejezésében pedig: „A fiúk ezzel búcsúztak és elsiettek az iskolába.” Ebben a búcsúzásban vajon az apa búcsúszava köszön vissza, ezt visszhangozzák a fiúk, vagy mindez csupán a szöveg narrátorának be- és leköszönő szava? A rejtély leginkább a tettesek kiléte, identitása és/vagy szubjektuma körül keresendő. Az apától eredő és a novella keretén belül az iskolában véget érő alakulástörténetnek láthatóan csupán egyik apró állomása az anya. A novella címe is inkább a hozzá kötődő, rajta végrehajtott cselekményt emeli ki, nem úgy, mint a Találkoztam anyámmal vagy az Apa és fiú esetében, jóllehet ezekben az írásokban is hagy a címszereplők jelenléte némi kívánnivalót maga után. Hiszen míg az előbbi az anya halálával indul, aki mintegy kísértetként tér vissza fiához, az utóbbiban az apa az anatómiai intézet szemléltető csontvázaként távozik fia karjaiban. ${ }^{183}$

Az Anyagyilkosság egyetlen név szerint megemlített szereplője Witman, az apa, és a gyerekek nemi identitásában is ez a szülői vonal öröklődik. A Witman-fiúk nevesítve is az ő fiai (Witman-fiúk) és „fekete kis szemeikben Witmannak, az apjoknak lelke csillogott”, Witmanné pedig az ő shakespeare-i recept szerint élö özvegye. („Gyarlóság, asszony a neved!’) Az apa neve és alakja árnyékolja be az egész novellát, és a hamleti dilemma megoldása egy pillanatra sem okoz gondot a fiúknak. Az ,akkor nemesb-e a lélek” etikai kérdése nem gyötri őket. Fegyvert ragadnak; egységben az erő!?

Elizabeth Badinter a férfiidentitásról írt cikkében említi, hogy a „homoszexuális és heteroszexuális férfiak egyaránt kétféle pszichológiai csonkulásnak vannak kitéve. Az első nőiességük amputációja. Ez eredményezi a kemény férfi-t, a macsót, aki sohasem békül meg az anyai értékekkel. A második a férfiasság hiánya, ami számos olyan férfinál figyelhető meg, aki apa nélkül nőtt fel, vagyis anyja egyedül nevelte.” A különböző kulturális variánsok egyik vagy másik oldalt erösítő jellege például az amerikai kultúrmodell esetében mára kitermelte a szuperhím ideálját: Rambo és Terminátor. „A férfias gépezet - írja Badinter - összehasonlíthatatlanul sérthetetlenebb, mint akár a legerősebb hím. Azt tenni, amit akarunk, és akkor, amikor akarjuk: ez a titkolt vágya a sok

\footnotetext{
${ }^{182}$ Ez és a novellából vett alábbi idézetek mindegyike: CsÁTH Géza: Anyagyilkosság. = Uö.: i. m. 109-117. [A kiemelések tőlem. B. S.]

${ }^{183}$ Vö. CsÁTH Géza: Találkoztam anyámmal. i. m. 26-27.; Apa és fiú. i. m. 83-85.
} 
férfiban ott szunnyadó kisfiúnak." "184 A két Witman-fiú: Rambo és Terminátor? Így értelmezhető a Anyagyilkosság harcászati arzenálja, militáris vetülete („Nyilak, gumipuskák és kések...”) és a fiúkról kapott frankensteini, netán robotikai jellemzés: „vékony és erős csontjaikon mint acéldrótok feszültek ki kicsiny izmaik"? ${ }^{185}$

A cselekvő apa tényleges jelenlétének hiánya, a bankhivatalnok szerető, aki „fiatal és szép gyerek volt” és a szintén ,gyerekszemü” se hal se hús anya minimális nevelőtevékenysége (,...enni adott nekik, és tiszta alsót szombaton este”) eredményezheti, hogy az egyidejüleg jelentkező kétféle amputáció (nőiesség és férfiasság) egyike sem tünik meghatározónak. A Witman-fiúk e köztes és megrekedt idetifikációs minták között, de mégiscsak szocializálódnak: például elsajátítják a nyelvet, és részt vesznek az intézményes oktatásban.

Kérdéses azonban, hogy mi jellemzi az így kialakuló szubjektumot és hogyan kapcsolódik mindez a meséhez?

Az Anyagyilkosságban a következő olvasható: „A bagoly régen érdekelte őket. A feje olyan, mint két nagy szem. Az agyában csodálatos régi mesék vannak elrejtve. Száz évnél is tovább él... Bagoly kellett, kellett..." A fiúk természetes szenvedélyévé vált állatkínzások csúcsát jelentő esemény ezen indoklása nem túl meggyőző, ha figyelembe vesszük, hogy a fiúkat mindeddig a „fájdalom misztériuma” érdekelte leginkább.

Vajon hogyan és miért kapcsolódik össze a bagoly fejében a kín és pusztulás a fiúk mese iránti vágyával? Azzal a felismeréssel, amit a nagyobbik fiú az első szexuális élményekor a bagollyal összefüggésben a következőképpen fogalmaz meg: „Witman fia a bagolyra gondolt, és átvillant az eszén az, hogy mindaz, ami az életben szép, nagyszerü és izgalmas, miért rettenetes, megmagyarázhatatlan és véres egyszersmind."

„Witman fia a bagolyra gondolt...” - arra a bagolyra, mely elképzelésükben „csak egy ház, ahová a Kín beköltözött, és ott lakik, míg csak a baglyot meg nem ölik. De hol lakik? Minden valószínűség szerint a fejében.” Vagyis éppen ott, ahol „az agyában a csodálatos régi mesék vannak elrejtve”. Mese és kín hasonlóságon alapuló metaforikus összekapcsolásában képzelet és valós, vágyott és reális kerül egyidejűleg egy helyre. Mindez egy olyan alternatív valóság keretén belül értelmezhető, amely alapvetően az „élet”, a fiúk életének társadalmiasult szabályaival és szociális körülményeivel állítható szembe. Ezt az alternatív valóságmodellt képviselheti a mese, mely epikus gyökereivel szakrális funkciójának elhalása ellenére is - számos rituális és mágikus elemet őriz, és

\footnotetext{
${ }^{184}$ Elizabeth BADINTER: XY, avagy a férfiidentitásról. Cafe Babel, 1994/1-2. 171-172.

${ }^{185}$ CsÁth Géza: Anyagyilkosság. = Uö.: i. m. 110.
} 
ontológiai státusánál fogva egyaránt kötődik az archaikumhoz, ${ }^{186}$ valamint a novellában a kezdetet, az eredetet jelölö apa nevéhez: „Witman fia a bagolyra gondolt...”

Király Jenő a mesevilág ontológiájáról szólva utal arra, hogy „a mítoszok és mesék a lét titkos történelmét adják elő”, az ezek rekonstruálását végző fantáziatevékenységből adódó élmény pedig ,a létezés olyan összefüggéseihez nyúl vissza, melynek az empirikus természet közvetlensége is csak megnyilvánulása”. A tapasztalati környezet tényeiből, élményeiből táplálkozó tudás a legutoljára fér hozzá - írja Király Jenő - „az összjátékhoz, mely a fantáziának már kiindulópontja.” Majd megállapítja: „Minden torzulás és szenvedés lényege a kiszakadás eme összjátékból, mellyel a legközvetlenebb kapcsolat közvetítöje éppen ősfantáziánk."187

Csáth e „tapasztalaton túli”, megnevezhetetlen dolgok egyik megoldásaként a mesét mint mitikus hagyományt jelöli ki, mely a maga módján kezelni tudta az elképzelhetetlen szörnyüségeket. Ezek, ha nem is tüntek befolyásolhatóknak, megváltoztathatóknak, mégis csupán felismerésükkel és megnevezésükkel az ember közelebb került a „legyőzésükhöz”. ${ }^{188}$ Említett írásai esetében is úgy tünik, hogy a novella fabulája a korhoz igazodva hétköznapi realitásokra épül, ugyanakkor a szüzsé a nyelvi sajátságaival, gondolati sémájával felidézheti a valamikori fantasztikumot. „A történet pedig, amely valamikor a realitás és irrealitás kontrasztos technikájára épült, már csak a reáliát örizte meg". ${ }^{189}$

A Cirkuszmulatság címü esszében az embernek a nem-természetes iránti vonzalmáról leírtak alapján - a csáth-i elképzelést követve - megállapítható, hogy az emberi gondolkodás is ekként őriz bizonyos ősi elemeket, többek között a valamikori mitikus világlátás nyomait. A nyelv emlékezete: ez az, amit Kosztolányi is megfogalmazott. Hasonló szerepet kap a mesei jelkép mintájára müködő mese szó Csáth novelláinak olvasási folyamatában. Ekként a mese is „,visszavágyás az ősállapotba, amely korántsem komoly csak olyan halvány föléledő emlék”. ${ }^{190}$ Így (is) érthető a fejezet Mészöly-mottója, melyben a mese „a legcsillogóbb »árnyék« rajtunk és bennünk”. Ugyanakkor a Cirkuszmulatság logikájához is az ily módon felfogott mese szolgáltathat gondolati alapot.

Csáth furcsának, irreálisnak titulált, és ezért a vágyak, álmok és mesék régiójába

\footnotetext{
${ }^{186}$ Vö. Jelezar MeletyinszKIJ: Mítosz, mese, eposz. = Uö.: i. m. 338-356. Különösen a 341., 346.

${ }^{187}$ KIRÁLY Jenő: Frivol múzsa, i. m. 247-249.

${ }_{188}$ A mitikus világlátás ezen törekvéseiről és nyomairól a mesében lásd: NAGY: Táltos és pegazus. i. m. 40.

${ }^{189}$ NAGY: i. m. 243. A fogalmak használatáról lásd: DoBOs: Alaktan és értelmezéstörténet, i. m. 115. illetve THOMKA Beáta: A pillanat formái, i. m. 200.

190 Vö. „Gyönyörködés abban, ami valamikor természetes és normális volt, most pedig innormális. A visszavágyás az ősállapotba, amely korántsem komoly csak olyan halvány föléledő emlék.” (CSÁTH: Cirkuszmulatság. = Uö.: Rejtelmek labirintusában. i. m. 13-14.)
} 
utalt, vagy kizárólag tematikusan e fogalmakhoz kapcsolt novellái a mese müfajával összefüggésben éppen a mese mint jelkép által megidézett valamikori ősi felfogásra épülnek, amelyben a csoda és irrealitás magától értetődőnek számít. A torzszülöttek másik belátása is éppen ez, hogy a fiktív, teremtett világ „valóságának a határait” a realitás jelöli ki. ${ }^{191}$

A Witman-fiúk kifinomult, módszeres tevékenységük során szerzett tapasztalatai kezdetben teljességgel nélkülözik ezt a fantáziát, a vágyuk kielégítésének feltétele mindig egy újabb áldozat. A testvérpár élményvilága is kizárólag a környezetükkel érintkezve, a megtapasztalás, birtokbavétel és megsemmisítés sorozatában bontakozott ki, mellőzve a mese által közvetített teljesebb tudást, léttapasztalatot. A zsákmányolt állatok sorát megkoronázó bagoly elodázott élveboncolása, és a viviszekciót kísérő izgalmi állapot (melyhez hozzájárult a bagoly fejében lévő titok, a mese elérési lehetősége) e szempontból központi jelentőségü a novellában („Valóban, izgatottan vetkőztek le [...]. Úgy érezték, hogy valami feszes ruganyosság szállja meg a tagjaikat, mintha a lekötözött, vonagló állat hiába pazarolt ereje, feléjük, rájuk suhanna.”). A felfokozott tudatállapot egyik kísérőjelenségeként értelmezhető álombetét teljessége, kozmikus, mindent átfogó volta mellett (,Ami szenvedés csak lehetett a földön, mind ott vonaglott, sikoltott és üvöltött a lovak patái alatt”) eltörpül az ezt kiváltó tett: viszonylag hamar és mechanikusan végeznek a bagollyal.

Dér Zoltán a novellista Csáthról szólva jegyzi meg, hogy a mese az álom „elöadásának, fölidézésének közlésformája lett”, és elvesztve eredendő naivságát válhatott éppen a „belső végtelen” elérésének egyik eszközévé. ${ }^{192}$ Majd az Egyiptomi József címü Csáth-elbeszélés átdolgozott változatát méltatva felhívja a figyelmet az író által a korábbi egyszerü keretes álomleírás elé illesztett elmélkedő rész fontosságára. Itt írja Csáth: „Az álom reális dolog, életérték, megbecsülendő finom elmemunka, akár valami szép vers vagy mese, ami közvetlen és szinte lemérhető élvezetet szerez."

Ezt az élvezetet hajszolták és találták volna meg a Witman-fiúk a bagoly fejében? Így érthető a gyors mechanikus kivégzést követő narrátori megjegyzés, hogy „egészében nagyon meg voltak elégedve, a dolog megérte a fáradságot”? Ezek után pedig aznap délután először ,az idősebb fiú egyedül ment el hazulról” és megismerkedik Irénnel, kivel ugyan hamar ráun a hancurra, de - mint megtudjuk - nevét ,igen szépnek találta”. Az örökölt apai név és a szintén e nevet viselő özvegy után szembesül az első tőle különböző nevü, differenciált szubjektummal, a NÖ-vel. A hozzá kötődő szadisztikus testi

\footnotetext{
${ }^{191}$ Vö. CsÁTH: A torzszülöttek. = Uö.: Rejtelmek labirintusában. i. m. 315.

192 DÉr Zoltán: Többszólamú epika. = UÖ.: Ikercsillagok. Forum, Újvidék, 1980. 240.

${ }^{193}$ Ua: i. m. 284. Vö. CsÁth Géza: Egyiptomi József. In: Híd 1976/5. 670-673. [A kiemelés tölem. B. S.]
} 
kapcsolatuk is inkább e különbözőség felismerésében és ennek megtapasztalásában keresendő, ${ }^{194}$ mely során az eddigi metonimikus egymásra következést (zsákmányolt állatok sora) felváltja a korábbi vágykiélési minták hasonlóságon alapuló funkcionális helyettesítése. „A nyers szexualitás nemcsak egy tárgyhoz, konkrét partnerhez, de még meghatározott tárgytípushoz sem ragaszkodik. Az ösztön nem a tárgyat, csak az aktivitás homályos képét, a törekvés struktúráját határozza meg, amelyhez hozzá kell keresni a kibontakozás adekvát tárgyi feltételeit." - jellemzi ezen szocializációs stádiumot Király Jenő könyvének szexuálesztétikai részében. ${ }^{195}$ Irénhez füződő viszonyukban már nem kizárólag az ismétlési elv vezérli őket, nem a tartalmi egymásra következés, hanem a funkcionális hasonlóság indokolja az örömszerzési formáik egymásra épülését, mely az ezen relációra épülő retorikai müvelettel nyelvileg is leírhatóvá válik. („Ebéd után a szobájukba zárkóztak, és a leányról beszéltek...”)

A mesélő eljárás axiomatikája és a fikcionalitás irodalmi formáinak a szempontjából lényeges a mese ezen alternatív valóságmodellhez kötődő, a freudi pszichológiában a tudattalanhoz kapcsolódó, primer létélményt felidéző, animisztikus jellege. Az apa a névhasználaton túl a két fiú 'kiswitmani' egységében is folyton ott kísért a novellában. Például pont olyan „szeles őszi estéken” indulnak beszerzőkörútjukra a fiúk, mint amilyen „kissé szeles novemberi délutánon” az apjuk meghalt. Király Jenő is említi, hogy a mesében hagyományozódó, vagyis öröklött bölcsesség ,nem úgy müködik, mint az egyéni mérlegelés, ősi élmények értelmezik egymást és az újakat. [...] Élők és holtak beszélgetnek."196 Netán, Witman és a fiai?!

\section{3.}

„Sikerült. Csillogott a szemük, - értesülünk a bagoly elkapásáról - és erös vállaikban egy férfi erejét érezték.” Az apjukét, persze főként, hogy „fekete kis szemeikben Witmannak, az apjoknak lelke csillogott”. És a bagoly feje is, mely „olyan, mint két nagy szem” őt rejti csodálatos régi meséiben? „A szemeit szedték ki előbb, aztán a mellkast bontották föl, most már felszabadítva a madár száját, mert a hangját akarták hallani. Ez a hang, ez a csontig ható, rémes hang, minden képzelőerőt felülmúlt...” Valóban ennyire számottevő

\footnotetext{
${ }^{194}$ Annál is inkább, hiszen az újabb posztanalitikus elméletek szerint a „szadista-mazochista” pár a nemi praxis során korántsem alkot harmonikus egységet. „....a tagadás két ellentétes modalitásával van dolgunk: a szadizmusban a közvetlen negációval, erőszakos pusztítással és kínzással találkozunk, ezzel szemben a mazochizmusban a negáció a letagadás formáját ölti, vagyis a színlelést, egy »mintha« tettetését, mely felfüggeszti a valóságot." Slavoj ŽIŽEK: Lovagi szerelem és síró játék. Magyar Lettre, 1997/nyár, 51.

195 KIRÁLY Jenö: i. m. 798.

${ }^{196}$ Ua. 248.
} 
volna az apa hiányként jelentkező állandó jelenléte?

Szajbély Mihály Csáth-monográfiájában a freudi tanokra alapozva javarészt az apa hiányával magyarázza az Anyagyilkosságot. A gyermekkor a vágyait mindenáron kielégíteni igyekvő ősi én birodalma, melyet a neveléssel párhuzamosan elsajátított szociális minták nyomán kialakuló felettes én szabályoz. Azt a szerepet - írja Freud -, amelyet később a felettes én vesz át, eleinte egy külső hatalom, a szülői tekintély játssza."197 Mivel pedig mindez sem a halott apának, sem a gyengekezű anyának nem állt módjában, a fiúkban feltörő ősi ösztönök kerekedtek felül. De mi közvetítődik az apát idéző, vele egyazon helyre került mesében, és kié a „csontig ható, rémes hang”?

Slavoj Žižek szlovén filozófus szerint „az íratlan szabályoknak, ennek a homályos törvényen kívüli területének az eredendően vokális státusza" sokat elárul a hangról. A saját beszédünk hallgatása - írja a szerző - „megalapozza a beszélő szubjektum áttetsző jelenvalóságának illúzióját, azonban nem a hang-e az, ami aláaknázza, méghozzá a legradikálisabb módon a szubjektum jelenlétét és transzparenciáját? Hallom magamat beszélni, de akit hallok, az soha nem teljesen azonos önmagammal [...]. Ez a bennem lévő idegen különböző megnyilvánulási formákban nyer alakot... " Alien, A nyolcadik utas: a halál - vetődik fel a Žižektől korántsem távoli asszociáció, de megelőz bennünket: „,igaz, hogy a hang élő jellege szembeállítható a beszéd halott betűivel, azonban ez egy el nem pusztult szörny rejtélyes élete, nem a Jelentés »egészséges« élő jelenléte..." "198

A Witman-fiúk tüntető némasága („Keveset és csak egymás között beszéltek”, a lekötött baglyot „,szótlanul bámulták”, az Irénnel történtekről pedig „,nem esett szó”) és a rémes hang kitartó kutatásának és élvezetének a kettőssége az Anyagyilkosságban vajon nem állítható-e párhuzamba a hal(l)ott beszéd és élö hang kettősségével? E szempontból érdemes figyelembe venni, hogy Bori Imre a tárgyias előadásmóddal íródott novellák újszerüségéről szólva a zenében véli felfedezni ezek alapját „Ha van visszatérési lehetőség a zene őskorszakába a »minden szakasz és ritmus nélküli« hosszú hangsorokkal, lennie kell az irodalmi őskorszakba is." 199

A feltett kérdésre adható egyik lehetséges választ talán épp a mese jelenti, mely a žižeki vokális státuszú íratlan szabályokhoz is sokban kötődik. David Riesman szociológiai munkájában a karakterformáló tényezőként müködő mese hatalmi szabályozójellege hangsúlyozódik. Mint írja, a tradíciótól irányított kultúrák gyakran „intézményesítenek

\footnotetext{
${ }^{197}$ Idézi: SzAJBÉLy Mihály: Csáth Géza. Gondolat, Bp., 1989. 204.

198 Az idézetek mindegyike: Slavoj ŽIŽEK: Az inherens törvényszegés avagy a hatalom obszcenitása. Thalassa, 1997/1. 116-130. [A kiemelések tölem. B. S.]

${ }^{199}$ BORI Imre: $A$, homo novus” nagysága és tragédiája. = Uö.: i. m. 287.
} 
bizonyos mértékű lázadást”, mely mindenki számára hozzáférhető. Így „,ahogy a kultúra a fantázia újabb és újabb területeit nyitja meg a lázadás számára, úgy fokozódik a mesének [...] kettős társadalmasító funkciója". Egyrészt viselkedési mintákat mutat föl, másrészt legitimál bizonyos mértékü lázadást a negatív hősök példáján keresztül, ezáltal elősegíti, hogy a fiatalok ,tiltott ösztöneiket emberi természetük és örökségük részének lássák, s ezáltal személyiségükkel összhangba hozzák", 200

Žižek gondolatmenetében a hang éppen a rendszeren, a társadalmi renden belüli devianciát, szabályszegést képviseli, melynek kordában tartása csak úgy lehetséges, ha „megkíséreljük visszaszorítani, szabályozni, alárendelni az artikulált SZÓnak, azonban figyelmeztet Žižek a riesmani elképzeléssel összhangban - teljes mértékig nem tudjuk nélkülözni, mivel megfelelő adagja szükséges a hatalomgyakorláshoz”.

Ehhez a SZÓ által szabályozott artikulációhoz képest jelenthet alternatívát az a Witman-fiúk által kidolgozott és használt kommunikációs mód, melyben nagy szerep jut a képzeletnek és a fantáziának, a borzalmas tapasztalatok útján megszerzett, de a mesei ősfantáziával összekapcsolódó élményekkel összhangban. Eme saját, testre/testből szabott nyelvük írható viszonylag pontosan körül Csáth Sassy Attilla rajzairól írt képzőmüvészeti esszéjének szavaival: „Müvészetük legmélyebb lényege egy titkos nyelvhez hasonlítható, amelyet hosszú esztendők alatt csak a maguk hasznára eszeltek ki új betűkkel, új szótárral és új grammatikával." ${ }^{201} \mathrm{Ez}$ a titkos nyelv érvényesül a nagyobbik fiú által mesélt látomásban, mely konkrét fiziológiai hatást gyakorol testvérére ,az öccse jelentette, hogy szintén érzi az asszonyokat", és ez idéződik meg a lány megkínzására jelt adó tekintetükben: „A fiúknak egymásra villant a szemük. Mind a ketten ütni kezdték”.

Ekként érthető, hogy bár a Witman-fiúk kedvükre tizedelik a város állatállományát, prostituáltat kínoznak, de közben azért gimnáziumba járnak, és semmi családlátogatás vagy igazgatói. „Amit a szubjektum ténylegesen akar, az egy, a szabadság, a szabad választás képében megjelenő parancs engedelmeskedni akar, azonban egyidejüleg a szabadság látszatát is fenn akarja tartani, hogy a saját arcát megőrizze" ${ }^{202}$ - fogalmaz Žižek.

Míg a riesmani modellben, a mese optimális szocializációs összhang elérését biztosította, addig az Anyagyilkosságban a bagoly fejében egyaránt fellelt régi mesék és a „csontig ható, rémes hang” együttes jelenléte éppen a disszonanciát, az alakuló szubjektum köztes és ellentmondásos állapotát, valamint ,,a nyilvános ideológiai diszkurzus és annak

\footnotetext{
${ }^{200}$ David RiESMAN: A mese és a technika; a karakterformáló tényezők alakulása. = Uö.: i. m. 151-152.

${ }^{201}$ Idézi: TOLNAI Ottó: Útban a képzömüvész felé. In: DÉR Zoltán (szerk.): i. m. 179.

${ }^{202}$ Slavoj ŽIŽEK: i. m. 124.
} 
fantáziabeli homályos mása közti minimális távolság"203 csökkenését visszhangozza.

A bagoly médiumán keresztül megtapasztalt, „minden képzelőerőt” felülmúló ősfantáziával érintkezve a Witman-fiúk képessé váltak éber állapotukban is e fantázialogika müködtetésére, mely fokozatosan átveszi a viviszekciók biztosította tapasztalati élmények helyét. Az empirikus élmények átélését rendre ezek narratív rekonstruálása követi a novellában. A fiúk kezdetben szükszavúan, majd a bagoly figurájának fel- és megismerésekor, valamint a NÖ-vel való testi érintkezés felfokozott élményszerüségét kísérő, de arról leváló, fokozódó bőbeszédűséggel. A lánnyal, mint nemileg és névileg különböző szubjektummal való találkozásuk ezt követően a nemi identifikáción túl a szimbolikus rendbe való belépés, a nyelvhasználat társadalmiasult formáinak, és müfajilag hagyományozódó mintáinak az elsajátítása szempontjából is meghatározó. „A történtekről nem esett szó. A nagyobbik azt mesélte, hogy a levegőben lények laknak, amelyek az emberekhez hasonlítanak..."

A tapasztalat retorikai helyettesítésének müvelete a mesehagyományhoz való baglyon keresztüli intuitív hozzáférhetőséggel társulva teszi képessé a Witman-fiúkat valós-fiktív, empirikus-imaginárius kettősségében rejlő nyelvi lehetőségek átélésére. E szempontból közömbös, hogy „valóban”, a tematikus szinten realizálódva történik-e meg az anyagyilkosság, vagy egyszerüen helyettesítődik a verbális leképezésével kialakuló narratív imaginációval. A fiúk, miután mindent előkészítettek, „lefeküdtek” és „suttogva tervezgették” a továbbiakat, a külső zajok azonban „nem rövidítették meg az órák lassú múlását”. Az ezután következő bekezdés „mikor végre a toronyóra...” kezdetű narrátori szövegrészéből röviden, lényegre törően értesülünk a gyilkosságról. Az egy-egy monologikus szereplői megjegyzéstől eltekintve végig a narrátor beszél - szólamában pedig nyoma sincs a fiúk által korábban egymásnak mesélt látomások intenzitásának és az ezt kísérő empirikus átéltségnek (,az öccse jelentette, hogy szintén érzi az asszonyokat”) majd, mintegy kiegészítve a korábban félbehagyott történetet, végül visszatér a kiinduló állapot leírására, és ennek temporális vetületére: „pár pillanat múlva már mind a ketten mélyen aludtak”. Ezt követően nem könnyen és maguktól „,ugrottak ki az ágyból”, miként a bagoly kivégzésének reggelén, hanem mély álmukból „reggel a takarítónő ébresztette fel őket”, „és eltüntek, zsebeikben a kincsekkel”. Arról azonban, hogy mik ezek, és hány darab van belölük csak korábban, a narrátortól értesülünk, miként a holttestről és a gyilkosság következményéről sem derül ki semmi (nem úgy, mint például Kosztolányi Dezső Édes Annájának befejezésével). A lefekvés és az ébredés között előadott ${ }^{203}$ Ua. 126. 
anyagyilkosság, így a korábbi vágyálmok és fantáziatörténetek mintájára, betétként épül a novellába. Ami még meghatározóbb az anyagyilkosság tettének narratív megokoltsága szempontjából, hogy az ezután meglátogatott lány se nem érzékeli, se nem értékeli a fiúktól kapott várva-várt kincseket. Annak ellenére, hogy állítólag a fiúk „előszedték a zsebeikből a drágaságokat”, majd „rárakták a hasára, a melleire, a combjaira”, a nagy nehezen magához térő lány csak a fiúkat látja, a látogatást köszöni meg, mint bármely, ezt megelőző üres kézzel tett alkalommal. A kapott ajándékokról tudomást sem véve, mintha mi sem történt volna, a testét befedő rengeteg ékszer dacára „befele fordult” és tovább alszik. A novella így végül tematikusan is az említett szövegspecifikumokat kísérő poétikai határhelyzethez és narratív disszonanciához közelít. Az Anyagyilkosságban ,árvákká lett” Witman-fiúk pedig az anyai névtől függetlenedve folytatják az ingázást az iskola és a bordélyház között.

\section{4.}

„Egy hang, amely gyereksíráshoz és elkínzott állat nyögéséhez hasonló. [...] Mintha valami kitépett szárnyú vén bagoly üvöltene az éjszakába az elmúlásról." - olvasható $A$ béka címü Csáth-novellában, mely témáját tekintve „a vágyképzet köré szerveződik”,204 előadásmódját pedig ,,a beteges ösztönök tárgyilagos” szemlélete és ábrázolása ${ }^{205}$ jellemzi. Pszichoanalitikus novella, a Fekete csönd, Kisasszony, Gyilkosság vagy a Fekete kutya mellett „,a freudizmus erős hatásáról tanúskodó, ${ }^{206}$ Csáth-elbeszélések egyike; így tehát ez sem „,mese”. Ennek ellenére épp a mesehagyomány jelenléte alapján rokonítható mind a Szombat estével, mind pedig az Anyagyilkossággal.

A béka elbeszélői alapszituációja és oppozicionális szerkezete a Szombat este említett jellemzői révén értelmezhető, ugyanakkor egy a gyermeki naivitást imitáló hangvételt felváltó, meggyőzésre törekvő, távolságtartó beszédmóddal indokolt polémikus szólammal egészül ki. A reális-irreális együttes jelenlétéből adódó kettősség mellett az emlékezés itt közvetlenül az elbeszélés szituációjának disszonáns okaként említődik: „ha csak ráemlékezem is a dologra, reszkető félelem fog el”, vagy poétikusabban „két békaszem pislogó, rohadt fényét látom a múltból az agyvelőmbe világolni”, ${ }^{207}$

Az álom irrealitást legitimáló volta, az ébrenléti állapot és a számolásban jelentkező perceptív és kognitív éberség hangsúlyozásával küszöbölődik ki, összhangban a Szombat

\footnotetext{
${ }^{204}$ BORI Imre: $A$,,homo novus” nagysága és tragédiája. = UÖ.: i. m. 278.

205 DÉR Zoltán: i. m. 242.

${ }^{206}$ DoBos István: Racionalitás és misztikum. In: DÉR Zoltán (szerk.): i. m. 64.

${ }^{207}$ Az alábbi idézetek mindegyike: CsÁTH Géza: $A$ béka. = UÖ.: i. m. 47-50.
} 
este említett „,megolvasásával”. Ebből a szempontból érdekes, hogy a Szombat este ezen textuális kifejezéséhez hasonlóan érthető $A$ béka narrátorának „olvasok magamban” (ön)kifejezése, mely a pszichoanalízis terapeutikai gyakorlata mellett önreflexív felhangot kap. („Elöször szabadulni próbálok tőle, olvasok magamban. Számokat adok és szorzok össze...) A természettudományos érvrendszer, valamint a mese és hiedelemmondák mint egyszerü formák éles szembeállítására épülő meggyőzés-retorikát (,,akkor egy pillanatig se hittem a dolgot, végre is az ember nem hiszi el a meséket”) a novella végére negálja az irreálist indokló realisztikus állítás. „Önök most azt mondják, kérem, hogy álmodtam. Tudják meg tehát, hogy a feleségem a nap után két hétre kiterítve feküdt.”

A „főhősnek” a béka ezen köztes állapotban levő, két (reális-irreális, valós-fiktív) szféra határán elhelyezkedő figurájával folytatott, népmesei alapozású, heroisztikus küzdelmének részletes leírásában a tematikus hasonlóságok mellett figyelemre méltó, hogy a végletekig fokozott intenzitásnak, hiperérzékenységü percepciónak hátterében nem világmegváltó küldetés, a felbecsülhetetlen jutalom elnyerése, hanem egy gyakorlati cél „a csontig ható rémes hang" megszüntetése áll. Azé a hangé, melynek elviselhetetlen diszharmóniája - miként az Anyagyilkosságban - a novella ellentétező egyensúlyát borítja fel, a jótékonyan egynemü elbeszélésszerkezetbe szól bele a mesehagyomány jelenlétéröl tanúskodva. A béka elpusztításához füződő mese realizálódásával így ezúttal is a határhelyzet bizonytalansága, az elbeszélői mindentudás metonimikus kiszámíthatóságát aláásó asszociatív kalkulálhatatlanság retorikai közege, a metaforikus szerveződésű elbeszélőszerkezet győzedelmeskedik. A narrátor által fizikálisan megszüntetett hang akusztikai ambivalenciája az elbeszélés retorikai szólamában terjed tovább. A disszonancia különböző módon, de egyaránt a mese ilyetén jellemzőihez rendelődő folyamatos fenntartása felől értelmezhető az Anyagyilkosságot is meghatározó ama köztes állapot, mely határhelyzetnek köszönhetően ezek a „mesék” rendre rosszul végződnek.

5.

„S e pillanatban hang üti meg a fülemet. Egy hang, amely gyereksíráshoz és elkínzott állat nyögéséhez hasonló.” A bagoly artikulálatlan állati sikolya a hasonlóság relációjában nem csak a kisgyermekére emlékeztet, hanem arra a tényre is, hogy ez, miként a mese alapvető jellemzői, a szocializációt és így a társadalmi rendbe való belépést megelőző ősállapotból származik. A saját hangjukat, miként nevüket mellőző fiúk ezen hangon keresztül „adnak arcot nevüknek", artikulálják azt, és így megképzik szubjektumukat, amely még és már nem a szimbolikus rendet szolgáló nevesített parancsot teljesítő harcos vagy katona, hanem 
egy alakulófélben és folyamatban lévő szubjektum. Mely, éppen ezért nem irható le a normális-abnormális, egészséges-beteges oppozíciókkal. Tudvalevőleg a Csáth korában Magyarországon kibontakozó ,pszichoanalitikus szemlélet pozitív hatása leginkább abban mutatkozott meg, hogy elmosta a határt »egészséges« és »pszichotikus« megnyilvánulások között”208 „A racionálisan gondolkodó Csáth az emberi létezés alapadottságának tekintette a disszonanciát, az ambivalenciát. [...] A lidérces elbeszélések valódi értelmét az a hátborzongató gondolati élmény adja - írja Dobos István -, hogy a tapasztalaton túli szörnyüségek is az emberi lényeghez tartoznak". ${ }^{209}$

„Álom valamely állat kínzásáról, amikor az állat rémesen megnő és borzasztó hangot ad. [...] Az állatot látom kifeszülni, hallom az üvöltést és látom a kidülledt, rémes szemeit" - olvasható Csáth 1915. augusztus 3-ai önanalitikus naplóbejegyzése. A pszichoanalitikus terapeutikai gyakorlat, a folyamatos mesélés és meséltetés nem kizárólag a gyógykezelés oldaláról jelent kihívást, az eközben felrémlő nyelvhasználati probléma, ${ }^{210}$ nem függetleníthető a posztanalitikus elméletek egyik alapvető kérdéskörétől: a tudattalannak a nyelvhez és a szimbolikus viselkedéshez való viszonyától sem, melyben az egyedfejlődés során az emberben kialakuló jelentéstulajdonítási bizonytalanság, a szignifikációs viszonyok elsődleges jelentőségűek. Az eközben felszínre kerülő lételméleti kérdések során szembesülnek ezen egyidejü, intenzív és egymást feltételező tapasztalatok, és a mese képviselte ősfantázia óhatatlanul felszínre hozza az elfojtott alapdilemmát. Éppen ennek a határhelyzetnek és a disszonancia poétikájának megmutatkozása felől látható be a gyötrelem és szenvedés nyelvi formái megtalálásának fontossága, ${ }^{211}$ vagy az Anyagyilkosság kapcsán felvetődött Ambrose Bierce-párhuzam, és Tolnai Ottó ama észrevétele is, hogy Csáth megíratlan regényei ott olvashatók Mishima Yukio könyveiben. ${ }^{212}$ Miként annak a jelentősége is, hogy ,az Anyagyilkosság esztétikuma és lidércessége nem a Witman-fiúk cselekedetéből, nem a gesztus irracionalizmusából következik, hanem az elbeszélés formaeszméjéböl", ${ }^{213}$ mely formaeszmény - az eddigiek ismeretében - sokban kapcsolódik a meséhez.

Csáth Géza prózáját olvasva a mese eredeti, orális hagyományához kötődő sajátságainak figyelembe vételével válik értelmezhetővé novellisztikájának ,a mesélés

\footnotetext{
${ }^{208}$ AMBRUs Enikő: Csáth Géza és a pszichoanalízis. In: DÉR Zoltán (szerk.): i. m. 148.

${ }^{209}$ DoBos István: Racionalitás és misztikum. In: DÉR Zoltán (szerk.): i. m. 61-62.

${ }^{210}$ Ezzel kapcsolatban lásd Csáth pszichoanalitikus esettanulmányának a nyelvhasználat problematikusságát tematizáló részeit: CsÁTH Géza: Egy elmebeteg nö naplója. Magvető, Bp., 1987.

${ }^{211}$ THOMKA Beáta: A kárhozat grammatikája. In: DÉr Zoltán (szerk.): i. m. 48.

${ }^{212}$ Vö. TOLNAI Ottó: i. m. 174.

${ }^{213}$ THOMKA Beáta: A kárhozat grammatikája. In: DÉR Zoltán (szerk.): i. m. 48.
} 
körülményeit, társadalmi szabályait" és ennek szövegszerü, az irodalmi prózaformákban felbukkanó jegyeit érintő része. ${ }^{214}$ A folyamatos beszédet és mesemondást kísérő állandó jelenlét így válik a seherezádéi állapot: a szöveg általi, szövegbeli létezés megtapasztalásának eszközévé.

${ }^{214}$ Vö. KIBÉDI VARGA Áron: Népmese és irodalomelmélet. = Uö.: i. m.118. 
2. Mese-árnyak az elbeszélés sűrüjében: Szini Gyula novellisztikája

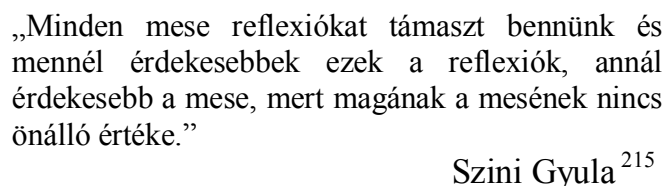

Ez a kissé talán metaforikus fejezetcím egy erdőbe vezet, az irodalmi hagyomány és a fikció rengetegébe, ahol „a fák megannyi szoknyás kísértetek”216 és farkastörvények diktálják, hogy a járt utat járatlanra ne cseréld. ${ }^{217}$ Egy literális barangolás pedig Umberto Eco útmutatása szerint is többesélyes, hiszen: „egy erdőn kétféleképpen lehet keresztülmenni. Az egyik módja az, ha egy vagy több úton próbálkozunk (mondjuk, azért, hogy mihamarabb kijuthassunk az erdőből, vagy hogy megtaláljuk a nagymama házikóját, vagy Hüvelyk Matyiét, vagy Jancsi és Juliskáét); a másik az, ha sétára indulunk, hogy felfedezzük, milyen az erdő, és kiderítsük, miért van az, hogy egyes ösvények járhatóak, mások nem". 218

Az irodalmi- és mesehagyomány útvesztőjében barangolva könnyen rábukkanhat az olvasó a századforduló elbeszélőinek, Csáth Gézának, Szini Gyulának és kortársainak a nyomán egy kevésbé járt útra. Ez a rátalálás, azonban szem előtt tartva, hogy ,a századforduló új magyar irodalma mindent mesének tartott, ami nem volt tradicionális, nem volt anekdotikus”219 leginkább „rátévedésnek” tünik. „Özgidácska sete-suta rátévedt az országútra" ${ }^{220}$ - mely tévedés korántsem eltévelyedés, és nem is csupán az öreg néne karjaiba vezető biztos út megtalálása, sokkal inkább olyan értelmezői tevékenység, mely mint rá-tévedés, a szövegek közötti kapcsolat, interpretatív viszonyulás állapota. ${ }^{221}$

A Mese-árnyak az elbeszélés sürüjében cím közelebbről tehát arra a narratológiai problémakörre utal, amely a mese és elbeszélés viszonyát vizsgálva arra a kérdésre igyekszik választ adni, hogy a 20. században egyre meghatározóbbá váló metaforikus prózamodellről alkotott elképzelések közé (pl. a kései Krúdy Gyula, Kosztolányi Dezső vagy Cholnoky Viktor) hogyan illeszthetők be, többek között Szini Gyula írásainak a mese műfaji, szemléletmódbeli jellemzői, melyek mintegy legitimálják az anekdotikus és

\footnotetext{
${ }^{215}$ SZINI Gyula: Ambrus Zoltán. = UÖ.: Stúdiumok. Bp., 1910. 57.

${ }^{216}$ Vö. KRÚDY Gyula: Az útitárs, első fejezet, Osiris, Bp., 1999. 110.

${ }^{217}$ Vö. Jakob GRIMM - Wilhelm GRIMM: Piroska és a farkas. (Lásd bármely kiadást).

${ }^{218}$ Umberto EcO: Hat séta a fikció erdejében. Európa, Bp., 2002. 41.

${ }^{219}$ ALEXA Károly: Világkép és novellaforma a XIX-XX. század fordulóján. (A mese felkutatása, kifosztása és megsemmisítése.) = Uö.: Eleitől fogva (Tanulmányok, esszék.) Kortárs, Bp., 1996. 78.

${ }^{220}$ FAzEKAS Anna: Öreg nénje özikéje. Móra, Bp., 1978. 3.

${ }^{221}$ Vö. FoGARASI György - MÜLLNER András: Rátévedések. Ictus és JATE Irodalomelmélet Csoport, Szeged, 1998.
} 
szecessziós-szimbolista hagyománytól eltávolodó történetmondást.

Miként arra az újabb irodalomértés rámutat, egyre sürgetőbb igény, hogy a 19. század végének a 20. század elejének teljesítményéről is mérlegelő áttekintés készüljön, vagyis a Németh G. Béla által név nélküli korszaknak titulált századfordulós-századelős irodalomtörténeti időszak nevesítése megtörténjen. Erre vállalkozik többek között a Bednanics Gábor és Eisemann György szerkesztésében megjelent Induló modernség kezdődö avantgárd kötet, föként olyan szövegelemzö és problémafölvető írásokkal, melyek ,azokra az alkotókra és szövegekre összpontosítanak, amelyek vagy nem tartoznak a központi kánonhoz, vagy esetleges gyakori emlegetésük filológiai megalapozás és körültekintő értelmezés híján esett meg”.222

Ezek a megközelítések az olyan „elfeledett” vagy korábban „másodrangúnak” tartott szerzők életművét érintik, mint például Ambrus Zoltán, Lovik Károly, Bródy Sándor, Petelei Isván, Cholnoky László vagy Cholnoky Viktor. ${ }^{223} \mathrm{Az}$ említett alkotókra egyaránt igaz az, amit Orosz Magdolna a névsor utolsó alakja kapcsán több helyütt is megjegyez, hogy „a rövid prózai forma, a novella mestere, aki [a] hagyományos formák továbbvitelével és felbontásával az elbeszélés új útjaira lép”. Ugyanakkor hangsúlyozza a történetmondásnak az elbeszéltségről árulkodó jegyeit, melyek többek között ,a történetek lineáris rendjének felbomlása, [...] az egyes történetek lezáratlanságának vagy lezárhatatlanságának tematizálása, az elbeszélt események kitalált, fiktív voltának reflexiója”, 224

Pozsvai Györgyi írásában például Petelei István Alkonyat címü elbeszélésének interpretációjakor kiindulópont „a mü képi elbeszéléspoétikájának elemzése, metaforikusszimbolikus jelentésszövedékeinek kibogozása”. A szöveg elbeszéléselméleti olvasata során a természet, szubjektum és nyelv közötti viszonyrendszer vizsgálatával többek között arra hívja föl a figyelmet, hogy ,a szimbolikus-metaforikus jelentésképzésủ novellában a sötétség-világosság hatáskontrasztja a szereplők indulati lázgörbéjét követi”. ${ }^{225}$ Másutt

\footnotetext{
${ }^{222}$ Vö. Bednanics Gábor - EISEMANN György: Elöszó. In: Uő. (szerk.): Induló modernség - kezdődö avantgárd. Ráció, Bp., 2006. 7.

${ }^{223}$ Ez persze nem jelenti azt, hogy ne lettek volna korábbi kezdeményezések ezen a területen, vagy az említett szerzők kanonizációját előkészítő kiinduló törekvések, mint például a Lovik Károly prózájának ilyetén jellemzőit vizsgáló Thomka Beáta könyv (A pillanat formái. A rövidtörténet szerkezete és müfaja. Forum, Újvidék, 1986.), Dobos Istvánnak Szini Gyula novellisztikájáról tett korai észrevételei (Alaktan és értelmezéstörténet. (Novellatípusok a századforduló magyar irodalmában.) Csokonai, Debrecen, 1995.), vagy Eisemann Györgynek a Bródy Sándor szövegértelmezései (Végidö és katarzis. Orpheusz Könyvek, Bp., 1991.), illetve Bodnár György Petelei-írása (A „mese” lélekvándorlása. Szépirodalmi, Bp., 1988.).

${ }^{224}$ OROSZ Magdolna: Utazás kultúrák között. In: BEDNANICS Gábor - EISEMANN György (szerk.): Induló modernség - kezdődő avantgárd. Ráció, Bp., 2006. 105. és vö. OROSz Magdolna: „Az elbeszélés fonala”. i. m. 248-249.

${ }^{225}$ PozSVAI Györgyi: Az emlékezés iteratív hangoltság körei. In: BEDNANICS Gábor - EISEMANN György (szerk.): i.m. 19-30.
} 
pedig éppen az anekdotikus hagyományok önironikus felülírását látja abban, ahogyan Petelei az Árva Lotti címü elbeszélésében a tragikomikus-groteszk vonások megjelennek, ezáltal pedig „immanensen önreferens, valamint e vetületében saját hagyományát játékosan kikezdő és felülíró műfajpoétika letéteményese". ${ }^{226}$

Több szempontból a fenti névsorban Petelei István vagy a Cholnoky író-testvérek mellett említhető, ${ }^{227}$ a századforduló elbeszélőinek, „ködlovagjainak” egyikeként számon tartott Szini Gyula is. ${ }^{228}$ Novellái a „,Szecessziós szemléletü”, „lírai hangvételű” széppróza jellegzetes Nyugat-korabeli darabjaiként kanonizálódtak, amelyekben gyakoriak ,a mese műfajából átvett, elsősorban hangulati és hangulatvarázsló elemek". ${ }^{229}$ Ugyanakkor novellisztikájának kevésbé idézett részében akárcsak a Mese „alkonya” című esszében a mese alapvető müfaji és poétikai kérdései is helyet kapnak. A Rózsaszínü hó, A sétapálcaerdő, A smaragd, Az üvegpapucs, a Bien Aimé, a Legenda vagy a Yoru herceg legendája olyan alig említett és értelmezett szövegek, amelyek alapján kitünik: Szini Gyula kisprózájának köre nem szükíthető a nosztalgikus, mesei stilizálású, lírai hajlamú szecessziós elbeszélésekre. $^{230}$

Szini Gyulát, a kortársak közül egyik első méltatója, Kosztolányi Dezső is az „erős és új novellaíróink” közé sorolja 1909-ben, és megjegyzi róla, hogy „novellában is lírát ír”. Ugyanakkor Kosztolányi az szintén, aki korán felismeri a novellista elbeszélői attitűdjének

\footnotetext{
${ }^{226}$ Vö. POZSVAI Györgyi: Az anekdotikus hagyományok önironikus felülírása. In: BEDNANICS Gábor EISEMANN György (szerk.): i.m. 161-188.

${ }^{227}$ Miként azt Thurzó Gábor meg is teszi: „,... ez a bizonytalanság egyik legérdekesebb, legsajátabb vonása Szini Gyulának és a Cholnokyakon kívül csak nála találjuk meg a magyar irodalom huszadik századának első két évtizedében" Vö. THURzó Gábor: Szini Gyula emléke. Nyugat, 1940. 5. szám, http://epa.oszk.hu/ 00000/00022/00652/20942.htm. Másutt pedig Mándi Ildikó Cholnoky Lászlótól egészen Hajnóczy Péterig folytatja a névsort. „....az a hajnali tisztánlátás, amivel Szini mámorélményeit mindenkor figyeli (tegyük hozzá, hogy rajta kívül csak Ady, Cholnoky László, majd nagy-nagy szünet után Hajnóczy Péter képes) az éber-mámor készsége..." Vö. MÁNDI Ildikó: Hangulat-szimbolikus mese (Szini Gyula: A sárga batár). In: MEZEI JózSEF (szerk.): Tanulmányok a XIX. század magyar irodalmából. ELTE BTK, Bp., 1983. 203.

${ }^{228}$ Vö. THURZÓ Gábor (szerk.): Ködlovagok. (Írói arcképek.) (Előszó: Márai Sándor.) Szt. István Társ., Bp., é. n. [1941.] 212.

229 VARGHA Kálmán: A novellista Szini Gyula. ITK, 1963/3. 308. Kötetben kisebb tipográfiai változtatásokkal, és a jegyzetapparátus elhagyásával: VARGHA Kálmán: Álomvilág és szecesszió. (Szini Gyula.) = Uö.: Álom, szecesszió, valóság. (Tanulmányok a huszadik századi magyar prózaírókról.) Magvető, Bp., 1973. 46-74. Illetve lásd még: SzINI Gyula: Rózsaszínü hó. (Vál.: Vargha Kálmán.) Magvető, Bp., 1963. 5-36. Ezért a hivatkozás a továbbiakban az ITK-ban megjelent tanulmányra mutat.

${ }^{230} \mathrm{Az}$, hogy a kortársi vélekedés ezt az irányt jelölte ki az értelmezésekben, magyarázható egyúttal a korabeli kritikai szempontrendszer romantikából örökölt fogalmiságával is. Miként az Petelei István novellisztikájáról szólva épp egy Szini-kritka kapcsán Pozsvai Györgyi megjegyzi: „Szini sem menlevelet keresett a lirai-alanyi hangoltság számára, hanem a narratív origó kívülállásának és/vagy bennefoglaltságának paradoxitására hegyezte ki e kérdést: [...]. Az irodalmi megszólalás szerzői (alanyi) szituáltságának a romantikától örökölt értelmezési keretei között pedig a líraiság, s egyben a lírai elbeszélés fogalma megmerevedett. A vázolt körülmény nem csak a Petelei-novellák olvasásmódját vetette vissza esztétikai téren, hanem a magyar irodalmi gondolkodást éppúgy meghatározta." Vö. PozsVAI Györgyi: Az újra meg újra felfedezett Petelei. Tiszatáj, 2002/8. 99-118., http://www.lib.jgytf.u-szeged.hu/folyoiratok/tiszataj/0208/pozsvai.pdf
} 
ősi, a mítoszok, mesék archaikus korához kapcsolódó jellemzőit. „Ösi naivság van benne. A poéták és gyermekek naivsága, amely mindenen csodálkozik."231 Ezután még három alkalommal írt Szini Gyuláról különböző irodalmi lapokban, folyóiratokban. ${ }^{232} \mathrm{Az}$ egy évvel későbbre datált írásának nyitó mondatában már egyértelműbben fogalmaz Kosztolányi: „Szini Gyula írásaival a mai korba menti a tündérmesét”. ${ }^{233}$ Legközelebb a pályakezdést követő, majd egy évtized távlatából már az addigi Szini-életművet áttekintő, terjedelmes írói portré elkészítésére vállalkozott Kosztolányi Dezső a Nyugatban. Itt figyelmeztet arra a mai napig sem magától értetődő irodalomtörténeti tényre, hogy a lírai stilizálású, mesehangulatokkal átszőtt Szini-elbeszélések nem vonhatók egyértelmüen és megnyugtatóan a szecesszióval jelzett századfordulós stílustörekvések körébe, mint azt például Thurzó Gábor 1940-ben a Szini Gyulának emléket állító írásában a szerző regényeiről és elbeszéléseiről szólva megteszi: „hősei, hősnői tündéri graciózussággal, merev, de csodálatos mosollyal lejtenek a szecesszió pompei-vörösei, ezüstjei között”, majd megjegyzi mindennek az okát is: „Szini Gyula hősei elvesztik illúzióikat, de minél tisztábban látják sorsuk ridegségét, szabályosságát, annál jobban menekülnek az elveszett illúziók közé. Ennek a szüntelen, programos [sic!] szecessziónak bizonyos gépiesség lesz a vége". ${ }^{234}$ Nemkülönben néhány évvel korábban Elek Artúr is a nosztalgikus emlékeket, a lírai finomságú mesélőt dicséri Szini Gyulában, a válogatott elbeszélései mellé írt tanulmányában, bár ő ezúttal inkább a szimbolizmusnak a hétköznapi kötöttségek alól felszabadító szépségvágya felől nevezi meg ezt a törekvést. ${ }^{235}$ „A lírai szimbolizmusnak elragadó példái az ilyen történetei. Olyan mesemondó volt, kinek hallgatása közben az ember észrevétlenül visszamerül rég elhagyott gyermekkorába, melyben az életnél annyival szebbnek és kívánatosabbnak tetszett az álmodás." ${ }^{236}$ Ám már Kosztolányi is arra figyelmeztet Szini Gyula kapcsán, hogy míg „másokról elég azt lejegyeznem; hogy regényesek, vagy hogy a középkori babonák üldözöttjei, hogy naturalisták, vagy szimbolisták. Ö összetettebb jelenség, semhogy általánosítsak". ${ }^{237}$ Elek Artúr is a sokszínűséget dicséri Szini írásművészetében, és erősen elragadtatott zárómondatai mintha csak az akkor már jól ismert Szini-esszé, A mese „, alkonya” igazi müvészének ismérveit

\footnotetext{
${ }^{231}$ KosZTolánYi Dezső: Szini Gyula. = Uö.: Tükörfolyosó. Szerk., és jegyz.: RÉz Pál. Osiris, Bp., 2004. 317.

${ }^{232}$ A Réz Pál által szerkesztett és jegyzetekkel az Osiris kiadónál megjelent Kosztolányi-kötetben a Szini Gyula című négy számozott részben közölt írások eredetileg különböző időpontokban és helyeken jelentek meg végigkísérve Szini Gyula munkásságát. Élet, 1909. január 3.; A Hét, 1910. március 27.; Nyugat, 1917. december; Nyugat, 1922. október 1.

${ }^{233}$ KosztoláNYI Dezsö: Szini Gyula.$=$ Uỏ.: i. m. 317-318.

${ }^{234}$ THURzÓ Gábor: Szini Gyula emléke. i. m.

${ }^{235}$ Komlós Aladár: A szépség vállalása. In: Uő.: (bevez, váll.): A szimbolizmus. Gondolat, Bp., 1965. 49-51.

${ }^{236}$ Elek Artúr: Szini Gyula. In: SzinI Gyula: Különös álmok. Vál. Téglás János. Szépirodalmi, Bp., 1983. 12.

${ }^{237}$ KosztolánYi Dezső: Szini Gyula. $=$ Uö.: i. m. 320. [A kiemelés tőlem. B. S.]
} 
vetítenék magára a szerzőre. „Meséiben gyakran összevegyítette a különféle ízeket [...]. Olyan költő volt, ki az emberiség ősi, bujdosó mesekincsét új változatokkal, új színekkel és hangokkal gazdagította meg." 238

Alexa Károly, az Urbán László válogatta Szini-kötet utószavának szánt írásában, pedig már egyenesen úgy aposztrofálja e szerzőt, mint „,rafináltan naiv történetmondó, a kultúra megszállottja,” és egyértelmüen kijelenti, hogy „a kistörténetek tömegét burjánzó életmű sokkal gazdagabb, rétegzettebb, mint azt a pályatársi impressziók jelzik". 239

A reális, életszerü és az irreális, mesei között feszülő ellentét Szini novelláiban a szimbolista elvágyódás illetve szépségszomj, vagy az álom és képzeletvilág szecessziós területére utalódik, mintegy igazolva, magyarázva a szerző lírai karakterét, mely jellemző, és az erre vonatkozó megállapítások ráadásul ,általában együtt járnak a szerzői személyesség jelenlétének latolgatásával" - miként arra Hites Sándor a Szini Gyulavisszaírás címü tanulmányban helyesen rámutat. ${ }^{240}$ Ugyanakkor Thurzó Gábor is érzékeli és szóvá teszi, hogy a mesei stilizálás és a belső, lelki történéseket középpontba állító tematika nem pusztán a sejtelmes, álomszerü és egyszersmind lírai megszólalást szolgálja. A Trilibi, A bábsütő és $A$ sárga batár címü Szini elbeszélésekről szólva állapítja meg, hogy „a novellák formája idővel mind szükebb lesz, és apró írásai mindig akkor a legsikerültebbek, ha egy parabolát, hasonlatot kerekít ki mesévé."241 Majd éppen a mai irodalmi értelmezés szempontjából is legösszetettebbnek tartott Szini-szöveg, ${ }^{242}$ A sárga batár kapcsán említi az E. T. A. Hoffmann párhuzamot, és hívja föl a figyelmet egyúttal a mesehagyománnyal megjelenő jelképes és szimbolikus történetmondásnak egyik legizgalmasabb vetületére, a disszonancia, határhelyzet feszültségéből adódó poétikai kihívásra: „A parabola, a nagy hasonlat átitatja, feloldja a mesét. Ez a vibrálás, ez a félhomály, az a bizonytalanság egyik legérdekesebb, legsajátabb vonása Szini Gyulának”.

${ }^{238}$ ELEK Artúr: Szini Gyula (1876-1932). In: i. m. 13. Vö. „az elbeszélő múvészet valódi súlya tehát nem azon van, amit mondunk [...], hanem azon, hogy hogyan mondjuk... Épp az, az erősen egyéni szín, illat, hang, ami a müvészből kiárad, téveszti meg a laikust, hogy új mesével áll szemben és megvan lepve a költő mese-invenciójától." SzINI Gyula: A mese ,, alkonya”. Nyugat, 1908/1. 27.

${ }^{239}$ ALEXA Károly: Adyék mellett (Szini Gyula). = Uö.: Quodlibet. Kortárs, Bp., 2004. 333-335.

${ }^{240}$ HITES Sándor: Szini Gyula-visszaírás. In: A kánon peremén (Az irodalmi modernség alakváltozatai a XIX-XX. század fordulójának magyar prózájában). Szerk.: EISEMANN György. ELTE XVIII-XIX. századi magyar irodalomtörténeti tanszék, Bp., 1998. 85.

${ }^{241}$ Habár a Thurzó szöveg is követni látszik a mese többértelmű használatából adódó szakirodalmi bizonytalanságot, és a „kerekít ki mesévé” megfogalmazás is a „történetté” jelentés használatát erösíti mégis érthető mindez a novella formai keretét, a hagyományos elbeszélés müfaji korlátait a mesehagyomány felől, annak beszédmódbeli jellemzőivel kitágító eljárás érzékeléseként. Ezt erősíti a Thurzó Gábor írásának korábbi Sziniről tett kissé esszéisztikus megállapítása is: „A toll, mely sorait rója, mesebeli pálca: csipkerózsika erdejévé varázsolja a világot.” Vö. THURzó Gábor: Szini Gyula emléke. Nyugat, 1940. 5. szám, i. m.

${ }^{242}$ Vö. például Hites Sándor: Szini Gyula-visszaírás. In: i. m. 88-94., és MÁNDI Ildikó: Hangulatszimbolikus mese (Szini Gyula: A sárga batár). In: i. m. 200-211. 
Szini Gyula elbeszéléseiben ez a mesének a megítéléséből, a szó jelentéséből (is) adódó többértelmüsége az egyik oldalról a lirizált megszólalás, a stilizáció és szecessziós jegyeket kiemelő történetmondás. Más szempontból, az elbeszélés jelképes, helyenként metaforikus szövegalakításával járó feszültségéből adódó kettősség vagy bizonytalanság a későbbi Szini-szakirodalomban is megfigyelhető.

Vargha Kálmán is mindenekelőtt a szimbolizmushoz köti Szini írásmüvészetét, ${ }^{243}$ az 1907-es első novelláskötetéröl ${ }^{244}$ megállapítja, hogy „teljesen egyéni, sejtelmes, meseserü hangulat szövi át a kötet elbeszéléseit”, amely a mesék tematikáján (mesebeli vasútállomás, tündérlányok) és kifejezéskészletén keresztül szerinte is elsősorban stilizáló szerepű, és az elbeszélés lirizálódását eredményezi. ${ }^{245}$ Ugyanakkor, hasonlóan Szini korábbi értelmezőihez, azt is érzékeli, hogy a szerző elbeszéléseiben megidézett mesei jellemzők, és $A$ mese „,alkonya” esszében Szini Gyula által is körüljárt mese-fogalom nem pusztán „hangulati és hangulatvárázsló” elem, az elbeszélés stilizálásának eszköze. Ám a valóság és ábránd, az élet és illúzió feszültségével járó, a mese hagyományában és a nyelviségben gyökerező jelképiség és metaforikus történetalakítás jól magyarázhatónak tünt a korstílusok felől, a szimbolizmus fogalmiságot negáló sejtelmességével, és a realitástól elzárkózó művészeteszményével. „A művész igazi hivatását az élet fölébe növő szépségeszmény szolgálatában látja" - állapítja meg Szini Gyuláról Vargha Kálmán, majd hozzáteszi: „a művészet és az élet viszonyáról vallott felfogása természetszerüleg vonzotta a szimbolizmus felé”. ${ }^{246}$ A költői megszólalás, lírai hangvétel és mesei stilizálás így elsősorban problémátlanul egymást magyarázó, elsősorban a témaválasztás és a szóhasználat illetve megfogalmazásmód szintjén mozgó jelenségként a szimbolizmus védjegye alá került, mindennek tágabb kontextusát, a Szini-szövegek elbeszéléstechnikai, prózapoétikai összetevőit nem érintve. ${ }^{247}$ Ám azt is hangsúlyozza a Trilibi és egyéb történetek kapcsán, miszerint „,mesék hangulata hatja át Szini novelláit, de írásai még sem

\footnotetext{
243 „Számára a szimbolizmus elsősorban menekülést jelentett az élet durva valóságából, a szürkeségből, a robotból, a jelképek és mesék tisztultabb harmóniájába". Vö. VARGHA Kálmán: A novellista Szini Gyula. i. m. 310 .

${ }^{244}$ SzINI Gyula: Trilibi és egyéb történetek. Lampel R. Kk. Wodianer F. és Fia R. T., (Magyar Könyvtár 485. füzet), Bp., 1907.

245 „... egyrészt a gyermekkorából, másrészt a történelmi múltból keres olyan témákat, amelyeket a maga stilizáló erejével meseszerü lírává tud átformálni és megragyogtatni.” Vö. VARGHA Kálmán: i. m. 307.

${ }^{246}$ Ua. 308-309.

247 Például: „Jelképeit nem mindig lehet megfejteni, »lefordítani« a fogalmi közlés nyelvére, de ez a homályosság, sejtelmesség éppen a szimbolizmus lényegéből következik. Szimbólumai nem átlátszó allegóriák, hanem az élet, halál, a szerelem misztikumáról szóló példázatok.” vagy „A szimbolista író külön világot akar magának teremteni, amelyben az élet jelenségei csak jelképekben élnek tovább. A kor müvészeinek mohó szépségkultuszában sem nehéz megtalálni az élettől való elfordulásnak, a hétköznapok tagadásának gesztusait.” VARGHA Kálmán: i. m. 309.
} 
nevezhetők mesének olyan értelemben, mint Wilde Oscar modern meséi, vagy Balázs Béla szimbolikus mese-elbeszélései”. ${ }^{248}$

Látszólag tehát teljes a bizonytalanság, és kortársai talán éppen ezért még óvatosabban nyilatkoznak Szininek a századelő, századforduló irodalmi palettáján elfoglalt helyét illetően. Kosztolányi azonban egyenesen a korban egyedülálló jelenségként említi Szini novellisztikáját 1917-ben, ${ }^{249}$ melynek egyik okát ő is az akkor még kibontakozó, az uralkodó korstílusok felől csak részben magyarázható jelképiségben látja, ami a mai irodalomértés felöl nézve éppen a prózával kapcsolatban akkor még nem emlegetett metaforikusság jelenlétéről árulkodik: „Elbeszéléseinek igazi magva jelképes, szimbolikus. Két történet fut egymás fölött, az impresszionista, látszatra igénytelen és jelentéktelen mese fölött egy szimbolikus história." 250 Ez a korstílusokat és müfajokat vegyítő eljárás akárcsak a Bodnár György könyvében münemi határsértéseknek nevezett jelenség nem függetleníthető azonban a kor mesekultuszától, és Szini novellisztikájában a mese müfajának az elbeszélőszerkezetre gyakorolt hatásától sem. Sőt esetleg éppen $A$ „,mese” lélekvándorlásában Bodnár György által hiányolt „magyar elméleti koncepció” ${ }^{251}$ alapjai találhatók meg Szini Gyula elbeszéléseinek önreflexív szólamaiban és elméleti, kritikai munkáiban.

Úgy tünik, Alexa Károly joggal állapítja meg tehát említett írásában, hogy „Szinit meseíróként tartja számon a felületes, jobbára a kortársi vélekedéseket újramondó irodalomtörténet”, majd ő is hozzáteszi „,ironikus meséiben, fátyolos élménybeszámolóiban [...] minden hangot kap, ami korának müvészetét foglalkoztatta”. Szini Gyula valóban meseíró, de nem abban az értelemben, amit hagyományosan, vagy a kortársak szemében mindez jelent. Sokkal inkább olyan „mesélő”, akinek - ahogyan Alexa Károly, érzékelve a mese kifejezés körüli kettősséget és bizonytalanságot, igyekszik megfogalmazni - „tudnia kell arról és valahogy érzékeltetnie is kell azt, hogy a világnak van szerkezete, van valamiféle rendje, hogy a történetek egy nagy életmese darabjai". ${ }^{252}$ Így az említett

\footnotetext{
${ }^{248}$ VARGHA Kálmán: i. m. 307.

${ }^{249}$ Vö. „Novelláiból olyan gyüijteményt tudnék összeválogatni, amely gazdagságában, tartalomban, európai értékben páratlan, a mi irodalmunkban pedig példa nélkül való." KosZTOLÁNYI Dezső: Szini Gyula. = Uö.: i. m. 327 .

${ }^{250}$ Ua. 326.

${ }^{251}$ Vö. „A századforduló magyar modernjeinek kísérletei és elméleti sejtelmei nemcsak a mikszáthi riportot és a naturalista dokumentumot akarták beépíteni az elbeszélésben, hanem a lírát, az álmot, a víziót, az elmélkedést és - később a móriczi drámaiságot is. Az irodalomtörténet közhelye, hogy ezek a műnemi határsértések világirodalmi folyamatok részei voltak, vagy éppen világirodalmi érvényü programok vállalásai. S bár nincs mögöttük egyidejü magyar elméleti koncepció, azokkal a rendszerekkel is gondolati ívet alkotnak, amelyek a prekoncepcióktól ugyancsak mentesíteni akarják az elbeszélés felfogását." Vö. BODNÁr György: A „mese” lélekvándorlása. Szépirodalmi, Bp., 1988. 30-31.

${ }^{252}$ ALEXA Károly: Adyék mellett (Szini Gyula). i. m. 334.
} 
novelláinak mesei jellemzői sem lírai hangoltságukban, ábrándos visszafogottságukban stb. keresendők, nem ezért emelhetők ki markáns és a korban markáns, radikálisan újszerü tematikáik és elbeszélő formáik. Ezek a szövegek a mesét nem pusztán stilizáló vagy egyszerü hangulati elemként érintik, ahol is a „meseszerü feldolgozás” a lirizált megszólalás szolgálatában áll; sokkal inkább olyan megközelítést sejtetnek, mely korát meghaladó módon az irodalmi szöveget tágabb kontextusában, egy literális hagyomány részeként kezeli.

„Keleti drágakövek” vagy „türelemjáték kövei” (egy „elméletpótló esszé” mesefogalma) (A mese ,alkonya”)

Azt, hogy a századelő bódító illatú, egzotikusan termékeny mesekultuszában mi az olyan mese, amely ,,irói teremtés eredménye, amit létrehozója csöndes és szerény iróniával személ", ${ }^{253}$ azt éppen Szini Gyula igyekezett az elsők között tisztázni. ${ }^{254}$ 1908-ban, a Nyugat első számában jelent meg Szini Gyula elméletpótló esszéje A mese „alkonya” címen. ${ }^{255}$ Ennek a „sokat idézett” írásnak e jelzője és $A$ „mese” alkonya címváltozat Bodnár Györgytől származik, aki $A$ „mese” lélekvándorlása címü könyvében következetesen ezt a mesét idézőjelező szóalakot használja. ${ }^{256}$ Mivel magyarázható tehát az idézőjelek áthelyeződése, és egyáltalán érdemes-e mindennek jelentőséget tulajdonítani.

Szini Gyula írásában a mese mindkét (idézőjeles és az idézőjelek nélküli) alakja szerepel, és az eltérő írásképnek az esszé szövegében alapvető megkülönböztető szerepe jut. ${ }^{257}$ „Minden elbeszélésben - írja Szini -, [...] két elem van... Az egyik az, amit elbeszélünk, a másik, hogy hogyan mondjuk el. Ha az egyiket »mesé«-nek nevezzük, a másikat pedig »stílus«-nak, csak elkereszteltük és elvágtuk a két ikret, mely minden sziámi testvérpárnál jobban ragaszkodik egymáshoz. Ha az egyik meghal, vele pusztul a másik is." 258

Habár szerinte e két elemet „nem szabad külön képzelni egymástól”, vannak olyan esetek, amikor a „mese” és a „stílus”, vagyis a történet és elöadásmódjának egysége

\footnotetext{
${ }^{253}$ Ua. 333.

${ }^{254}$ Talán ezt is érzékelve írja róla Kosztolányi Dezső már, hogy „Szini Gyula egyik legelső »modern« írónk” vagy „Szini Gyula volt a mind többet akaró vágyunknak egyik legelső hangoztatója, az új magyar irodalom utásza”. Vö. KoszTolánYi Dezső: Szini Gyula. = Uö.: i. m. 320., 322

${ }^{255}$ SzINI Gyula: A mese ,, alkonya”. Nyugat, 1908/1. 24-28. [A kiemelés tölem. B. S.]

${ }^{256}$ BODNÁR György: i. m. 5-7.

${ }^{257}$ Azzal együtt, hogy definitív egyértelműség, vagy fogalmi tisztázás már csak az írás műfaji jellemzöiből adódóan sem várható el a Szini-esszétől; az talán túlzó megállapítás, hogy a mese „alkonyá”-ban „szinte mindegyik bekezdésben más a 'mese' szó értelme". Vö. TARJÁNYI Eszter: A mese-novella poétikai szerepe a századforduló irodalmában. (Ambrus Zoltán három mesenovellája.) Literatura, 2008/4. 469.

${ }^{258} \mathrm{Az}$ alábbi idézetek mindegyike: SzINI: i. m. 24.
} 
felborul, így a jelentős hangsúlyeltolódás miatt egyikük szerepe kitüntetetté válik. Ennek egyik „legenyhébb” formája, „amikor a [...] gyakorlott elbeszélő valami jelentéktelen, érdektelen, megunt történetet annyi ravaszsággal, megjegyzéssel, füszerrel mond el, hogy egészen elfeledjük vagy legalább is elnézzük neki a vékony, silány »mesét «”. Egy sziámi testvérpár hasonlattal élve, az ilyen és ehhez hasonló „rossz elbeszélések” olyan ikerpárokra emlékeztetnek, akiknél az egyik fél csak a másik elcsökevényesedett kinövése, torzóban maradt párja, s mint ilyen, életképtelen, általa azonban az egész is pusztulásra van ítélve. „Kevés mondanivaló sok szóval, sok mondanivaló kevés, félreérthető szóval” - e jelzők már önmagukban is az említett elemek aránytalanságára utalnak, a szavak mennyisége pedig aligha feleltethető meg azok milyenségével, a „stílussal”. A mese „,alkonyá”-ban a „mese”, vagyis az, „amit elbeszélünk” Szini Gyula esszéjében az elbeszélés tartalmi része, maga a történet, a mondanivaló (fabula), amely elválaszthatatlan az elbeszélés másik elemétől, a „stílustól”, az elbeszélés „hogyan”-jától (szüzsé), egymásra vannak utalva, egyik a másikat feltételezi; egységként funkcionálnak.

Csáth Géza A torzszülöttek címü esszéjében a „csodalényekhez” való vonzódás okát keresve Szini Gyulához hasonlóan a sziámi ikrekről szólva említi a mese jellemzőit, így e filogenetikai fejtegetés akár alkotáslélektani elmélkedésként is olvasható. „Hiszen a fantázia legszabadabb, legféktelenebb játéka, a mese is erre való" - írja Csáth. „Szolgálni, kiszolgálni azt a vágyunkat, hogy a természet adott elemeit úgy kombináljuk, vagyis, hogy a valóságot úgy vágjuk szét és rakjuk össze, hogy abból valami sohase látott, valami meglepő származzék. Ez mulattató, nagyszerü és magasrendű játék, mert abba az illúzióba ringat bennünket, hogy alkottunk, teremtettünk." ${ }^{259}$

Mindez persze nem függetleníthető egy szerző irodalmi szövege esetében sem bizonyos alapvető nyelvi, retorikai összefüggésektől. Az adott elemek kombinációjával létrejövő új és váratlan mint alkotásmód, szövegképző eljárás, legyen az akár mese vagy más narratív forma, egyszersmind a figuratív nyelvhasználat terepe is. Ez az, ami képes „a legfantasztikusabb létezők létrehozására a nyelvben rejlő helyzeti potenciál erejénél fogva". ${ }^{260}$ A metafora ismeretelméletéről szólva, épp ez az, amit Paul de Man a kevert alakzatok kapcsán emel ki „abuse”-ként Locke szövegében. A „helytelen használat”, vagyis (a világos, és egyértelmü nyelvhasználatot lehetővé tevő, mégis) a nyelvi normákat áthágó, azokkal visszaélő figuratív nyelvhasználat, az átvitt értelmű megnyilatkozásnak az

\footnotetext{
${ }^{259}$ CSÁTH Géza: A torzszülöttek. = Uö.: Rejtelmek labirintusában. i. m. 315-318. [A dőlt kiemelések a szerzőtöl, a félkövérek tőlem. B. S.]

${ }^{260}$ Paul DE MAN: A metafora ismeretelmélete. = Uö.: Esztétikai ideológia. Ford.: Katona Gábor. Janus Osiris, Bp., 2000. 17.
} 
az ingoványos területe, ahol ,,a szó képessé válik arra, hogy önmagából és önmaga által hozza létre a természetes megfelelővel nem is rendelkező, jelölt entitást”. ${ }^{261}$

Locke ezeket a kevert módozatoknak nevezett alakzatokat, a katakrézis formáit mint ,,a dolgok valós létével” meg nem egyező, és az empirikus létezőt az átvitt értelmü kifejezések torzító hatásával veszélyeztető kreációkat példájában éppen a „torzszülött” létezőkhöz hasonlítja: agyrém, kentaur. „Aki azt hiszi, hogy a kentaur név valami valóságos lényt jelent, az szavakat kényszerít magára, amelyeket dolgoknak vél” - idézi de Man, Locke-ot. A szavak és dolgok, az idea és empíria, a valós és fiktív összenövésénél meghúzódó vékony felület, sérülékeny hártya, sejtelmes maya-fátyol a figurativitás területe. Azoké a nyelvi alakzatoké, melyek ,,a valóság szövetét a legszeszélyesebb módon képesek szétbontani és újraszőni, természetellenes formákban összekapcsolva férfit a nővel, embert az állattal” - fogalmaz de Man a magyarban köznyelvi metaforáknak minősülő névátvitelekkel kapcsolatban: „Valami borzalmas rejtőzik a katakrézis legártatlanabb formáiban is: amikor asztallábról vagy hegyoldalról (vagy az angol kifejezés erre: face of the mountain) beszélünk, a katakrézis már megszemélyesítésbe csapott át, és szellemek meg szörnyek világa sejlik fel előttünk."262

Csáth furcsának minősített, irreálisba hajló, és ezért a vágyak, álmok és mesék régiójába utalt novellái, a mese hagyományával összefüggésben, arra az archaikus felfogásra épülnek, amelyben a csoda és irrealitás magától értetődőnek számított. $A$ torzszülöttek másik belátása is ez, hogy a fiktív, teremtett világ „valóságának a határait” a realitás jelölte ki. ${ }^{263}$ „Aki először kieszelte, lerajzolta a hétfejü sárkányt, vagy mesélt róla, az csakugyan valami olyasmit produkált, ami addig sohase volt, [...] hogy ezt kitalálhassa, elképzelhesse, ahhoz bizony látnia kellett valami nagy gyíkforma, kígyóforma állatot...” Gondolatmenete is ebbe, az eddig csak sejtetett párhuzam megfogalmazásába fut ki, miszerint a torzszülöttek esetében a természet ,ugyanazt csinálja, mint a mi képzeletünk az ismert, évezredek és milliók óta megszokott formákat úgy állítja össze és úgy kombinálja,

\footnotetext{
261 Uo. Ez persze nem azonosítható a metaforaelméletek azon részével, ahol a trópus egy szó szerinti kategória hibájaként, a hagyományos áthágásaként említődik. ${ }^{262}$ Uo.

${ }^{263} \mathrm{Ez}$ az alapfelismerés persze a Csáth által is jól ismert freudi tanokra vezethető vissza és Jacques Lacan fantázia-fogalma is az ősfantázia freudi fogalmára vezethető vissza. A Sigmund Freud elméletében sem a valóság és fantázia köznapi ellentéte a meghatározó, hiszen a pszichoanalitikus felfogás szerint a fantázia nem a valóság ellentéte, hanem éppenséggel annak alapja, fó támasztéka, amely épp azért lehet annyira hatékony, mert maga is tudattalan. Lacan fantáziafogalmával kapcsolatban lásd: Joan CopJEC: Read My Desire: Lacan Against the Historicists. MIT Press, Cambridge, 1995. 109., 122.
} 
ahogy nem szokta"264 - akár csak az ember a mesék ,gyártásakor” és olvasásukkor is.

Szembetünő, tehát hogy Csáth Géza írásában is hasonló logika érvényesül (két lényegileg különböző elem szétválaszthatatlansága) ugyanazzal a hasonlattal (sziámi ikrek) megfogalmazva, mint a Szini-esszében. Talán, az sem véletlen, hogy a torzszülöttekhez és furcsa ikerpárokhoz való emberi viszonyulást magyarázva Csáth is a megszokott forma és új kombináció jelensége kapcsán érinti a mesét, összefüggésben a valós-fiktív, természetes-fantasztikus szembeállítással.

$\mathrm{Az}$ ismert elemek kombinációjával létrejövő új és váratlan mint nyelvi potenciál, szövegképző eljárás a metaforikusság egyes megközelítéseiben is visszatérő jellemző. ${ }^{265}$ Ricoeur metafora-könyvében Ernst Cassirer A szimbolikus formák filozófiája címü munkájáról szólva a Csáth-esszéhez hasonló módon fogalmaz az esztétikai metafora kapcsán. „Célja az illúziókeltés, méghozzá főként oly módon, hogy a világot új szemszögből mutassa be. Ez a hatás pedig jórészt arra a müködésre épül, amely a szokatlan társítások, illetve a tárgyaknak egy személyes látásmód szerinti összekapcsolása esetében [...] figyelhető meg”" ${ }^{266}$ Bármilyen ,illúziókeltés”-ről legyen is szó, az elbeszélő szövegek kapcsán - nem függetlenül a mesétől - mindennek fordítottja is igaz, melyet maga Ricoeur is hangsúlyoz egy későbbi munkájában. ${ }^{267}$ A torzszülöttek címü Csáth-esszé a megszokott formák új kombinációjaként nevezi meg a képzeletnek azt a játékát, mely (e hasonlatban összekapcsolva) a mese és a csodalények megelevenedéséért felelös. Ricoeur is arra figyelmeztet az elbeszélő szövegekben konstituálódó hagyomány estén, hogy „ha a formát, a müfajt és a típust a paradigma címszó alatt fogjuk össze, megállapíthatjuk, hogy a paradigmák a teremtő képzelet különféle szinteken végzett munkájának szülöttei. Nos, ezek a paradigmák, amelyek maguk is egy korábbi újításból jöttek létre, szabályokat szolgáltatnak a későbbi kísérletezés számára az elbeszélés (narration) mezején."268 Ezt követően (a minimális nyelvtani szabályok, végtelen mennyiségű mondat) tétel nyomán

\footnotetext{
${ }^{264}$ Nem utolsó sorban pedig, ahogyan esetenként az álmok tartalmát is a realitás befolyásolja. Csáth 1914-16os Naplójának tetemes részét álomleírások és analízisük teszik ki, hasonló elképzelés keretében. Ezek egyik legérdekesebb, az álomnak és vágynak az akarat felöli megközelítése, az a kérdésfelvetés, hogy az ember mennyiben befolyásolhatja álmait. CsÁTH Géza: Fej a pohárban. (Naplók és levelek 1914-16). Szerk.: SZAJBÉLY Mihály. Magvetö, Bp., 1997. 180.

${ }^{265}$ Példaként említhető a képek hangjait érintő Nelson Goodman írásnak egyik tömör megfogalmazása: „A metafora, úgy tünik, azzal függ össze, miként taníthatunk egy ódon szót új trükkökre - miként alkalmazhatunk régi címkét egyszerüen csak új módon." Vö. Nelson Goodman: Languages of Art. The Bobbs-Merrill Co., Inc., Indianapolis - New York, 1968, illetve Uő.: Az újraalkotott valóságról és a képek hangjairól. (Ford.: Habermann M. Gusztáv.) In: HoRÁNYI Özséb (szerk.): A sokarcú kép. Válogatott tanulmányok a képek logikájáról. Typotex, Bp., 2003. 84-85.

${ }^{266}$ RICOEUR: i. m. 162.

${ }^{267}$ Vö. Paul RicoeUn: Temps et récit. I. L'intrigue et le récit historique. Seuil, Paris, 1983. 85-109.

${ }^{268}$ Paul RicoeUR: A hármas mimézis. Ford.: Jeney Éva. = Uö.: Válogatott irodalomelméleti tanulmányok. (Szerk.: Szegedy-Maszák Mihály). Osiris, Bp., 1999. 283.
} 
megjegyzi, hogy „az újításokat szabályok vezérlik: a képzelet munkája nem a semmiből születik. Így vagy úgy, kötődik a hagyomány paradigmáihoz. De változó viszonyt tarthat fenn ezekkel a paradigmákkal. A megoldások skálája széles; a szolgai alkalmazás és a szándékolt deviancia két pólus határolja, a »szabályozott deformáció« valamennyi fokozatán át. ${ }^{, 269}$ A proppi tipológia és a modern regény viszonylatában Ricoeur ugyanúgy tartja, hogy „a mese (conte), a mítosz és a hagyományos elbeszélés általában közelebb esik az első pólushoz” [ti. „a szolgai alkalmazás”-hoz], ám a szabállyá váló deviancia, az ütközés-egyezés (concordance-discordance) formális elve a torzszülött, disszonáns szövegeljárások leírása szempontjából is találó.

Érdekes módon, a Szini-esszében is mindkét véglet megtalálható. A nyelvi müveletek és a hagyományokhoz való viszonyulás mint a „szolgai alkalmazás” az idézőjelek között használt „mese” kapcsán vetődik fel, melyet „kicsinyes türelemjáték”nak titulál, és ezek a voltaire-i „fable convenue”, igaz vagy hihető mese fogalmának megfelelően olyan „apáról-fiúra szálló mesealkotó” elemek, amelyek „némely türelemjáték köveire emlékeztetnek". ${ }^{270}$ A szándékolt deviancia pedig, amely teremtő képzelet munkájának és elsősorban nyelvi müveletek eredménye Szininél az idézőjelek nélküli mese, mely mesehagyomány mint mintaadó forrás és ennek későbbi müfaji megoldásai nyomán „újításból jöttek létre” és „szabályokat szolgáltatnak a későbbi kísérletezés

\footnotetext{
${ }^{269}$ Uo.

${ }^{270}$ A fable convenue francia kifejezés közkeltü volt föként társadalomtudományi, etikai, szellemfilozófiai írásokban Walter Johannes Stein filozófus, az antropozófia egyik képviselője például önéletrajzában barátja és pályatársa Rudolf Steiner szavait idézve használja. Rudolf Steiner osztrák filozófus és író, az antropozófia megalkotójának elméletében - melyből ízelítőt Szini Gyula is hallhatott Pesten, vagy olvashatott akkortájt* - a hagyomány és a képzelőerő egymást kiegészítő, szoros kapcsolatban áll, akárcsak a Szini-esszében. „Ami mármost a történelem ábrázolását illeti a tanításban, Rudolf Steiner azt a tanácsot adta, hogy a többnyire hézagosan ránk hagyományozottakat belsőleg, utólag alkossuk meg egzakt és produktív képzelőerővel, és utána addig hagyjuk érlelődni az eredményt, amíg elvárható egy lekerekített ábrázolás kialakulása. [...] Ellenvetésemet - miszerint, ha fantáziáját hívja segítségül az ember, könnyen tévedhet pontatlanságokba - Steiner elutasította. Azt mondta: - De hiszen minden hagyományt figyelembe vesz és képi elképzelését átengedi álmán. [...] Ha így jár el ismételten, azt is megfigyelheti majd, hogy a talán több egymást követő éven át előadott ugyanazon anyag megváltozik. És úgy változik meg, hogy egyre pontosabb lesz. Sokkal pontosabb, mint a Fable convenue, amelyet történetnek neveznek."

Vö. Johannes Zeylmans VAN EMMICHOVEN: Ki volt Ita Wegman.(Ita Wegman és az antropozófia.)(4-8. fejezet) Fordította és az előszót írta Kótai Zita. [A kiemelés tőlem. B. S.] http://www.sztmsz.webzona.hu/Emmichoven-II.pdf (2009. július 16.)

* Rudolf Steiner 1906 és 1908 között több előadást tartott az Osztrák-Magyar Monarchia területén, így Budapesten is. Az antropozófia magyarországi történetének szempontjából különösen fontos, hogy Rudolf Steiner harmadik rózsakeresztes előadássorozatának 1909-ben ismét Budapest a helyszíne [budapesti ciklus]. Magyarul lásd Rudolf STEINER: Budapesti elöadások. (Tizenegy előadás Budapesten 1909. május 31. és június 12. között.) Ford.: Kellner Ágnes. Genius, Bp., 2008. Lásd KorCsog Balázs: A Pünkösdi Kongresszustól a Karácsonyi Gyülésig (1907-1923/24) Az 1907-es év Rudolf Steiner életútján és az antropozófia történetében. Novallis. Szellemtudományi és antopozófiai folyóirat.

http://www.novalis.hu/index.php?option=com_content\&task=view\&id=28\&Itemid=46 (2009. 07. 16.)
} 
számára az elbeszélés (narration) mezején". ${ }^{271}$

Ugyanis Szini Gyula esszéjének címében is szereplő idézőjel nélküli mese jelentése, definíció hiányában a szövegösszefüggés alapján közelíthető meg. Szini többnyire egy visszatekintő, Seherezádé, illetve Boccaccio nevével jelzett irodalmi hagyomány részeként beszél a meséről, mely „,az elbeszélés legősibb, legnaivabb eleme”. Narratológiailag a történet-elbeszélés fogalompárral ${ }^{272}$ összefüggésben ez a mese inkább olyan terminusnak tünik, melyben az elbeszélésre mint narratív szerkezetre jellemző módon „az alapforma deformációjával a diszharmónia válik a müvészi hatás központi elemévé”. ${ }^{273}$ Más megközelítésben „ilyenformán nem a »mese«-ként emlegetett történetszerüség elhárítása, hanem inkább az a meggyőződés olvasható ki e megállapításokból, hogy nem a téma hordozza, hanem a megformáltság mikéntje hozza létre az »ami«-ként felfogott jelentéseket. Vagyis a »mondottság hogyanja« (az elbeszélésmód, a szövegalakítás, a hangoltság) "poétikailag értelmezi a közlés tárgyát «." 274

Úgy tünik tehát, hogy Szini Gyula nem egy lejáratott elcsépelt történet-vázban, vagy tanulságban gondolkodik („mese”), hanem egy olyan beszédmódban, elbeszélőattitüdben, amely az adott korban boccacciói színvonalon, újdonsággal képes a korabeli olvasási igényeket ellátni. Ez pedig a 20. század elején (újra) a kis forma, a novella, amely - ahogy esszéjében fogalmaz - ,a mi korunkban milyen tetőfokra jutott és a tömegek ízlésének nevelésében milyen epochális szerepet vitt”. ${ }^{275}$ Szini Gyula írása szerint: míg a mese egy bizonyos elbeszélő hagyományt, beszédmódot jelent, addig a „mese” ennek csupán egyik eleme, amely épp a beszédmódról alkotott felfogás függvényében, a „stílussal” elválaszthatatlan egységet képezve válhat ennek részévé, vagy éppen „rossz elbeszéléssé”. Ez az elbeszélő-attitűd pedig leginkább az általa, illetve a Nyugat kritikusai által hangoztatott modern művészetfelfogás részeként körvonalazható. ${ }^{276}$ Vagyis, ahogy Hites Sándor Szini-tanulmányában olvasható: „az írás kifejtetlenül tartalmazza az

${ }^{271}$ Paul RICOEUR: $A$ hármas mimézis. $=$ Uö.: i. m. 283.

${ }^{272} \mathrm{Vö.} \mathrm{a} \mathrm{fabula/szüzsé,} \mathrm{historie/discours,} \mathrm{plot/story} \mathrm{terminusokkal.}$

${ }^{273}$ THOMKA Beáta: A pillanat formái, i. m. 76.

${ }^{274}$ Hites Sándor: Szini Gyula-visszaírás. In: i. m. 86. (A belső idézetekben Szini Gyula kifejezései, valamint KULCSÁR SZABÓ Ernő Törvény és szabály között címủ tanulmányának beidézett részei olvashatóak. = Uỏ.: Beszédmód és horizont. Bp., 1996. 69.) [A kiemelés tőlem. B. S.]

${ }^{275}$ SzINI: A mese ,alkonya”, i. m. 25.

${ }^{276}$ Találó ezzel kapcsolatban Szegedy-Maszák Mihálynak Szini gondolatmenetének naprakész, aktuális, a 19-20. század irodalmának legújabb jelenségeit érintő szemléletére tett megállapítása: „Szini Gyula $A$ mese »alkonya« című nevezetes eszmefuttatásában a hivatkozások egytől-egyig idegen szerzőkre, a közelmúlt s a jelen elbeszélőire vonatkoznak s a gondolatmenet Wilde-nak egy Gide által följegyzett példázatával ér véget. Vö. SZEGEDY-MASZÁK Mihály: A Nyugat és a világirodalom. = Uö.: Újraértelmezések: Esszék irodalomról. Krónika Nova, Bp., 2000. 
elgondolást, miszerint »a mondottság hogyanjának« kimeríthetetlensége együtt jár azzal,

\section{hogy bármely narratíva létesülése közegében képezi meg jelentéseit”. ${ }^{277}$}

Szini ezért is határolódik el a „mese” elhanyagolását kifogásoló konzervatívoktól, akik szerinte épp az említett két elem legszélsőségesebb szétválasztásában gondolkodnak: „Ök a »mese« alatt azt értik, amit már Voltaire »fable convenue«-nek nevezett. Azokat az apáról-fiúra szálló mesealkotó elemeket, amelyek némely türelemjáték köveire emlékeztetnek, hogy bizonyos »fejtöréssel« és ügyességgel mindig valami elöre megállapított formává, »mintává« rakhatók össze.”278 Ebben a „lelket ölő, gépies mesterségben”, vagyis az előzetes formai követelményekhez igazodó „szöveggyártásban” nyoma sincs - többek között a „stílussal” kiegészülő - egyedinek; elöre megállapított, vagyis kortól, olvasói szokásoktól független szabályok szerint történik. ${ }^{279}$

Szini gondolatmenete végül logikusan vezet az esszé végkövetkeztetéséhez, miszerint a „mese örök”. Szerinte ugyanis ,a világnak bizonyos [ti. meghatározott milyenségü és mennyiségü] mesekészlete van” ${ }^{\text {,280 }}$, ezek a „,nagyon régi és nagyon értékes mesék” drágakövekként ragyognak, mígnem jön egy müvész, aki a még „egyetlen lehetséges ponton új facetet csiszol, amitől a kő [...] egészen újjá" válik. ${ }^{281}$ Vagyis a hagyomány megújítójaként maga is annak részévé lesz. Mi ez, ha nem Ricoeur által az elbeszélő szövegekben konstituálódó hagyomány kapcsán említett „teremtő képzelet különféle szinteken végzett munkájának" egyik megnyilvánulása? Szini felfogásában tehát nem a mondanivaló „magján” (a „mesén”) van a hangsúly, amely „épp oly korlátolt mint [...] érzékeink képessége”, hanem az egyes érzékelések változatainak megkülönböztetési és megfogalmazási képességén, mely mint a formát, a müfajt és a típust magába foglaló elbeszélői paradigma, folyamatosan változó viszonyban áll a hagyománnyal „a szolgai

\footnotetext{
${ }^{277}$ HITES: i. m. 87.

278 Vagy ugyanez Csáth Géza megfogalmazásában: „Neki [ti. a természetnek] az elemek a motívumai, amelyeket azután másként és másként rak össze; így fantáziál a természet - és ez a mulatozása, rakosgató játéka: az élet." Vö. CsÁTH Géza: A torzszülöttek. = Uö.: Rejtelmek labirintusában, i. m. 316.

${ }^{279}$ Talán nem elhanyagolható, hogy Rudolf Steiner - a Szini által is ismerhetett - elméletében épp a szellemi világ és a földi szellemi élet kapcsolatának vizsgálatakor kerül elő a „fable convenue” kifejezés. „A modern ember a maga kényelmességében azt szeretné, hogy a lehető legfelületesebben tálaljanak mindent gondolkodása elé. Ha a régi időket nem az ún. történelem szerint - amely ma csak fable convenue (megszokott mese) -, hanem az igazságnak megfelelően tanulmányoznák, látnák, hogy ösztönszerű hármas tagozódás volt érvényben, [...].” Vö. Rudolf STEINER: Az emberi társadalom szellemi, jogi és gazdasági élete. (Fordította, előszó: Z. Tóth Csaba) [A kiemelés tőlem. B. S.] http://www.ztothcsaba.hu/tartalom/1_konyvespolc/bennunk_elo_jovo/rs19feb8.pdf (2009. 06. 16.)

${ }^{280}$ Ami persze nem puszta „,mese”-halmaz, vagyis történetek, tanulságok tárháza, hanem magába foglalja azok korábbi megfogalmazását, „stílusát” is, amely a „meséhez” hasonlóan az adott kor elbeszélőhagyományának részeként már jól ismert, SzINI: i. m. 26.

${ }^{281}$ Az alábbi idézetek mindegyike: SzINI: i. m. 27. A „mesealkotó elemek” mechanikus ismételgetése helyére Szini elméletében tehát a hagyományhoz való viszonyulás produktív folyamata kerül, a „müvészi” módon való megjelenítéssel kiegészülve, mely elsősorban beszédmód és nyelvhasználat függvénye.
} 
alkalmazás és a szándékolt deviancia” szélsőséges megnyilvánulásai között. ${ }^{282}$

Az esszét záró „kis parabóla” tanulsága szerint, az egyediség sohasem az ismert történetben („mese”), hanem ez elbeszélés módjának, a „stílusának” az eredetiségében van, amely épp az elmondás által lesz olyanná, ami így egészében sohasem létezett; fantázia szülte vágy, fikció. Ez pedig sohasem azonos az érzéki tapasztalattal, az érzékelt „valósággal”, hanem sokkal inkább az ennek illúzióját keltő fiktív, a müvészi tudat sajátságaival egyesített meséhez köthető.

Walter Benjamin a mesemondóról szólva megkülönbözteti a hétköznapi tapasztalatot, primer valóságot, mellyel szemben ott a „szájról szájra járó tapasztalat”, amelyből a mesemondó merít. Egy, a Szini-esszéhez hasonló válságtünetre (,az elbeszélő művészet a végét járja”) reflektálva jegyzi meg, „hogy az emberek elnémulva jöttek meg a harctérrool”, akárcsak A mese „alkonyá”-t záró történet mesemondó embere, majd a „háborús könyvek tíz évvel későbbi áradata minden volt azután, csak éppen nem, amit szájról szájra járó tapasztalatnak nevezhetünk", vagyis mesének. ${ }^{283}$

Ezért is kerülhetett az esszé címében az alkony szó idézőjelbe, hangsúlyozva ezáltal, hogy ez a hanyatlási folyamat viszonylagos. Az, amit Szininél az idézőjel nélküli mese, az elbeszélő hagyomány müvészi részeként maradandó, legfeljebb az ezek színvonalát megközelíteni igyekvő új elbeszélői törekvéseket - és a novella műfaját, melyben ezek megvalósulni látszanak - fenyegeti veszély, éppen akkor, ha a mese „alkonya” és nem a „mese” alkonya érkezik el. „-- Nem a mese fog meghalni, hanem a novella. »La poesia non muore.« És a mese is örök."284

Ahelyett tehát, hogy Szini „a cselekmény trónfosztásától eljutott a cselekmény újraértelmezéséig: a »mese« halála helyett a »mese« lélekvándorlásáig»; sokkal inkább belátható, hogy a mese halála helyére a „mese” halálát állította. Csakis idézőjelek nélkül igaz, hogy „Szini Gyulában már olyan »mesék« eszménye élt, amelyekben a költészet teremtett világa az élet messzi titkainak foglalata”. ${ }^{285}$ Pontosan ez: a mesék törekvése. ${ }^{286}$

\footnotetext{
${ }^{282}$ Vö. Paul Ricoeur: $A$ hármas mimézis. $=$ Uö.: i. m. 283.

${ }^{283}$ Walter Benjamin: A mesemondó (Gondolatok Nyikolaj Leszkovról). = Uö.: Kommentár és prófécia. Gondolat, Bp., 1969. 95.

${ }^{284}$ SzINI: i. m. 28. Tarjányi Eszter találóan jegyzi meg a Szini-esszé polemizáló jellege kapcsán, hogy: ,a két szembeállított vélemény tehát nem annyira a nemzedéki ellentét, hanem a megújulás elé nézö prózapoétika útkeresését jellemzi. Mindkettő a mese újfajta felfogása előtt nyitja, tisztítja meg az utat, az egyik az elháritás-rájátszás dinamikájával, a másik a fogalomkör kitágításával igyekszik felfrissíteni az elbeszélői tradíciót...." Vö. Tarjányi Eszter: A mesenovella poétikai szerepe a századforduló irodalmában, i. m. 470.

${ }^{285}$ BODNÁR: i. m. 7.

${ }^{286}$ Az, amit Bodnár György $A$ „,mese” alkonyáról ír kizárólag $A$ mese ,,alkonyá”-ra igaz, ez valóban „müfaji koncepciót sejtet olyan korban, amelyben még a diadalmas modern líra sem kapta meg a maga elméleti igazolását, a próza pedig teljesen nélkülözte a müfajtörténeti gondolkodás következtetéseit.” Szini írása ebben a formában valóban „elméletpótló esszé”. Vö. BODNÁR: i. m. 5.
} 
A századforduló irodalmának prózaelméleti megalapozásában joggal tekinthetők elszigetelt jelenségnek Szininek és kortársainak „elméletpótló esszéi”. A kibontakozó új műfaj képviselői részben a műfajtörténeti hagyományok hiányában, részben pedig szépíró voltukból adódóan elsősorban magában a kibontakozó müfajban, a novellában rögzítették e forma elméleti hátterét. Ennek eredményeként az elmélet körvonalazatlanul, elszólások, reflexiók formájában van jelen, amely „elméleti” aspektus azonban ily módon elhanyagolhatónak, esetenként pedig egyenesen zavarónak tünik. A Szini-esszében felvetett problémák, és a mese körüli terminológiai bizonytalanság már önmagában is sejteti a szó használatbeli sokrétüségét, azt, hogy a századforduló elbeszéléseiben sokszor a történet, cselekmény szinonimájaként használták a kifejezést. ${ }^{287}$

A Szini-novellákban jelentkező mesemotívumok feltérképezése helyett a rátévedésekre hagyatkozva a mese mint egyszerü forma, ${ }^{288}$ irodalmi hagyomány és kommunikációs stratégia az elbeszélés-szerkezetbe épülve műfajspecifikumai felől válik meghatározóvá. A tematikus áthallásokon túl egyaránt hangsúlyos ezekben novellákban az irodalmi, kulturális hagyományt értelmező jelleg, valamint a mítoszhoz és meséhez való dialogikus viszonyulás.

Az imaginárius topográfiája: mesei visszfény és metaforikus útvesztők az elbeszélésben (A smaragd, A rózsaszínü hó, A sétapálca-erdó)

A 19-20. század fordulójának elbeszélésirodalmában nem ritkák a mesét vagy más egyszerü formákat (mítosz, legenda, példázat, egyéb bibliai történetek) a történetalakítás középpontjába állító szövegek. A századforduló prózájában tendenciózusnak tekinthető „mesekultusz” egyik megnyilvánulási formájaként megfigyelhető „,a mesei vagy mitikus preformákat beemelő intertextuális bázis", ${ }^{289}$ ugyanakkor gyakran ezekkel párhuzamosan jelentkezik az irodalmi elbeszélés metaforizálódása, amikor is „az elbeszélt történet a nyelvjáték szabadsága által metaforikus elbeszéléssé, illetve »elbeszélt metaforá«-vá alakul”. ${ }^{290}$ Miként arra Orosz Magdolna figyelmeztet „az elbeszélés metaforizálódása a korai modernségben lényegében azt jelenti, hogy az elbeszélö irodalom, az elbeszélés új

\footnotetext{
${ }^{287}$ ALEXA: i. m. 78.

288 Thomka Beáta hívja fel a figyelmet arra az alapvető történeti-poétikai kérdésre, hogy „milyen kapcsolatban áll a prózai szöveg a rövid elbeszélés egyéb egyszerü formáival, s közvetlenebbül, hogy jelöli-e a kötődést vagy nem”. (Ezek: ,a mítosz, a legenda, a mese az orális kultúra formái, melyeket a szerkezet, a szakrális funkció és a kommunikációban betöltött szerep különböztet meg az irodalmi szövegektől. Az utóbbiak bonyolult struktúráival szemben egyszerü formát alkotnak, a szervezettség alacsonyabb fokán állnak.") Vö. THOMKA Beáta: A pillanat formái, i. m. 57. és 58-59.

${ }^{289}$ GYARMATI Krisztina: Esztétizmus és intermedialitás a századforduló prózájában. In: i. m. 61.

${ }^{290}$ Orosz Magdolna: „, Az elbeszélés fonala”, i. m. 244.
} 
formáit keresve, a nyelvben eleve benne rejlő eszközökkel él és új lehetőségeket talál azáltal, hogy a metafora szerkezeti elvként müködik a szöveg különböző szintjein”. ${ }^{291}$ A szövegrész érdekessége, hogy a szerzőnő egyrészt - részben a könyve előző fejezetében tárgyalt nietzschei eredendöen metaforikus nyelv tétel nyomán - a metaforikusságot a „nyelvben eleve benne rejlő eszközök” egyikeként említi, másrészt a metaforát a szöveg több szintjén is müködtethető „,szerkezeti elvként” tárgyalja. ${ }^{292}$ Cholnoky Viktor néhány novelláját vizsgálva a könyv szerzője igyekszik rámutatni, hogy ,a nyelv problematikája, a számvetés a nyelvhasználat metaforicitásával és ennek megszüntethetetlensége a korai modernség néhány szerzőjénél a nyelv figuratív kapacitásának játékos megformálásához vezetett". ${ }^{293}$ Ahogyan arra Orosz Magdolna is utal ,a metaforikus nyelvhasználat Cholnoky Viktor számos elbeszélésében müködik szerkezeti elvként", ${ }^{294}$ ugyanakkor Kulcsár Szabó Ernő tanulmányára hivatkozva belátja, hogy „ez a folyamat a különböző szerzőknél gyakran ellentmondásosan és a hagyományos elbeszéléshez kötődve megy végbe". 295

Ez az ellentmondásság vagy átmeneti állapot az értelmezői hozzáállás függvényében a századvég elbeszélői közül többeket, a szimbolizmus és szecesszió stílusjegyeivel összefüggésben, a lirizálódás jelenségéhez kapcsol, míg más megközelítések a hagyományos szövegalkotási eljárások meghaladása gyanánt, a reflexív, ironikus jelleg felerősödésével, a modernitás felé mutató törekvésként értékelik. A kánonképzés jellegéből adódóan a századforduló elbeszélői esetében többnyire néhány név említésére szorítkozik a kritika, vissza-vissza térő szövegekre hivatkozva. ${ }^{296}$ A tipizáló jellegű, stiláris vagy műfaji besorolás-kísérletekhez ritkán társul tényleges interpretáció, ${ }^{297}$ néhány kezdeményezéstől eltekintve egy-egy szerző esetén a kanonizáció minimális

\footnotetext{
291 Ua. 245.

292 Ua. 226-244.

293 Ua. 248.

${ }^{294}$ Ua. 249. Orosz Magdolna itt Eisemann György és Fazekas Natasa e témát érintő írására hivatkozik. Vö. EISEMANN György: Az individuum elbeszélésének modern alakváltozataihoz. (Cholnoky László regényeiről.) In: Uö. (szerk.): A kánon peremén, i. m. 19-32.; FAZEKAS Natasa: Szimbolika és retorika Cholnoky Viktor novelláiban. In: Ua. 33-46.

295 Orosz Magdolna: „Az elbeszélés fonala”, i. m. 249.

${ }^{296}$ Pl. Bródy Sándor: Rembrant, Szini Gyula: Sárga batár, Cholnoky Viktor: Trivulzió-novellák

297 Jellemző ebből a szempontból Borbély Sándor megjegyzése, aki a szövegszerü olvasatot, a novella értelmezését, annak érzelmi hatása ellen dolgozó eljárásnak titulálja, és használhatatlannak érzi a Szininovellák megközelítésében, épp a másokhoz mért szimbólum-kezelése, a mesei átélhetetlensége, vagy az írói élet realitása és az elbeszélések ábrándossága közti feszültség miatt. (Vö. „Nos, az ilyesfajta elemzéssel talán ennek a törékeny kisprózának épp a kitűnő érzelmi hatását semmisítenénk meg. Olvassuk és irodalmi tudatunk részévé tegyük ezeket a novellákat..." BORBÉLy Sándor: Szemlélödés Szini Gyula világában. = Uö.: Tájékozódás. Irodalmi tanulmányok és kritikák. Magvető, Bp., 1986. 17-18.)
} 
korpuszon és elsődlegesen az elméleti bázison alapszik. ${ }^{298}$ Cholnoky Viktor esetében a Vár ucca tizenhét kiadványa jelentett igazán nagy elörelépést az életmű megítélésében, ${ }^{299}$ és ennek nyomán jó néhány szövegértelmezés is felhívta a figyelmet az életmü fontosságára. ${ }^{300}$ Ezzel párhuzamosan a korábban más elbeszélői törekvések részeként tárgyal szerzők esetén is beszélhetünk az újraolvasást sürgető, a korább műfaji és korstílusokhoz történő besorolás felülvizsgálatát szorgalmazó értelmezésekről. ${ }^{301}$ Ugyanakkor - miként arra Dobos István a századforduló novellatípusait tárgyaló alapvető könyvében felhívta a figyelmet - túllépve irodalomtörténet-írásunk azon közhelyén miszerint a századvég elbeszéléseiben megjelenő álmokban, mesékben a „nyers valóság durva érintésétől irtózó szecessziós író »menekülő attitűdje« nyilvánul meg” egyértelművé válik, hogy „ennél többről és másról is hírt adnak a korforduló szecessziós szemléleti elemeket tartalmazó novellái”, 302

Szini Gyula Mese „,alkonya” című esszéjében valamint novellisztikájának kevésbé kanonikus részében tematizált mese mint eleven irodalmi hagyomány elsődlegesen asszociatív, felidéző funkciója, valamint az értelmezést inspiráló vonása miatt prózapoétikai, metaforaelméleti szempontok bevonásával vizsgálható. Ambrus-írásában Szini Gyula is hasonlóképpen e „katalizátor szerepét” emeli ki a mesének: „... minden szavunk, minden mozdulatunk mélyen és jelentősen van beleírva abba a nagy, titokzatos vonatkozásba, amellyel a mi kis világunk a nagyvilággal szemben áll; egy mese tehát, amely pure et simple mese volna, nem lenne értelmesebb, mint egy crétin dadogása.

\footnotetext{
${ }^{298}$ Rácz I. Péter az Eisemann György által szerkesztett $A$ kánon peremén címủ tanulmánykötetről szólva némi joggal teszi szóvá a tényleges szövegértelmezések hiányát: „A kérdések »élővé tétele« ugyanis nem azt jelenti, hogy a ma korszerünek gondolt irodalomelméleti kérdésirányok némelyikét egyszerüen ráhúzzuk a szövegekre, ahogy néhány tanulmány teszi. Célszerűnek mutatkozott volna elsősorban azokat a mechanizmusokat, folyamatokat felsorakoztatni és analizálni, melyek az elemzett szerzőket és műveiket a jelenleg gondolt irodalomtörténeti pozícióba helyezték vagy kényszerítették." Vö.: RÁcz I. Péter: $A$ kánonok peremén. Iskolakultúra, 2001/2. 107.

${ }^{299}$ Vö. Válogatás Cholnoky Viktor kevésbé ismert irásaiból. (Esszék, tanulmányok Cholnoky Viktorról.) Szerk.: Fenyvesi Ottó, Géczi János, Mátis Lívia. Vár ucca tizenhét, negyedévkönyv, 1993/1. Művészetek Háza,Veszprém, 1993. Illetve lásd BEZECZKY Gábor erről szóló kritikáját: Kötetnyi irás Cholnoky Viktorról. = Uö.: Véres aranykor, hosszú zsákutca. Balassi, Bp., 2005. 166-178.

${ }^{300}$ Lásd Orosz Magdolna „Az elbeszélés fonala” címü könyvének Cholnoky Viktor prózáját tárgyaló részeit, vagy az Induló modernség - kezdödö avantgárd, és A kánon peremén kötetek Cholnoky tanulmányait, illetve BORI Imre témát érintő írásait (pl. A két Cholnoky. = Uö.: Prózatörténeti tanulmányok. Forum - Akadémiai, Újvidék - Bp., 1993. 53-70.

${ }^{301}$ Lásd pl. HANSÁGI Ágnes Eötvös Józsefröl és Jókairól írott tanulmányait (= Uö.: Az Ixión-szindróma. (Identitás és kánon a romantikában és a modernségben.) Ráció, Bp., 2006., vagy pl. HoRvÁTH Kornélia Mikszáth-tanulmányát: Elbeszéloói hang és metaforizációs folyamat. (In: Kiczenko Judit és Thimár Attila (szerk.): A XIX. század vonzásában. (Tanulmányok T. Erdélyi Ilona tiszteletére.) PPKE BTK, Piliscsaba, 2001. 74-95. Továbbá: Kovács Gábor: Figurativitás és prózanyelv. (Mikszáth Kálmán: Bede Anna tartozása.) In: KovÁcs Árpád (szerk.): A regény és a trópusok. (Tanulmányok. A második veszprémi regénykollokvium.) Diszkurzívák, Bp., 2007. 163-178.

${ }^{302}$ Vö. DoBos István: Alaktan és értelmezéstörténet, i. m. 148.
} 
Minden mese reflexiókat támaszt bennünk és mennél érdekesebbek ezek a reflexiók, annál érdekesebb a mese, mert magának a mesének nincs önálló értéke." ${ }^{303}$ Mindez tovább árnyalja $A$ mese ,,alkonyá”-nak fentebb, elsősorban szövegösszefüggései alapján vázolt, idézőjel nélküli mese-fogalmának megértését. ${ }^{304}$

Szini Gyula megítélése a századvég prózairodalmában, a fentiekkel összefüggésben, szintén ambivalens. Míg kortársai elsősorban az „elbeszélő lírikust” méltatták, nagyban a szerző személyiségével, kávéházak teraszán üldögélö, olvasgató, szemüveges figurájával szorosan összekapcsolva írásmüvészetét, addig az utókor és későbbi méltatói néhány szövege nyomán a századforduló és századelő legmeghatározóbb alkotóival egy sorban említik nevét. ${ }^{305}$

Annak ellenére, hogy Szini Gyula úgy került be az irodalomtörténeti köztudatba, mint a „szecessziós-szimbolikus novellák alkotója”306 A mese ,alkonya” mellett a szerző egyik legismertebb és a legtöbbet tárgyalt szövegének, $A$ sárga batár címü elbeszélésnek egyik érdekességét éppen az adja, hogy ugyan a „lirizáló novella” alappéldájaként szerepel az életmüben, mégis poétikai jegyei, szövegszervező eljárásai nyomán a mai befogadói érdeklődésre is számot tarthat. ${ }^{307}$ Különösen figyelemre méltó, hogy a szöveg értelmezői, bár más-más megközelítésből, de egyaránt a szöveg figurativitását, a metaforikus történetvezetés nyomait, a képi láttatás elbeszéléstechnikai megoldásait emelik ki a novella interpretációja során. ${ }^{308}$ Mándi Ildikó is, habár a szecessziós szimbolista és impresszionizmusba gyökerező jegyek felől magyarázza mindezt, mégis utal a „képi

303 SzINI Gyula: Ambrus Zoltán. = Uö.: Stúdiumok. Bp., 1910. 57.

${ }^{304}$ Schultz Adrienn Szini novellisztikájának paradigmaváltó lehetőségeiről szólva, azt hangsúlyozza az esszé kapcsán, hogy „olyan összetett mesefogalommal állunk szemben, mely a művészi megszólalás egészét áthatja, a beszélő helyzet kongurenciájának keresését dokumentálja”. SCHULTZ Adrienn: Paradigmaváltó lehetöségek Szini Gyula novellisztikájában. In: i. m. 52.

${ }^{305}$ A már idézett Kosztolányi méltatás mellett figyelemre méltó Fenyő Miksa megállapítása, amit már Szini Gyula első kötetének megjelenését követően, 1908-ban papírra vet: „A magyar széppróza egyik tartalmas fejezetét kellene megírni. A magyar novelláról szólót. A genetikáját, fejlődését, valamit erről a közhelyről: európai színvonal, aztán három-négy... nem: három mai nevet. Három értéket. S aztán megállapítani, hogy a három legkitünőbb magyar novellista között Szini Gyula is ott van.” FENYŐ Miksa: Szini Gyula: Trilibi és egyéb történetek. Nyugat, 1908/1. http://epa.oszk.hu/00000/00022/00001/00019.htm (2008. 07. 16.)

${ }^{306}$ Vö. pl. http://enciklopedia.fazekas.hu/irodalom/Szecesszio-magyar.htm (2008. 07. 10.)

${ }^{307}$ A Szini-recepció áttekintését követően Hites Sándor is hangsúlyozza az életművel kapcsolatos ,értelmezői bizonytalanságot”, „mely a hagyomány valamely zárványszerü, halott, de rokonszenves »emlékével« történő szembesüléskor lép fel". A Szini Gyula-visszaírásban a szerző egy kettős folyamat következményének látja, hogy Szini „mintegy kiírta magát a kánonból”, ugyanakkor nagyon helyesen úgy véli, ,a század prózatörténeti alakulásának fejleményei felöl beláthatóvá lett poétikai jegyek [...] tudatosításával Szini szövegeinek némelyike termékeny játékba vonható a jelen szövegértési módjaival”. Vö. HiTES: i. m. 86.

${ }^{308}$ Lásd ezzel kapcsolatban pl. Schultz Adrienn megállapítását: „,a metonimikus történetmondás a szöveg több szintjén érintő felszámolását $A$ sárga batár címü novellában követhetjük nyomon”. Vö. SCHULTZ: i. m. 59., Hites Sándor észrevétele szerint „a két alak a novella tropologikus rendjében egymáshoz kötött, ezért a narrátor-szereplő identitása is eredendően bizonytalan. [...] Ennek a szóródásnak metaforikus jeleit nyújtja" a szöveg. Vö. HitEs: i. m. 93. 
láttatás" fontosságára Szini prózájában, $A$ sárga batár címadó nyelvi képét, pedig mint kalandot a nem-léttel, ,a halál állapota, félbemaradt, végig nem vitt, metaforává oldott öngyilkossági kísérlet” módozataként értelmezi. ${ }^{309}$ Felmerül tehát a kérdés, vajon tarthatóe Szini Gyula novellisztikája kapcsán egy olyan megközelítés, melyben nem elsődlegesen a szavak, a mondatok szintjén megvalósuló metaforikusság stilisztikai, beszédmódbeli jellemzői az érdekesek, hanem elsősorban a kompozíció szintjén megvalósuló metaforikus szerkezetek, a metaforikus narráció, a metaforikus történetképzés vagy metaforikus cselekményszerkezet a hangsúlyos? ${ }^{310}$

1 .

Szini Gyula $A$ smaragd címủ elbeszélése ${ }^{311}$ például egy fényűző pesti lakodalom leírásából kiindulva a „magyaros antik ékszerek” kifejezésben jelölt két különböző kultúrkör szembesítésével szervezi a történetet. Ily módon - miként azt Eisemann György egy Poenovella kapcsán pontosan megfogalmazta - előszövegeivel, paratextusaival „,polarizál a szöveg, két kultúra párbeszédét involválja, felvetvén a kulturális szférák szemiotikai szisztémákként való tükröztethetőségét”. ${ }^{312}$ A jellegzetesen magyar öltözékek („díszruhás, mentés párok”; „ez a szín illett harcias jellemü magyar díszruhájukhoz, a kardukhoz, a kacagányhoz”) és az ezeken ragyogó keleti drágaköveknek, „smaragdnak, zafírnak, gyémántnak valóságos zápora" egy felfokozott perceptív szituációban kapcsolódik össze a novellaindító leírást követően. ${ }^{313}$ A csillogás és illat „sajátos keveréke”, mint érzékelési aktus, előkészítője a színkeverés alapfelületét jelentő, „a váratlan meleg és a nehéz menték” miatt pirossá váló arcok, valamint a külső, idegen ,antik ékszerek” keltette visszfény egymásra vetülésének. Ez a percepció itt már nem pusztán a valóság érzékszervek általi közvetlen visszaadását, leképezését szolgálja, sokkal inkább olyan

\footnotetext{
${ }^{309}$ Vö. „Szini egyéni hatás-formáinak fő jellemzője a szimbolizmus és impresszionizmus egymáshoz való viszonya. Mindkettőnek hordozója a képi láttatás, amely egyébként a lírában kap döntő szerepet. A kép szimbolikus, ha az intellektuális feszültséget, ha a jelentést hordozza, és impresszionista, ha a szenzuális szemléletesség uralkodik benne.” MÁNDI Ildikó: Hangulat-szimbolikus mese (Szini Gyula: A sárga batár). In: i. m. 200, 207.

${ }^{310}$ A fogalmakkal kapcsolatban és a téma tudománytörténeti hátteréről lásd. BENYOvsZKY Krisztián: $A z$ elbeszélt metafora. Világosság, 2006/8-9-10. 137-144.

${ }^{311}$ Első megjelenés kötetben SzINI Gyula: A smaragd és egyéb elbeszélések. Athenaeum, Bp., 1919. 3-9. Későbbi kiadásokban: Uö.: Rózsaszínü hó. Vál.: VARGHA Kálmán. Magvető, Bp., 1963. 310-316., Uő.: Különös álmok. Vál.: TÉGLÁS János. Szépirodalmi, Bp., 1983. 299-306. A hivatkozások a továbbiakban az első kiadásra vonatkoznak: Szini Gyula: $A$ smaragd. = Uö.: i. m. és az oldalszám feltüntetésével.

${ }^{312}$ EISEMANN György: A folytatódó romantika. Orpheusz, Bp., 1999. 29.

${ }^{313} \mathrm{Vö.} \mathrm{„A} \mathrm{napon} \mathrm{csillogtak} \mathrm{a} \mathrm{hintók,} \mathrm{lovak} \mathrm{fényes} \mathrm{szőre,} \mathrm{az} \mathrm{ezüstszerszám,} \mathrm{és} \mathrm{a} \mathrm{levegőben} \mathrm{sajátos} \mathrm{keveréke}$ úszott a finom illatnak. A címeres kocsikból díszruhás, mentés párok léptek ki. A váratlan meleg és a nehéz menték pirosra festették az arcukat, és csak ez a szín illet harcias jellemủ magyar díszruhájukhoz, a kardhoz, kacagányhoz.” SzINI Gyula: A smaragd. = Uö.: i. m. 299.
} 
tükröződés, illúziókeltés eredménye, melyben a korlátozott emberi észlelést egyaránt befolyásolja az ábrázolt ékszerekről visszaverődő napfény és az ábrázolás során hasonlóan elvakító narrátori szóhasználat:

„A családi kincstárakból elökerültek a magyaros antik ékszerek. Forgókon, csatokon, pártákon, kösöntyükön a rubintnak, smaragdnak, zafírnak, gyémántnak valóságos zápora ragyogott. A napsugár kigyújtotta tüzüket, és az emberek elkábulva, elvakulva nézték azt a külön világot, amely mintha fellegi saslakokból, ősi várakból szállt volna alá.”314

A két kultúrkör szembesítése, találkozása az elbeszélés során egymásra vetülésük folytán közösen járul „,a külön világ”, a fiktív szövegvilág megteremtéséhez, a hagyományok különbözősége a valóság-illúzió, reális-irreális oppozíciók viszonylagosságát, a narratíva részeként megítélhetőségük relativizálódását hangsúlyozza. Az érzékszervi müködés (,az emberek elkábulva, elvakulva nézték") referenciális, valós idejü tapasztalatait felváltó narrátori szó történetalkotó erejénél fogva, akárcsak a mese, a vágykiélést szolgálja, és az olvasó számára is a „valóságot” fikcióvá alakító, látomással helyettesítő alternatíva (Mennyi kincs, mennyi gazdagság - érezte a nép, és a sóvárgás kiült a szemükbe”). ${ }^{315} \mathrm{~A}$ perceptív képesség és az ezt kísérő észlelés kettéválik, megteremtve ezzel az énelbeszélő és a szereplő-mesélő relatív szólamát, a novella további kettős narrációját. Az történetmondó elbeszélő szerepét és vele hangját ,a kis szürke emberke” kapja, aki viszont „vakságával” meg látszólagos arctalanságával fizet mindezért, ${ }^{316}$ a továbbiakban szinte kizárólag az arcjátéka segítségével, gesztusok útján kommunikáló énelbeszélőnek:

„Egyszer csak a kis szürke emberke, aki mellettem állt, és aki gúnyosan nézte a lakodalmas menetet, fitymálóan szólt:

- Micsoda kolduskompánia! - mondta félig hangosan, és legyintett a kezével.

Elmosolyodtam. A kis öreg belém kötött:

- Talán nem? - kérdezte. - Hiszen a mellényem bal zsebéből ki tudnám fizetni az egész zsibvásárt.

- Uraságod talán a lydiai király vagy a számoszi kényúr? - ilyesmit árulhatott el neki az arcom.

- Sem Kroiszosz, sem Polükratész nem vagyok - szólt a kis ember, iskolásan hangsúlyozva a görög neveket -, de azért lehetnék!..."317

A felidézett mitológiai szereplők mint egy történet emblematikus alakjai, leginkább a narratíva által, meghatározott szövegkörnyezetben identifikálódnak, a névtelen, és arctalan szürke kisöreg kijelentése („Sem Kroiszosz, sem Polükratész nem vagyok [...], de azért

\footnotetext{
${ }^{314}$ SzINI Gyula: A smaragd. $=$ Uö.: i. m. 3. [A kiemelés tőlem. B. S.]

${ }^{315}$ Uo.

${ }^{316}$ Vö. „Csak hónapok múlva pillantottam meg újra alacsony, fürge termetét és nagy homlokú koponyáját, amely valami groteszk antik álarcra emlékeztetett” Ua. 300. [A kiemelés tőlem B. S.]

${ }^{317}$ SzINI Gyula: $A$ smaragd. = Uö.: i. m. 3-4. [A kiemelés tőlem, a félkövér szedés a szereplö-mesélő szavait, a dőlt betüs az énelbeszélő „némaságát” jelölik. B. S.]
} 
lehetnék!...”) úgy is érthető, hogy az említett szereplők által, és történetük részesévé válva határozná meg önmagát; amennyiben a megidézett szöveghagyománnyal érintkező saját elbeszélése ezt lehetővé teszi. A két narratíva egymásra olvashatóságának, illetve a szereplö-mesélő szempontjából egymásba épülésének, folytathatóságának, és ezzel saját létezése megteremtésének az egyik eszköze a smaragd birtoklása. A mítosz- és mesehagyomány jelölőjének, a néhai narratíva emlékét, nyomait hordozó metaforának sajáttá tételére irányul az igyekezete. ${ }^{318}$

A smaragd címü Szini szöveg így más alternatívát jelent a szubjektum narratív létrehozásában, mint például a szerző Tücsökdal címü elbeszélése. Míg ebben „az én megalkotásának formációit az elveszítés momentumához kapcsolják", ${ }^{319}$ addig $A$ smaragdban, a címben is jelölt trópus segítségével a hiány, a néma szólam helye egy, a mitológiai- és mesehagyománnyal dialogizáló történet elbeszélésével töltetik be.

Az énelbeszélő egyetlen saját szólamában „elhangzó” kérdése, melyet verbális, párbeszédes közlés formájában a szerepkörét elfoglalni igyekvő alakhoz, ,a kis öreg”-hez intéz, erre az állapotra (is) reflektál: „Mi az ön foglalkozása tulajdonképp?”. ${ }^{20}$ A megszólalás, a Másik nyelvének birtoklása mint átmeneti, feltételesen előidézhető állapot indokolja a kis öreg álom formájában előrevetülő halálát, a hangra és egy narratíva által arca szert tenni igyekvő lény életképtelenségét. ${ }^{321}$

A látás mint receptív észlelés a fizikai, valós világban eligazodás feltétele, ${ }^{322}$ de a

318 Az ekként értett szó és a szöveg viszonyában a metafora „nemcsak a »feszültség«, »hasonlítás«, »szemantikai összeférhetetlenség« terminusaival írható le [...]." Sokkal inkább ,a metafora a nyelvnek az a költői [ti. irodalmi szövegekben tapasztalható] müködésmódja, amely nemcsak használja, hanem a használó számára egyúttal szemlélhetővé és megragadhatóvá is teszi a szót. A szó így egyszerre alkotja a kifejezés közegét, de a megismerés tárgyát is, a beszélő alany attribútuma és a(z önmagát) megértő alany gondolkodásának instrumentuma is." Vö. SzITÁR Katalin: Szóelmélet és prózaelemzés. In: Szó-elbeszélés - metafora, i. m. 64.

A ,hónapok múlva pillantottam meg újra [...] nagy homlokú koponyáját, amely valami groteszk antik álarcra emlékeztetett” narrátori kijelentésben másodszor szereplö, a „magyaros antik ékszerek” szókapcsolatban előforduló kifejezés, így a smaragd trópuson keresztül egyúttal az ókori, keleti világ és a hozzá kapcsolt történet jelzője is. A szürke kis embernek tehát, nem más, mint ez a kultúrkör ad (ál)arcot, a smaragd és ennek visszfényeként a hozzá kapcsolt történet biztosítja láthatóvá válását, narratív létét.

${ }^{319}$ Hites: i. m. 91.

${ }^{320}$ SzINI Gyula: $A$ smaragd. $=$ Uö.: i. m. 3.

${ }^{321}$ Vö. ,- Életem egyetlen nagy titkát akarom elárulni önnek [...]. - Néhány nappal ezelött különös álmom volt, mely megjósolta közeli halálomat... A haldoklók hiúk... Hallgasson meg." SzINI Gyula: A smaragd. = Uö.: i. m. 6. A szereplö-mesélő antik álarcos így olyan figura, akinek arcvonása retorikai müveletek eredménye, létezése pedig a narratíva fenntarthatóságán múlik. Vö. Paul DE MAN: Az önéletrajz mint arcrongálás. Ford.: Fogarasi György. Pompeji, 1997/2-3. 93-107.

${ }^{322}$ Ebben, a mese- és mitológiai hagyomány értelmezése nyomán szerveződő történetben, fontos lehet a perceptív aktus mint a környezeti ingerek felismerése, jelentéssel való felruházása, ami nem objektív, tapasztalatfüggő; valamint a receptív, nyitott, fogékony, de egyszerü ingerbefogadó attitüd megkülönböztetése. Mindezek hátterében ugyanis a tapasztalásfogalom az változása áll, melyről éppen a meseíró Jacob Grimm tesz említést: „a tapasztalás eredeti jelentésétől a legtávolabb esik a manapság legelterjedtebb jelentés, a dolgok puszta észlelése és felfogása, melyet nem előzött meg semminemű utazás és kutatás". 
befogadó szemében tükröződő smaragd, a narratíva keltett visszfény érzékelése már a percepciót követő fikciós aktus és értelmezői tevékenység eredménye. Az elbeszélni vágyott titok magában a smaragdban, a nyelv metaforicitását és a szöveghagyományt felidéző trópusban van, és mint ilyen birtokolhatatlan és elérhetetlen, de legalábbis kitapinthatatlan. $^{323}$

A szó birtoklása nem azonos a reális tárgy fizikai megragadhatóságával, a történetein keresztül, ${ }^{324}$ azokkal szoros nyelvi szemiotikai kapcsolatban lévő vágy-tárgy egyszersmind nyelv jel, ${ }^{325}$ trópus és mint ilyen az imaginárius jelentéssel összefüggő birtokolhatatlan és megragadhatatlan az érzékszervi észlelés számára:

„A toreutikus fölkelt a helyéröl, szekrényéhez ment, és kivett belőle egy egészen egyszerü szivarosskatulyát. Aztán megfakult selyemrongyok és gyürött papírok tömkelegéből, amibe a drágakő be volt gondosan csomagolva, elővette Polükrátesz smaragdját, és a gyertya reszkető fénye mellett megmutatta. Forgatta minden oldaláról, de a kő nem ragyogott. Csak az ő átszellemült, megittasult szemei előtt. Közönséges kavics volt a kezében...,326

A smaragd trópus, a selyemrongyok és papírok közé csomagolt drágakő szó szerint ettől a „körítéstől”, kontextusától a rongyra és papírra írt történetek, elöszövegek és mese- illetve mitológiai források burkolatában, saját szövegterében az, ami. ${ }^{327}$ Ezek hiányában

Vö. Jacob GRIMM - Wilhelm GRIMM: Deutsches Wörterbuch. München, [Leipzig], 1984. [1862.] 3. kötet, 790. Idézi, kommentálja Reinhard Koselleck: „A szó inkább passzív, receptív jelentése nyomakszik ekkor előtérbe” - majd később hozzáteszi: „Grimmnek igaza volt. Azért szerette volna megmenteni a tapasztalás egykori fogalmának átfogó egységét, mert a valóság receptív megtapasztalása és az átélt valóság produktív felderítése és átvizsgálása kölcsönösen feltételezik egymást, elszakíthatatlanul összetartoznak." Reinhard KoselleCK: Tapasztalatváltozás és módszerváltás. (Történeti-antropológiai vázlat.) Ford.: Hidas Zoltán. = Uö.: Erfahrungswandel und Methodenwechsel. In: Uö.: Zeitschichten. Suhrkamp. Frank-furt am Main, 2000. 27-77. http://epa.oszk.hu/00400/00414/00016/pdf/ 021 koselleck.pdf (2009. 06. 12.)

${ }^{323}$ „Az imaginárus jelentések azok a jelentések, amelyek elötérbe helyezik a figurációt. Ilyen esetekben a jelölő és a jelölt kód vezérelte viszony érvényét veszti, mert az imaginárius jelentések nem tartalmaznak a tárgyi világra való utalást, hanem jelentői mivoltukban voltaképpen olyan utasítások, amelyek elöidézik azt, amit a figuráció tartalmaz." Vö. Wolfgang IsER: A fiktív és az imaginárius. (Az irodalmi antropológia ösvényein.) Ford.: Molnár Gábor Tamás. Osiris, Bp., 2001. 266.

${ }^{324}$ Az előkelő múlt smaragd történetében hivatkozott források, és írásmúvek, a nevek, helyszínek reprodukáló szakértöi eljárása nyomán a szereplő-mesélő a fikcionalitás buktatóira, az értelmezés „,félrevezető” eseteire hivatkozva a nyelvi relativizmustól mentes, egyetlen jelentés, az abszolút igazság önigazoló bizonyításra tesz kísérletet. „Ennek a tudós arabs királynak a drágakövekröl írt munkája nyomtalanul elveszett, de egy régi arads följegyzésében biztos nyoma van annak, hogy övé volt a kö. Juba numídiai király - [...] ismerte ezt a követ, amiről hiteles följegyzéseim vannak. Plinius, aki Juba irataiból merített, az egész történetet, amely a smaragdhoz füződik, rákente egy szardonixkőre..." Vö. SzINI Gyula: A smaragd. = Uö.: i. m. 7-8. [A kiemelés tőlem B. S.]

${ }^{325}$ Azáltal, hogy ,jel-mivoltuk maga lesz a vágyakozásként leírható nyelvi-szemantikai létmód, mely rámutat eredetének - imaginárius teremtőjének - elérhetetlenségére. Vagyis arra, hogy csak e jelölökhöz tapadó szubjektivitás kioltásával válik megérinthetővé a vágyakozás célja...”. Vö. EISEMANN György: i. m. 28.

${ }^{326}$ Vö. SzINI Gyula: A smaragd. = Uö.: i. m. 8-9.

${ }^{327}$ A novellában megidézet mesei, mitológiai szöveghagyomány a smaragd trópuson keresztül leginkább ezek visszfényeként a befogadók tekintetében megcsillanó narratíva. A világban hánykódó „nagyon régi és nagyon értékes mesék", azaz a mesehagyomány metaforáiként ragyogó ,igazi keleti drágakövek” fizikaigeológiai eredetükkel és vizuális optikájukkal a megragadhatóság, nyelvi birtokbavétel iránti vágyakozást képesek felvillantani. Vö. SzINI Gyula: A mese „alkonya”, i. m. 27. 
visszfényét vesztett tárgy, már nem trópus, nyelv jel, csupán valaki vágykivetülése, reprezentáció. A szereplö-mesélő szöveghagyomány és a fikciós narratíva által „átszellemült, megittasult szemei előtt”, más valaminek látni vágyott referencia.

Az eddig a narrációban, a szövegbeli viszonyítottság egymásrautaltságában következetesen toreutikusnak nevezett szereplő-mesélő ezek után „szegény barátom”-ként említődik, mely látszólagos azonosulás a novella végén a történetmondás én-te, én-ö viszonyát feltételező distancia összeolvadását jelenti. Nem véletlen, hogy a smaragd jeltárgy korábbi birtokosa, az aszott hindu, aki „,valósággal egy eleven rothadó és szétfolyó ember”, a szintén koldus csavargó, „Szahib” névvel illeti titkának, és smaragdjának urát, örökösét, az énelbeszélő szegény barátját. A kapott névben rejlő hangsor (sza-hib) egyúttal a félreértett, dokumentatív kézzelfoghatóság átkával bélyegzett drágakő-szakértő karrierjét is jelöli: 'hib-asz'. ${ }^{328}$ Ez a rossz kiejtésü, a pöszeség beszédhibás artikulációját követő hibás(z) felfogás, a félreértettséget, apró fogyatékosságot magában hordó örökség a smaragd megjelenésével és értelmezésével, a disszonancia és határhelyzet fenntarthatatlanságának reprezentációja. A kis öreg, a néhai fuvolásból lett toreutikus leginkább abban téved, hogy újra a valóságot, a puszta referencialitást próbálja az eddigi narratíva segítségével létrehozott imaginárius helyére állítani. Elvakultságában nem érzékelve, hogy végső bizonyítéka, titkának kézzelfogható tárgya, a történetmondás során megképzett figura, az a smaragd, mely a fiktív és imaginárius összjátékának eredménye, az imaginárius médiuma. $^{329}$

Mindez persze nagyrészt a smaragd trópus disszonáns, reális-irreális, valós-fiktív határhelyzetét előidéző megítélésből fakad. A retorika az „igazság” és a hozzá kapcsolódó tárgyi valóság felfüggesztésével a referencialitás helyébe az illúziót, a valódi tárgy helyébe a narratívát helyezi. A magát az egész világot bejáró fuvolásnak valló drágakő-szakértő az elbeszélő szemében csak egy szegény kis öreg, akinek az élete értelmét adó smaragdját a

\footnotetext{
${ }^{328}$ Szitár Katalin tanulmányában Potebnya szóelmélete alapján, Csáth Géza novelláiban vizsgálja a szó és történetképzés viszonyát. Ahol is, az ,olvasó egy-egy sajátos - helytelen, logikátlan, de az is lehet, hogy autonóm, poétikai logikára épülő - nyelvi világgal szembesül”, melyben épp a hangalaki ismétlődések alkotóelemeinek kiemelésével igyekszik bizonyítani, hogy egy szemantikusan telített narrációban ,a szó nem tárgyára vonatkozik, hanem egy másik szóra (vagyis a tárgy jelölőjére).” Az újrajelölésnek ez a Szininovellában is megfigyelhető folyamata nyomán ,a már egyszer valamilyen formában elmondott történet átértelmeződik, a szó mintegy »szétesik«, elemeire bomlik, majd egy másik rendbe illeszkedik, annak érdekében, hogy a leíró történetmondás [...] új jelentésvilágra tegyen szert”. Vö. SzITÁr Katalin: Szó és történetképzés Csáth Géza novelláiban. Schmith mézeskalácsos; Palincsay; Dénes Imre. In: GiNTLI Tibor (szerk.): Változatok a modernitásra. Tanulmányok a Nyugatról. Anonymus, Bp., 2001. 178-191.

${ }^{329}$ Vö. Wolfgang ISER: i. m. 287. „A fiktív - médiumszerepében - a lebontás és a lehetővé tétel egyidejüségeként ereszti szabadjára az imagináriust, ám anélkül, hogy ellenőrzése alatt tarthatná mindazt, ami e kettős ellenpontozás során lezajlik. [...] Amikor a fiktív megkettőző struktúrája kerekedik fölül ezen összjátékban, a jelenlevő háttérbe szorítja a távollévőt, a jelenségek visszája előtérbe nyomakszik, a rámutatás és az ábrázolás poliszémiává tágul, a valótlanság pedig érzékcsalódásként lepleződik le.”
} 
narrátor végül közönséges kavicsnak látja, mégis úgy véli nincs „,nála boldogabb és gazdagabb ember”. Ez a novella-záró tanulság talán mégsem a balgaság dicsérete, és nem pusztán a néphiedelem azon vélekedésének illusztrálása, miszerint a smaragd érintése megkönnyíti a vakság elviselését. Polükratész történetének smaragdja, ${ }^{330}$ a mese- és mitológiai hagyomány metaforájaként megragadhatatlan és birtokolhatatlan, az igazság illúziója csupán. Hisz Nietzsche szavaival „az igazságok illúziók, metaforák, melyek megkopván elveszítették érzéki erejüket, képüket veszített pénzérmék, amelyek immár egyszerü fémek csupán, s nem csengő pénzdarabok". A történet tanulsága, és a narrátor együttérző megjegyzése (,és az én szememből egy forró könnycsepp akaratlanul is szegény barátom keze fejére hullott”) is többszörösen árnyalódik azzal, hogy a nietzschei metaforikusság jelenlétéről tanúskodó passzus, a nyelvhasználat általi relativizált igazság szövegbe emelésével, az egzakt és objektív kijelentés lehetetlenségét fogalmazza meg. ${ }^{331}$

\footnotetext{
${ }^{330}$ SzINI Gyula: A smaragd. $=$ Uö.: i. m. 8. Az első kiadás szövegében Szamosz szigetének türannosza, Polükratész (i.e. 535-522) neve következetesen a 'Polükrátesz' írásmóddal szerepel. A későbbi kiadások közül a Különös álmok. (Vál.: TÉGLÁs János: Szépirodalmi, Bp., 1983.) válogatásban a mai írásmódnak megfelelő Polükratész névalak olvasható. A Rózsaszinü hó kötet (Vál.: VARGHA Kálmán. Magvető, Bp., 1963. 310-316.,) azonban keveri a két írásképet épp a szöveg leghangsúlyosabb részén, „Polükrátesz családi jelvénye” smaragdba vésett azonosításával igyekszik a főhős bizonyítani „hogy a Polükratész gyürüje nem monda, hanem valóság”. Ezáltal a kurzív szedéssel kiemelt mitológiai történet személye és hagyományozott névalakja ebben a kiadásban eleve nem azonosítható a történelmi Polükrátesz család férfitagjával. A szövegkiadási gyakorlaton túl a Szini-novellában mindez a személy és a hozzá köthető, a nevével igazolható történet fikciós kontra dokumentatív narratív dilemmája miatt is érdekes, az olvasatot erősítő ,arany” hiba. [A kiemelések tőlem B. S.]

${ }^{331}$ Vö. Friedrich NIETZSCHE: A nem-morális felfogott igazságról és hazugságról. In: Athenaeum, 1992/3. (Ford.: Tatár Sándor.) 3-15.

Nietzsche 1873-ban írott műve - Orosz Magdolna megállapítása alapján - az 1896-os megjelenését követően a magyar századelő irodalmára is nagy hatást gyakorolhatott. (Vö. Orosz: Az elbeszélés fonala, 226.) Ugyanakkor Györfi Lívia megállapítja, hogy „Noha a nietzschei nyelvfilozófia dokumentumainak az 1873-ban írott $A$ nem-morálisan fölfogott igazságról és hazugságról címü pamfletnek, illetve Az antik retorika vázlata című 1874-es előadásnak - első német kiadása 1903-ra, illetve 1912-re tehető, a korabeli magyarországi Nietzsche-recepciót nem nyelvelméleti kérdések foglalkoztatják." Ezzel kapcsolatban lásd: NIETZSCHE, Friedrich: Über Wahrheit und Lüge im aussermoralischen Sinne (Zusammenhängende Niederschrift). In: Uö.: Nachgelassene Werke aus den Jahren 1872/73 - 1875/76, Leipzig: Neumann 1903 (2. neugestelte Ausgabe), 189-207. (Nietzsche's Werke, X. Band); NIETZSCHE, Friedrich: Rhetorik. In: Uö.: Philologica 2. (Hrsg. CRusIUs, Otto), Leipzig: Kröner 1912, 237-268. (Nietzsche's Werke, XVIII. Band). Vö. GYŐRFI Lívia: A motivált szójelentéstöl a konvencionális megnevezésig. (Kosztolányi Dezső és Friedrich Nietzsche nyelvelméletének analóg vonásai.) http://mek.niif.hu/06500/06547/html/03.htm (2009. 08. 30.) A magyar Nietzsche-recepció alapvető irányultsága leszürhető a magyar Nietzsche-bibliográfia alapján is. (LACZKó Sándor: A magyar nyelvü Nietzsche-irodalom bibliográfiája 1872-1995-ig. http://mek.niif.hu/00600/00622/00622.htm\#f1891 (2009. 08. 30.)

Mindemellett Szini részben német nyelvü Nietzsche-tájékozódást mutatja, hogy az 1922-es Írói arcképek kötet Prosper Mérimée írásához Nietzsche levelezéséből választ mottót a szerző. Vö. SzINI Gyula: Irói arcképek. Világirodalom Kiadás, Bp., é. n. [1922.] 145.

Függetlenül attól, hogy filológiailag bizonyítható-e Szini kapcsolódása Nietzsche $A$ nem-morális felfogott igazságról és hazugságról címü írásának gondolatához - miszerint a helyes, azaz objektív percepciót épp a megismerés nyelvi jelek által történő közvetítettsége, végső soron nyelv eredendő metaforicitása gátolja - A smaragd címü elbeszélés mintha csak a nietzsche-i elképzelést (és részben metaforikát) követné. Abban, ahogyan a novella végén az érzéki erejüket vesztett nem mutatós pénzérmék, vagy drágakövek helyett az egyszerü fém illetve kavics, azaz a közvetítettség nyelvi tapasztalatával járó illuzórikusság megfogalmazása elbizonytalanítja a szöveg csattanójaként szánt igazság, tanulság primátusát.
} 
A szélhámosság tehát nem matrimoniális jellegü, Nietzsche pénzének képe a nyelv metaforicitásának rajzolata, illékony és múló illúzió. Sokkal inkább ebből adódik a reális bizonyíték elmaradása, így a „bizonyítékom van, amit nem lehet megcáfolni” másodlagos elbeszélői kijelentés is inkább érthető arra a narratívára, amivel toreutikai tevékenysége során szembesül, és amitől a szövegben a smaragd létezővé, ha kézzelfoghatóvá nem is, de a fantázia által megragadhatóvá válik. ${ }^{332}$

A Szini-novella végén a papírdarabok és rongyokba csomagolt kavics-smaragd helyére narratív megalkotottsága, a „kelet drágakövek” alakjában felidézet mítosz- és mesekinccsel dialógusba lépő smaragd, A smaragd címü szöveg kerül. Az ily módon megidézett, a novellába bedolgozott mủvelödéstörténeti anyag az illúziókeltést szolgálja, paradox módon valami nem létezőre irányuló várakozás felkeltése, valami másik fizikailag kézelfoghatatlannal, a mesehagyomány és mitológia felidézésével. A nyelvileg adott saját és a betéttörténetekkel felidézett egzotikus, idegen egymásba épülésének eredménye végül maga a szöveg, mely a smaragd történetének felidézésével egyúttal saját, A smaragd címü novella - az iseri fikcióképző eljárások és az imagináció aktusa nyomán kialakuló szerveződését is elbeszéli. ${ }^{333}$

A történetben szereplö drágakö, a smaragd mint a mesehagyomány metaforája narratíva, a „valós smaragdot”, Szini Gyula A smaragd című elbeszélését létrehozó történet, az az epikus emlékezet, ${ }^{334}$ melynek a novellában egyedüli birtokosa nem a narrátor, és nem is a koldus öreg, akiből „bőven áradt a szó”, hanem maga a szerző.

Szini elbeszélő prózájának mai megközelítésében nem hagyhatók figyelmen kívül sem a szövegtér figuratív szerveződésének, sem pedig a trópusok egymáshoz való viszonyának dinamikus, instabil alakulatai. Schultz Adrienn joggal véli úgy, hogy „Szini Gyula novelláinak belső játékteréhez közelebb jutunk, ha megvizsgáljuk a metonimikus és

\footnotetext{
${ }^{332}$ A smaragd drágakő szemantikai többértelműségével nem pusztán az ellenértéket jelentő anyagi javaktól becses, esztétikai hatása nyomán tulajdonosa számára a megfizethetetlen kincs birtoklásának illúziókeltő eszközeként drága; az egyetlen. Jelen értelmezés olvasói perspektívájában nem hagyható figyelmen kívül, hogy Tolkien Gyürük ura című művében Gollam elvakultságát okozó aranygyürű pöszítő megszólításában, drágas(z)ágként becézésében, ott a kincs hordozta hatalom, az illúziókeltés ilyetén eszközének rajongó szeretete is.

${ }^{333}$ A drágakőhöz kapcsolódó hagyományos vélekedés többféleképpen érthető: a smaragd a szem, a látás megjavítója, melynek nézésében a szem nem fárad el soha. Ugyanakkor a smaragdról joggal feltételezik, hogy feltárja a titkokat, segít a hamis barátok felismerésében. Vö. A Pallas Nagylexikon Szini Gyula által is ismerhetett információival. http://www.mek.iif.hu/porta/szint/egyeb/lexikon/pallas/html/012/pc001258.html\#4 (2009. 05. 20.)

334 Walter Benjamin a mesemondás hagyománytörténeti jellemzőit tárgyalva utal a mese és az epikai emlékezet szoros kapcsolatára. Mnemoszüné mint a múzsák anyja, az epika szülöje maga az emlékezés, mely megteremti a hagyományok láncolatát. „Valamennyi mesemondóban él egy-egy Seherezádé, aki a lepergetett mese fonalába mindig új meg új mese szálát ölti. Ez az epikus emlékezet, ez a mese múzsai jellege" Vö. Walter BENJAMIN i. m. 111-112.
} 
a metaforikus történetmondás lehetséges megvalósulását a szövegekben. A kétféle alkotásmód együttes vizsgálata azért fontos, mert Szini Gyula novellái között tisztán metaforikus szövegeket nem találunk.”335

Thomka Beáta korai vizsgálataiban szintén egyértelmüvé tette, hogy a metafora gyakran a prózaszövegek formaszervező elveként a többletjelentések megképzésében, a jelentésbeli ambivalenciák, az asszociációs szemantikai szövegtér létrehozásában müködik közre. Szini Gyula prózája szempontjából nagyonis megfontolandóak a szerzőnőnek az ún. metaforikus szerkezetü regények vagy elbeszélések esetében tett észrevételei (például Krúdy Gyula, Kosztolányi Dezső, Konrád György szövegeiben), a metaforák egymásra épülésének, összefüggésrendszerbe rendeződésének poétikai hozadékai. ${ }^{336}$

Ahogyan például Thurzó Gábor a Trilibi, A bábsütő és $A$ sárga batár címü szövegeket méltatva említett írásában fogalmaz, ez a vibrálás, ez a félhomály, ez a bizonytalanság egyik legérdekesebb, legsajátabb vonása Szini Gyulának és a Cholnokyakon kívül talán csak nála találjuk meg a magyar irodalom huszadik századának első két évtizedében oly gyakori ördöngösök, menekülők, elmerülők Csáth Gézák,

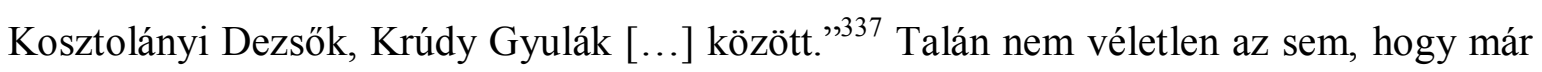
néhány évtized távlatából a Thurzó-írás a Szini Gyulával rokonítható szerzők korábbi listáját (Csáth, Kosztolányi, Cholnoky Viktor és László) Krúdy Gyula nevével egészíti ki. Azzal a Krúdyéval, aki a mai kutatások szerint Kosztolányi Dezső mellett a metaforikus próza egyik első müvelője, ${ }^{338}$ és akinek kései müvei az $N$. N., a Napraforgó vagy a Mit látott Vak Béla szerelemben és bánatban stb., ha nem is egyöntetűen és hangsúlyos módon,

\footnotetext{
${ }^{335}$ SCHULTZ Adrienn: Paradigmaváltó lehetöségek Szini Gyula novellisztikájában. In: MASZÁROviCs Ágnes, MÉsZÁRos Márton (szerk.): Jelenlét '07. (Tanulmányok.) Károli Gáspár Református Egyetem Bölcsészettudományi Kar, Irodalomtudományi Doktori Iskola kiadványi 3., (sorozatszerk.: Hima Gabriella), Bp., 2009. 55-56.

${ }^{336}$ Vö. THOмKA Beáta: Új magyar regényjelenségek. Illetve Uö.: Metaforikus folyamatok a regényben. = Uö.: Narráció és reflexió. Forum. Újvidék, 1980. 22. 39.

${ }^{337}$ THURZÓ Gábor: Szini Gyula emléke. Nyugat, 1940/5. i. m. [A kiemelés tőlem. B. S.]

${ }^{338}$ Szegedy-Maszák Mihály mutat rá egyik tanulmányában arra, hogy a századvég és az un. modern irodalom között döntő különbség figyelhető meg és a 20. századi nagyvárosi tematika, nem feltétlenül jár együtt bizonyos modernek nevezhető poétikai törekvésekkel. „A XX. század második évtizede, a már nem pályakezdő Krúdy $\mathrm{s}$ Kosztolányi elött a regényben hiába keresnénk a metafora $\mathrm{s}$ történetmondás következetes egymásra vonatkoztatását. A Budapest vagy A Pál-utcai fiúk már címével is életképszerüséget ígér, a Napraforgó vagy az Aranysárkány ezzel szemben a másodlagos jelentések világába vezet.” Majd egyenesen megállapítja: „A harmincas évek kiemelkedő magyar regényeinek többsége nem elöre-, de inkább visszalépést jelentett Krúdy s Kosztolányi legjobb múveinek szerkezeti vívmányaihoz képest. Talán még az sem bizonyos, hogy az Iskola a határon poétikája lényegesen különbözik Kosztolányiétól. (Vö. SzEGEDY-MASZÁK Mihály: Konzervativizmus, modernség és népi mozgalom a magyar irodalomban. „Minta a szönyegen”. (A müértelmezés esélyei.) Balassi Kiadó, Bp., 1995. 161.
} 
de a modernitás prózapoétikáját tükrözik. ${ }^{339}$

Az irreális közeget szentesítő, a lineáris, kauzális elbeszélést negáló, a szövegszinten helyenként jelképes megszólalást magyarázó „meseszerüség”, tágabb hagyománytörténeti és textuális kontextusban vizsgálva a jelenséget, akár a Krúdyeffektushoz hasonló poétikai eljárásnak is tekinthető, ahol „a szövegháttér sajátosságáról van szó, amelyet elsősorban a müvek képi világának vizsgálatán keresztül lehet megközelíteni”. 340

Ebben a szövegtérben a Szininél gyakori én-elbeszélői pozíciók sem az önéletrajziság vagy a hétköznapi élettapasztalatok idealizált újramondását szolgálják, ${ }^{341}$ sokkal inkább az emlékezés, felidézés történetképző mozzanatait, a Krúdynál szintén jellemző szövegháttér gyakran képi, figuratív előadását segítik, eközben pedig gyakran a mesemondás és hallgatás kommunikatív szituációjával társulnak.

Talán éppen a mesei stilizáltsággal álcázott erősen szimbolikus már-már metaforikus elbeszéléstechnika az, ami rokonítja egymással e két szerzőt? Dobos István a századforduló novellatípusait vizsgáló könyvében egyértelműen igennel válaszol erre a kérdésre, amikor a metaforikusság szövegszervező eljárásai nyomán említi együtt Krúdy Gyula és Szini Gyula nevét. „A századvég novelláiban már feltűnik a szimbolisztikus elbeszélöszerkezet homológ metaforasora is. A lelkiállapotokat, irracionális sejtelmeket helyzetsorokkal, vizuális észleletekkel, tárgyszimbólumokkal felidéző szabad képzettársításos motívumfejlesztés Krúdy és Kosztolányi epikájában teljesedik ki, de már Lovik, Gozsdu, Szini is tudatosan alkalmazta a századvégen-századelőn."342 Mindemellett

\footnotetext{
${ }^{339}$ Miként arra például Gintli Tibor a Metafora és önazonosság Krúdy Gyula regénytöredékében címủ tanulmányában felhívja a figyelmet: „A szétfutó szövegvilág összefogását - más poétikai jelenségek mellett - a napraforgó figura hivatott megvalósítani. [...]A regényszöveg címbe emelése persze kiemeli e figura jelentőségét, a szöveg és a cím egymásra utalásai mégis viszonylag ritkák, szórványosak, ezért a szöveg nem feltétlenül sugallja az olvasónak, hogy a trópus értelmezése az interpretáció szinte megkerülhetetlen kérdése lenne. (Vö. GINTLI Tibor: Metafora és önazonosság Krúdy Gyula regénytöredékében. Iskolakultúra, 2004/6-7, 97-106.)

${ }^{340}$ Vö. BORI Imre: A Krúdy-effektusok. = Uö.: Prózatörténeti tanulmányok. Forum, Újvidék, 1993. 160.

Azonban miként arra Bori Imre is felhívja a figyelmet a Krúdy-effektusnak nevezett a szövegeljárások az interpretáció során, az olvasó oldaláról jelentenek leginkább kihívást. „Vannak ugyanis Krúdy műveiben szövegrészletek, amelyeket az olvasó rendszerint nem érzékel jelentősebb mértékben, csupán összhatásukban összegeződő benyomásként fogja fel öket. Kimutathatóan azonban ebben az összhatásban nem a regénycselekmény játszik fő szerepet, hanem a szövegháttérnek az anyaga... [...] Következésképpen szerepüket sem a nyelvi megoldások [ti. stilisztikai, beszédmódbeli] szempontjából kell értékelnünk elsősorban. Képi mivoltukban, felbukkanásaikban az egész regény irányultságát, általában az adott müvek tendenciáját alapvető jellegükben reprodukálják."

${ }^{341}$ Lásd ezzel kapcsolatban például Borbély Sándor észrevételét: „Bár viszonylag sok »én-novellát« írt, amikor az elbeszélő maga is szerepel, mégis önéletrajzi elem alig-alig szürödött be a történetekbe, fölösleges is egy-egy motívum valóságos megfeleltetését erőltetni, úgysem az a lényeges ebben a képi világban.” Vö. BORBÉLY SÁNDOR: Szemlélődés Szini Gyula világában. = Uö.: i. m. 18.

${ }^{342}$ DoBos: Alaktan és értelmezéstörténet, i. m. 131.
} 
az Alaktan és értelmezéstörténet Szini novellisztikáját érintő részeiben is érezhető egyfajta bizonytalanság, mely a líraiság és a szimbolizmus stílusjegyei mellett, szinte kizárólag $A$ sárga batár értelmezésére hagyatkozva, mintegy a Szini-elbeszélések ambivalens, nehezen tipizálható karakterét érzékelve igyekszik e szerző irodalomtörténeti helyét valamiféle átmenetiségben, köztes helyzetben kijelölni. ${ }^{343}$

Több szöveg esetében éppen az egyszerü formák elbeszélőszerkezetbe emelése nyomán kialakuló fragmentáltság, a mesebetétekkel megszakított lineáris történet metonimikus előrehaladását a narratív szerkezet metaforikus összetevői törik meg. Még akkor is meghatározó jellemzője lehet ez Szini prózájának, ha elbeszélt történeteinek többségében ,nem felbomlik, hanem módosul az ok-okozati rend logikája”. ${ }^{344}$

2.

Szini Gyula $A$ rózsaszínü hó című elbeszélésében, ${ }^{345}$ akárcsak $A$ smaragdban, egy kitüntetett érzékszervi észlelés állapotában két világ és történet vetítődik egymásra, mely a címadó szókapcsolat nyomán, hasonlóság apropóján köti össze az elbeszélésben felidézett különböző szövegvilágokat. A szimbolikus értelmezést kínáló mese-betét és a látszólag köznapi szerelmi történet egymásba épülése során egyúttal a „rózsaszínben látja a világot” köznyelvi fordulatban jelölt primer látszatboldogság felületi stílusjegyei poétikai feszültségbe kerülnek e hangulat metaforikussá tágított jelével, a rózsaszínủ hó mindent átfestő árnyékával.

A történet egyes szám első személyü elbeszélője egy gyermekkori esemény felidézésével az első mondatában rögtön a szöveg címéhez kapcsolódik, látszólag ezt magyarázza:

„Első találkozásom a rózsaszínű hóval még a gyermekkoromba esik. Szüleim színházban voltak, [...] Csak mi voltunk künn a folyosón: én és Eliz, az elzászi származású bonneunk." ${ }^{346}$

Az indító mondat grammatikai félreérthetősége (a gyermekkoromba/-ra, időhatározó rag

\footnotetext{
${ }^{343}$ Emellett persze elfogadható Dobos Istvánnak az az észrevétele, hogy a lírai önkifejezés szolgáló emlékfelidéző elbeszélőhelyzet számos Szini novellában (Trilibi, A fekete pásztor) valóban elsősorban „a feledésbe merült gyerekkor felködlő emlékképei" nyomán az eltékozolt élet feletti szomorúságnak, az elmúlás melankóliájának megszólaltatója. A szövegalakítás szintjén több más elbeszélése ( $A$ bábsütő, $A$ jegesmedve) sem „teremt öntörvényü szimbólumot, mert megnevezi, hiánytalanul értelmezi, és nem sugalmazza a jelkép tartalmát". DoBos: Alaktan és értelmezéstörténet, i. m. 120.

${ }^{344}$ SCHultz Adrienn: Paradigmaváltó lehetöségek Szini Gyula novellisztikájában. In: i. m. 56.

${ }^{345}$ SzINI Gyula: A rózsaszinü hó. Athenaeum, Bp., 1913. 3-10. Lásd még: Uö.: Rózsaszínü hó. (Vál. és bevez. tan.: Vargha Kálmán.) Magvető, Bp., 1963. 175-180.; illetve Uö.: Különös álmok. (Vál.: Téglás János.) Szépirodalmi, Bp., 1983. 127-233. A hivatkozások az első kiadásra vonatkoznak, a továbbiakban: SzINI Gyula: A rózsaszinü hó. = Uö.: i. m. és az oldalszám feltüntetésével.

${ }^{346}$ SzINI Gyula A rózsaszinü hó. $=$ Uö.: i. m. 3.
} 
helyetti helyhatározó) és a hó konnotációja nyomán aktivizálódó esik ige többértelmüsége miatt (gyermekkoromra tehető vagy gyermekkoromba/ban esik a hó...) az énelbeszélői omnipotencia azonnal megkérdőjeleződik, bizonytalanná válik. A nosztalgikus visszatekintés az emlékezés, felidézés esetlegességével, még inkább pedig a mesemondásés hallgatás narratív aktusával társul. A novella érdekessége, hogy a szerkezetébe fragmentáltan beépülő „szegény ember Nancyban” tanmese, illetve az Eliz egyoldalú szerelmi történetének elbeszélői szólama csak látszólag áll egymással kölcsönös megfeleltetési viszonyban. A két párhuzamosan futó történet metszéspontjában a kamasz fiú nemi identifikációja fontos állomásának tovatűnő pillanata villan fel. ${ }^{347}$ A saját korai élménye, a szexust elörevetítő textus, az énelbeszélő szövegalkotó tevékenysége során, a mese iránti vonzalom formájában igyekszik megragadhatóvá válni. ${ }^{348}$

A napi rutint követő szereplö-mesélő Eliz, az a „rossz mesemondó”, aki visszaél a helyzetével és mint „gyakorlott elbeszélő valami jelentéktelen, érdektelen, megunt történetet annyi ravaszsággal, megjegyzéssel, fúszerrel mond el, hogy egészen elfeledjük vagy legalábbis elnézzük neki a vékony, silány »mesét«". ${ }^{349}$ A fegyelmezési céllal, a saját érdekeit szolgáló szituáció fenntartása miatt mesélő szereplő helyett a ravaszság, illetve füszer ez esetben a felidézett helyzet előadásából és a reprodukált mese összekapcsolásából adódik. A névtelen én-elbeszélő története ettől a füszertől, itt a szó szoros értelmében a füszeresfiú történetbe emelésétől, és az ő elbeszélést beárnyékoló, átszínező figurájától kapja meg „mintaszerü koloritját”. 350

A várakozás előidézte felfokozott percepciójában a folyosón fagyoskodó „pár”, a névtelen énelbeszélö, a tízéves kamasz és Eliz, „a sovány, didergő természetű leány” a történet szerint télvíz idején, a folyosón ácsorogva egymásra utaltságukban fizikailag miként a sziámi ikrek, elválaszthatatlanok. ${ }^{351}$ A szülőket hazaváró kisfiú visszatekintve az

\footnotetext{
${ }^{347}$ Julia Kristeva elméletében a kamaszkor egy olyan képlékeny, nyitott rendszer, amely „a környezettel való viszonya nyomán újítja meg önmagát, a kamasz-képződmény megnyílik az elfojtott dolgok számára, és ebben a pillanatban - a felettes én hatalmának jelentős enyhülése által - elindítja az egyén pszichikai újjászerveződését”. A környezetébe behelyezkedő, új viszonyrendszereket feltételező én pont ez az átmenetiség, változás nyomán identifikálódik. Vö. Julia KRISTEVA: The Adolescent Novel. In: John FLETCHER (ed.): Abjection, Melancholia, and Love: The Work of Julia Kristeva. Routledge, London, 1990. 8.

${ }^{348}$ Lásd ezzel kapcsolatban a pszichoanalízis egyik alapfelismerését, mely a nyelviség jelölőfolyamata és a psziché identifikációs sémája között von párhuzamot. „A szexuális differencia éppoly eredendő, mint a jelentö/jelentett, egzisztencia/esszencia, lét/semmi stb. megkülönböztetése. Nyelv és tudattalan, szexualitás és szubjektum fogalmai nem választhatók szét egymástól. Az énformáció és a nemi »identitás« kialakulása egy és ugyanazon folyamat.” Vö. FARKAS Zsolt: A lacani szubjektumról. Pompeji, 1994/5. 139-166.

${ }^{349}$ SZINI Gyula: A mese ,alkonya”, i. m. 27.

${ }^{350}$ KoszTOLÁNYi: Szini Gyula, i. m. 325.

${ }^{351}$ Vö. „Az egyik az, amit elbeszélünk, a másik, hogy hogyan mondjuk el. Ha az egyiket »mesé«-nek nevezzük, a másikat pedig »stílus«-nak, csak elkereszteltük és elvágtuk a két ikret, amely minden sziámi testvérpárnál jobban ragaszkodik egymáshoz.” SzINI Gyula: A mese „,alkonya”, i. m. 27.
} 
eseményekre, utólag értelmezi ezt a szituációt, melyben az emlékezés, felidézés narratív mozzanatára helyezi a hangsúlyt. A füszeres „nagy, esetlen legény arcára már alig emlékezem, csak rémlik előttem vérmes, piros orcája..." - visszatekintő attitűd szembesül a ,- Fázik a lábam, Eliz - panaszkodtam. Erre az ölébe vett engem, a tízéves kamaszt, és még jobban bebugyolált" típusú, a történet élményszerüségét rekonstruálni hivatott idősíkkal. Ebbe a jelenből a múltba mutató, felidéző szerepű történetbe (,első találkozásom a rózsaszínű hóval még gyermekkoromba esik”) épül bele Eliz meséje, mely a szituációból adódóan folyamatszerüségével, jelenből a jövőbeliségbe mutató temporalitásával (,-- Ha jól viselkedik - ígérte -, mesélni fogok...”) a lineáris, metonimikus elbeszélés célelvűségét és eszményét követi. A befejezésre irányuló énelbeszélői sürgetés ugyanakkor ellentétben áll az Eliz-meséjét meg-megszakító elbeszélői szólam késleltető jellegével. („A szegény ember érezte, hogy sietnie kell. Gyorsan előkereste a mosolygó gyöngyszemet, maga elé tette ágya mellé az asztalkára, és nézte, nézte...[...] Hát aztán mi történt? - faggattam. Eliz szomorúan elmosolyodott: - A szegény ember - szólt - elkezdett mosolyogni.") $)^{352}$ Kettejük egymásra utaltsága narratív természetü, a felidézés során egymásba épülő történetek mesélő illetve elébeszélő szerepre osztása mégis a vágyak, érzések megragadhatatlanságából adódó disszonanciát fokozza. ${ }^{353}$

A kisfiú nevelőnője közelségére, és a mese közvetítette „boldogvégződés” illúziójára, Eliz viszont a szerelmi vonzalma tárgyára, a füszeresfiú „kézzelfoghatóságára” vágyik. Éppen ezt gátolja meg kettejük szoros kapcsolata, az ölében ülő, vele testi érintkezésben lévő néhai kisfiú, a mostani énelbeszélő. A történet rekonstruálása nyomán a múlt idősíkjában még a mesék illúzióiban bízó, ezeket megismerni vágyó kamasz fiú elválaszthatatlan viszonyba kerül a hétköznapi szerelmi vágyat és a realitás praktikusságát követő, követelő nevelőnővel. A történetalakító erre vonatkozó elbeszélői kijelentések (,aa szerelem üzte ki a dermesztő éjszakába”; „szerelmes volt a jómódú füszeresbe.”) éppen ebből a testi viszonyulásból adódó értelmezések, nonverbális jelzések olvasatai, melyekre nézve a cselekmény szintjén, vagy a szereplők párbeszédében semmilyen megerősítés sem található:

\footnotetext{
352 SzINI Gyula A rózsaszínü hó.= UÖ.: i. m. 10.

${ }^{353}$ Ezt erősíti szövegrészeik stiláris különbözősége, széttartó jellege. A rózsaszínü hó című novella több mint egyharmadát kitevő mese-betét stílusában jelentősen elüt a keretéül szolgáló, vele párhuzamosan futó elbeszéléstől. A mesei fordulatok és formulák sematikussága („Egyszer volt - mesélte Eliz - egy szegény ember Nancyban”, ,a lakájok tejben-vajban megfürösztötték, a legszebb ruhát adták rája”), a nyelvi keresetlenség és köznapi szóhasználat esetlegessége („Hallod-e, te szegény ember - szólt az úrnő, én meg akarlak jutalmazni”), az egyszerű poentírozó előadásmód, és a stílusparódiaszerü ironikus megjegyzések (,„»Fogjátok meg ezt a szegény embert, hogy a lába se érje a földet«”, „Két cifra lakáj állt mellette, és hol az egyik, hol a másik törülte le csalánszövésű kendővel úrnője könnyeit”) ellentétben állnak a kerettörténet egységes elbeszélői szólamával.
} 
„Hallatszott, hogy a lépcsőn hogyan jön fel hozzánk a második emeletre a füszeres, Eliznek már nem a mesén járt az esze. Ahogy fázósan a keblére borultam, szinte hallottam a szíve dobogását. A fúszeres felért az emeletre, lépései egyre közelebb értek. Nem vett észre bennünket a sötétben, és fütyörészve ment el mellettünk.

Eliz köhintett, mire a füszeres úgy megijedt, hogy csaknem elvágódott a síkos márványkockán.

- Maga az kisasszony? - kérdezte.

- Én vagyok - felelte Eliz, és forró lett az arca.

A füszeres egy pillanatig habozott.

- No, hát, jó éjszakát, kisasszony - mondta végül. - Ugye nincs egyedül? Szép álmokat.

Köszönt és eltủnt. Ha úgy érezte volna, mint én, az Eliz szíve dobogását, talán maradt volna." ${ }^{354}$

A nevelőnő testi közelségéből adódó kifinomult elbeszélői érzékelés, és az ezzel járó interpretatív késztetés adja a szituáció kézenfekvő leányregényes olvasatát. Ez a látszólag omnipotens, célelvű, az egyoldalú szerelmi történetet szcenírozó előadásmód azonban az emlékezés, felidézés értelmező és újratételező gesztusa jegyében láttatja, valamilyen fényben tünteti föl az eseményeket. A címadó szókapcsolat konnotációja nyomán a „rózsaszínben látja a világot” köznyelvi fordulat, a beépülő mesebetét egyik olvasói javaslataként állítja középpontba az élet szomorúságát, keserüségét megszépítő szemléletet. Az ebben tematizált „két gyöngy” alternatívájának egyikeként választott hozzáállás - a mindent felülíró, visszamenőleg megszépítő boldogságának illuzórikussága - szembesül a kerettörténet Eliz reménytelen szerelmét hangsúlyozó realisztikusságával, köznapiságával. A szövegalakítás szempontjából azonban a készen kapott, tárgyként birtokolható, kézzelfoghatót szembesíti az elbeszélés során megképzett, értelmezői és retorikai műveletek során kitapintható, sejtethető textuálissal. ${ }^{355}$ Eliz arca nem pusztán a szívdobogás kiváltotta vérbőségtől forró és piros, ez a szín egyszersmind a füszeresfiú attribútumaként jelentkezik, a figuráját övező kolorit visszfénye, a „vérmes, piros” orcájú, „rákpiros” kezü vágytárgy jelenlétének árnyéka. („Eliz egy pillanatra abbahagyta a mesét. A pincében elfújták a gyertyát, a füszeres kijött az udvarra, és menés közben árnyéka végigrezgett a rózsaszínű havon.”) ${ }^{356}$

A rózsaszínü hó kifejezés novellaindító említésével az egész történetet beborító és az emlékező, felidéző narratívát meghatározó jelenség mint szókapcsolat oxymoron,

\footnotetext{
${ }_{354}^{354}$ SzINI Gyula: A rózsaszinủ hó. = Uỏ.: i. m. 6. [A kiemelések tőlem. B. S.]

${ }^{355}$ Az elbeszélés és az ebbe beépülő mesebetét, dialogicitása és poétikai feszültsége mellett tematikus szinten a kézzelfogható, valóságos két szélső pont között elhelyezkedő reális tárgy, a „két gyöngyszem” állítódik szembe a „smaragd-nyaklánc” folyamatszerü, körkörös jellegével, mely „az igazi keleti drágakövek”-nek titulált mesehagyományban gyökerezve ennek egyik szereplöjének, a kastély gyerek arcú, hófehér hajú, mégis kortalan úrnöjének jel-tárgyaként földi haladó számára birtokolhatatlan. SzINI Gyula: A rózsaszínü hó. = Uö.: i. m. 5., 8. Illetve vö. SzINI Gyula: A mese „,alkonya”, i. m. 27.

${ }^{356}$ SzINI Gyula: A rózsaszínủ hó. = Uỏ.: i. m. 4-5. [A kiemelés tőlem. B. S.]
} 
fizikailag anomália, vagyis eleve a nyelvi illuzórikusság jelölője. A történet szintjén a „havas márványkockákon a sovány didergő természetű lány”, és a gyertyával a kezében futkosó „göndör hajú segéd” párosításából, vagy még inkább: egymásra vetítéséből adódó látványdarab, szemfényvesztő artisztikum, a fikció árnyjátéka. Szövegelemként a két szereplő összekapcsolásával, az énelbeszélő narratívájában a megfogalmazni vágyott érzések kiváltójaként, a mindezt katalizáló párosításuk eredménye az egyedi, tünékeny, megfoghatatlan; A rózsaszínü hó:

„A sötét, néma udvarra a leghidegebb téli éjszakák vörhenyes ege borult. Haragosvörös ég. Ködén mintha messzi tüzvész fénye verödnék vissza, és az ember ijedt képzeletét csak az nyugtatja meg, hogy fénye egyenletes, mély, skarlátszínü, és benne mintha millió meg millió tüz-atom rezegne. Háztetőre, udvarra, ereszre, párkányokra, kémények gallérjára pedig rásimul mindenütt a rózsaszínü hó préme. Olyan ez, mintha flamingók pihéjéből dunnázták volna fel az udvart sziromtestủ amorettek számára. Van benne valami puha, meleg, csalogató és csalfa jellem, amely merész ellentétben van a csikorgó hideggel. Ekkor láttam először rózsaszínű havat, és nem tudom elfelejteni.",357

A két világ találkozásában, az irreális és reális metszéspontjában, imaginációs zónájában, „az ijedt képzelet” a színkeverés narratív eljárása során vetíti egymásra a két ellentétest, össze nem illőt. ${ }^{358}$ A rózsaszínű hó szokatlan árnyalatát eredményező attribútumokat az elbeszélés során egymáshoz rendelt szereplők hordozzák, az elbeszélői bizonytalanság ellenére a füszeresfiú egyetlen uralkodó tulajdonsága adja a színkeverés vörösét:

„A nagy, esetlen legény arcára már alig emlékszem, csak rémlik előttem vérmes, piros orcája, amely az egészségtől majd hogy ki nem csattant, és nagy, ormótlan keze, amely tele volt repedéssel, sebbel. Rákpiros volt attól a bőrbajtól, amit az angol »grocer's itch«-nek, füszeres-ótvarnak nevez. A szeplős, szepegő elzászi cseléd azt hitte, hogy ha ez a kéz egyszer magához ölelné, abba belehalna." 359

Az etimológiailag a vér, vörös szavak kontaminációjából származó vörhenyes amellett, hogy például a madarak, lepkék elnevezésében és színleírásában szereplő régies színnév, a vörheny nem utolsó sorban a skarlát (scarlatina), heveny fertőző s ragályos betegségre használt népies kifejezés, mely a börön jellegzetes, élénkpiros (vagyis skarlátvörös) kiütés kíséretében jelentkezik. ${ }^{360} \mathrm{E}$ többjelentésű szóalak disszonáns módon egyszerre idézi a füszereslegény egészségtől majd' kicsattanó vérmes, piros orcájának árnyalatát, és

\footnotetext{
${ }^{357}$ Ua. 4. [A kiemelés tölem. B. S.]

${ }^{358}$ Lásd ezzel kapcsolatban a pszichoanalízis egyik alapvető felismerését Farkas Zsolt megfogalmazásában: „A szubjektum »identitása« nem entitás, hanem egy az imaginárius birodalmához tartozó, a folyamatos változással szemben folyamatosan megmerevíteni akart, elidegenült fantomkép. »A beszélő emberi lény« egy lényegileg hasadt, szkizmatikus lény: létét csak mások vágyainak pozíciójából képes érzékelni és megfogalmazni." Vö. FARKAS Zsolt: A lacani szubjektumról. Pompeji, 1994/5. 139-166.

${ }^{359}$ SzINI Gyula: A rózsaszínü hó. = Uö.: i. m. 4. [A kiemelés tőlem. B. S.]

${ }^{360}$ A skarlát mint a szerelmi hevület, a vérmesség arcpírját elfedő tünet a szerelmi szcénát kizárólagosítja $A$ skarlát címü Szini novellában. Vö. SzINI Gyula: A rózsaszinü hó. Athenaeum, Bp., 1913. 185-197.
} 
ormótlan, repedésektől, sebektől piros bőrbajos kezét. ${ }^{361}$ A vörhenyes mint a fehér, szüz felületeket (a hó, havas táj és Eliz, sápadt, „élettelen arca”) abjectként beárnyékoló, ${ }^{362}$ átszínező kolorit vetítődik egymásra a hús- és rózsaszínű hó trópusában. ${ }^{363}$

Ez az elbeszélői eljárás a narrátor nemi identifikációja szempontjából a kivetítés, áttétel módszerével él, melyben saját vágyott, kevésbé verbalizálható érzései szólalnak meg. Az énelbeszélő a férfi-nő, szubjektum-objektum, én-másik, viszonyrendszer részeként az emlékező, felidéző narratíva alakítójaként szerez kitüntetett szerepet az általa (is) formált „imaginárius birodalmá”-ban, A rózsaszínü hó szövegterében. A csupán származásával jelölt (elzászi) lány, akinek neve is a születési helyének betűiből kirakott megjelölés (Eliz), a vágyott Másik viszonylatában, vele relációban ragadható meg. A füszeres fiú uralkodó jellemzőinek metaforája és kifejezéskészlete (piros, vörhenyes) e kölcsönös, egymásrautaltsági viszonyban a lány jellemvonásaiban bukkan fel („A szeplös, szepegő elzászi cseléd azt hitte, hogy ha ez a kéz egyszer magához ölelné, abba belehalna"), ${ }^{364}$ hiszen a vörhenyes egyszersmind a szeplös, vörös hajú külső megnevezésére is használatos a köznyelvben. A Másik vágya mintegy kiül Eliz arcára, a bőrbaj, vagy bőrhiba genetikailag kódolt vörhenyessége a lánynak, ${ }^{365}$ ugyanakkor ennek identifikációs markerré emelése már elbeszélői fogás, mellyel a felcseperedett kamasz nem csupán rekonstruálja, de a verbalizáció során visszafelé haladva újrarendezi és értelmezi nemi identitásának narratíváját. ${ }^{366}$

\footnotetext{
${ }^{361}$ Történetszereplöként „,a nagy, esetlen legény” arcvonásai hiányában az elbeszélés során e tulajdonságával identifikálódó vágy-tárggyá válik, mely ambivalens jellemzője a narratíva központi metaforájának árnyalatát adja. („A sötét, néma udvarra a leghidegebb téli éjszakák vörhenyes ege borult. Haragosvörös ég. [...] fénye egyenletes, mély, skarlátszínú... Háztetöre, udvarra, ereszre, párkányokra, kémények gallérjára pedig rásimul mindenütt a rózsaszínű hó préme.")

${ }^{362}$ Julia Kristeva elméletében az abject, abjectio terminusok a szubjektumnak azt a legarchaikusabb tapasztalatát jelölik, amely a szubjektum kialakuló helyét (amikor nem objektum és nem szubjektum, de már elkülönül), az undor(íto)hoz, a heterogénhez, a kilökendőhöz képest jelöli meg. Az abject elsősorban az a szubjektum számára, ami nehezen jelölhető, és megragadható, vagyis köztes, heterogén, „,cseppfolyós” és így veszélyezteti a szimbolikus fixációt és az azon keresztül kialakulandó identitást. Vö. Julia KRISTEVA: Powers of Horror. An Essay on Abjection. Columbia University Press, 1982. Kristeva megközelítésében az abject a társadalom, a kultúra marginalizált elemeinek, a tisztátalannak szubjektum általi tapasztalata. (Vö. GYIMESI Tímea: Az abject Julia Kristeva szubjektum-felfogásában. Helikon, 1995. 1-2. 140-142.)

${ }^{363} \mathrm{Az}$ azonos című elbeszélésben a rózsaszínủ hó, szövegszervező eszközként, épp a metafora és a cselekmény egymásra hatása szempontjából kap különös jelentőséget, hisz ez esetben „egy metaforikus kifejezés elbeszélt történetté válik.” Vö. Orosz: „,Az elbeszélés fonala”, i. m. 249.

${ }^{364}$ SzINI Gyula: A rózsaszínü hó. = Uö.: i. m. 4. [A kiemelés tőlem. B. S.]

${ }^{365}$ A pszichoanalizis másik felismerése, hogy a vágy mindig valaminek a hiányából táplálkozik, miként a jelölő a jelölt hiányából. Lacan szerint a vágy mindig narratíve formált, nyelvileg meghatározott, a szubjektum is a jelölöfolyamatok része, a nyelv beszéli (el) a szubjektumot. Vö. ERös Ferenc: Jacques Lacan, avagy a vágy tragédiája. Thalassa, 1993/4. 29-44.

${ }^{366}$ A narrativitás fontossága a pszichoanalítikus gyakorlatban felfogható úgy is, mint a „mese mondás”, mondatás egyik formája. Lásd: pl. Jacques LACAN: A beszéd és a nyelvezet funkciója és területe a pszichoanalízisben. Vö. Uö.: Fonction et champ de la parole et du langage en psychanalyse (= Uỏ.: Ecrits. A selection. Tavistock, London, 1977. 237-322.)
} 
A rózsaszínű hó mindezek fényében nem egyszerủen egy köznyelvi fordulat magyarázata, vagy a reménytelen szerelem nagyon is egyértelmü, a novella során megmagyarázott szimbóluma, hanem egy múltbeli esemény elbeszélését újralétesítő narratíva képződménye, a figuráció nyelvi jele, melyhez mindenki másként viszonyul a történetben. A mesemondó-szereplő Eliz, ahelyett, hogy meséje hősével azonosulna, inkább a neki arcot és létet adó énelbeszélővel kerül fizikai és testi kapcsolatba. A tanmese azonban a novella zárómondata szerint mesélöjére nézve látszólag hiteltelennek bizonyult azáltal, hogy a lányban nem tudatosulnak az általa elmondottak és az átélt szituációk összefüggések, e két szerepkör elkülönül, miként a tanmese és tanulsága. A jó és rossz szélső pontjai közötti alternatíva (lásd a mesebetét két gyöngyszeme), a kézzelfogható tanulság helyett azonban inkább a viszonyítottság és a nézőponttól függő relativitás hangsúlyozódik:

„Elizre néztem. Élettelen arca az ajtófélfára ájult, a szeme le volt hunyva, és az ajka halkan remegett. A rózsaszínü hó a háztetőről rávetette gyöngéd fényét. Olyan volt, mint egy halott. Megijedtem tőle, és a vállánál fogva felráztam ájulásából.

- Hát aztán mi történt? - faggattam. Eliz szomorúan elmosolyodott:

- A szegény ember - szólt - elkezdett mosolyogni. Mosolygott, mosolygott, és az arca egyre derüsebb lett. Akik körülötte álltak, azt mondták, hogy mosolyog mindazon, ami vele az életében történt, ami miatt annyit sírt, és amin csak nevetni érdemes.

De Eliz zokogva borult a hajamra." ${ }^{, 367}$

A mesebetétben a két gyöngy használója végül mindent szépnek, rózsaszínủnek lát, és boldogan hal meg. Elizt az énelbeszélö, a betétként előadott mese fényében titulálja halottnak, az arcán ragyogó árnyalat, a mesehagyományt felidéző smaragd színtöréseit is magán viselő rózsaszínű hó hatására. ${ }^{368}$ A szövegben tematizált diszkurzív cselekvések, gyűjtögető, szaporító eljárások egyúttal olyan szövegalkotó altarnatívák, ${ }^{369}$ amelyek az

\footnotetext{
${ }^{367}$ SzINI Gyula: $A$ rózsaszinü hó. $=$ Uö.: i. m. 10.

${ }^{368}$ Az elbeszélés végkifejletében Eliz eszméletvesztéssel járó halálközeli állapota a történet szintjén a rivális nő, ,,a tolvaj”, szerelme vérmességét ellopó hölgy megjelenésével magyarázható, ugyanakkor a vágytárgy viszonylatában korában egyszerủ szófordulatként elhangzó megállapítás („A szeplős, szepegő elzászi cseléd azt hitte, hogy ha ez a kéz egyszer magához ölelné, abba belehalna”) a szövegalakítás során épp az énelbeszélővel való kapcsolatában realizálódik („Elizre néztem. Élettelen arca az ajtófélfára ájult, [...]. A rózsaszínű hó a háztetőről rávetette gyöngéd fényét. Olyan volt, mint egy halott.”). A mesemondó és hallgatója kölcsönös egymásra utaltsága, a befogadó testi közelsége során az egymásba épülő narratívák szorító ölelése vált ki hasonló hatást, a fikciós szövegtér fénytörésében, a fantáziált füszeres árnyékában.

${ }^{369}$ A füszeres-segéd ,éjnek évadján szaporította nagy titokban vízzel a bakui források finomított olaját”; a mesebetét „biffin”-jének hivatása, hogy „,a házak előtt a szemétládából kikotorja azt, aminek ő még hasznát láthatta...”. SzINI Gyula: A rózsaszinü hó. = Uö.: i. m. 4., 5. A novella címválasztása és a szövegben az e szókapcsolat nyomán a metaforikusság visszfényét adó árnyalat szempontjából sem elhanyagolható, hogy az „,igazi keleti drágakövek”-ként ragyogó mesék és a másik kincs „a folyékony arany” valamikori lelőhelye egyaránt Perzsia. „Babilónia hatalmas területein, a mai Baku környékén évezredekkel ezelőtt is lángoló nagy naftaforrások fénye színezte vörösre az eget." Vö. http://mek.niif.hu/00000/00057/ html/06.htm (2009. 07. 10.) A rózsaszínű hó koloritjában e két „forrás”, a füszeres fiú uralkodó tulajdonsága nyomán (vörhenyes) a novellabeli szaporító eljárása során a színkeverés hasonlóságával vetül egymásra.
} 
értelmező szubjektumok és az ezáltal újraértett szereplőviszonyok fényében más-más korpuszt eredményeznek.

A rózsaszínü hó e felidéző, visszatekintő narratív mozzanat során a rózsaszínű hó figurativitásával kibontakozó elbeszélés, amely a történet vége-az élet vége párhuzam bevonásával az Ezeregyéjszaka meséivel jelölt hagyománykörhöz kapcsolódik. Eliz ebben a kontextusban, akárcsak Seherezádé, az életéért mesél, a narratíva fenntartása a befejezés elodázása neki is, mint minden mesélőnek, létfeltétele. Így a Szini-elbeszélés a szövegben létezés egyik eszközeként az emlékezést mint a múlt reprodukciója helyébe lépö, újralétesítés elbeszélő aktusát jelöli meg, nem függetlenül a szubjektum szerveződésének, vágyszerkezetének alakulásrendjétől. ${ }^{370}$

A sárga batárban a képzelet és a valóság egymásra vetítésének eszköze, az alkohol okozta módosult tudatállapot, A rózsaszínü hóban viszont a mese narratív rétege meg a hozzá kapcsolódó vizuális metaforika tölt be hasonló szerepet. A Tücsökdal címü Sziniszöveg viszont a hiány, a másik elérhetetlenségével szembesülve a vágy nyelvét keresve válik metaforikussá, a nyelvhasználat és a szubjektum narrativitása nyomán. ${ }^{371}$

A Kosztolányi-írásban meghúzódó finom megjegyzés, miszerint Szini „észreveszi az élet sok csúnya bütykét és szeplőjét is”, ${ }^{372}$ ez esetben leginkább a szövegtest szépséghibáira értendő. Olyan kettősséggel, narratív feszültségekkel járó disszonancia, mely miként a vonzás és taszítás kettősségéből táplálkozó abjekció, a szubjektum szöveges létmódjának ön- és újraértelmező jellegére utal. A „füszeres-ótvar” egyúttal a szöveg hagyományosan makulátlan hámfelületü, egységes bőrszínű (egységes stílusú és elbeszélőmódok tekintetében egyöntetü) felszínén is pírt hagyott. A kellemetlen betegség mint retorikai müvelet a Ricoeur által „szabállyá váló deviancia”, a de mani „,abuse”, a „helytelen használat”, vagyis „a bevett, »normális« nyelvi müködést áthágó, azokkal visszaélő figuratív nyelvhasználat”, ${ }^{373}$ mely ezúttal a mesehagyomány égető, zavaró,

\footnotetext{
370 Bényei Tamás a pszichoanalízis lacani változatára, és Slavoj Žižek-féle kreatív újraolvasására támaszkodva vállalkozik Szerb Antal „alulkanonizált” regényének értelmezésére, mindenek előtt a fantázia jelentőségét vizsgálva a regényvilág és az elbeszélő szerkezet kialakításában. Jacques Lacan fantáziafogalma nyomán rámutat, hogy a szöveg kontextusába helyezve a fantázia már nem a vágy és elfojtás harcával jellemzi az irodalmat, hanem ennél jóval bonyolultabb, rétegzettebb pszichés reprezentációt mutat meg. BÉNYEI Tamás: Ulpius in fabula: fantázia az Utas és holdvilágban. http://magyartanarok.freeweb.hu /BenyeiT_Utas_es_holdvilag.html (2009.06.11.)

${ }^{371}$ Lásd ezzel kapcsolatban Hites Sándor észrevételeit. Hites: i. m. 91-92.

${ }^{372}$ KosztolánYI: Szini Gyula, i. m. 323.

${ }^{373}$ Vö. Paul DE MAN: A metafora ismeretelmélete. $=$ Uö.: i. m. 17.

A metafora ismeretelméletéről szólva a Lock-szövegben Paul de Man által kevert alakzatoknak nevezett „abuse”, korántsem áll távol az abject kristevai fogalmától, mely a törvényt (a szimbolikust) áthágó tilosként, a mocsok és szenny abnormális tartományában a „helytelen használat” szélsőséges formája gyalázkodás, mocskolódás, megbecstelenítő visszaélés, becsmérlő túlkapás.
} 
mindent felsértő jelenlétéről tanúskodik, a novellába épülve ily módon a rózsaszínü hó visszfénye fertőző árnyékként terjed tovább.

A rózsaszínü hó címü elbeszéléskötet több novellája a mesét, esetenként a mítoszt vagy legendát mint narratív preformát, a homogén elbeszélőszerkezetet a fragmentáltság, a disszonatív nyelvi alakzatok viszonylatában poétikai eszközként kezeli. ${ }^{374}$ A sétapálcaerdő címü Szini-elbeszélésben, majd A rózsaszínü hó című kötet több szövegében (BienAimé, Az üvegpapucs, Csipkerózsika, Legenda), illetve néhány későbbi novellában ( $A$ smaragd, Yoru herceg legendája, Genovéva barlangja, Csendélet) „,a mese a történet, a narratíva szintjén" az elbeszélőszerkezet szempontjából kap kitüntetett szerepet, viszont kevésbé hangsúlyosan ,alakít ki egy olyan fantasztikus világot, amelyben az álomszerü és a látomásos élmény megjeleníthetővé válik". ${ }^{375}$ Közöttük jó néhány szöveg (Bien-Aimé, Az üvegpapucs, Csipkerózsika) ilyen szempontból valóban antimesének is tartható, akárcsak Csáth Mesék, amelyek rosszul végzödnek címen összefoglalt írásai vagy az olyan meseparafrázisok, mint Ambrus Zoltán szövegei, a Hamupipőke vagy a Jancsi és Juliska, mely utóbbi, - akárcsak a többi említett ,antimese” - „a mesemondás és a gyermekkor felnőttessé válásával, mégis megmutatja a meseszerüségnek az elbeszélést meghatározó tendenciáját". 376

3.

$A$ bábsütö, és $A$ jegesmedve mellett $A$ sétapálca-erdö címü Szini-elbeszélésról szólva Dobos István megjegyzi, hogy „nem teremt öntörvényü szimbólumot, mert megnevezi,

\footnotetext{
${ }^{374}$ Szini Gyula szövegei A Trilibi és egyéb történetek címü elbeszéléskötetét (1907) követően, A mese „,alkonya” megjelenésének idején, annak poétikai felismerései, és hozadékait kamatoztatva az 1908-as Lelki kalandok néhány novellájában - köztük a mai érdeklődést fenntartó, a Szini kisprózáját részben kanonizáló $A$ sárga batárban - már ,a valóságábrázolás problematikája helyett a kifejezőkészlet kérdése, az új poétikai eszköztár lehetőségeinek a felmérése válik fontossá." TARJÁNYI Eszter: Az érzékelés mesterségesen felnagyitott kultusza és poétikája a századfordulón. (Gondolatok egy kiállítás képei kapcsán.) http://www.c3.hu/ prophil/profi052/tarjanyi.html (2009. 07. 13.)

Ezzel összecseng Mohai V. Lajos szavaival, szerinte minden, amit $A$ mese ,alkonya” elötte írt Szini, és ami „legjelentősebb kötetében az 1913-ban publikált Rózsaszínü hóban olvasható, erre a szálra füződik föl, az elbeszélésnek - ars poétikája szerint - szemléleti értéket kölcsönző mesére.” MOHAI V. Lajos: Mellözöttség, feledés. (Egy múlt század eleji kávéházi író mellőzöttsége.) Új Forrás, 2007/9. 113.

${ }^{375}$ Tarjányi Eszter nagyon fontos észrevételeket tesz e témával kapcsolatban a modernitás törekvéseit a Nyugat első évfolyamának első számában olvasható két értekező szövegben vizsgálva, mintegy „melléktermékként”. Adynak A magyar Pimodán első része, mely „az alkotói oldal felöl” illetve A mese „,alkonya” címủ Szini szöveg, ami „a megszólalás módozata” nyomán igyekszik átgondolni az irodalom lehetőségeit. Az értekező próza vizsgálata azért is lényeges még, mert felhívja a figyelmet arra, hogy ne csak egy jellegzetes századfordulós, szecessziós magatartásformát és művészetfelfogást lássunk a müvészeti útkeresés mögé, ne kizárólag a freudizmus hátterével számolhassunk..." Vö. TARJÁNYI Eszter: Az érzékelés mesterségesen felnagyitott kultusza és poétikája a századfordulón, i. m.

${ }^{376}$ TARJÁNYI Eszter: Az érzékelés mesterségesen felnagyitott kultusza és poétikája a századfordulón, i. m.
} 
hiánytalanul értelmezi és nem sugalmazza a jelkép tartalmát". ${ }^{377}$ Ugyanakkor az előbbi két novellával ellentétben $A$ sétapálca-erdő a mese müfaji és szemléletmódbeli jellemzőivel dialogizálva olyan, az elbeszélés szerveződést is tematizáló szöveg, amelyben - miként Lovik Károly Árnyéktánca kapcsán arra Thomka Beáta rámutatott - „a képzelet világa fölérendelődik a tények világának". ${ }^{378}$

A sétapálca erdő címü elbeszélésben, ${ }^{379}$ a két szereplő (a kis Tamás és nővére, Piroska) párbeszédes szövegrészei szervezik a történetet, a novella nagy részét kitevő narrátori szólam mégis látszólag szenvtelen, a „boldogvégződés” tudatában célirányosan haladó mesemondó elbeszélőé. Míg A rózsaszinü hó mesélője, Eliz a várakozást elősegítő, jutalmazó szándékkal mintegy „estimesét” mond, ${ }^{380}$ addig itt az ébredés, az eszmélés aktusaként eleve lehetetlenné teszi, hogy a mese gyermeki fantáziát szolgáló, a szocializációt és az intézményesített vágykiélést segítő jelleget kapjon. ${ }^{381}$ A sétapálca erdő éppen a mesei fantasztikum realizálódása, a közegéből kiszakított történetmondás devalválódása nyomán mintegy a tanmese vagy igaz mese, a „fable convenue” hagyományát követve szervezi az elbeszélést, az idősebb nővér nevelö, felvilágosító szándékának nyomán: „Piroska arra gondolt, [...] hogy milyen szép dolog ilyen világos és nagy gyermekszem előtt megnyitni a világ ismeretét”. ${ }^{382}$

A sétapálca-erdő azonban nem pusztán a novellában tematizált praktikus okokból (ti. a sétapálca nem terem, hanem csinálják) elérhetetlen. A szövegalakítás szempontjából a realitáson nyugvó, tapasztalatilag ellenőrizhető, készen kapott nem helyettesítheti a fantázialogikára épülő imagináriust, e csakis mentálisan, bizonyos nyelvi müveletek nyomán megképződőt. A kisfiú, Tamás szemlélete mintha azt az elbeszélői, retorikai hagyományt idézné, amelyben a logikán alapuló, fogalmi nyelv előtti, figuratív használat negálna minden konvencionálist, ideologikust, így látszólag „a metaforában és a szimbólumban, egyfajta topikában próbálja rögzíteni a mondhatatlant”. A mese metafizikájáról szólva Lukács Györgynek Balázs Béla költészete kapcsán kifejtett mesefelfogását összegezve Földes Györgyi ezek után megállapítja: „a metafora a nyelv

\footnotetext{
377 DoBos István: Alaktan és értelmezéstörténet, i. m. 130.

${ }^{378}$ Szini prózájában Lovik Károlyéhoz hasonlóan paradigmatikus jelentőséget kap ez a jellemző. „A fikció, a legenda, a hiedelem, a mesevilág, a látomás kiegészítője és egyben ellenpontozója a tényleges megtörténéseknek, a valós világnak, [...].” THOMKA Beáta: A pillanat formái, i. m. 70.

${ }^{379}$ A hivatkozás alapja: SzINI Gyula: Lelki kalandok. Grill Károly Könyvkiadóvállalata (Magyar Írók Arany Könyvtára), Bp., 1908. 71-80. A továbbiakban: SzINI Gyula: A sétapálca erdö. = Uö.: i. m. és az oldalszám. Lásd még: SzINI Gyula: Rózsaszínü hó. (Vál. és bevez. tan.: Vargha Kálmán.) Magvető, Bp., 1963. 111-118.; illetve Uö.: Különös álmok. (Vál.: Téglás János.) Szépirodalmi, Bp., 1983. 101-109.

380 „Ha jól viselkedik, - ígérte - mesélni fogok...” Vö. SzINI Gyula: A rózsaszínü hó. = Uö.: i. m. 4.

${ }^{381}$ Vö. David RIESMAN: A mese és a technika; a karakterformáló tényezök alakulása. Uö.: i. m. 151-152.

382 SzINI Gyula: $A$ sétapálca erdö. = Uö.: i. m. 72.
} 
fejlődéstörténetében is előbb született meg, mint a szó, a használattal később elkopott eredeti jelentése, és ezzel együtt lassan kifejező ereje is, ám még sokáig hordozta a dolgok összefüggésének titkos szálait". ${ }^{383}$ Michel Foucault ehhez nagyon hasonló megállapításokat tesz a szavak és dolgok viszonyáról, a nyelv előtti nyelv, a mesék alapját is adó kezdeti megnevezések kapcsán: „az emberiség kezdeteinél, amikor még csak kevés szó volt, a reprezentációk pedig zavarosak voltak és rosszul elemezték őket, amikor a szenvedélyek módosították és összeolvasztották öket - ekkor tehát a szavaknak nagy volt a helyváltoztatási képességük. Sőt elmondhatjuk, hogy a szavak először átvitt értelműek voltak, mielőtt saját jelentésre tettek volna szert". 384

A szövegtérben mozgó metaforikus kifejezések nyomán a mese alapját is képező fantázialogikára épülő szemléletmód a kisfiú alakjához kapcsolódva „,a nyitott szemmel álmodásban” ezt a viszonyítás alapját képező elbeszélői hagyományt idézi meg:

„Nyitott szemmel erről a csodálatos erdőről kezdett álmodozni. Milyen is lehet az? Ott terem az a csontnyelü, gólyafejü pálca, amilyet az apja visel; ott nő az a vaskos, tigrisszínü bot, amelyre a nagyapja támaszkodik, ott fakadnak a fekete pálcák, amelyeknek a nyakán ezüstvirág, csontgolyó vagy égszínủ drágakő nő ki. Hogy susoghat, csilloghat mindez, és csak le kell őket metszeni. És kis bokrokban ott vannak együtt a gyerekek pálcikái. Lófejü, piros kutyafejü, madárfejü pálcikák, amik közül némelyikbe bele lehet fújni, hogy úgy fütyüljön, mint a rigó. Elszédült belé, ha arra gondolt a sok közül melyiket fogja választani." 385

A fantázialogikában felsejlő mitikus, a titkos szálak zavaros elvontsága helyett azonban itt már inkább a fizikai kézzelfoghatóságot, a primer birtoklási vágyat kísérő, azt lehetővé tevő megnevezés, a nyelvi megragadhatóság áll. Ebben a verbális aktusban pedig elsősorban a hasonlóság, a két tárgy közötti valamilyen szempontból vont analógia a maghatározó. A konkrét-átvitt irányba mozgó nyelvi mủvelet ,a kis álmodozó” esetében, olyan hasonlóság-alapú áthelyezés, melyben a metaforikuság szempontjából is meghatározó szelekció és kombináció kognitív müvelete közül elsősorban a kiválasztás érvényesül. A jakobsoni alaptétel elemei közül - amelyek már esetében sem csupán a

\footnotetext{
${ }^{383}$ FöLDES Györgyi: A mese metafizikája és a magyar avantgárd. (Balázs Béla, Lesznai Anna és Kassák Lajos meséi.) Irodalomtörténet, 2000/4. 530.

${ }^{384}$ Michel FouCAUlT: A szavak és a dolgok. Ford.: Romhányi Török Gábor. Osiris, Bp., 2000. 141.

${ }^{385}$ SzINI Gyula: A sétapálca erdö. = UÖ.: i. m. 71-72. [A kiemelés tőlem. B. S. A nyomdatechnikai okokból kizárólag rövid 'ü', 'i'-ket szerepeltető első kiadás szövegét vettem alapul, de a későbbi megjelenéseknek megfelelően ezeket hosszú magánhangzókra cseréltem.]

Az idézett rész utolsó mondatának mentális- és fizikális állapotot egyaránt befolyásoló felismerése értelmezhető úgy is, mint amiben ez a nyelvi birtokbavétel nyomán keletkező kihívás, feladat jelleg „kap hangot”. Talán az egyszerü 'beleszédülni valamibe' köznyelvi fordulaton túl jelentőséget lehet annak tulajdonítani, hogy Déry Tibor Szerelem címü elbeszélésében is éppen a nyelvi megragadhatóság kérdésköre, a metaforikus müködés felismerése, ,az érinthetőn át az érinthetetlent” tapasztalata nyomán a főhős hasonló módon megszédül a felismerés súlya alatt. („Addig nézte a kettőt, az érinthetőn át az érinthetetlent, amíg el nem szédült.”) Lásd a disszertáció Déry-fejezetét.
} 
költészetet jellemző poétikai funkcióként, inkább „a nyelvi viselkedésben használt két alapvető elrendezési” módként jelenik meg ${ }^{386}$ - a metaforizáció ilyen típusú folyamatában egyszerű névátviteleket eredményező hasonlósági alapú, azaz szelekciós áthelyezésről van szó. ${ }^{387}$ A megszövegezés egyik alternatívájaként ez a nyelvi viszonyulás értelmezői munkát nem igénylö, eminens diákosan részletező és pedáns, monologikus módon pedig leginkább a saját fantázia- és álomképének artikulációját szolgálja.

A sétapálcák, pálcikák saját elképzelésére, vágyaira és álmaira szabott verbalizációja során a „kis álmodozó” Tamás ugyanakkor teresíti az elemeket, egy az egymásutániságon alapuló, szekvenciális folyamat során azt a rögzített, rögzíthető helyet keresi, ahonnan a dolgok erednek, ahol a sétapálcák sarjadnak. Fantáziája, és az ebből táplálkozó nyelvi megnevezés igazolására, konkretizációjára vágyik, eltávolodva a tisztán fantázialogikát müködtető mesevilágtól. ${ }^{388}$ Kalandjában két tudatforma kerül egymás mellé, szembesül egymással: az álmaitól a sétapálca-erdőbe vezető utat övező táj ennek a köztes állapotnak a képlékeny territóriuma.

Tamás nővére, Piroska, szerepkörének megfelelően a világ megismerésének, az új információ megszerzésének a szó átlátszóságára, a magától értetődő egyértelműségére, megnyugtató kiszámíthatóságra épülő eszközjellegére apellál. Egyszersmind az archaikus tapasztalattól eltávolodva (a Northrop Frye által metaforikus nyelvi fázisnak nevezett állapot helyett) a tudományos gondolkodásra jellemző nyelvhasználatnak a referenciali-

\footnotetext{
${ }^{386}$ Roman JAKOBSON: Nyelvészet és poétika. = UÖ.: Hang - Jel-Vers. Gondolat, Bp., 1969. 223-224.

${ }^{387}$ Ez nyelvi müvelet tehát egy már létező állat konkrét, rá használt nevét helyezi át az eddig nem egyedített sétapálca tulajdonságának megnevezése érdekében, átvitt ételemben használva az élölény egyik jellemzőjét (fejforma, szín stb.) kiemelő szót. A gólyafejü pálca, tigrisszinü bot, vagy a lófejü-, (piros) kutyafejü-, madárfejü sétapálca a szövegben - a nyelvi kép fajtáinak Kemény Gábor által használt csoportosítását követve - jelölt, motivált, explicit kép, olyan tömörített hasonlat, melyben ,,a képi elemet valamely -ú, u képzős összetett melléknév előtagja hordozza”. Az azonosítás alapját ebben az típusú képben ,,az összetételi utótag jelöli meg, a kifejezendő tárgy a melléknévi jelző jelzett szava, végül a konstrukciót modalizátorként a melléknévképző fogja össze". A szerkezet ennek megfelelően transzformálható egyszerü hasonlattá [,,angyalfejü gyerek” - „A gyereknek olyan a feje, mint az angyal(ok)é.”], a befogadónak semmit sem kell »kitalálnia«, önmagából - értelmezésként - a szöveghez hozzátennie. Az ilyen kép már alkatából eredendően is igen részletező, pontos, néha szinte már didaktikus, sőt pedáns" - fogalmaz Kemény Gábor. Miként azonban arra maga is figyelmeztet: „Ez azonban korántsem jelenti azt, hogy e típus eleve csökkentett értékü, hiszen sokszor épp ilyen képre van szüksége az írónak, ez a megoldás adekvát funkcionálisan". Külön érdekesség, hogy a szerző gyakorisági vizsgálata alapján éppen Krúdy Gyula prózájára jellemző az -ú, -ü képzős tömörített hasonlat nagyobb arányú használata. Vö. KEMÉNY Gábor: Bevezetés a nyelvi kép stilisztikájába. Tinta, Bp., 2002. 120-121, 125, 137.

388 A még nem megismert, reális, hétköznapi, és a már nem átélhető képzeletbeli, mesei határán mozogva mégis a mesevilág ontológiáját követve, „szép kék bársonyzekéjében” mesehősként indul a rengetegbe, miközben „,világában képzelet és gondolat, érzület és cselekvés, szavak és dolgok teljes egységet alkotnak. Közvetlen út vezet az ötlettől a tettig, a lehetőségtől a valóságig”- ő pedig csak „,ment a híres sétapálcaerdő felé". KIRÁLY Jenő: A mesevilág ontológiája. = Uö.: Frivol múzsa. (A tömegfilm sajátos alkotásmódja és a tömegkultúra esztétikája.) 1. kötet, Nemzeti Tankönyvkiadó, Bp., 1993. 254. Vö. SzINI Gyula: $A$ sétapálca erdö. = Uö.: i. m. 72.
} 
tásba vetett feltétlen hitére hagyatkozik. ${ }^{389}$ A sétapálca nem a képzelet által megragadható, egyedített és trancendens anyagszerüségében létező, inkább egy használati tárgy, melyet praktikus céllal, anyagi, esztétikai stb. okokból valamilyenné formálnak, gyártanak: ${ }^{390}$

„Piroska arra gondolt, mikor a csöpp és komoly emberkére pillantgatott, hogy milyen szép dolog ilyen világos és nagy gyermekszem előtt megnyitni a világ ismeretét. Hogy amikor az erdőbe fognak érni, mint fog a kis buksi csodálkozni, ha nem látja a sétapálcákat. Akkor aztán szépen meg lehet neki magyarázni, hogy: lásd, kis bölcs barátom, erről a leveles ágról csak le kell fosztani a leveleket, le kell hántani a háncsot, és készen van a friss pálca, amelyet az esztergályos kicsiszol, a festő megfest, az ékszerész arannyal, ezüsttel vagy drágakővel csinosít." ${ }^{\text {391 }}$

A lánytestvér is teleologikus módon, tanító és felvilágosító szándékától vezérelve, csak ő a fantázialogika ellenében, a referenciális fel- illetve megmutatása felől, a nyelvi rendszerbe való beléptetéssel igyekszik szocializálni, a szimbolikus rendbe integrálni kisöccsét. ${ }^{392}$ Látszólag a betagozódás sikerességét, az illúzióvesztettség keserű tapasztalatát követő felismerést, valamint a szöveg csattanóra kihegyezett, Piroska elképzelését beigazoló, tanmeseszerü és megnyugtató olvasatát erősíti a kis hős, Tamás hangsúlyos verbális megnyilvánulását előlegező magyarázó rész a novellában. ${ }^{393}$

A megnyilatkozás vagy önkifejezés alternatív formájaként a „beszédes férfi” sétapálcája Tamás kezében végül olyan eszköz, amely a nyelvileg nem artikulálhatót, a fogalmilag nem megragadhatót egy más jelrendszer, ha úgy tetszik egy „nyelv előtti nyelv” használatával adja nővére értésére. Piroskának a tanítás eszközét jelentő sétapálca Tamás kezében válik a tanulság megfogalmazásának eszközévé, amivel „nővére értésére adja” felismerését. A tanító-tanított, felvilágosító-felvilágosított viszony felcserélődése, és a

\footnotetext{
${ }^{389}$ Frye könyve, a Kettős tükör a nyelv fejlödésének három (a metaforikus, metonimikus és a referencialitás nyelvi) fázisát megkülönböztető szemléletére alapozza megkülönböztetését. Vö. Northrop FRYE: Kettős tükör. (A Biblia és az irodalom.) Ford.: Pásztor Péter. Európa, Bp., 1996.

390 A megkülönböztetés hátterében a szövegalkotás, az „,irodalom gyártás” Szini esszéjében, A mese „alkonyá"-ban érintett problémaköre is felsejlik. A rossz elbeszélések, a novella-ipar túltermelésében, a mesehagyományt „mesévé”, az egyedi, ősi formát fogyasztási cikké, sorozatgyártott tucattermékké alacsonyítják. Vö. SzINI Gyula: A mese ,,alkonya”, i. m. 26.

${ }^{391}$ SzINI Gyula: $A$ sétapálca erdö. $=$ Uö.: i. m. 72-73.

392 A téma részletes elméleti tárgyalása ehelyütt nem lehetséges, annyi azonban kiindulópontként megjegyezhető, hogy nyelvben és nyelv által létező szubjektum kialakulásának többek között Emile Benveniste, Jacques Derrida és Jacques Lacan elméletére visszavezethető felfogása nem elhanyagolható a Szini szövegeinek olvasata szempontjából. (Jó példa erre Hites Sándornak a Sárga batár értelmezése. Vö. HITES: i. m.) Ezek az alakulófélben lévő, diszkurzusok láncolatába áthelyeződő szubjektum szempontjából „árulásnak”, a vágyak lefokozódásának tünő, a nyelvhasználatot érintő jellemzők nem hagyhatók figyelmen kívül a Sétapálca-erdő értelmezése során. Tamásnak a novellazáró felismerését kísérő elkeseredettsége, a megcsalatottság érzése erre a kiábrándító tapasztalatra is utalhat. Lásd. pl. Catherine BELSEY: A szubjektum megszólitása. Helikon, 1995/1-2. 21.

${ }^{393}$ „Félénken nézett maga körül, és egyszerre az út szélén megpillantott egy botot. A füből szinte kiragyogott. Frissen hántolt bot volt, amelyet valami vándor hagyott ott. A fúben ott voltak még a forgácsok, [...]. Tamás szeme kerekre nyílott. Szinte kilövellt belőle a világosság, amely okos kis agyában támadt. Tanító nélkül is mindent nyíltan megértett. A lecke nyíltan, összefüggöen ott hevert előtte a füben.” Vö. SzINI Gyula: $A$ sétapálca erdö. $=$ Uö.: i. m. 79.
} 
megleckéztetés eme tanító szándéka ellenére a kis Tamás ludas matyis megnyilvánulása és főképp annak narrációja - korántsem e tett poentírozó felszabadultságát, sokkal inkább egy traumatikus felismerés elkeseredettségét visszhangozza. ${ }^{394}$ A mese és metaforikusság, a nyelv és a figurativitás a nyelvhasználat egy korai, a szubjektum szimbolikusba lépésének kezdeti állapotában, alakulási folyamatában találkozik egymással. Tamás „gyönge hangja megerősödve tört ki a torkán, és élesen süvített végig az erdőn,” a világ megismerésének, a nyelvi reprezentációnak két különböző módozataként, más-más hullámhosszon terjedve tova a sétapálca-erdő rezonancia-trében:

„És egyszerre tudatára ébredt annak, hogy megcsalták. Vadul és ellenségesen nézett maga körül. Gyönge hangja megerősödve tört ki a torkán, és élesen süvített végig az erdőn, mint az özikék vészjele:

Piroska! Piroska!

A csalit megzörrent, az ágak ropogtak és két széthajló bokor között megjelent Piroska. Tamás megdöbbent a nénje arcától. Fel volt dúlva, mintha vékony korbácsütések szántották volna, zilált haján a konty félrebillent, szeme félig le volt hunyva, mintha álmodnék. Egy tüskés ágon fennakadt az alja, és látszott vékony lába, amely remegett, mint az őzike bokája. Csak az aranygombú botot nyújtotta, a szava csupán lihegni tudott:

- Várj... mindjárt itt... nesze, addig itt az aranybot.... Keresünk másat... másikat...

Otthagyta a botot és megbotolva, tántorogva indult vissza s sürüségnek. Tamás nézte az aranybotot, a szeme szikrázott. Felkapta a pálcát, és utánaszaladt a leánynak. Végighúzott gömbölyü hátán.

Az ütésre a leány derekában visszafordult, visszacsavarodott, és megpillantott a Tamás nagy, mély szemét, amelyböl a könny csak úgy patakzott.

- Tamás! - szólt meghökkenve, és végigsimította a maga égő homlokát. Hủtött a kezével lángoló orcáját. Hirtelen az aljához kapott és lesöpörte.

- Dobd el azt a botot - szólt halkan. - És menjünk... - Elkezdtek visszafelé szaladni, haza." ${ }^{395}$

Piroska „megejtése”, ártatlanságának, ha nem is elvesztése, de veszélybe kerülése a novellában nem pusztán a „felvilágosítani van olyan öröm, mint felvilágosodni” tétel tanulmányi kirándulásszerü beteljesítéseként érthető. Az esetleges nemi aktust nem kíséri verbális megerősítés, a szövegben megjelenő erotikus szcéna hipnotikus hatásának teleologikussága, örömelvü gyakorlatának célirányossága felfüggesztődik, felülíródik a szerzői szövegalakítás beszédes figurájának fel- és eltünésével. A hajadon nővér külsejének átformálásáért nem a ,szőke bajuszos” idegen okolható: a lány eltévelyedése tropológai jellegü, a külsérelmi nyomok a sétapálcára támaszkodva a sétapálca-erdőbe vezetnek.

A lánytestvér arcát felszántó „,vékony korbácsütések”, a „tüskés ágon fennakadt” alsóruházata, a csalitosban remegő „őzike bokája” a sétapálca-erdő jellemzőit, annak reális

\footnotetext{
${ }^{394}$ Még akkor is, ha mindez olvasható az Ady-írás sokat idézett passzusának szó szerint a Szini-szöveg főhőse által, a sétapálca-erdő hajtásával végrehajtott beteljesítéseként: „olyat ütött a közízlésre....”Vö. ADY Endre: Szini Gyula. Nyugat, 1909/1. http://www.epa.hu/00000/00022/00024/00535.htm (2008. 05. 06.)

${ }^{395}$ SzINI Gyula: $A$ sétapálca erdő. $=$ Uö.: i. m. 72.
} 
tárgyi elmeit hordozzák. Az azonban, hogy az idegen fizikális hatásának, az aktus megtörtének semmi jele sem látható Piroskán és a szövegben sem, feltehetően elsősorban nem Szini novellisztikájának szemérmességével magyarázható. A kijózanító ütleg hatására ugyan nem csak a reális és irreális, álom és valóság cserélődik fel, („Tamás megdöbbent a nénje arcától. [...] Fel volt dúlva, [...] szeme félig le volt hunyva, mintha álmodnék”) Tamás az őzikék vészjelét hallatva, előcsalja a bozótból a narráció során ezen állatok attribútumait felvevő nővérét (,Egy tüskés ágon fennakadt az alja, és látszott vékony lába, amely remegett, mint az őzike bokája”), és mindez nem véletlenül éppen a sétapálca-erdő közegében zajlik.

A dolgok korábbi átlátható, megnyugtató és kitapintható rendje az idegen, a Másik aranygombú botja által, annak eszköz jellegű többértelmüsége nyomán a testi jelzések, süvítő vészjelek aborális territóriumává, ${ }^{396}$ a hasonlóság változékony, kietlen tartományává változtatja a sétapálca-erdő kies táját. ${ }^{397}$

A novella nagyon is beszédes, mégis névtelen, titokzatos idegenjének megnyilvánulása, valamint a leíró, tájábrázoló jellegü narrátori szövegrészek, látszólag késleltető szerepükkel, egy korántsem lineáris, metonimikus történetmondást szolgáló, nyelvhasználati hagyományt és narratív aktust sejtetnek. A szövegalakítás szintjén a metonímia, ok-okozati stb. elvére épülő linearitás, vagy Tamásnak a sétapálca-erdő elérésére fordított célirányos, „szótlan” igyekezete - akárcsak a testvérpár erdei sétája során - a természet jelenségeinek, a sétapálca-erdő lényeinek jelbeszédével szembesül:

„Az erdő szélére értek, és gyér fák közt jártak. Ám egyszerre sürüsödni kezdett, mély árnyékok tátongtak mindenfelöl a fák között, izgalmas nesz támadt a bokorban, és egy éles, vékony hang füttyös jelt adott. Tamás összerezzent.

A vészjel megismétlődött, és Tamás nem mert többé egy tapodtat sem mozdulni.

- Ne félj, Tamás - intette Piroska -, hiszen tőled félnek. Az erdőben már nincsenek veszedelmes állatok, hanem csak apró, szelíd mókusok, bánatos őzikék, amelyek akkor is megijednek, ha ilyen kis embert látnak, mint te. Jelt adnak egymásnak, hogy meneküljenek." 398

Tamás és Piroska novellazáró inzultusa „az elbeszélés fényében” értelmezhető e jeladás, a sétapálca jelbeszéd értékü, non verbális stafétabotszerű játékaként is. A változó

\footnotetext{
${ }^{396}$ A 'szájnyílással ellentétes irány', 'szájtól távoli' jelentésben használt anatómiai kifejezés jól tükrözi az elbeszélés említett jellemzöit.

${ }^{397}$ A kies (elhagyatott de szép, kedves) - kietlen (elhagyatott és sivár, zord) szópár beszélt nyelvi gyakran fordított, (a kies mint elhagyatott és kopár, sivár) „helytelen” használata, a szóalakba kódolt közös jegy (elhagyatott) hibalehetősége miatt is találó, utalva a használatban levő nyelvi jelölés felcserélhetőségre, helyettesítésre egymást kiszorító disszonáns jellemzőire. Lásd. H. VARGA Márta: A 'hiány'-t jelentő denominális fosztóképzös melléknevek szemantikai ellentétpárjai. Magyar Nyelvőr, 2005. 129. sz., 104-108.

${ }^{398}$ SzINI Gyula: $A$ sétapálca erdő. $=$ Uő.: i. m. 73. [A kiemelés tőlem. B. S.]
} 
szerepcserék és elmozduló nyelvi mintázatok közegében az idegen sétapálcájával kezében menekülő, „bánatos őzikék módjára” megszeppent Piroskának tanácstalanságában ott a természet közegében, illetve a férfi alakjában megidézett, más típusú nyelv, és jelbeszéd megtapasztalása is, amely kisöccsét szintén szótlanná teszi. E metaforikus áthelyeződés során az alternatív jelrendszer és rejtett tudás az idegen, az ismeretlen férfi figurájához kapcsolódik. Az erdő akusztikájában a „,vékony hang füttyös” jelzése és a megjelenő férfi, aki ,egyszerre fütyürészni kezdett, és az ujjai között megpörgette - a sétapálcáját”, 399 a természet sétapálca-erdő jelleget öltő titokzatosságára figyelmeztet, a reálist az irreálissal elegyítő közegben rejlő összetartozást erősítve. Ugyanakkor e szövegrészben a gondolatjel mint hatásszünet vagy hangsúlyozott fordulat, a tárgy későbbi többértelmü használatát előrevetítő szerzői szövegalakítás jelzése, Szini jelbeszéde.

A beszédes idegen határozottsága, hódításának névfejtő magabiztossága is erre a jelrendszereket, a jelölés folyamatát ismerő biztonságra és kiszámíthatóságra hagyatkozik, a dolgok látható, kölcsönösen egymáshoz rendelt jeleinek értése során. ${ }^{400}$ Nem véletlen hogy ehhez éppen Piroska, - aki korábbi tanító és felvilágosító szándéka során a nyelvi relációkat, a megnevezés referencialitását adottnak tekintette - ő és a neve kölcsönös megfeleltetési, problémátlan megnevezési kapcsolatával a legjobb alany, önként adódó áldozat. ${ }^{401}$ Ebben az onomasztikai fogásban lelepleződik ,a teljesen áttetsző nyelv nagy utópiája, amelyben maguk a dolgok volnának tisztán megnevezve, [...] egy annyira természetes nyelv révén, amely a gondolkodást, szenvedélyt kifejező arcként fordítaná le". ${ }^{402}$

Az elpiruló Piroskát tehát nem csupán szemérmessége okán árulja el kifejező arca, névadó tulajdonsága: arcpírjának nonverbális jelrendszere. A név kimondásával, a megnevezés müködési mechanizmusának felfedésével egyszersmind gazdája elveszti közvetlen kapcsolatát jelöltjével, így a diszkurzus részeként, a narratíva fényében, a

\footnotetext{
${ }^{399}$ SzINI Gyula: $A$ sétapálca erdő. = Uö.: i. m. 73., 74. [A kiemelés tőlem. B. S.]

${ }^{400}$ „- Én tudom, hogy hívják magát - szólt az ember a Tamás nénjéhez. - Hogyan - kérdezte halkan a leány, és a szó úgy tört elő az ajkán, mint a megrebbent madár csőrén az első félénk csirip. - Hogy is hívhatnának ilyen piros arcú, édes szép leánykát másnak, mint Piroskának. Eltaláltam? - kérdezte az idegen. - Igen - hangzott a felelet, immár bátrabban, és Piroska végre rá mert nézni az idegen vékony, lenge, szöke bajuszára." SzINI Gyula: A sétapálca erdö. = Uö.: i. m. 76. E szövegrész metaforikus áthelyeződése révén értelmezői viszonyba kerül a narráció során az eseményeket nem pusztán elörevetítő leírás korábbi szöveghelyével. „Szántóföldek közt mente, a táblákban fürjek bujkáltak és csipogtak...” SzINI Gyula: $A$ sétapálca erdö. =Uö.: i. m. 72. [A kiemelések tőlem. B. S.]

${ }^{401}$ A névhasználat fikciós szövegtérbeli játékával összefüggésben a szereplök kétértelmủ státusát Gérard Genette a metalepszis egyik megnyilvánulásának tartja. Vö. Gérard GENETTE: Metalepszis. (Az alakzattól a fikcióig.) Kalligram, Pozsony, 2006. 33-36.

${ }^{402}$ FouCAULT: i. m. 144.
} 
retorika viszonyainak áldozatul eső, ${ }^{403}$ képlékeny alannyá válik:

„És az ember egyszerre beszédes lett. Elmondta, hogy Piroska haja olyan, mint a vadgesztenye, a szeme olyan, mint a búzavirág, az ajka mint a cseresznye, az orcája mint a rózsa. Tamás pedig csodálkozott, hogy ezt még eddig nem vette észre, sőt hogy most sem tudja észre venni. A cseresznye például, amit Tamás is szeretett, gömbölyü, a Piroska ajka pedig keskeny és finom volt. Az idegen azt is elmondta, hogy amióta csak álmodozni tud, mindig olyannak képzelte el a legszebb lányt, mint amilyen Piroska. Ezt Tamás el is hitte neki, mert odahaza a szülei is a Piroska háta mögött ezt mondták." ${ }^{, 404}$

Az ismerkedés megnevezési aktusát tehát, a nyelvi és fizikális megragadhatóság következő lépéseként, a becéző retorika, a hasonlóság immár többértelmü és megtévesztő felvázolása követi, mely - szemben az egyszerü (piros-Piroska) névátvitellel - a metafora hasonlósági relációját adó, a szövegkörnyezet stb. viszonylatában változó, azaz értelmezésfüggő eljárás. Az udvarlás szóvirágos szólamai mögött, azok hátterében a metaforicitás alapját képező másfajta szemlélet húzódik meg, mint a megnevezés esetén. A finom szó többértelmüsége ('izletes' illetve 'kecses') nyomán a szövegrész rámutat, hogy nem a hasonlósági viszony, a tárgyi és képi elem közötti kapcsolat megtalálása jelent problémát a kisfiúnak sem, hanem mindössze befogadói és nyelvszemlélete okán képtelen Tamás ennek felfogására: nem ismeri fel azt. Inkább az eddigi jelölési gyakorlatának megfelelően a névátvitel egyszerü megfeleltetési eljárását követi.

Tamás rácsodálkozását tehát, nem kisfiús szemérmessége, vagyis a nyelvi eroticizmus koránál fogva ismeretlen vetülete, sőt nem is korlátozott szellemi képessége okozza. A „kis ember” és az idegen férfi mindössze másként álmodozik, eltérő értésmódot, fantázialogikát müködtetnek. ${ }^{405}$ A Sétapálca-erdő című novella hátterében meghúzódó, és részben a szövegben tematizált, a szereplőviszonyokat meghatározó szerzői dilemma az ábrázoló és mesélőeljárás oppozíciójában ragadható meg, ${ }^{406}$ melyben A mese „alkonya”

\footnotetext{
${ }^{403}$ „Az alakzatok, amelyeken a diskurzus áthalad, a név késleltetését biztosítják, amely az utolsó pillanatban tölti ki és szünteti meg őket. A név a diskurzus végpontja. [...] Itt a megnevezés végre a maga legegyszerübb mezítelenségében mutatkozik; a retorika alakzatai, amelyek eddig függőben tartották, meginognak, és a vágy meghatározhatatlan alakzatai lesznek, amelyeket ugyanazok az egyre ismételt nevek szakadatlanul áthatnak, anélkül, hogy elérhetnék ezen vágyalakzatok határait.” Vö. FOUCAULT: i. m. 144-145.

${ }^{404}$ SzINI Gyula: $A$ sétapálca erdő. = Uö.: i. m. 76-77. [A kiemelés tőlem. B. S.]

${ }^{405}$ A két testvér, a természet jeleit, az állatok jelbeszédét és a sétapálcás férfi metaforikus kifejezéseit is korábbi ismereteikhez (,Ezt Tamás is elhitte neki, mert odahaza...”) igazították, kész nyelvi és befogadói sémákat, közhelyszerü fordulatokat (,- Ne félj, Tamás - intette Piroska -, hiszen töled félnek”), szólásmondás sablonokat („Kis ember jobban a lába alá lát”) - a nap által az útra terített szőnyegként követtek ahelyett, hogy értelmezték, a jelölési folyamat során újratételezték volna, mintsem egyszerủen beazonosítsák, felismerjék a hallottakat. Eközben pedig - akárcsak a saját elképzelésükre az idealizál kis állatkák - „sütkérezve mászkáltak tágas, napos országútjukon”. Vö. 418. lábjegyzet.

${ }^{406}$ Király Jenő az esztétikumok sajátosságairól szólva, nagyon is indokolt módon, e két fikcióteremtő módszer fantázialogikai jellemzését tartja indokoltnak „Az ábrázolóérzék számára az, ami mindennél érdekesebb: nem történt meg. A mesélők úgy érzik, hogy a legjobb dolgok még nem történtek meg, ami történt, nem méltó hozzájuk.” KIRÁLY: i. m. 99-100.
} 
címủ esszével összecsengve a mese és novella megkülönböztetése is érzékelhető. ${ }^{407}$

A „szőke bajuszos” célja nem az igazságról való meggyőzés, az ismeretekhez segítő magától érthetőség, hanem az, hogy „lebeszélje Piroskát a lábáról”. Ehhez pedig a legideálisabb közeg a figurativitásé; a jelölők csalfa játékának, az illuzórikusságnak és megtévesztésnek képlékeny területe, ahol a metaforikus nyelv szemfényvesztése adja az idegen kezébe a „sétapálca-erdő legszebb hajtását”. ${ }^{408}$ Eközben pedig a jelölőben a jelölés folyamatának mechanizmusa is megfigyelhetők, a megnyilatkozás nem pusztán a kifejezés módja, hanem az a mód is, ahogyan kifejezés megformálódik. Ettől korántsem függetlenül - Dantónak az irodalmi szövegek metaforikuságáról tett észrevétele szerint - „a metafora tehát prezentálja tárgyát és ezen túlmenően azt a módot is, ahogyan prezentálja azt”. ${ }^{409}$

A „beszédes férfi” praktikus, bizonyos szempontból gyakorlatias szemléletének hátterében mégis a retorika Piroskáétól eltérő megítélése, az egyértelmü megnevezés metaforikus alternatívája áll. Kezében aranygombú botja nem eszköz valami megfogalmazására, inkábba a sétapálca(-erdő) kifejezés alkalom, ürügy valami másnak, éppen a magától értetődőnek az elfedésére. Így „macsós” szövegelései sem az egyszerü névátviteleket eredményező hasonlósági alapú, azaz szelekciós áthelyezést követik, hanem sokkal inkább „olyan metaforizálási folyamatot mutatnak, a melyben a metafora tenor része egy absztrakt világalkotó, hordozója pedig egy konkrét kép egysége. A szövegben viszont mint állapotok leírásai jelennek meg, vagyis a metaforizáltságuk nem tủnik szembe". 410

Tamás döbbenetes felismerése, és az azt nővére tudtára adó megnyilvánulása egyszersmind a szerelmes pár - látszólag széttartó, de egyaránt a „szent célt” szolgáló retorikájára mért ütés. Kezében pedig a sétapálca és a sétapálca-erdő, mint jelölő és hozzá kapcsolódó jelölt egy jellé, a természet és a fikcionalitás kifürkészhetetlen, megismerhetetlen sötét tartományának jelbeszédévé válik. Annak a közegnek a nyelvévé, melybe legotthonosabban a szerzői figura, a narrátor mozog. ${ }^{411} \mathrm{O}$ az, aki, A sétapálca-erdő

\footnotetext{
${ }^{407}$ Vö. a Szini-esszé záró anekdotájával. SzINI: A mese „, alkonya”, i. m. 27.

${ }^{408}$ SzINI Gyula: $A$ sétapálca erdö. = Uö.: i. m. 74.

409 Artur C. Danto: Metafora, kifejezés és stílus. Ford.: Sajó Sándor. In: BAcsó Béla (szerk.:) Szöveg és interpretáció. Cserépfalvi, Szekszárd, é.n. [1991.] 149.

${ }^{410}$ BÓKAY Antal: Szövegstruktúra, szövegvilág és irodalmi interpretáció. Literatura, 1981/1-2. 53.

411 Szerzői figura, a narrátor mint a szerző alakjához - többszörösen lebontott és újrarendezett módon kapcsolódó alak(zat), a szerző és narrátor szólamának, szerepkörének tropikus szerveződésének tárgyalása szétveszítené e disszertáció kereteit. Mégis a metaforikusság kiterjesztett vizsgálata, a trópusok legkülönbözőbb elemeket össze- és újrarendező felfogása a társadalom- és történelemtudományban, a kultúra és viszonyrendszerében lehetővé illetve szükségessé teszi e szempont érvényesítését. Ennek kiindulópontjaként lásd: „Ebben az együttesben a retorikai vagy felváltja, vagy kiegészíti a narratív funkciót, ami az értelmező olvasat számára is alternatívát jelent. A figuratív okozatiság elve szerinti elbeszélésben az alany maga is metaforikus.” Vö. THOMKA Beáta: Glosszárium. Csokonai, Debrecen, 2003. 15.
} 
„vadőreként” a szöveg, az írás jelölőit, a nyelv elötti nyelv, a nyelvi emlékezet, a természet létezőivel, és ezek jelzéseivel társítja. Egyszersmind saját szerepét, tevékenységét metaforikusan e szövegtér részeként, müködésével pedig mindezeket fel- és megidézhetőként tételezi. A narrátori szólamba így értehető(bb) módon szürődnek, szövődnek bele - a metonimikus előrehaladást, a történet elbeszélésének teleologikusságát megakasztva - a szerzői szövegalakítás, a retorikai gépezet megnyilvánulásainak erösen metaforikus felhangjai. Hiszen „a reprezentált dolgokban hangzania kell a hasonlóság szakadatlan morajának; a reprezentációban pedig jelen kell lennie a képzelet állandóan lehetséges visszhangjának, és e két követelmény egyike sem lehet meg a másik nélkül, amely kiegészíti és szemben áll vele": ${ }^{412}$

„Minden szavuk ünnepiesen visszhangzott az erdőben. Olykor méhdöngés vegyült bele, amint a nap egy keskeny résen beférkőzött, és beletüzött egy vén, mohás fa odvába, amely körül vadméhikék raja táncolt. Az odvas fától egy másikig a pók feszítette ki a hálóját, amelynek minden szála szivárványosan csillogott, és csalogatta az arany legyeket.

- Erre mondta az idegen -, erre tudok én nagyon szép pálcikákat. [...]

Piroska még mélyebben hajtotta la a fejét. Az idegen megfogta a lány kezét, és vitte magával a mohos szálfák karcsú dereka között. Az ág ropogott a lábuk alatt, és szétszakított pókhálók foszlányai tapadtak Piroska arcához. [...]

Tamás szeme a sürüségben fürkészett, a kis szíve lázasan vert, és a méhdöngés mint valami mesemondó hang zümmögött a fülében. Vajon mikor nyílik meg a sűrűség, mikor találják meg az aranynyakú, rigócsőrü pálcikákat. És aggódni kezdett.

A tündérmesék szipirtyói, lidércei jutottak az eszébe, amint a néma, sötét csalitosba meredt a szeme. Félénken nézett maga körül, és egyszerre az út szélén megpillantott egy botot."

Az szereplők szavai - miként az erre reflektáló kifejezés a narrációban - „ünnepiesen”, különböző indíttatásból és nyelvhasználat felől, de egyaránt a nyelv eszköz jellegü visszhangját erősítik, melyben a finoman felcsendülő, másik felhang, újabb zajszint nem más, mint a szerzői szövegalakítás metaforikus zúgása, a nyelviség „,szakadatlan moraja”. A jó mesemondó méhdöngésként egy „vén, mohás odvas fából” kiszüremlő vokalizációja, mely a hallott és látott létezőket, a világ nyelvi elemeit saját ízlésére, partitúrájára formáló eljárás megnyilvánulása. ${ }^{414}$

A „nincs új a nap alatt” felismerés ellen dolgozó nap(sütés), a retorika virágát, a

\footnotetext{
${ }^{412}$ FoUCAULt: i. m. 90. Lásd még „A nyelv teljes terjedelmében és a legősibb hangokig, amelyek első ízben a kiáltásból szakadtak ki, megőrzi reprezentáló funkcióját; az idők kezdetétől minden tagolódásában állandóan megnevezett. A nyelv önmagában tekintve megnevezések fülsiketítő zúgása csupán, amelyek fedik egymást, sürüsödnek, elrejtőznek, összetartva egymást, ami lehetővé teszi a legbonyolultabb reprezentációk elemzését vagy megalkotását." Vö. i. m. 128.

${ }^{413}$ SzINI Gyula: $A$ sétapálca erdő. = Uö.: i. m. 77-78. [A kiemelés tőlem. B. S.]

${ }^{414}$ Olyan müvelet, mint - akusztikai helyett, vizuális metaforikára váltva - A mese „alkonyá”-beli új facette, faszetta, vagyis az „,igazi keleti drágakövek”-ként ragyogó, régi és értékes mesék egyetlen még csiszolható felületének megmunkálása, amitől az - akár az így elképzelt mesehagyomány - „valóban új és művészi”.
} 
napraforgót is mozgató fényforrás az, mely Szini novellájában biztosnak hitt utat jelentő szőnyeget terít a szereplők elé. ${ }^{415}$ Miközben a beszürődés, beférkőzés szerzői szövegalakító játékában, a mesék, mítoszok világát, hagyományát integráló narráció során, egymásra vetíti és összeköti saját közegét (retorikai működését), ezek ősi archaikus tapasztalatával. ${ }^{416}$

A textust, textúrát - miként hálóját a pók - szövögető elbeszélés, ${ }^{417}$ a nap metaforájának fényében, értelmezői hozzáállástól függően, retorikai szemfényvesztéssel szedi áldozatait, vezeti félre az olvasót, a gyanútlan turistát, rutintalan természetjárót. A környezet jeleit értelmezni nem hajlandó, bejárt és ismert nyelvi utakat követő szereplők, a sétapálca-erdő szövegterében értetlenül botladoznak, a nyelv és a világ más típusú tapasztalatát ismerő ,idegenre”, idegenvezetőre szorulnak. ${ }^{418}$ Eközben át- és túllépve az ismeretlen természeti- és nyelvi közeget, zavaró akadályként szembesülnek a célirányosságukat meg-megakasztó, meglévő elképzeléseiknek gátat szabó és a bejárni vágyott útvonalaikat keresztezni igyekvő akadályokkal: a metaforikus szövegalakítás, a más(ik) közegének és szemléletének; a szerző jelbeszédének nyomaival.

A sétapálca-erdő így végül, ennek a nyelvhasználati zónának, a megszövegezés során a térképzés tropikus tartományának közege, ahol ,a szavak helye nem az időben van, hanem egy térben, ahol megtalálhatják eredendő helyüket, eltolódhatnak egymáshoz képest, visszatérhetnek önmagukhoz, lassan leírhatják sajátos görbéjüket: a tropologikus teret. $^{419}$ A sétapálca-erdő ekként pedig literális kontextusával sétapálca-erdő(k) rengetegébe, szövegterek sürüjébe, az elágazó ösvények kertjébe vezet.

\footnotetext{
415 „Tamás bátrabb lett, kivált mikor száz lépésnyi út után a fahegyek közül beömlött a nap sugárkévéje, és eleven, aranyos szőnyeget terített az útra. [...] Kis ember jobban a lába alá lát, és Tamás nem győzte elkerülni a vöröshangyákat, a zománcos bogarakat, a prémes hernyókat, amelyek lassan, sütkérezve mászkáltak tágas, napos országútjukon.” SzINI Gyula: $A$ sétapálca erdö. = Uö.: i. m. 73-74.

${ }^{416}$ A nem reális ismeretekre hagyatkozó tudásból táplálkozó gesztusban ott a verbálisan megragadott tárgy mint egyedi létező immanens jellege is. „Egy kalapácsként használatos kődarab kőségét soha nem éri utol kalapácssága, csak élősködik rajta, hasznot húz a kőtulajdonságok hulladékából” - fogalmaz Király Jenő. „Az eszközvilágban az emberek és a tárgyak egyformán Csipkerózsikák. Az eszköz mögött a dolog transzcendenciája, a szerep mögött a személyiség transzcendenciája elhomályosul.” (Vö. KIRÁLY Jenő: A mesevilág ontológiája, i. m. 250.) Ez a ,szerepen-eszközön túli” megnyilatkozás Csáth által a Cirkuszmulatságban említett „,visszavágyás az ősállapotba, amely korántsem komoly, csak olyan halvány föléledő emlék”. A „mesevilágtól” eltávolodó gyermek szubjektumpozíciója és nyelvi tapasztalat felől, csak egy más hiányfelismerés részeként értelmezhető Garaczi László Pompásan buszozunk! „Jaj, istenem, minek is nőttem meg” felkiáltásában, a gyereknek lenni, odabújni vágyában artikulálódó „visszavágyás”.

${ }^{417}$ Vö. Jovica Aćin: A regény mint pókháló vagy Tolnai Ottó Rovarháza. Új Symposion, 1976/10. 366-368.

${ }^{418}$ Akárcsak a pszichoanalitikus eljárás „,meséltetős” gyakorlatában a páciensek nem nélkülözhetik a terapeutát, azt az „idegenvezető”-t, aki a hátterében álló alaptapasztalatok, a vágy, a tudattalan birodalma, ebbe ,a néma, sötét csalitosba” kalauzol, amely közvetlenül nem, csak narratívák útján, esetleg a psziché kollektív és archaikus emlékezet nyomaiként a mesén keresztül ragadható meg.

${ }^{419}$ FOUCAULT: i. m. 141.
} 
III. Nyelvcsap(ol)ások - a metaforikus próza változatai a mai magyar irodalomban

\begin{abstract}
„Mint tüszúrás nyomán ujjbegyünkből a szurok: elfedek és fölhasítok."
\end{abstract}

Sziveri János: Hasonlat ${ }^{420}$

A metaforikusság prózapoétikai vetületeit érzékelő magyar nyelvü szakirodalom korai kezdeményezései ugyan a nemzetközi fejleményekkel egy időben, az irodalmi interpretációval szoros összefüggésben érintették a metaforikusság kérdését, ${ }^{421}$ mégis az e szempontokat (is) mozgató szövegértelmezések a mai napig kis számban olvashatók, és elsősorban kortárs irodalmi szövegek, esetenként világirodalmi alkotások vizsgálatára vállalkoznak. $^{422}$

$\mathrm{Az}$ értekezésnek ebben a részében egymás mellé helyezett, más-más időszakból származó korpuszok ezért voltaképpen azt hivatottak alátámasztani, hogy a metaforikus prózaszerveződés nem néhány kitüntetett, ekként aposztrofált szöveg sajátja, vagy esetleg a mai magyar irodalom egyik ,új csapásiránya”. A látszólag talán spontán egymás mellé kerülő olvasatok azt hangsúlyozzák, hogy néhány mai, alapvetően eltérő poétikájú szöveg esetében is uralkodó jelenség lehet a metaforikusság, ugyanakkor mint szövegszervező eljárás a már kanonizálódott szerzők, meggyökeresedett szövegértelmezések újraolvasását, továbbgondolását is elősegíthetik. Ekként például Hajnóczy Péter, Balázs Attila, Garaczi László és Kukorelly Endre prózájának értésmódját. „Hangsúlyozottan metaforikus értelmezésre hívnak fel a Garacziéhoz hasonló »anarratív« szövegek, - fogalmaz minderre figyelmeztetve Osztroluczky Sarolta, Garaczi szövegeinek metaforikus jelentésképzését vizsgáló írásában -, melyekben az elbeszélés »folyamatossága« (történetelvüség) helyett hosszabb-rövidebb, egymáshoz nehezen felfejthető asszociativitással kötődő szövegrészek,

\footnotetext{
${ }^{420}$ Vö. Sziveri János minden verse. (Szöveggond.: Utasi Erzsébet.) Kortárs, Bp., é. n. [1996.] 60.

421 Lásd pl. Thomka Beáta: Regényjelenségek, Új magyar regényjelenségek, Metaforikus folyamatok a regényben címü tanulmányait (= Uő.: Narráció és reflexió. Forum, Újvidék, 1980. 9-27., 34-48.) Szegedy-Maszák Mihály: Metaforikus szerkezet Kosztolányi Caligula és Krúdy Utolsó szivar az Arabs szürkénél címü szövegében, és Az Esti Kornél jelentésrétegei szövegeit (= Uö.: „A regény, amint irja önmagát”. Elbeszélő müvek vizsgálata. Tankönyvkiadó, Bp., 1980. 58-71, 103-151.); valamint Kulcsár Szabó Ernö: Metaforikusság és elbeszélés címmel (= Uö.: A zavarbaejtö elbeszélés. Kozmosz Könyvek, Bp., 1984. 62-83. = Müalkotás - Szöveg - Hatás. Magvető, Bp., 1987. 57-93.) az 1980-as évek elején írt tanulmányait, vagy Odorics Ferenc Miképpen értünk meg metaforikus szövegeket? címü írását. (Literatura, 1985/1-2., 14-35.) Továbbá a szegedi irodalomelméleti iskolában, azóta is folyó kutatásokat. Vö. pl. HAJDÚ Péter - RiTOóK Zsigmond (szerk.): Retorika és narráció. Gondolat - Pompeji, Bp., - Szeged, 2007.

${ }^{422}$ Ezt a tendenciát enyhítik némileg a Szó - elbeszélés - metafora címü kötetnek Ottlik Géza, Mészöly Miklós Garaczi László vagy Závada Pál prózáját tárgyaló elemzései. Vö. például a HoRVÁTH Kornélia SzITÁr Katalin (szerk.): Szó-elbeszélés - metafora, i. m.
} 
epizódok sorjáznak." $" 423$

Hajnóczy Péter - e téma szempontjából releváns, de a disszertáció keretei között nem tárgyalható - életművének alig idézett része a testiséget és a szexualitást radikális módon tematizálja. Elbeszéléseiben az excretumok fluiditásának ( $A$ vese-szörp), a testfelület átjárhatóságának vagy a szexualitás és hatalomgyakorlás összefonódásának kérdései (Embólia kisasszony, Nagymama beszáll) a Hajnóczy-próza korábbi jellemzői mellett a metaforikus szövegalakítás módozataival társulnak. Kései kisregénye, a Jézus menyasszonya vagy dráma-szövegei (Dinamit, A herceg) mint testtájak, megnyíló/ megnyilvánuló felületek leginkább a szubjektum megtestesülésének, a test nyelviideológiai behatároltságának zavaró részletei.

A metaforikus szövegalakításnak az intertextualitástól, intermedialitástól korántsem független megnyilvánulásai a mai magyar irodalomban, reprezentatív módon, számos alkalommal a testfelület megnyitásával, a nyelvi megtestesülések hasításai, hasadásai metszésvonalán megnyíló müködésmóddal érintkeznek. ${ }^{424} \mathrm{E}$ megtestesüléseket pedig a korporalitás jeleiként, jelzéseiként többnyire a test nyelvének formációi kísérik, „a nyelv olyan, mint a bőr: szavaimmal a Másikhoz dörgölőzöm”425 - a túlfütött vágyakozását, textuális és szemiotikai praxissá szelídítve. „A test határai szövegekkel vannak kirakva. De a szem, a szem fehérje elmossa a testet, elmossa a szövegek sötétjét. ${ }^{, 426}$ Az összefolyás, fluiditás eme megnyugtató, idilli állapotát követve az olvasáserotika mint értelmezői állapot az élvezet szövegeit a szöveg élvezetévé, a jelölés végtelensége, a nyelvhasználat körkörössége nyomán az elodázás gyönyörévé teszik: ${ }^{427}$ az interpretáció megszakítottságába (csáthi áthallással: a coitus interruptusába) fordítják. Eközben a szövegterek termékeny megnyílásukkal, buja összefonódásukkal az áthágást, az obszcenitást, az egymásba hatolást a szerelmes beszéddé, poétikai jellemzőkké szelídítik. „Jóllehet a szerelmes beszéd csupán alakzatok halmaza, amelyek éppolyan

\footnotetext{
${ }^{423}$ OsZTROLUCZKY Sarolta: „Azért lettem iró, mert féltem...” (Az intertextualitás és a metaforikus jelentésképzés vizsgálata Garaczi László folytatásos önéletrajzi regényében.) In: HoRvÁTH Kornélia SzITÁR Katalin (szerk.): Szó - elbeszélés - metafora, i. m. 222-247. Továbbá lásd Bónus Tibor Garaczimonográfiájának ezzel összecsengő észrevételeit: Bónus Tibor: Garaczi László. Kalligram, Pozsony, 2002. 150., 175.

${ }^{424}$ Lásd Piero Camporesinek a test és vér rítusaival, annak irodalmi szöveghelyeivel foglalkozó „irodalomtörténetét”, mely a korpuszokat a korporalitás formáiként olvassa. Vö. Uö.: Il sugo della vita. Garzanti, Milano, 1997.

${ }^{425}$ Roland BARTHES: Beszédtöredékek a szerelemröl. Ford.: Albert Sándor. Atlantisz, Bp., 1997. 95.

${ }^{426}$ NÉMETH Zoltán: A szem folyékony teste. (Versek.) Ab-Art, Bratislava, 2000. Ezek egyúttal értelmezhetőek a szerző teoretikus munkáinak poétikai vetülete, költészeti formái gyanánt.

${ }^{427}$ „Az olvasás: a hús sima mozgása a papír felett, a szövegben. [...] Az interpretáció perverzitásának müveleteivel segítem elö az önmegértés aktusait..."Vö. NÉMETH Zoltán: Olvasáserotika. (Esszék, kritikák, tanulmányok - az élvezet szövegei.) Kalligram, Pozsony, 2000. 9-10.
} 
kiszámíthatatlan rend szerint bukkannak fel, mint ahogy a légy röpköd ide-oda". ${ }^{428} \mathrm{~A}$ metafora pedig virágzásának színpompája ellenére többé már nem botanikai látványosság, ártatlan szóvirág, inkább a meta-metaforáktól hemzsegő rét, túlburjánzó rizomatikus növénye, ${ }^{429}$ mely - miként napraforgó is - a retorika megannyi virágának egyikeként „a metafora alatt áll...".430

428 Roland BARTHES: Beszédtöredékek a szerelemröl, i. m. 237.

429 Vö. „A rizóma egy gondolkodásmód emblémája: a gyökértörzslogika szemben a gyökeret eresztő fa logikájával. A sokszorosság és a szingularitás lényegileg összefonódnak [...]. Rizóma a legjobb szó a sokszorosságok jelölésére.” Gilles DeleuZE - Felix GuATTARI: Rizóma. Ex-Symposion, 1996/15-16. 1-17. ${ }^{430}$ Jacques DERRIDA: A retorika virágai: a napraforgó, i. m. 32. 
1. , Az érinthetőn át az érinthetetlent..." - Déry Tibor Szerelem című novellájának és

Makk Károly filmjének olvasata

$$
\begin{aligned}
& \text { „Szabadság, } \\
& \text { szerelem! } \\
& \text { E2 kell nekem.” } \\
& \text { Bella István }{ }^{431}
\end{aligned}
$$

A Déry-szakirodalom egyik jellemző tendenciája, hogy bár az életmű kiemelkedő teljesítményeként többek között a szerző 50-es, 60-as években írott elbeszéléseit említi, éppen ezeknek a mai olvasói érdeklődést fenntartó szövegeknek hiányzik a prózapoétikai és egyéb textuális szempontokat is érvényesítő tárgyalása. Ugyanakkor Déry Tibor ebben az időszakban megjelent regényei, elsősorban a G. A. úr X-ben és $A$ kiközösitő az életrajzi, filológiai illetve politikai, ideológiai megközelítéseket kiegészítő újabb értelmezések alapján „az elbeszéltség illúzióját fokozó” megoldásaikkal, groteszk-ironikus látásmódjukkal a 60-as, 70-es évek magyar epikájában „,poétikailag legalább egy évtizeden át mintaérvényünek számítottak". ${ }^{332}$

Felmerül tehát a kérdés, hogy Dérynek a korábbi sematikus, ideologikus ábrázolással némiképp szakító regényekkel párhuzamosan íródott novellái, kisregényei mennyiben tekinthetők a nagyepikai szövegszervező eljárások alternatíváiként? Közelebbről, hogy a tematikus rokonságot mutató ekkori szövegek, így A téglafal mögött vagy a Vidám teremtés, mellett a Szerelem például értelmezhető-e, és ha igen, miként egy a 70-es, 80-as évek prózairodalmát szem előtt tartó, a metaforikus szövegalakítás formáit idéző, vagy ezeket előlegező poétikai, retorikai szempontrendszer részeként?

A Szerelem című novellában a férfi-nő kapcsolat, illetve ennek hiányából adódó elementáris vágy a finom utalás- és motívumrendszer részeként metaforikus viszonyba kerülő szavak összekapcsolásával válik egy általánosabb képzetkör és hagyomány részévé, mely árnyalt, sokrétű értelmezést biztosít e közhelygyanús fogalomnak. A politikai elitélt szabadulásától a feleség karjaiba vezető út azonban a váteszi attitűd romantikus óhajának („Szabadság, szerelem/ E kettő kell nekem.”) 20. századi újraírása helyett, elsősorban nem más, mint az irodalom közegében artikulálódó nyelvi önmegértés-kísérlet. Ebben a

\footnotetext{
431 A legszebb sakkvers. Bella István verse amellett, hogy írásképével ötletesen ironizál egy korábbi költő hagyományt, felidézi a lírai tematikát logikai szövegszervező játékhoz közelítő 20. századi irodalmi törekvéseket is, így Stefan Zweig Sakk novelláját, Tandori Dezső Táj két figurával című versét vagy akár Déry Tibor Szerelem címü, 30-as évekbeli kiadatlan versszövegét: „Süketen kúszom mögötted a napfény és az éj-/ szaka elvesző sakkmezőnyén...” Vö. DÉRY Tibor: Kék üvegfigurák. Elbeszélések (1921-1929) Versek (1916-1937). Sajtó alá rend.: Botka Ferenc, Magyar Irodalmi Múzeum, Bp., 1998. 269.

${ }^{432}$ Vö. KulCSÁR SZABÓ Ernő: A magyar irodalom története 1945-1991. Argumentum, Bp., 1994. 124-126.
} 
megközelítésben nem csupán arról van szó, hogy a szöveg ,az ártatlanul meghurcolt és börtönbe vetett áldozatok sorsát” elbeszélő történelmi parabola, ${ }^{433}$ vagy a „megalázott és szinte tönkretett ember szabadulásának és magára találásának" története, ${ }^{434}$ sokkal inkább egy „sorsesemény személyes narrációvá alakitásának kísérlete”. Ez esetben pedig a szóhasználat illetve szövegalakítás összefüggéseire helyeződik a hangsúly, és kitüntetett szerep jut a trópusként értelmezett szó, a metaforikus szövegszerveződés jegyeinek. Ekként pedig ,a narráció nem annyira a történet reprodukciója” sokkal inkább ,a történet megnevezésére irányuló kísérlet: a (megfelelő) szó keresése”, ahol is „az elbeszélő tevékenységet valamilyen hiány érzete váltja ki”. ${ }^{435}$

A novella szövegében a megelevenedő világ sokszínűségét leíró rész végén tipográfiailag is kiemelkedik a nő (,S a nők!’), a másik nem hiánya, melyet egyelöre a villamoson lezajló párbeszédben résztvevő kalauznő tölt ki, vagy legalább is ez köti le a főhős figyelmét. A narrátori közlésekben ezzel párhuzamosan megjelenő egyes elszórt elemek (alma, fa, kert) a metaforarendszer részeként a korábbi „profán” párbeszéd nőképét ellenpontozzák, és a bibliai hagyomány felé nyitják meg a szöveget. Éppen a szövegbelső ismétlődések révén kialakuló motívumrendszer egyes elemei, az emblémákkal, emblematikus kifejezésekkel ${ }^{436}$ érintkezve, és a szövegstruktúrába ily módon beépülve eredményezik, hogy a felidézett hagyománykör nem elszigetelten, hanem mintegy jelentésgazdagító intertextként viszonyul a mühöz, lehetővé téve ezáltal a szövegek kölcsönös egymásra olvashatóságát, dialogikus viszonyát. ${ }^{437}$

Ugyanakkor a Szerelemben tematizált testiségnek az erószt és szexust egyaránt idéző megjelenítése, az erotika köznapi, profán illetve szakrális, vallási értelmezhetőségének kettősségére is utalhat, mely utóbbi szemlélet ,az erotikában egy mély, ontológiai doktrína tükröződését látta, és pontosan mint Tudást, mint Kinyilatkoztatást fogták fel a szakrális civilizáció képviselői azt a titkos impulzust, amely a férfi szellemi energiáját a

\footnotetext{
${ }^{433}$ Vö. Pomogáts Béla: Déry Tibor. Akadémiai, Bp., 1974. 130.

${ }^{434}$ Vö. Pomogáts Béla: Az emberség ereje. In: Déry Tibor: Niki, Szerelem. Szerk.: Pomogáts Béla. Ikon, Matúra klasszikusok, Bp., 1995. 92.

${ }^{435}$ SzITÁR Katatlin: Szóelmélet és prózaelemzés. In: i. m. 66-67.

436 Emblémának a Bernáth - Csúri szerzőpáros meghatározásával összhangban azok a szövegkülső ismétlődéseket tekinthetők, amelyek már előfordultak más, nem feltétlenül korábbi, de hagyománytörténetben központi jelentöségü „eredeti” szövegekben, s így eleve rendelkeznek valamilyen konvencionális, de az egyszerü köznyelvi használaton túlmutató (emblematikus) jelentéssel. Az interpretáció során az értelmező a szövegszerveződés függvényében valamilyen viszonyt alakít ki ezzel a emblémával (megerősíti, módosítja esetleg figyelmen kívül hagyja). Vö. Bernáth Árpád: Épitökövek. (A lehetséges világok poétikájához.) Ictus és JATE Irodalomelméleti Csoport, Szeged, 1998. Különösen: 20-34.

${ }^{437} \mathrm{Az}$ intertextuális kapcsolat során ily módon a novella szövegmüködése és poétikai megoldásai kerülnek előtérbe, szemben a tematizált külső valóság elemeivel. (Vö. genette-i intertextualitás meghatározással: Gérard GeNETTE: Transztextualitás. i. m. 82-90.)
} 
nőhöz irányítja egy életen át, s egyúttal a nőre való kínzó vágyakozást idézi elő". 438

A novellában az ellenkező nem képzetéhez tematikusan társuló testi vonzalom, vágyakozás a megszövegezés során a kifejezhetőség, a nyelvi birokba vételt kísérő hiánnyal, valamint az önmeghatározás igyekezetével párosul. A mások beszédének e vágyakozást degradáló szentségtörő idegensége csak fokozza a főhős magába fordulását, bezárkózását, az „önuralom”-ként jellemzett némaságát. („B. leszállt, a taxiba ült. A sofőr lecsapta a zászlót. - Hová tetszik? - kérdezte egy idő múlva, mivel utasa nem szólalt meg.",439)

A hazatérést a nemi szervek funkcionális használataként meghatározó örmester szavai („Mehet haza ebédelni a feleségéhez. Éjjel már használhatja a szerszámát is.”, 213.), vagy a munkás és kalauznő párbeszédében a sörtípusok hajszínekkel való többértelmü felcserélésének obszcenitása, („A feleségem a barnát szereti nézni”, 215.) éles ellentétben állnak mind a szereplő nézőpontjával, mind pedig a narrátori szövegrészek visszafogott, erősen poetizált eroticizmusával. A párhuzamosan futó, egymást kiegészítő szerepviszonyokhoz kapcsolódó történet így értelmezhető az elbeszélői dilemma önreflexív megjelenéseként, ahol a szereplehetőségek a narratíva létrehozását célzó szerzői törekvés irányait is kijelölik. A „,becsukódott” főhős ,a Sörgyár kapuja elött egy férfit pillantott meg, aki megsimogatta egy fiatal nőnek az arcát”, a kibontatlan történettel keltett hiányt „az üres helyre” vele szemben leülő, nyitott aktatáskájú munkás tölti ki. (215216.) [A kiemelések tőlem. B. S.]

A börtönben mint hermetikusan zárt világban leélt évek számának hangsúlyozása, akárcsak az ott eltöltött idő pontos meghatározása nem kizárólag a fogoly-lét szenvedéseinek mennyiségi mértékegységeiként olvasható. („A hét évvel ezelött levetett ruhája...”, „Egy óra múlva a kis fogháziroda felé vitték”, 212.; A folyosón még körülbelül egy óráig ácsorgott”, 213.) A más idő- és térdimenzióban eltelt „hét év” mint a nemi szerepek szeparációja jelenik meg, a testiséget az önfenntartó mechanizmusok szintjére redukáló körülményeket ${ }^{440}$ követően pedig B. a másik nemhez viszonyított öndefiniálás lehetőségeivel szembesül a börtönkaputól a trafikig tartó villamos- és taxi út során. Nem véletlen, hogy ezzel az önmagát a másik, a nő relációjában meghatározó törekvéssel

\footnotetext{
${ }^{438}$ Alekszandr DuGIN: Az erósz lázadása. http://www.tradicio.org/kvintesszencia/trad99dugineros.htm (2008. 04. 20.)

${ }^{439}$ DÉRY Tibor: Szerelem. = UÖ.: Theokitosz Újpesten. (Összegyüjtött novellák II.) Szépirodalmi, Bp., 1975. 216. (A további hivatkozások erre a kötetre utalnak, az oldalszámok a föszövegben az idézetek után, zárójelben találhatók.)

${ }^{440}$ Vö. Michel FouCAULT: Felügyelet és büntetés. (A börtön története.) Ford.: Fázsy Anikó és Csürös Klára. Gondolat, Bp., 1990. 24-25.
} 
összefüggésben, a feleségéről szólva idéződik fel újra a börtönben letöltött idő: „Felülmúlta mindazt, amit a börtönben hét évig összegyüjtött róla. (222.)

Az érzetek és gesztusok testnyelvét beszélő szereplő nonverbális kommunikációja, és az ezt kísérő cselekvések („Nadrágzsebébe nyúlt, de nem volt zsebkendője, mellyel megtörölhette volna a homlokára kicsapott verejtéket”, 214.; ,a szeme könnybe lábad”, 215.; „egyenesen ült, nem támaszkodott hátra, 216.) a külvilág ingereinek befogadására adott közvetlen válaszreakcióként is értelmezhetők, mely kifejezéskészlet alapvető fontosságú a nyelvileg körvonalazódó szubjektumpozíció szempontjából. Ilyen viszontreakció, hogy miután B. meglátta, hogy „Egy cukrászda narancsszín csíkos ponyvája alatt vörhenyes fényben cigarettázott egy fiatal nö” (216.), azonnal ő is erre, cigarettára (és nöre) kezd vágyakozni, ám ahelyett, hogy rágyújtana, a doboz Kossuth apropóján a saját jelenlegi helyzetét, testi és mentális állapotát körülíró beszélgetésbe kezd. Az eközben a taxisoförnek többször feltett „meglátszik rajtam” kérdés, valamint a divatáruüzlet kirakatában végzet vizuális önvizsgálat ezzel összefüggésben irányulhat a szabadulása óta ért hatások, felismerések kiváltotta elváltozásokra is.

A színekben, képekben megelevenedő, megszólaló külvilág eseményeit közvetítő narrátor ugyanakkor a szereplő helyett beszél, szavai azt a hiányt hivatottak betölteni, ami tematikusan a B. önmeghatározását jelentő másik nélkülözésében, szövegszinten pedig ennek az állapotnak a megnevezhetetlenségében jelentkezik. Ezért, illetve a Szerelem szövegét tipográfiailag is széttagoló váltakozó szerzői és szereplői szólamok miatt tűnik leegyszerűsítésnek, hogy „Déry Tibor novellája úgynevezett szerzői elbeszélés, azaz maga az író adja elő a történetet”, amelyben így persze „az író és főszereplő nézőpontja azonban nem válik el egymástól, Déry tulajdonképpen azonosul hősének lelkiállapotával és magatartásával". ${ }^{441}$

Szövegszerüen a főhős szükszavúsága mögött meghúzódó dilemmát, a kiszabadult politikai elitélt tragédiáján túllépő olvasatot éppen az ezeket kontextualizáló elbeszélői szólam, az előadott történthez csak távolról illeszkedő, az ismétlések, motivikus kapcsolatok révén hangsúlyossá váló narráció teszi lehetővé. Az értelmezői tevékenységet helyettesítő, olvasói azonosulást szolgáló stiláris elemek számbavételén és az életrajzi megfeleltetéseken túl, tehát érdemes szem előtt tartani azt a Ricoeur elméletét követő meglátást, miszerint ,a szöveg végső jelöltje egy »sajátosan történelmi jellegü« tudat, amely egy világhoz, egy kultúrához, egy hagyományhoz tartozóként ismeri fel az embert". 442

\footnotetext{
${ }^{441}$ Vö. PoMOGÁTs Béla: Az emberség ereje. i. m. 92.

${ }^{442}$ SzITÁR Katalin: i. m. 62.
} 
A Szerelemben a zöldséges stand elött leparkoló taxiból kinézve „egy hegy piros jonathánalmá"-ra téved B. tekintete, majd sétája során, miközben felötlik benne, hogy a felesége „amúgy sem várja”, egy almafát vesz észre. („Szemben, egy kerítés mögött, egy virágzó almafa állt.” 218.) A fát vizsgálva a virág-méh metaforán keresztül felidéződik a megtermékenyítés folyamata, majd ezzel összefüggésben egy menyasszony (a hajdani feleség légies,) képszerü megjelenítése. Ugyanakkor a Szeptember végén szövegelemeinek újraszituálásával Petőfi idealizált szerelemképét, a modernitás irodalmi hagyományában poétikai viszonyként értelmezi. A kép lezárásában tehát a konkretizáció helyett, a feleség újbóli felemlítését mellőzve, magával a szövegmüködéssel, az olvasott metaforizáció tematizálásával egészül ki a gondolatmenet. „Ha egyenként nézte az ember a virágokat, legbelül, a kehelyben, a felül kerek, alul keskenyedő szirmok tövében egy-egy rózsaszín lehelet ült, mely külön-külön mindegyiknek gyöngéden megszínezte menyasszonyi fényét. Annyi méh dongott a virágokban, egy-egy kis rezgő aranyfonál a szirmok fehér szövetében, hogy az egész fa hullámozni látszott, mint egy szélbe feldobott fátyol.” (218.) [A kiemelések tőlem. B. S.]

A virágok beporzása, vagyis a fizikális kapcsolat a porzó és bibe között egy harmadik fél kapcsolatteremtő tevékenységének eredménye, az „aranyfonál” vagyis a méh, a viszonyrendszer azon tagja, amely a metaforában a hasonlítás relációja, és ekként a hasonlító (tenor) és a hasonlított (vehicle) között teremt kapcsolatot, így létrejön a termés: az alma, illetve a metafora.

A novellában ezután mintegy indoklásként szövegszerüen is megfogalmazódik magának a metaforizációnak az imént említett folyamata, a hasonlítás, ,az érinthetőn át az érinthetetlen” kifejtése. „B. állt, s hallgatta a beszélgető fát. Talált két ágat, melyek között ki lehetett látni az égre, s azon túl még messzebb, egy mozdulatlan gyapjas felhőre, mely úgy hatott, mint elérhetetlen távolságban egy másik virágzó almafa az alsó fa fölött. Addig nézte a kettőt, az érinthetőn át az érinthetetlent, amíg el nem szédült." (218.) [A kiemelések tőlem. B. S.]

A börtön elszigetelt, idötlen világából kiszabadult embernek ez a természetben tett „első” útja éppen a bibliai hagyomány felidézésével válik az önmeghatározás, pontosabban az emberként történő önmeghatározás egyik alapvető gesztusává a novellában. A teremtést követő paradicsomi és bünbeesés-történet utáni létállapot közötti temporális és időszámításbeli különbség felől válik érdekessé a novella két világát elválasztó időbeli differencia, melynek eredményeképpen B. úgy érzékeli a körülötte lévő valóságot, mintha „új világba” került volna (másik híd stb.). 
Mind a paradicsomi, mind pedig B. börtönbeli élete, bár fordított elöjellel, egy olyan öntudatlan, a külvilág történéseit nem érzékelő, zárt létforma, amelyhez képest ismeretlen, más létmódot jelent az emberi időszámítás megjelenése illetve tudatosulása. ${ }^{443}$ B., a magát korábban a világmindenség egyetlen birtokosának vélő isteni teremtmény, sétája során a természet maradandóságának, az évszakok állandóságának tapasztalatán keresztül emberi mivoltával szembesül, és „,megszédül e felismerés súlya alatt”. („Addig nézte a kettőt, az érinthetőn át az érinthetetlent, amíg el nem szédült.”)

Ami azonban mindkét világban (a paradicsomiban és a bünbeesést követő kiüzetés utániban), közös az a Nő, a feleség jelenléte, mely nem véletlenül kap a virág-méh metaforán keresztül egy transzcendens, az „örök értéket” hordozó jelentést. A szerelem mint kezdetektől meglévő emberi érzés, épp a bibliai hagyományra tett, említett utalásrendszeren keresztül kerül egy szélesebb, az emberi létforma változásait (büntetés, börtön) negáló képzetkörbe.

Makk Károly 1970-es Déry-rendezésének, a Szerelemnek ${ }^{444}$ filmtörténeti jelentősége vitathatatlan. Ugyanakkor elsősorban „,megragadó példája annak, hogyan lehet egyéni sorsok kamaradrámájában egy egész korszak történelmi megpróbáltatásait érzékeltetni", ${ }^{445} \mathrm{~s}$ mint ilyen, elsődlegesen a szöveg ideologikus olvasatát támogatja. Igaz, a forgatókönyv megírására eredetileg maga a szerző, Déry Tibor vállalkozott, ${ }^{446}$ elfogadva Makk Károly ötletét, - a Szerelem szövegének összekapcsolását a későbbi Két asszony című elbeszéléssel - végül azonban „a rendező keveset tartott meg Déry eredeti forgatókönyvéből, de megkapta a legfontosabbat: az író hozzájárulását, hogy két novellája anyagából egy film készülhessen". 447

A Szerelem címü film tehát a tekintetben, hogy megismétli, illetve felerősíti a novella példázatos jellegű politikai megközelítését, hatványozottan jelöli az említett problémakört (lásd mottó), ugyanakkor a két Déry-szöveg között megteremtett átjárás

\footnotetext{
${ }^{443}$ Hasonló módon tematizálódik ez a problémakör Albert Camus Közöny címủ regényében a föhős, Meursault tárgyaláskor tanúsított és a börtönben tapasztalható Napfényhez való viszonyában. A szövegben többször is szereplő, kisbetűvel írt „nap” szó, mint az égitest neve és a „nap” mint egy meghatározott időszak, 24 órányi időegység az azonos szóalakokon keresztül összekapcsolódik, egyik szó felidézi a másikat is. Így a „nem szabadulok meg a naptól” kijelentés azt is jelenti, hogy nem szabadulhat az anyja temetésének a napjának emlékétől sem, miként attól az esetleges, Salamanó által is megfogalmazott vádtól vagy önvádtól sem, hogy az anyját öregek otthonába adta. Ezzel összefüggésben éppen a napfény elviselhetetlensége jelenti a gyilkosság elkövetéséhez vezető motivációt is.

${ }^{444}$ Szerelem. Rendezte: Makk Károly, író: Déry Tibor, forgatókönyv: Déry Tibor, dramaturg: Bacsó Péter, operatőr: Tóth János, gyártó: Mafilm 1. Játékfilmstúdió, 1970.

${ }_{445}$ Györffy Miklós: A Liliomfitól az Utolsó kéziratig (Makk Károly és a magyar irodalom) http://www.c3.hu/scripta/metropolis/9903/gyorffy.htm (2006. 04 .20.)

${ }^{446}$ Vö. DÉRY Tibor: Szerelem. Irodalmi forgatókönyv. Filmkultúra, 1967/4. 102-129.

${ }^{447}$ Vö. SzaBó B. István: Déry Tibor és a film. In: „D. T. úr X.-ben” (Tanulmányok és dokumentumok Déry Tiborról.) Szerk.: Botka Ferenc, Petőfi Irodalmi Múzeum, Bp., 1995. 115-126.
} 
révén további szövegjegyekre, intertextuális viszonyokra nyílt rálátás. Hiszen a nyelv metastruktúrája nagyban befolyásolja a filmi metafora értését, sőt ennek müködési és befogadási mechanizmusát is alapvetően meghatározza a „természetes” nyelv képszerüsége és a filmképek közötti hasonlósági viszony összefüggése, vagyis e „két” nyelv egymásra-olvashatóságában jelentkező, rétegzett beszédmód. ${ }^{448}$

Makk Károly filmjében, nyomon követve a képszerüség és a nyelvi kifejezésmód összefüggéseit, elsősorban ennek hiánya, a metaforikusság tüntető némasága szembetűnő. Míg a Déry-szöveg az auditivitás helyére, az elégtelen verbalitás nyomán a vizualitást helyezi, mindenekelőtt a képszerüség, a metaforikusság eszközeivel, addig a filmnyelv a dolgok didaktikus, szimbólum-jellegü bemutatását követi. E különbséget jelezheti a novellában a „megszólaló világ” képeit éppen egy szóképpel érzékeltető narratív kitérő. „...megszólalt körülötte a világ. Olyasféle érzés volt, mint amikor a moziban géphiba miatt egy ideje hang nélkül pergett a film, s egyszerre, egy mondat, egy szó közepén visszatér a hang a színészek üresen tátogó szájába, s a süketnéma terem, melyben mintha a közönség is elvesztette volna harmadik kiterjedését, hirtelen milszekundumos indítással a mennyezetig megtelik hangos zenével, énekkel, párbeszédekkel. Körös-körül minden szín robbanni kezdett." (214.)

A hang nélkül pergő film a hasonlat részeként egyben a befogadás nélküli történés, a környező, nem tudatosult valóság metaforája. A filmképekhez így a novella szövege alapján ugyanúgy elválaszthatatlanul hozzátartozik a „harmadik kiterjedés” - a tér és idő mellett - a hang, miként a megszólaló világ kiváltotta érzésekhez ezek nyelvi kifejeződése, (mely jelen esetben egy szóképen keresztül történik).

Mindez azonban nem jelenti egyszersmind a rögzített jelentések maradéktalan kifejezését, vagyis egyszerü megfeleltetést, hiszen mindig a befogadó értelmezői tevékenységének is függvénye az aktuális jelentés. A novellában ezzel összefüggésben nem egyszerű szimbólumokat találunk, miként a filmben (fekete autó, óra), hanem a szövegszinten megjelenített konkrétum mindig egyben figyelemfelhívó jelzés is arra nézve, hogy a mögöttes, elvont fogalomkör a szöveg hátterében meghúzódó metaforarendszer része. Éppen ezért tartja Déry is elégtelennek a szimbólumokat, és az újabb poétikai törekvésekről szólva ezzel szembe az asszociációt, a képzettársítások metaforikusságot támogató szabadságát állítja. „A szimbólum kényelmes lombsátor, minden elfér alatta. Nap, árnyék, ringatózunk. Megfejtjük vagy félbeszakítjuk, mint egy keresztrejtvényt. [...] A szimbólumot mindig magyarázni kell - az olvasó maga kommentálja -, de a kommentár

${ }^{448}$ Vö. Francesco CASETTI: Filmelméletek 1945-1990. Osiris, Bp., 1998. 59-74. 
s az élmény között oly nagy az ür, hogy azt semmiféle frenezis nem tudja kitölteni. Az új versben nincs szimbólum. Az új versben minden szó önmagát jelenti. Önmagát jelenti vagy asszociációs centrum: mint mágnes felé, ömlenek köré a rokon, komplementer szavak, amik kiegészítik, teljessé teszik...,

Az itt idézett elméleti fejtegetés szóhasználata különösen figyelemre méltó, ha összevetjük a Szerelem fent említett (alma)fa mint érinthető és a felhő által megformált érinthetetlen lenyomat, kép metaforikával, amely összefüggésben a novellabeli fényárnyék, szöveg-test stb. szembeállítással, mintha a fenti elméleti megfontolás poétikai érvényü alkalmazása volna.

A filmben a Szerelem szövegének említett metaforikus, továbbá a bibliai hagyományhoz kötődő emblematikus jelentésrétegéből a hangulatkeltés eszközeként csak elszórt tartalmi elemek jelennek meg. Az első háromnegyed részét kitevő (a Két asszonyt alapul vevő) történet folyamatosságának érdekében az írott szövegnek szinte kizárólag B. (a filmbeli János) szabadulásához kötődő cselekményszála maradt meg. A villamosút során a filmben bevillanó emlékképeket a szabadulás körülményei töltik ki, a megszólaló világ helyére így a lelkileg megtört, szabadulását hinni sem akaró, elkeseredett ember portréja kerül. Szó sincs kacérkodó kalauznőröl, fiatal nőkről az utcán, az átszálláskor ehelyett egy a padon kuporgó öregasszonyt mutat a kamera, és ebbe a kistávol plánba sétál be a filmbeli János, didaktikusan utalva ezáltal a film első részében megjelenő, azóta halott, fiát hazaváró anya alakjára.

A taxiból kiszálló B. parkbeli kalandjából egy háttérfestő, virágzó almafa marad a filmben, mely legfeljebb a kezében lévő, csokor helyett tépett virágos ágakra ad magyarázatot, de a korábban átélt fiziológiai változásokkal járó, megrázó élményére nem. A novella szövegében ugyanis, miután az almafa látványa elbüvölte B.-t, hazaindulása előtt, látszólag indokolatlanul „néhány lépés után egy bokor mögé állt s hányt...” (218.)

Ez a parkrongáló közjáték azonban mint árulkodó megnyilvánulási forma a szövegtesten is maradandó nyomokat hagyott. A szervezet müködésének, a testi mechanizmusok automatizmusának felidézésével a korábban fizikálisan is az ideológia apparátusa által szorongatott lény nyilvánul meg. A testi és spirituális, a fizikális és metafizikai vagy a profán és szent találkozási pontján megszédülő szemlélő egyúttal a nyelvi közvetítettség, a nyelvhasználat ideologikusságával is szembesül. A narratíva által csak részben birtokolható külvilág szereplőjének társtalansága és az elbeszélői

\footnotetext{
${ }^{449}$ DÉRY Tibor: Csicsergés a homokóra körül. = Uő.: Botladozás. (Összegyüjtött cikkek, tanulmányok I.) Szerk.: Réz Pál, Szépirodalmi, Bp., 1978. 329.
} 
tevékenységet, a megfelelő szavak keresésével végző narrátor hiányérzete hasonló jellegű. (Talán nem véletlen, hogy a hány igéböl éppen a hiány szósor megkülönböztető fonémája hiányzik!?)

Az ebből adódó duplikáció fény-árnyék játék módjára textuális rétegzettségként jelenik meg a szövegben, retorikai szinten kapcsolva össze az említett hagyományos oppozíciókat. („Talált két ágat, melyek között ki lehetett látni az égre, s azon túl még messzebb, egy mozdulatlanul álló gyapjas felhőre, mely úgy hatott, mint elérhetetlen távolságban egy másik virágzó almafa az alsó fa fölött. Addig nézte a kettőt, az érinthetőn át az érinthetetlent, míg el nem szédült.” 218.)

$\mathrm{Az}$ embléma- és metaforarendszer elemeként a korábbi szavak, kifejezések referenciális, jelölő funkciója háttérbe szorul (a politikai elítélt szabadulásának története), és a figurálitás nyomán, kifejező módon a szövegvilág részeként értelmeződik (a politikai elítélt szabadulás-történetének elbeszélhetősége). B. végül inkább a Szerelem hőseként, mint politikai elítélt gyanánt indul haza a „keskeny napsütötte mellékutcákon át, melyek virágzó gyümölcsfákkal hintették tele a domboldalt” (218.).

A filmben megjelenő házvezetőnő viszont a kiengedett politikai fogollyal beszélget, nem pedig a feleségét, az egyetlen asszonyt hazaváró férjjel. Ezért sem érzi annyira tragikusnak azokat az apróságokat (társbérlő, közös fürdőszoba, felcseperedett gyerek), amelyeket B. első hallásra alig akar elhinni. Azt, hogy B. az idő múlását másként érzékeli, illetve ahhoz csak lassan képes alkalmazkodni; a lassú kameramozgásokkal dolgozó, ritkán vágott, folyamatos képekkel ugyan sikerül a rendezőnek és az operatőrnek érzékeltetnie, de feleségét hazaváró férj novellabeli várakozását és az ezt kiváltó hiányt távolról sem.

A novella szövegében motivikusan is hosszasan elökészített feleség alakja a találkozáskor már nem csupán a rég nem látott, vágyott nő, egy a sok bebörtönzött férjet haza váró asszony közül, hanem a Nő, a bibliai Évára emlékeztető egyetlen társ. Hiszen az említett metaforizáció során felidéződő bibliai bünbeesés-történetet végeredményeként a paradicsom elvesztésével a férfi jutalma vagy büntetése, de mindenképpen egyetlen társa a nő. A nő, akinek azóta osztályrésze a fájdalmas gyermekszülés és a társát óvó féltés és aggodalom. $^{450}$

A Szerelem említett metaforizált szövegrésze, mindezeket figyelembe véve, olvasható a korábbi, azonos címet viselő Déry-vers önértelmező átirataként, mely az akkor megfogalmazott problémát emeli az elbeszélés egyik poétikai eljárásává. A megfoghatatlan, hiányként jelenlevő valaki utáni vágy leginkább maga a szerelem-érzés

${ }^{450}$ Vö.: Móz 3,14-24. 
nyelvi birtokbavétele, mely ezúttal is egy természeti kép, jelenség retorikai optikájának segítségével fogalmazódik meg:

$$
\text { Szerelem }^{451}
$$

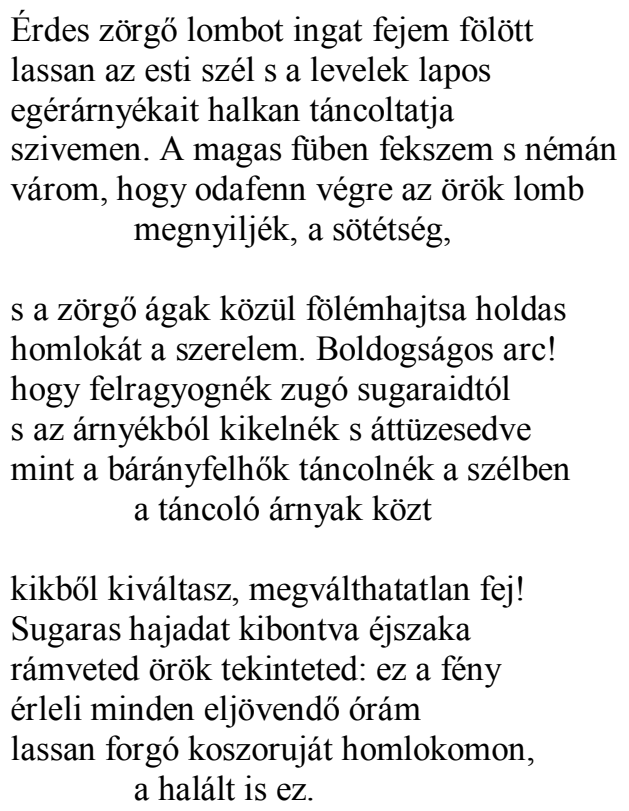

Az (alma)fát idéző „gyapjas felhő” (szó)képe, miként a vers beszélőjét jelölő hasonlatbeli „bárányfelhő” (, s az árnyékból kikelnék s áttüzesedve/ mint a bárányfelhők táncolnék a szélben”), a Szerelem idézett szövegrészének megfelelően olyan köztes, kitüntetett állapot, létforma, amely a maga súlytalan, illékony jellegével a leginkább utal a lent és fent, a sötétség és világosság, a halál és élet közötti verbális kapcsolatot megteremtö szövegszubjektum jellegére. Az „elérhetetlen távolságban egy másik virágzó almafa” légies képe, a „mozdulatlanul álló gyapjas” felhő, akárcsak a hiányként jelenlevő nő, a feleség (aki „levegőnek és húsnak egy különös, soha nem látott vegyülete”), a nyelvi közvetítettség tapasztalatával, a transzcendens jelölt elérhetetlenségével szembesíti az elbeszélőt és olvasót egyaránt. A fény-árnyék viszonyok alakulásából kirajzolódó hazaérkezést elbeszélő történet, és ennek végpontján a birtokolni vágyott feleség is csupán (nyelvi) illúzió, a szavak szerencsés összjátéka, a napfény által megvilágított felhő lenyomata, szókép. Így érthető, hogy a haza illetve a néha harmóniát jelentő nyelv újbóli birtokbavételéhez vezető útra is ez a tapasztalat veti rá árnyékát, a valóság délibábos képe: a „keskeny napsütötte mellékutcákon át, melyek virágzó gyümölcsfákkal hintették tele a domboldalt"(218.).

A novella végén fizikailag megjelenő feleség a metafora- és hagyomány történés részeként egy transzcendens állapot, metafizikai kategória kézzel fogható része „levegőnek

\footnotetext{
${ }^{451}$ Nyugat, 1930. május 16. (XXIII. évf., 10. szám) 783.
} 
és húsnak" vegyülete, szövegszerü matéria és egyszersmind dicsfényü tünemény. A hazaérkező föhős e kettős viszonylatban, a primer érzékszervi tapasztalat és a szövegre vetülő fény-árnyék játékaként érzékeli felesége jelenlétét."(A szoba zöldes sötét volt a kőris lombjától. [...] megismerte a felesége szagát. Leült az ablak mellé, a lélegzett. Nézte a kőris lombját. Egész testével a felesége szagában ült s lélegzett.” 221.; másutt „A kőris világoszöld, fehér szélü levelei között néha-néha egy kis szellö rebbent el, $\mathrm{s}$ megborzongatta a délutáni fényt a cselédszoba fehérre meszelt falain.” 222.)

Ez a fajta kettősség, a nyelv teste és a megtestesülés nyelvisége felöl is olvasható Déry Tibornak a racionális kontra érzelmi logika különbségéről írott teoretikus fejtegetése. Akár a fentebb idézett, ebben az időszakban íródott Szerelem című verset, akár az itt tárgyalt Déry-novellát értelmezve a szóhasználat, a szövegalkotás és a metaforikus, asszociatív beszédmód szempontjából is figyelemre méltók ezek a 20-as évekre datált fejtegetések. „Érzelmi logikáról beszéltem - pontatlan szó, de nem tudok jobbat a képzettársítás funkciójának motorjára -, szemben a racionális logikával, mely a valószínüségek kauzalitására mutat. Az érzelmi logika az öntudat alatt [értsd ennek hatókörén kívül, attól lejjebb levő szinten B. S.], szabályozza a költő képzeteit (melyek ugyancsak az öntudat alól szállnak fel kész szavak vagy szócsoportok formájában, vagy pedig meghatározhatatlanul, még testet keresve: ilyenkor mint hiányérzetek jelentkeznek.)",452

Természetesen mindez szépírói szempontból, a költői szövegalkotás gyakorlatára nézve értendő, ugyanakkor nagyon hasonlít az elbeszélő szövegek kapcsán kifejtett legújabb prózapoétikai elképzelésekre. (Vö. például a fentebb idézett Szitár Katalin szöveggel: „a történet megnevezésére irányuló kísérlet: a (megfelelő) szó keresése”, ahol is „az elbeszélő tevékenységet valamilyen hiány érzete váltja ki”.)

„A szó - írja Déry a szövegalakítást magyarázandó - lehet absztrakció is, lehet nyelvtani hajtószíj, zenei hangemlék, optikai kép, lehet minden racionális értelem nélküli hangcsoport is, meghatározhatatlan képzettársítások gyüjtőmedencéje."453 A felvetés életmüben betöltött fontosságára utal, hogy e téma kapcsán két alkalommal is, kisebb szerkezeti hangsúlyeltolódásokkal szinte szó szerint megismételte elképzelését. ${ }^{454}$

A Szerelem fentebb idézett, a köztes létforma és érzékelési mód metaforikus és emblematikus összekapcsolásában tetten érhető nyelvi megoldásait előlegezi a novella egy

\footnotetext{
${ }^{452}$ DÉRY Tibor: Csicsergés a homokóra körül. = UÖ.: i. m. 330. [A kiemelések tőlem. B. S.] ${ }^{453}$ Ua. 326.

${ }^{454}$ Vö. DÉRY Tibor: Megjegyzések a líra szociológiájához. = Uỏ.: i. m. 314-315. és Uő.: Csicsergés a homokóra körül. = Uö.: i. m. 326, 329.
} 
korábbi, más perspektívájú, az elbeszélő szempontjából előadott narratívája, amely így visszamenőleg válik egyszerü szürreális intermezzóból hangsúlyos szövegszervező motívummá. A megszólaló világ eseményei között mintha az elbeszélés végkifejlete, a hazaérkezett B. köztes érzékelési módjából eredő dilemma kapna hangot, és a „zöld kőris” árnyékában a feleség fényviszonyok általi ábrázolása előlegeződne meg. „Az utca túlsó oldalán két pipacspiros ló vágtatott egy üres társzekér előtt, melynek andalító zörgése megrezegtette az égen úszó tündéri bárányfelhőket. Egy üvegzöld kertecske hullámzott el hátrafelé, két lángoló üveggömbbel, s mögöttük egy nyitott konyhaablakkal.’(214-215.)

Ugyanakkor, ha nem a szereplő tapasztalataiként, hanem az elbeszélői törekvés (,az érinthetőn át az érinthetetlent”) részeként olvassuk az idézett szövegrészt, a bárányfelhő mint a szöveg vallásos hagyományára utaló, Jézus alakjához kötődő embléma egyben a felsőbb szövegalakító szándék, elbeszélői nézőpont metaforájaként ${ }^{455}$ értelmezhető. Ebben a kontextusban az üres társzekér, miként a novella keretéül szolgáló textuális tér, a téma kevésbé hatásvadász, nem idealizált vagy tragizáló előadását veszélyeztető vágta hatására zörejével a légies, képszerü metaforikus kifejezésmód (a „mozdulatlanul álló gyapjas” felhő) megzavarásához vezethet. A korábban a cigarettázó „fiatal nő” látványa is e poétikai prizmán keresztül, a benyomások metaforikus megjelenítésével társul: „a járda sarkán egy kis fiatal gesztenyefa már kilombosodott, egy tenyérnyi ide-odarezgő laza s csillogó árnyékot gyüjtött maga alá” (216.).

A szerelmet egy vallásos hagyomány részeként, a transzcendenciát és a nyelvi megragadhatóság, birtokba vétel esélyeként érintő elbeszélés a végre fizikailag megjelenő feleséget is az említett metaforizáció fényében, a szövegszerveződés eredményének tekinti. „Az ablakon behulló alkonyati fényben megkönnyebbülten látta, hogy az is megöregedett, bár szebb volt, mint a milyennek hét éven át napról napra újra és újra felidézte.” (225.)

A Szerelem névtelen szereplője tehát a nyelvi önmeghatározás során, mind transzcendens, mind textuális viszonyítási pontként, a nőt, feleségét jelöli meg, és úgy veszi B. a novella végén a szájába felesége korábbi szavait („Úgy tudott súgni, hogy az ember a szájába kívánta venni a szavait, minden szavát külön.” 223.), miként az ima szövegét szokás a pap után mormolni, ettől remélve feloldozást és megváltást. Ugyanakkor e szövegrész, felidézve a méh-virág metaforabeli megtermékenyítési aktust, sajátosan árnyalja a feleség azon kérdését, hogy lehet-e még gyerekük, miközben fiuk ,a kertben maradt”, akit B. jóformán látni sem lát meg. Az ezt követő rituális mosdatási jelenet éppen

\footnotetext{
${ }^{455}$ Vö. Szerelem című vers hasonló szöveghelyével („Mint bárányfelhők táncolnék a szélben”) illetve a novella kapcsán a „mozdulatlanul álló gyapjas felhővel” szövegrész értelmezésével.
} 
a metaforarendszerrel való kapcsolata révén a bibliai hagyományból ezúttal a megváltástörténetét idézi. (Az „új” gyermek utáni vággyal összefüggésben felidézhető a taxisofőr B.-nek [a filmben Jánosnak] adott tanácsa, hogy minden nap igyon ,egy fél liter jó bort”, és az a filmbeli jelenet, amikor a kamera nagyközelben mutatja a tányéron fekvő nagy szelet kenyeret, majd a kezében almával ágyon ülő férj elgondolkodó tekintetét.)

A büntelen bűnös történetét az emberiség büneit magán viselő teremtmény vallási hagyományával társítja a szöveg, az előbbit elbeszélő narratívát ez utóbbi emblémáival folyamatosan egybejátszató metaforikájában. Az „égen úszó tündéri bárányfelhőket” említve a novellában vagy az elöszövegnek tekinthető Szerelem-versben az áttüzesedett „bárányfelhők” nemcsak a verbális kifejezésvágy, de a megváltót, a megváltástörténetet felidéző szóképek is. Jézus isten bárányaként lehet egyrészt az embereket büneiktől megszabadító húsvéti bárány, ugyanakkor ismeretes az Apokalipszis diadalmaskodó égi bárányaként is. ${ }^{456}$

A Makk-rendezésben a feleség korábbi kijelentéseit kérdésként megismétlő férj inkább komikusan hat azoknak a metaforikus utalásoknak a hiányában, amelyek a novella szövegében a kiszabaduló fogoly és a feleségéhez hazatérő férj alakját egyaránt érzékeltetni tudták. A könyvbeli kontextusban egész más jelentést kap a férj hazatértén meglepődő házfelügyelőnő többször elismételt Uramisten felkiáltása is, továbbá fontos szerepe van a filmben akkor először megjelenő menübeli almának is. „...a földszinti lakó felsége csöngetett be a lakásba, ugyancsak egy csésze kávéval, vajas kenyérrel, kolbásszal, egy ugyanolyan jonatánalmával, mint amilyet az utcán, a Közért kirakatában látott." (221.) [A kiemelés tőlem. B. S.]

Az „ugyanolyan” szóalakkal hangsúlyozott párhuzam és jonatánalma szókapcsolatban szereplő név említésével ez a szövegrész is tekinthető a bibliai hagyományra tett újabb, jelzésszerü utalásként. A Jonatán név ugyanis többször előfordul a Szent könyvben, ${ }^{457}$ de az értelmezés szempontjából talán fontosabbak az arám tragikumokként számon tartott biblia kommentárok, mely kifejezés a héber szövegek arámi nyelvü fordításainak jelölésére szolgálnak a teológiatörténetben. A babiloni fogságból hazatért zsidók ugyanis, mivel elfelejtették a „szent nyelvet”, és arámiul beszéltek, nem értették meg az istentiszteleteken felolvasott bibliai szövegeket, ezért azokat arámi nyelvre fordították, parafrazálták. Ilyen átírás a Jonatán tragikumaként jegyzett, V. századból való,

\footnotetext{
${ }_{456}$ Vö. VANYÓ László: Katakézis, költészet és ikonográfia a 4. században. Jel., Bp., 1995. 108-111.

${ }^{457}$ Jonatán az Ótestamentumban több személy neve. Ilyen néven szerepel többek között Mózes unokája (Bír 18, 30) és Saul fia, Dávid barátja is (1Sám 18, 1-5).
} 
a prófétai könyvekhez készült szöveg is, amely inkább tekinthető magyarázatnak, mint fordításnak. $^{458}$

E jelentéktelennek tünő pontosításban, az almafajta megnevezésével, a fenti szóalakban szereplő név felidézte bibliai értelmezéstörténet is bekapcsolódik a novella szövegében tematizált metaforarendszerbe, melyben tulajdonképpen éppen a bibliai hagyomány parafrazálását, illetve a szerelem kapcsán történő újraértelmezését kapjuk. A B. mint „babiloni fogságból” hazatérő, a korábbi harmonikus létezésének „,szent nyelvét” feledve, fokozatosan sajátítja el azt a verbális képességet, mely alkalmassá teszi a környező valóság leírására, a személyes tapasztalatok megfogalmazására. A börtönből hazatérő útja metaforikusan ennek az elsajátítási folyamatnak a története, mely során „egy kultúrához, egy hagyományhoz tartozóként”, a természet egyik létezőjeként határozza meg önmagát. A felesége szavait mániákusan ismételgető férj komikusnak tünő cselekedete, a nyelv újraelsajátításának tragikumával, infantilis anakronizmusával társul. A novellazáró párbeszéd megrázó ereje sokkal inkább keresendő ebben a viszonyulásban, mintsem a primer érzelmeket maradéktalanul kifejezni vágyó elkeseredett igyekezetben.

Az ágyon ülő és kezében az almával elgondolkodó férj alakja ekként egy jól beállított, kifejező, mégsem túl hangsúlyos képpé válhatna a filmszövegben, de a novellabeli metaforarendszerből kiszakított alma megjelenítéséből így inkább a két „segítő” által hozott étel milyenségére, és az ebben megnyilvánuló szolidaritás mértékére következtethet a néző. Ezáltal az ártatlanul bünhődő hős alakja sem helyezhető abba az általánosabb jelentéskörbe, amelyről a novellában éppen a fent vázolt és szövegszerüen megjelenő metaforikus rendszert alkotó elemek tanúskodnak.

Makk Károly filmjében a megszólaló világ szavaiból tehát a rendező által meghallott, értelmezett rész válik hangsúlyossá, összefüggésben a másik, Két asszony címü novella alapján megrajzolt társadalmi politikai háttértablóval. Ennek erősítését szolgálják a novellákban nem szereplő „kiegészítések” is, (a Jánostól eltérő döntést hozó, így szabadlábon levő „barát” alakja, Luca egzisztenciális kiszolgáltatottságát érzékeltető iskola-jelenet, vagy a faluról érkező édesanya figurája), melyek, mint az egy korabeli kritikában is olvasható: ,stílusban, hangvételben sőt még fényképezésében is elütnek a film alapszövegétől, sematikusan felvázolt didaktikus ellenpontok csupán”. ${ }^{459}$

A filmcímet adó novellában egymással jól megférő két jelentéskörből e rendezésben a politikai hangsúlyozódik, a másik, nem kevésbé jelentős azonban eltünik,

\footnotetext{
${ }^{458}$ Vö. GeCSE Gusztáv - HorvÁth Henrik: Bibliai kislexikon. Kossuth, Bp., 1984. 24.

${ }^{459}$ FEKETE Éva: Déry-Makk: Szerelem. Kritika, 1971/6. 1-4.
} 
ami az írott szövegek többrétegü jelentésrendszeréhez képest mindenképpen egyszerüsödést eredményezett. A film nagy részét kitevő Két asszony címü novella részletesebb tárgyalása nélkül is megállapítható, hogy a fentebb vázolt metaforizáció és képalkotási mód, a két elbeszélés együttolvasásával ugyanakkor a filmbeli feldolgozás szempontjából is befolyásolja az értelmezést. Nem hagyhatók figyelmen kívül a film olvasatakor például az olyan novellabeli utalások, mint a gágogó libák és az utcán társalgó öregasszonyok többszöri helyettesítéses felidézése, vagy a mama szájából elhangzó példázat a darázs súlya alatt meghajló árvácskáról, és ennek későbbi summás megismétlése a szobában, a mama körül repkedő darazsak említésével. ${ }^{460}$ Ezen utalások alapján pedig a jellemábrázolás gazdagításán túl jóval összetettebb szerep tulajdonítható a filmben is nagyszerüen megjelenő, mama képviselte többnyelvűségnek, és a halál közelében ,újra megtalált" anyanyelvnek, amely szintén a szövegmüködéssel összefüggésben, de más irányba nyitja meg a szöveget. ${ }^{461}$

A filmben a felvillanó emlékképekkel és tárgyakkal váltakozó, dokumentum jellegü (az 50-es évek társadalmi- politikai légkörére utaló) képek is kevésbé tűnnének magyarázó jellegü megfeleltetéseknek, ha nem az egyes szereplökhöz kapcsolódnának. A szimbólumokként müködő képbevágások így azonban magától értetődő viszonyban állnak a jelöltjükkel, és legfeljebb atmoszférateremtő, jellemábrázoló szerepük van. A kameraállások és képbeállítások is ezt látszanak erősíteni. A halállal dacoló, fiát hazaváró, makacs, ágyhoz kötött öregasszony például rendszeresen olyan nagyközel plánban ábrázolódik, melynek egyik részét kitölti az ágy melletti virágcsokor, így kapcsolva egyértelmüen össze a kettőt.

Egyértelműen listázhatók a film asszociatív képsorainak a mama és Luca tudatában megjelenő, a múlthoz vagy az emlék- és vágyképekhez kapcsolódó részletei, szemben például a novella szövegével, melyben a metaforarendszeren belül egymással kapcsolatban álló elemek nem magyarázó, hanem jelentésbővítő szerepet kapnak. Ez az egyértelmü megfeleltetési viszony tehát kevésbé illeszkedik ahhoz a metaforikus képalkotás logikája alapján értelmezhető viszonyrendszerhez, melyben a szereplők állnak. A novella szövegében meghúzódó általánosabb jelentésréteg és az ehhez kapcsolódó müfaji hagyomány (példázat, mese) helyére így egyszerü szimbólumok kerülnek. (Óra = idő múlása, öregedés; régi szép ruhák, kalapok = fiatalkor, nosztalgia stb.)

A nyelv és a filmnyelv müködésének belátásait figyelembe vevő, vagy éppen ezt a

\footnotetext{
${ }^{460}$ DÉRY Tibor: Két asszony. i.m. 261., 262., 271-272.

${ }^{461}$ Vö. KoszToláNYi Dezső: Az orosz és Ottlik Géza Drugeth-legenda címü írásaival.
} 
témát felvető alkotások nem köthetők korhoz, és nem is új keletủek, függetlenül attól, hogy az ezeket „leíró” elméleti munkák gyakran valóban későbbi fejlemények. A 70-es évek magyar filmművészetében is található olyan alkotás, mely minden „külső körülmény” ellenére részleteiben egy más típusú képalkotási eljárásról tanúskodik, mely nem hogy nem járul hozzá a szöveg jelentésbeli összetettségéhez, inkább újabb értelmezési szempontokkal gazdagítja. Ilyen rendezés például Fábri Zoltán Hangyaboly címü filmje, melynek alapjául szintén egy irodalmi mü, Kaffka Margit azonos című kisregénye szolgált. ${ }^{462}$

Az újabb filmelméleti munkákban már kiindulópontként szerepel a filmnyelv és a nyelv egymásra vonatkoztathatósága, a verbális nyelv figurativitásának hatása a képnyelvre. Bíró Yvette például összefoglaló filmelméleti könyvében a bevezető részben tárgyalja a beszéd és a film formanyelvének egymásra vonatkoztathatóságát, ez utóbbinak a konkrétsága és komplexitása szempontjából. ${ }^{463}$ Persze a tudatos rendezői megoldásoktól függetlenül az értelmezés során a befogadó számos olyan momentumnak is jelentést tulajdoníthat, amely a szövegben nem kódolt, de annak összetettsége, a nyelvi müködéssel paralel szerkezete lehetővé teszi (amennyiben ennek nyomai megtalálhatók a filmben).

Így válik a Makk-rendezés által összedolgozott két novella szövegének intertextuális viszonylatában amúgy is összekapcsolódó, emblematikus név kitüntetett jelentőségűvé az értelmezésben. A Két asszonyban a mama legszemélyesebb tárgyaihoz ugyanúgy hozzátartozott az állandóan Kossuth adóra hangolt rádió, mint a német nyelvü könyvek. A magyar szabadságharcnak és kibontakozó politikai életnek ez a rádió által is közvetített emblematikus figurája és említése azért válik hangsúlyossá, mert a haldokló, fiát hazaváró anya abban a tudatban hal meg, hogy fia filmrendezői munkásságáért Kossuth-díjat fog kapni. Mindezzel összefüggésben a két szöveg filmbeli kapcsolata nyomán is kitüntetetté válik, hogy a Szerelemben kiszabaduló politikai fogoly a taxisofőrt arra kéri, álljanak meg egy trafiknál, mert egy doboz Kossuthot szeretne. A soför maga megy el a cigarettáért, pénzt sem kérve „Jánostól”, aki az autóban ülve így végül megkapja

\footnotetext{
${ }^{462}$ Jurij Lotman, aki $A$ retorika címủ munkájában éppen a nyelv metaforikus müködését tárgyalva idézi példaként a Hangyaboly egyik részletét. ,....míg a filmi metafora egyik tagját rendszerint minden erőfeszítés nélkül megfogalmazhatjuk (mi több, tudatosan arra irányul, hogy elmesélhető legyen) addig a másik az ilyen szavakba öntésnek ellenáll. [...] Fábri Zoltán, magyar rendező Hangyaboly címü filmjének középpontjában rendkívül bonyolult és többsíkú dráma áll, amely egy magyar apácakolostorban játszódik a $\mathrm{XX}$. század elején. Az események bonyolult metaforikus viszonyba lépnek a templom barokk berendezésének bizonyos részeivel, melyeket premier plánban vettek fel. Ezek közül különösen kitünik egy reliefszerű medalion, amely a magvetőt ábrázolja. A metafora ezen tagját úgy lehet megfejteni, ha közvetlenül lefordítjuk a magvetőről szóló evangéliumi példázat verbális szövegére (Máté, 13:3-8, Lukács 8:4-8, Márk, 4:2-8). A metafora második tagját nem lehet szavakkal elmesélni, de az elsőhöz (és más hozzá hasonlókhoz) viszonyítva feltárhatjuk az értelmét." Vö. JURIJ Lotman: A retorika. In: Helikon, 1999./ 1-2. 93.

${ }^{463}$ Bíró Yvette: A hetedik müvészet. Osiris. Bp., 1998. 18-22.
} 
a Kossuth-ját, a Kossuth-díjat e sajátos, politikai felhangoktól nem mentes formában. A tulajdonnév által felidézett emblematikus történelmi személyiség, és hozzá kapcsolódva a magyar szabadság és függetlenség képzete hagyománytörténetileg újraértelmeződik. („Kossuth Lajos azt üzente....”) Ezt az olvasatot erősíti, az a már említett látszólagos ellentmondás, hogy a főhős megkapva Kossuth-ját, nem gyújt azonnal rá, inkább a név apropóján saját helyzetét, állapotát értelmezi.

(Ez az öniróniának tekinthető gesztus sem elsősorban Déry Tibor életrajza felől magyarázható, hisz az 1948-ban a Kossuth-díját átvevő író a Szerelem írásakor még nem sejthette 1957-es letartóztatását. Az már a sors iróniája, hogy az 1949-ben a Rajk-perrel kapcsolatban letartóztatott Szász Béla bebörtönzésének és kiszabadulásának a novella alapját adó története később megismétlődik Déryvel.)

A romantikus szerelem és szabadságvágy („Szabadság, szerelem/ e kettő kell nekem”) összebékíthetetlenségének tragikuma inkább ezek megragadhatatlanságának, nyelvi birtokolhatatlanságnak iróniájával társul a Szerelem címü elbeszélésben, így a kinyilatkoztató, váteszi attitüd is az irodalmi hagyomány részeként kérdőjeleződik meg („Szabadság, szerelem/ E2 kell nekem”) a textuális működésmódot, a megszövegezés poétikai dilemmáit téve az elbeszélés egyik tárgyává. ${ }^{464}$

A Szerelem című novella itt vázolt megközelítése talán azért is indokolt, mert mind Déry helyenként kifejtett alkotói elképzelésével, mind pedig az életmüben elszórtan jelentkező poétikai megoldásokkal párhuzamba állítható. Megkockáztatható tehát, hogy Déry Tibornak az ideologikus sematikussággal szemben az irónia és az elbeszéltség müveleteire reflektáló regényeivel párhuzamosan íródott novellái, kisregényei e tekintetben kapcsolódhatnak a nagyepikai szövegszervező eljárásokhoz. A Szerelemben fellelhető, a 80-as évek prózairodalmát előlegező metaforikus szövegalakítási formák, prózapoétikai megoldások felől talán a kései Déry-elbeszélések is értelmezhetők egy a politikumot mellőző textuális megközelítés segítségével. Az életmü avantgárd irányultsága, a szürrealista, expresszionista kezdeti tájékozódás hatása, a szövegmüködés, az asszociatív metaforikus nyelvhasználat vonalán fedezhető fel nyomaiban. A hagyományos narratív móduszokat negáló, a koherens, metonimikusan szerveződő

\footnotetext{
${ }^{464}$ Petőfi Sándor $A$ szerelem országa címü versét, vagy Vörösmarty Mihály esetében a magánéleti és közéleti szerepvállalás összeegyeztethetetlensége, a kettő közötti folyamatos ellentétet tekintve a fenti problémakör megjelenése a magyar irodalomban is egy korábbi, a 19 századi irodalomban is hangsúlyos jelenségnek tünik. Az említett Petőfi-vers pedig elbeszélő jellegével, a szerelem témájának korántsem „romantikus”, idealázált megjelenítésével nemcsak az életmüben kirívó darab, de az éden, paradicsom metaforikája, az én és természet szembeállító megjelenítése sokkal inkább értelmezhető a Déry-szöveg megoldásaival összefüggésben.
} 
történetmondást fellazító szürreális képzettársításokat müködtető beékelődés egyúttal az „intertextualitás rétegződését vonja maga után”. 465

A kései Déry-szövegek elsősorban a groteszkbe hajló irónia, az önreflexív kétely müködtetésével éppen az intertextuális és emblematikus szövegszervezés irányába mozdulnak, mégis figyelembe véve az életműben végigvonuló metaforikusság és a trópusként értett szó poétikai jellemzőit, ${ }^{466}$ belátható Bori Imre megállapítása, hogy Mészöly Miklós vagy az induló Esterházy Péter mellett „,a Déry-regények rajzolták ki a magyar próza új és modern csapásainak nyomvonalait". 467

\footnotetext{
${ }^{465}$ Vö. Thомка Beáta: Déry Tibor Országúton címü regényének szürrealista elemei. In: A magyar irodalmi avantgardról. A magyar nyelv, irodalom és hungarológiai kutatások intézete, (Értekezések monográfiák 10.), Újvidék, 1985. 97-101.

${ }^{466}$ Ezzel kapcsolatban lásd például: KeMÉNY Gábor: Átutazóban a nagyepika felé. (Nyelvi képek, motívumok szövegszervezö funkciója Déry Tibor Pesti felhöjátékában.) In: Szerk.: BotKA Ferenc: Mérlegen egy életmü. (Déry Tibor halálának huszonötödik évfordulóján rendezett tudományos konferencia előadásai.) Petőfi Irodalmi Múzeum, Bp., 2003. 38-47.; vagy EGRI Péter: A befejezetlen mondat kezdőképéről. In: Ua. 48-55.

${ }^{467}$ Vö. BORI Imre: Déry Tibor kisregényeiröl. = Uö.: Prózatörténeti tanulmányok. Forum - Akadémiai, Újvidék - Bp., 1993. 225-242.
} 


\title{
2. „Írni, mintha mondanám. Hogy olvassa mintha hallaná.” - regényes önéletírás és/vagy az önéletírás regénye? (Závada Pál: Milota)
}

\author{
„hysteria $=$ méh \\ nyalánk fullánk méz \\ a méh begyüjti a mézet \\ a dolgozó méh fullánkja \\ az elszáradt női nemiszerv" \\ József Attila ${ }^{468}$
}

Závada Pál Milota című regényében, ${ }^{469}$ a nőfaló méhész Milotának egyik csábítási eszköze az éneklés, a ,jeles méhecské”-ről szóló udvarló versikéje pedig többször révbe juttatja. Roszkos Erka megható, szuggesztív, a testfelületeket feltáró, önmagát élve boncolgató monológjait viszont mintha a Szabad-ötletek jegyzékének ambivalens nőszerepe ihlette volna.

A nyelvben és egymásban létezés ontológiai illetve szexuálesztétikai dilemmái a Milotában többféleképpen tematizálódnak. Ebben az olvasatban a regény két talán legmeghatározóbb vetülete: az élő szó(beliség), a vokalitás, vagyis a nyelv akusztikai elemeinek kitüntetett szerepe, valamint a méhek, méhészet bioszemiotikai, illetve müvelődéstörténeti megközelítéséből kibontakozó metaforikus réteg.

A Jadviga párnájában megtestesült szöveg, a napló párnakönyv jellegü, közvetlen érinthetőségének kézzelfoghatósága a testiség nyelvtől sem független vetületének csak az egyik tapasztalata. A test megosztottsága nyomán ott a Másik „egyfelől puha, langyos, kellően lágy, bársonyos, félszegnek látszó teste, másfelől pedig a hangja - a hang, mindig a hang -, mely zengő, jól formált, nagyvilági, stb.",470

A Milota rezonanciaterében ez hang, a szerelmi beszéd interferenciális hullámhosszán terjedve már inkább akusztikai kifinomultságot feltételez. A Jadviga párnájának „test-könyve” a könyvtestben átadja helyét a szövegvilág disszonáns akusztikai terének, melyet elsődlegesen a többszólamúságról, a regény figurális elemeiről, tropológiai megkomponáltságáról gondoskodó szerelmi beszéd alakzatai, illetve ennek retorikai (hang)jegyei határoznak meg.

A két Závada-regény, a Jadviga párnája és a Milota közös szövegjegyeik alapján olyan következetes szerzői eljárás részeredményeinek tekinthetők, melynek közép-

\footnotetext{
468 JÓZSEF Attila: Szabad-ötletek jegyzéke. Antlantisz, Bp., 1990. 32.

469 ZÁvadA Pál: Milota. Magvető, Bp., 2002. (A regény szövegére a továbbiakban az idézett részek után zárójelben az oldalszám feltüntetésével hivatkozom. B. S.)

${ }^{470}$ Roland BARTHES: Beszédtöredékek a szerelemröl, i. m. 93.
} 
pontjában a személyes irodalom müfajainak keretében (napló, memoár, önéletírás) a többnyelvüség különböző regisztereit, a szociális makroközösségek, társadalmi rétegek dokumentális szövegeit és a populáris zenei, színházi kultúra ,irodalmon kívüli” alkotásait egyaránt nyelvi produktumokként kezelő regénypoétikai törekvés kidolgozása áll.

Ebben a poétikai irányultságában pedig komoly szerepet kapnak a regény nyelvi, metaforikus szerveződései, nem pusztán a szereplők szóhasználatának illetve az elbeszélésmód stiláris megformálásnak szintjén. Vagyis a szöveg „nemcsak azért metaforikus, mert sok metafora van benne" - figyelmeztet Olasz Sándor, a Jadviga Párnájáról szólva, hanem sokkal inkább mert ,a regényben metaforikus szerkezetek alakulnak ki". ${ }^{471}$

A Jadviga párnája mint a talált kéziratot, létező naplókönyvet imitáló regény (a „valódi szerzők” nevének feltüntetésével) nem számolt a referenciális olvasat veszélyeivel, $^{472}$ a Milotában pedig már senki sem számíthat a valósághüség igazságtartalmára, a „valódi naplóíró” lelepleződik: a színdarab szereplői nem elevenedhetnek meg, a darab szövegkönyvben marad. Mégis a két Závada-regényt (túl a megszólalásig hasonló könyvformátum kiadói marketingfogásán) egyaránt jellemzi az önéletíráshoz közel álló müfajokkal, a memoárral, naplóval és az életrajzi regénnyel való szoros kapcsolatuk. A személyes irodalom említett formáiról, miként a Milotáról is elmondható az a törekvés, hogy „semmiféle elbeszélés ne legyen lehetséges egy elbeszélő »én« nélkül” és, hogy „minden történet csak egyes szám első személyben létezik” ahogyan azt Angyalosi Gergely kritikájában megfogalmazta. ${ }^{473}$

Philippe Lejenue önéletírói paktumának értelmében persze nem önéletírás a Milota, leginkább pedig nem Závada Pál önéletírása, a legalapvetőbb lejenue-i követelménynek, a szerző és elbeszélő azonosságának - akárcsak a Jadviga párnája esetében - ezúttal sem tesz eleget a szöveg. Ugyanakkor két szabályos önéletírásnak, illetve -mondásnak lehetünk szemtanúi, az azonban, hogy a fültanúság elmarad - nem a saját előadásában halljuk az öreg Milota testamentumát - már szorosan összefügg a „valódi szerző” könyvbeli szótlanságával. Ugyanakkor a szerző, aki nem egyszerü személy, „hanem egy író és

\footnotetext{
${ }^{471}$ OLASZ Sándor: Között. (A családregény metamorfózisai az újabb magyar irodalomban.) Forrás, 2001/10. 112.

${ }^{472}$ Lásd Grecsó Krisztián Pletykaanyu című könyve körüli médiavisszhangot, melynek középpontjában a szereplök beazonosíthatósága, a referencialitás akár peres úton bizonyítandó megléte állt, $\mathrm{s}$ ezt némiképp megelőlegezte vagy lehetővé tette a Jadviga párnájának szociografikus és dokumentatív jellege, illetve a Lehoczky-család „magánlevelzésének” forrásként való felhasználása.

${ }^{473}$ ANGyalosi Gergely: A nagyszabás szétbomlása. (Závada Pál: Milota.) = Uỏ.: Romtalanítás. (Kritikák, esszék, tanulmányok.) Kijárat, Bp., 2004. 163.
} 
publikáló személy, összekötő szál szövegen kívül és szöveg között”, ${ }^{474}$ korábban felolvasóestek, író-olvasó találkozók alkalmával gyakran kölcsönözte hangját szereplöinek, és ha valaki hallotta már előadásában például valamelyik Milota-szónoklatot, (amelyeket előszeretettel olvasott fel) az nehezen tudja úgy kézbe venni a Milotát, hogy ne ez az ismerős hang elevenedjen meg.

Závada Pál második regénye, mely „egy 67 éves férfi és egy 34 éves nő egymást faggató, egymásban tükröződő testamentuma”, az elbeszélő(k) és szereplő(k) azonosításával, illetve a kizárólagos egyes szám első személyü előadásmód alkalmazásával leginkább az önéletírás müfaji és poétikai megoldásait követi, miközben ennek elsődleges dilemmájával a fikció és referencialitás, a költött-valós, hamis-igaz oppozíciójával szembesíti önmagát és olvasóját. ${ }^{475}$ A szerzői narráció látszólagos hiányának és a személyes elbeszélői szólam(ok)ra épülő beszédmódnak a kettőségében tehát egy olyan tudatos regénypoétika elképzelés fedezhető fel, amely az önéletrajz hagyományos műfaji követelményrendszerét bontja meg, illetve értelmezi, és amely így nem írható le a befutott szerző (ál)szerény gesztusának megnyilvánulásaként. A Jadviga párnája sikerét kísérő „,ezt a könyvet nem én írtam, hanem három naplóbejegyző” Závada-passzust ${ }^{476}$ visszhangozó $^{4}$ „ők az elbeszélők nem én” szerzői kijelentés a Milotát olvasva árulkodóbb, semhogy elfogadható magyarázata lehessen a 168 órában Sándor Zsuzsannának adott válasz: „talán mert még mindig nem érzem elég jó írónak magamat ahhoz, hogy a saját hangomon is megszólaljak". 477

A saját hang kitartó keresésének narratológiai összetevői: az adott szerephez tartozó szólam, a személyiségjegyeket megképző nyelvhasználat vagy az originális megszólalás elérhetetlensége a szerző és az elbeszélő-szereplők szempontjából is egyaránt meghatározó, mintegy létkérdés. A nyelvben létezés ontológiai dilemmái a Milotában többféleképpen tematizálódnak, a legtöbb esetben inkább a történettel harmonizálva, esetenként mégis teoretikus hangzatossággal párosulva. („Ámbár én azt mondom, ide figyeljetek, idézzen bárki akármilyen pontosan is bármit, hivatkozását úgyis elferdíti az az

\footnotetext{
${ }^{474}$ Philippe LejenuE: Az önéletírói paktum. Ford.: Varga Róbert. Fosszília, 2002 /1-4. 140. Lásd még: = UÖ.: Önéletírás, élettörténet, napló. (Válogatott tanulmányok.) Ford., vál.: Z. Varga Zoltán. L’Harmattan, Bp., 2003. 17- 46.

${ }^{475}$ Vö. Dobos István: Az én színrevitele. (Önéletírás a XX. századi magyar irodalomban.) Balassi, Bp., 2005. Különösen: 5-20.

${ }^{476}$ (,Ezt a könyvet nem én írtam, hanem három naplóbejegyző írta. A regény szerzősége az ugye a fikciós játék miatt vonódik itt kétségbe. Három naplóbejegyző van [...] Misóé mindig a kurzív és az alcím az, hogy Napló, de kurzívval szedve, azt is Miso írta oda. Mert, hogy szerintem Miso téved, mert ez egy regény, de ő azt írta, hogy nem.”) Vö. Móra Irodalmi Estek: Parti Nagy Lajos és Závada Pál beszélgetése. Elhangzott Szegeden, a Móra kollégiumban 1998. április 22-én.

${ }^{477}$ Az iró ne tévesszen szerepet. Sándor Zsuzsanna Závada Pállal készített interjúja, 168 óra, 2002. május 16.
} 
értelmezés, amibe ezt az idézetet önkényesen belefoglalja, hogy ezzel alátámassza az igazát. Így aztán minek legyek én szó szerint visszakereső és lábjegyzetelő filológus, [...]. Olvastam és dumáltam egész életemben, de most az idő már fogytán, úgyhogy csak dumálok.” 25.)

A könyv harmadik fejezetét kitöltő Ház a piactéren regényesített, elbeszélt színdarabjának egésze - miként Roszkos Erzsébet (szöveg)identitás keresése („elnézem szövegem alanyát, aki most szórendek közt botorkál és szinonimákat fontolgat jobb híján, míg szerepemet játssza” 15.) - mindamellett, hogy az „emberi természet és emlékezet fikcionáló hajlamáról, a szerepjáték kényszeréről s nem utolsó sorban az író fikcionált és »valóságos« énjének alkotói dilemmájáról szól,” a regény szövegéből kihallható szerzői, illetőleg a regényben megszólalás (én)elbeszélői problémáival egyidejüleg szembesíti az olvasót. ${ }^{478}$ A szereplők elbeszélői tépelődései összecsengenek a szerző reflektált műhelygondjaival. Milota György zárójeles, szlovák nyelvből, „a gyengébbek kedvéért” fordított részletei a Jadviga párnájának lábjegyzetelő „közreadói” gesztusára emlékeztetnek (38.), másutt a magát a referencialitását is aláásva a fikció mellett foglal állást („Amiben pedig lehetetlen valóságosan kiigazodni, azt, ha csak hozzányúlok, még inkább összegabalyítom magam is, na de tudom én jól, hogy fabulálok." 163.). Roszkos Erka pedig (szép)írói figyelemmel olvassa (újra) saját szövegeit: „De Milotának is, magának is lyukat beszélt a hasába, nem szólva Anciról - [...] - akinek Kohut éppen csak beköszönt a könyvtárba, s a kicsike máris az ujja köré volt tekerve, és mind rágták a fülemet, míg be nem adtam a derekam. (Has, ujj, fül, derék mondat ez, ahogy újraolvasom.)" (77.)

A regény említett két legmeghatározóbb és legizgalmasabb vetülete (a szóbeliség, a beszéltnyelvi fordulatok, vagyis a nyelv akusztikai elemeinek kitüntetett szerepe, illetve a méhek, méhészet bioszemiotikai, és müvelődéstörténeti megközelítéséből kibontakozó metaforikus, metanyelvi réteg) az önéletírás müfaji jellemzőivel érintkezve mint a Milota széttartó nyelvi szintjei közötti állandó szövegjellemző, nem korlátozódik egyik vagy másik elbeszélői szólamra, nem rendelődik kitüntetett történetegységekhez: a könyv egészét meghatározza; a foucaulti szerző-funkció jelenlétéről árulkodva. ${ }^{479}$

A hangadás az írott szó alternatívájaként, a személytelen narrációt életre keltő én-ek éneke gyanánt az elbeszélő(k) gyakori szövegbeli dalra fakadásában jut kifejezésre. A társaságban Milota Gyurka viszi a prímet, s daloláskor válik igazán elevenné, mely

\footnotetext{
${ }^{478}$ SzÁvai Dorottya: Mézes-mákos testamentum. (Závada Pál: Milota.) Kortárs, 2002/12. 87.

${ }^{479}$ Vö. Michel FouCAULT: Mi a szerzö? = Uö.: Nyelv a végtelenhez. Latin Betük, Debrecen, 2000. 119-147.
} 
életformáját, létmódját csak elmondja, reprezentálja az ezeket felidéző - a fikció szerint kazettákra mondott, élőszóbeli, hallható; a regényben azonban Erkáéhoz hasonlóan olvasott - szövegrészeiben. E tekintetben csak a dallammal rendelkezö, a címe vagy szövege által felidézett, jelölt és jelöletlen dalszövegek „szólalnak meg”, „hallhatóak” a Milotát olvasva, kinek-kinek zenei müveltségéhez és vájtfülüségéhez mérten. A Cigánybáró kapcsán például Johann Strauss operettjének zenéjével egyidejűleg Jókai Mór Szaffi címü novellája is felidéződhet.

Az éneklés mind a Milota-figura számára, mind e karakter szerzői hitelesítése szempontjából a legadekvátabb önkifejezési formának tünik, mely szorosan összefügg minden más identitásjeggyel. Ezért különösen figyelemreméltó Bányai Jánosnak, a többnyelvű dalok és a nemzeti identitás kapcsolatára tett utalása. ${ }^{480}$ Ahogyan például Garaczi László novellisztikája tekintetében lényeges annak az underground, alternatív zenei és művészeti életnek az ismerete, amelyben szövegei kontextualizálódnak, a Milota értelmezését is befolyásolja eme látszólag jelentéktelen felhangja.

Az írott szövegben megvalósíthatatlan atemporalitás, dallam és szöveg összetett viszonya (,a dallam nem változtat szövegén” József Attila-sort problematizálva), a hangnak e nyelvi idő-, befogadás- és értelmezésbeli medializáltságával ellentétes élményszerü közvetlensége mint vágyott elbeszélői alternatíva, a Závada-könyv muzikalitásában csendül fel. Nem csupán az említett módon tematizálva, de a regénynek helyenként ritmikus prózához, prózavershez közelítő zeneiségében, az élőszóra, hangos felolvasásra szabott mondathatáraiban, központozásában is, (mely tekinthető akár szerzői intenciónak, ha valaki már egyszer hallott Milota-beszédet Závada Pál előadásában).

Erka önelemző, erősen poetikus nagymonológjai is hasonló funkciót töltenek be, mint a Milota szájába adott dalszövegek és ezek olvasásakor felidéződő dallamok illetve kontextusaik. Ebben a megközelítésben igazán hangsúlyos a női elbeszélő szövegrészében egy helyütt említett onanizálás, mely akár poétikai eljárásnak is tekinthető, hiszen eme öngerjesztésnek a csúcspontján egy „valódi”, testi élvezetet (is) nyújtó zene(szer)szám áll, összefonódva ezáltal hang és befogadás, hangadás és élvezet. „Időpocsékolás, hangulatsüllyedés, bele a mocsárba megint, plusz a szégyenérzet. Félbehagyott önsimogatás, egy ótvaros régi sláger végének akarattalan megkönnyezése a negyedik deci után. Aztán a képernyőn valami hegedüversenyt játszott egy frakkos férfi, meredten néztem az ujjbegyeit, a reszkető kezét. Az utolsó kortyokra és akkordokra sikerült leutánoznom a mozdulatait, s mintha torokhangra váltó sóhajom rántott volna magával,

${ }^{480}$ BÁNYAI János: A nyelv-és identitásváltás szomorúsága. Holmi, 2002/11. 1502. 
élveztem végre." (15.) [A kiemelés tőlem. B. S.]

Theodor W. Adorno a zene és nyelv kapcsolatáról szólva jegyzi meg, hogy a „zenei fogalmak identitását sajátos természetük, egzisztenciájuk biztosította, nem pedig az, amit jelöltek”. Az operettek, kuplédalok és „ótvaros régi slágerek” szövegbeli felidézéséből a zene nyelviségének és a nyelv zeneiségének kettőségében megszólaló nyelvfilozófiai probléma is kihallatszik. A Milota regénypoétikai összetevőiröl is sokat elárul az, amit Adorno Alban Berg operái kapcsán megállapít: „zenéje ugyanis minden pillanatban azért engedelmeskedik a szöveg intencióinak, hogy az összefüggés megszervezésével újra elszakadjon azoktól". ${ }^{481}$

A férfi és női szólam kettősége a regényben sem áll össze vegyes karrá, repertoárjában csupa kánonokkal. A két széttartó hang a diszharmóniát, az összhangzat ellehetetlenülését harsogja. A „zengjük a dalt üde mámoros ajkkal” - karénekes, kollektív magabiztossága összhangban a regény politikai, társadalomkritikai szólamával nem csak ideológiailag, de megszólalásmód tekintetében is idejétmúltnak tủnik. A Milota azon regénypoétikai eljárása, melyben az egymás mellett futó szereplői szólamok néhol összekapcsolódnak, másutt elválnak, önállósulnak vagy összecsengenek, megközelíthető a zenére jellemző kompozíciós jegyként, ami nem kizárólag a történetbonyolítás szempontjából érdekes. Závada regénye mondhatni zenés mủ (dramma per musica), mely az operettek, vígoperák tematizált darabjai mellett ezek strukturális, müfaji jegyeit is alkalmazza. Ahogyan például az operában találkozik a zenei eszköztár a színpadi szöveggel, úgy egészülnek ki a regény hagyományos textuális elemei a szóbeliség vokalitásával. A regény diszharmonikus, ambivalens prózapoétikai megoldásai pedig összecsengenek az operának dráma és zene feszültségére épülő jellegével. Ezt a homofóniát és polifóniát váltogató, dinamikus szövegeljárást, mint az érthetőséget és befogadást biztosító ideális narratív harmóniát gátló tényezőt a könyv több kritikusa, különösen Dérczy Péter, a Milota egyik hibájának tekinti. A regény általa említett terméketlen feszültségei, ellentmondásai: az összetett „,megkonstruált” regényszerkezethez viszonyított egyszerü elbeszélésmód és nézőpont alkalmazásában, a nagyelbeszélések klasszikus formai kereteinek lebontásában ugyanakkor ezek müfaji mintáinak követésében, az Erka és Milota képviselte elbeszélői szólam nyelvi erőteljességének különbözőségében vagy ,a szöveg a krimitörvények alapján történő szervezettsége” kapcsán említett linearitás és köralakzat ellentmondásosságában nyilvánulnak meg. ${ }^{482}$ Ugyanakkor mindezek

\footnotetext{
${ }^{481}$ Theodor W. ADORNO: Töredék a zenéröl és a nyelvröl. Ford.: Csobó Péter. Alföld, 2000/11. 87.

${ }^{482}$ DÉrCZY Péter: Az Adamec-villa titka. ÉS, 2002. július 19. 25.
} 
megközelíthetők úgy is, mint az említett zenei müfajok strukturális jegyeire való tudatos és igencsak produktív poétikai rájátszás.

Stanley Fish jól ismert befogadáselméleti megállapítása (nincs szó szerinti jelentés csak leggyakrabban használt kontextus) és a példaként ott szereplő „,az orgona kivirágzik”mondat, (melyben szerinte ugyanúgy hozzáférhető az orgona hangszerként, mint a növényként történő értelmezése), ,igen, ha a müvet jól játsszák, az orgona valósággal kivirágzik" kontextusban értelmezve a Milota történeteinek variációs burjánzása, vagy polifonikussága szempontjából is beszédes. ${ }^{483}$

A szövegkörnyezettől független nyelvhasználat kivitelezhetetlensége a regényben a szerzőjével azonos hangnemü elbeszélői szólam, mely - miként azt Bányai János említett írásában nagyon pontosan megfogalmazza - leírható a „minden idézet” önreflexív felhanggal. Mindez azonban azzal a narratológiai jellemzővel együtt, hogy „a beszéd és az írás ideje, valamint az idéző és értelmezése (az olvasás és átírás) ideje nem esik egybe"484 túl a regény időviszonyain -, a töredékesség és variabilitás teoretikus összetevői felől válik érdekessé.

Az elbeszélök temporális és logikai szempontból széttördelt szövegei, vagy a férfi nő viszonyra épülö, „a szó valamennyi értelmében vett egymásba hatolás lehetetlenségeként” megfogalmazott észrevételéhez kapcsolódó Szávai Dorottya-megállapítás: „a töredék kitüntetettsége, a szerelem, a nyelv, a lét töredékként való tapasztalása-megjelenítése", 485 és akár Angyalosi Gergely olvasói tapasztalata (,,a gondos és agyafúrt építmény széthull alkotóelemeire" $)^{486}$ egyaránt a regény ezen kitüntetett prózapoétikai eljárását hangsúlyozza. Befogadáselméleti aspektusból olyan sajátsága ez a Milotának, amelynek részeként értelmezhető a regény referencialitást érintő, nyelvkritikai problémafelvetése is. Ha minden tény, tapasztalat stb. már mindig is valamikor, valaki által megfogalmazott, nyelvileg közvetített, realitási alapját vesztett, értelmezést igénylő szöveg, akkor a valóságról tett bármilyen szöveges észrevétel csak variáció, a korábbi verbális entitás felidézése, (ön)idézete lehet. „A valóság - ha mai mesém egyáltalán közelebb áll hozzá, mint a tegnapi - valahogy mindig szürkébb és kiábrándítóbb az elképzelt históriánál.” (196.)

Miként tehát a zene leírható téma és variációja kettősségére épülő struktúraként, a Milota mint zenés mü, történet-töredékeinek sokaságával, a szövegvariánsok

\footnotetext{
${ }^{483}$ Stanley FISH: Van szöveg ezen az órán? In: ODORICS Ferenc (szerk.): Testes Könyv I. Ictus és JATE, Irodalomelméleti Csoport, Szeged, 1996. 265-282.

${ }^{484}$ BÁNYAI János: A nyelv- és identitásváltás szomorúsága. Holmi, 2002/11. 1502.

${ }^{485}$ SzÁvaI János: i. m. 88.

${ }^{486}$ ANGYALOSI Gergely: i. m. 168.
} 
létrehozásával szintén zene és nyelv - Adorno kapcsán említett - elméleti összefüggéseire figyelmeztet. A valóság maradéktalan leírhatósága helyébe kerülő szövegvariánsok és a nyomukban kialakuló hang- és zürzavaros állapot tematizálása tehát, a regény zenei utalásaival társulva, a závadai regénykoncepció szerves részét képezik. A teremtés mint originális alkotás, az egyedi és önálló produktum létrehozása (akárcsak Hajnóczy Péter prózája a „Nagy Fazekas” teljesítményének meghaladhatatlanságával szembesülve) mint létkérdés, a szövegben létezés alapfeltételeként értékelődik fel. A nyelv által, nyelvileg létesített ontológiai státusz (ön)teremtő gesztusa a regény szerzői pozíciójának némasága felől eleve illuzórikusnak tünik. Az elbeszélők addig léteznek, míg beszélnek, mások létfeltétele az általuk való megidézés és elnémulásuk is egyenlő a fizikai megsemmisüléssel, mindez mint seherezádéi állapot „,a Milota mesélőinek narratív ideája: az utolsó lehelettel megszakadó beszédfolyam." ${ }^{487}$ Az önálló, egyedi létrehívásának nyelvi kudarca, Erka (verbális) meddősége - ő sem teremt, csak idéz - tematikusan a gyermekszülésre való képtelenséggel társul, a szó általi (isteni) teremtés szövege(l)léssé degradálódik. (Lásd a regény pünkösdhöz és annak nyelvi aspektusaihoz kapcsolódó bibliai vetületét.)

A Jadviga párnájában megtestesült szöveg, a napló párnakönyv jellegü, közvetlen érinthetőségének, kézzelfoghatóságának helyébe a Milotában az akusztikai kifinomultság, auditív elsődlegesség került; könyvtestből, szövegtér az olvasás termékeny erotikájából, a hangzás meddő élvezete lett. A szöveg örömét ebben a tonális rendszerben elsődlegesen azok a retorikai (hang)jegyek határozzák meg, amelyek hagyományos értelemben a szöveg élőbeszédszerüségéről, szónoki fogásairól, más tekintetben a többszólamúságról; a regény figurális elemeiről, tropológiai megkomponáltságáról gondoskodnak.

A testi, ,szerelmi beszéd alakzatai”488 a szövegbeli méh-méz metaforarendszer részeként a regény összhangzatát elsődlegesen meghatározzák. Jurij Lotman az ilyen típusú metaforikus működésmódot (melyben „a nyelvi értelmi mező különálló, önmagukban zárt terekre hullik szét, melyek között hasonlósági viszony áll fenn.”) szintén egy orgona-példával illusztrálja: „az ilyen rendszert egy hangszer - írja -, például az orgona regisztereihez lehet hasonlítani. Egy ilyen hangszeren ugyanaz a dallam különböző regiszterekben játszható. [...] Az azonos hangok összehasonlítása a különböző regiszterekben egyrészt felfedi azt, ami közös bennük, másrészt pedig megmutatja,

\footnotetext{
${ }^{487}$ ANGYALOSI Gergely: i. m. 164.

${ }^{488}$ BÁNYAI János: i. m. 1502.
} 
egyenként melyik regiszterhez tartoznak."489 A méh, méz szavak mint a regény motívumrendszerének alapelemei egyszerü szimbólumként olvasva elvesztik a szövegkörnyezetben kibontakozó, e regényt meghatározó, metaforikus jegyeiket, puszta díszítőelemmé, szónoki fogássá válnak. A lotmani megközelítést tekintve azonban a szöveg említett variációs, töredék kompozicionális (zenei) jegyei a hasonlóság retorikai müveletének részeként, a méh-méz metaforákkal összefüggésben értelmezhetőek. A Milota egyes szöveghelyein - miként a zenei téma variációi - vissza-visszatérő méhek hagyományosan egyrészt Káma szerelemisten íjának húrjára tűzve, Erósz, Ámor és Cupidó rovarjaként elsősorban androgün jellegü termékenységszimbólum - akárcsak a regény másik gyakran előforduló motívuma, a mák. Az ehhez a terméshez tapadó méz pedig a férfierő, a szerelmi, testi gyönyörűség kifejezője, másrészt pedig a zsidó-keresztény, valamint az egyiptomi kultúrkörben a születés, halál és feltámadás, a testből kiszálló lélek, illetve a méz az isteni, teremtett világ tökéletességének szimbóluma. A szövegkörnyezettől független jelképiségükben a méh, méz szavak leginkább tematikusan kapcsolódnak a történetbe, ám nem csupán ,szimbólum értékü, hogy Milota éppen a méhészet tudományára tanítja, s ezzel a kifosztott, erős Thanatosz-ösztönű nő figyelmét a teljesség, a halhatatlanság és az újjászületés lehetőségére próbálja irányítani”, ${ }^{490}$ miként az sem, hogy Erka többször „mákvirágnak” nevezi az öreg Milotát (pl. 21.), kontextualizálva ezzel a mák jelképiségét, bekapcsolva a virág-méh-méz (nyelvi) sorba.

Ha valóban igaz, hogy „a nyelvhez való viszony egyre inkább az elbeszélés tárgyává válik", 491 akkor jelen kell lennie ezen hagyományos, közkeletű szimbolika hátterében is annak a nyelvi, poétikai dallamnak, amely (esetleg mégiscsak befolyásolva szövegét) talán azt is magyarázza, hogy például Szávai Dorottya kritikájában, a Závadaregényről szólva, miért folyamodik a legnagyobb természetességgel zenei kifejezésekhez (is) („szövegegysége ritmusában”, „női szólam, férfi szólam”, „kánondallamként felelgetve”) közelítve metanyelvében a regény említett muzikális nyelvi jellegéhez..

A méh-méz szimbolika, kevésbé közkeletü megközelítésében - mely az antik retorikára vezethető vissza - a méh az ékesszólás, a költészet rovarja, miként a méz (amellyel a görög-római hagyomány szerint a méhek töltötték meg a filozófusok száját) a szónoki képesség, a bölcsesség jelölője. Závada regényének az a rétege, ahol leginkább megidéződik az egyidejűsége, közvetlenség és (zenei) nyelv elevensége, az éppen a szöveg

\footnotetext{
489 Jurij LoTMAN: A retorika. Helikon, 1999./ 1-2. 93.

490 SZÁvai János: i. m. 90.

${ }^{491}$ ANGYALOSI Gergely: i. m. 167.
} 
retorikája, melyben a méh-méz metaforikában egyazon kontextusban, egyszerre aktiválódnak az említett szimbolikus jelentések, megtermékenyítve, feltámasztva és megszólaltatva a nyelvet. Seneca az imitáció fogalmát magyarázva folyamodik az apis (méh) hasonlathoz, amelyet később Petrarca az írásmódra nézve is követendőnek tart. „...nekünk is a méheket kell utánoznunk, és mindazt, amit különféle olvasmányainkból összehordtunk, el kell választanunk [...], azután saját szorgalmunk és tehetségünk hozzáadásával a jelzett áldozati nedveket egyetlen ízzé kell egybeolvasztanunk" ${ }^{\text {"492 }}$ - a Závada féle recept szerint ,jó mézes-mákossá”. (700.)

A könyvnek ez a legtöbb kritikusa által kifogásolt nyelvi rétege, elsősorban nem allegorikusan, mondjuk a tótok letelepedése és a méhek kaptárépítése közti egyszerü magyarázatként, vagy a méhészkedés irodalmi toposzával összefüggésben az öregkor szimbólumaként olvasható, és elsődlegesen nem is kizárólag szerkezetileg tagolja a regényt; ${ }^{493}$ a méhészkedés kultúrtörténeti, szakmai fejtegetései többféleképpen érthetők. Ez a nagy terjedelmü, de korántsem szövegidegen rétege a regénynek - a könyv említett alapproblémáit érintve - arra is figyelmeztet, hogy miként bármely megszólalásnak létezik nyelvi előzménye, amely idézetté, variációvá teszi azt, a méhészetnek, a méz felhasználásának is vannak korábbi szöveges nyomai, így ezek megidézésével, szövegkörnyezetük felelevenítésével a méhészkedés történetéről előadott betétek kontextusba helyezik, narratívájuk közegében is értelmezik a regény metaforikus elemeit. Fordítva pedig az elbeszélő magabiztosságát megalapozó, nagymennyiségű méhészeti szöveg idézhetősége teszi a vinyicai méhest szövegtérré, a narratíva létesülési közegévé, a méheket pedig kizárólagos hallgatósággá, azonos módon kezelve a róluk olvasott, felidézett és a velük kapcsolatban illetve általuk előadott történetet. Szilágyi Zsófia írásában azért (is) tartja a regénynek ezt a szimbolikáját nem elsősorban az elbeszélőszereplőkhöz rendelhető, őket jellemző, jelképes értelmű rétegnek, sokkal inkább „csak az olvasó számára feltáruló" jelképrendszernek. ${ }^{494}$

Így egyvalami mégis termékenynek bizonyult Roszkos Erzsébettel kapcsolatban, ez pedig a ,zsongó-lengő méhecskefüggönyök” mint a saját fikciója mögött, ${ }^{495}$ kuncogó

\footnotetext{
${ }^{492}$ Vö. BÁN Imre: Az imitatio mint a reneszánsz arisztotelizmus esztétikai kategóriája. Filológiai közlöny, 1975/4. 374-386.

${ }^{493}$ Lásd Angyalosi Gergely ezzel kapcsolatos megállapítását: UÖ.: i. m. 167.

494 SzILÁGYi Zsófia: Méhraj, galamb alakban. Bárka, 2002/6. 115-120.

495 Vö. Jorge Luis Borges: Al-mu 'Taszin nyomában címü elbeszélésével. Lásd még ezzel kapcsolatban Csányi Erzsébetnek Tolnai Rovarháza kapcsán mondottakkal „ez az áttételesség a szimbolizáló beszéd jelképfüggönyét jelenti, a kódok szöttesébe burkolózást, mert csak ez idézheti meg a világ rejtelmes, szépséges, mély összefüggéseit." CsÁNYI Erzsébet: Világirodalmi kontúr. (Esszék, tanulmányok.) Forum Iskolakultúra, Újvidék - Pécs, 2000. 96.
} 
Milotának szánt átka: ,hogy rogyna rá ez esetben a Maga kárörvendő ábrázatára az a fullánkos firhang!” (28.) [A kiemelés tőlem B. S.]

A méhészet bioszemiotikai vetületével egybehangzó szerzői eljárás, az élőbeszédszerüség, párbeszédesség imitációja ellenére egy olyan időben és térben nem megvalósítható együttes jelen-lét („Minek szólongat, ebből a süket hangszórójából, ha engem némaságra ítél, [...] ilyesmiket ordítozok némán” 34.); amely nagyban hasonlít a méhek egyirányú, monologikus kommunikációjához. Ismeretes, hogy a méhek kétféle mozgáskombinációval, körtáncukkal és csóváló táncukkal képesek pontos információt adni társaiknak a virágpor lelőhely irányára és távolságára vonatkozóan. Jelbeszédük referencialitását tekintve ikonikus (leképzi természeti környezetét), mely szemantikai jegy az emberi beszédben leginkább a hangszimbolikában figyelhető meg. A méh-tánc evolúciós vizsgálata azt is megmutatta, hogy a méhek különböző populációja, fajaiktól és szükebb élőhelyüktől függően módosítva, esetenként rövid hangimpulzusokkal kiegészítve használja nyelvüket, létrehozva annak variánsait. ${ }^{496}$

A Milota itt tárgyalt poétikai jellemzői sokban követni látszanak a méh-nyelv valóságra vonatkoztatottságát, jelölő és jelölt közvetlenségét, mely egy helyütt a méhészet kapcsán (18.), a beszéd és eleven tapasztalat alternatívájaként fogalmazódik meg, mely utóbbiért „loholjál eztán hanyatt-homlok a te méhecskéd után” (19.)

A Fish-példabeli orgonához hasonlóan a 'rovar' illetve 'belsőszerv' jelentésü méh szó azonos alakúságában rejlő kontaminatív többletjelentést, akárcsak a József Attilától idézett mottó, a regény többnyire egyszerre müködteti. Különösen látványos ez a retorikai megoldás Roszkos Erka egyik vallomásában, ahol is egy Milota-történetet idézve önmagát „álanyaméh”-nek titulálja, amiben egyszerre, egyidejűleg ad hangot meddőségének (álanyaméh), az örökletes anyai méhrák miatti halálfélelmének, valamint vizionált anya szerepének (álanya-méh) (185.), máskor meg „könnyezve, mint egy virágpor allergiás” (277.) hallgatja Milota szóáradatát. Az első szexuális tapasztalatainak felelevenítésekor, pedig az ifjú Milotának címzett monológjában szereplő méhész, egyaránt a rovarok és a nők megszállottja. („Apád hangja szól a szobában, hogy ez a kitelepülő gazda, aki vagyok, mondja, pedig elzártam már, legyen egyúttal méhész is.” 214.) Az öreg Milota udvarlóversében nemi jelképisége mellett pedig egyértelmüen összefonódik a méh említett kettősége: „»ezen matériát hordozza méhében az anyaméh“”(305.), vagy amikor a felesége, Mariska -, akinek korábban „combjának az érzékenyebb belső felébe szúrta bele

${ }^{496}$ Vö. KENESEI István (szerk.): A nyelv és a nyelvek. Akadémiai, Bp., 1995. 24-26. 
egy méhecske a fullánkját” (64.) - meddőségét taglalva, ,az öntudatlanul bezárkózik előlem a méhe?” - kérdésre negyvenkét év után méhei „halk döngése közben” keres választ (342.).

Milota „szószéki áriáiban” gyakran megcsendül a méhészet, a mézzel foglalatosság múzsai jellege néhol az etnikai, nemzeti identitás kontextusában, ezek a megjegyzések pedig könnyen áttehetőek az irodalmi hagyomány és alkotás közegébe (,,...a hazai méhészelődeink sem azonosak a mi elődeink méhészeivel”, 79.), ahol a szólás képességét, és annak nyelvi elemeit, akárcsak a vinyicai méhest öregapjától (134.), (méhész-író) elődeitől örökölte. Nem véletlen, hogy Milota felismerését, miszerint „nekem a pofámat szerkesztette meg legjobban a Jóisten, és nem a jobb csuklómat, amelyik, esküszöm, hogy effektív be is görcsöl, mihelyt nekifognék ír... a tollal szántani”, éppen egy író előd, Mikszáth példájával támasztja alá. (13-14.) A virágzó meggyfái alatt, a méhek társaságában mesélö Milota, miként rovarjai, maga is szóvirágok között, az irodalom mint „szóvirágos elvi sík” (187.) tájékán mozog, méh módjára gyüjtögetve és összehordva történeteit, melyek hasonlítanak „azon méhkaptárakhoz, ahol minden méhecske hord, épít, ragaszt” (196.). Pünkösdre készül, a természet akácvirágba borulásának napjára, melynek nagy bibliai narratívája az elbeszélhetőség, a méz-méh metaforikában megidézett (szövegbeli) megelevenedés ünnepeként is értelmezhető. ${ }^{497}$

A méhészetet és annak irodalmát az irodalomtörténethez hasonló, vagy esetenként azzal érintkező „mézes történelem” (60.) formájában elbeszélő Milota mint „nyugalmazott anyagbeszerző, ám aktív méhész” (193.) a méheiről vesz példát. „Amint ők virágrólvirágra szállva, több mézet gyüjtetnek, mint a mennyire maguknak és gyermekeiknek szükségük van, keressük mi is valóságról valóságra haladva, mindazt, ami táplálékul szolgálhat ennek a megfoghatatlan lángnak..." ${ }^{498}$ Maurice Maeterlinck $A$ méhek életéröl írva az ideális ember mellett a jó elbeszélőt is jellemzi, megidézve egyúttal a bibliai történetet, melyben a Szentlélek tüz formájában - méhként!? vö. galamb alakú méhraj (375.) - leszállt az apostolokra és megadta nekik a nyelve(ke)n szólás képességét.

Milota méhei az irodalom, a retorika rovarjai, az elbeszéléseket kísérő jótékony zsongásuk a retorikai gépezet müködésének, a regény zeneiségét felhangoló szöveg zaja. Milota pedig anyagbeszerző (adatgyüjtő, jegyzetelő elbeszélő), ám egyszersmind (a retorika rovarjait istápoló) aktív méhész (szerző).

\footnotetext{
${ }^{497}$ Ehhez hasonló módon kapcsolódik össze a keresztény hagyomány egy rétege - a bünbeesés és a megváltó születésének története - a virág-méh metaforikával és a metaforizáció folyamatának tematizálásával Déry Tibor Szerelem címü novellájában. Lásd: a disszertáció Déry fejezetét.

${ }^{498}$ Vö. Maurice MAETERLINCK: A méhek élete. Ford.: Binder Jenő. Franklin, Bp., 1912
} 
A Milota, a példányszám-adatokból leszűrhető népszerüségét, persze nem a fentieknek köszönheti, a kortárs irodalomba való besorolását azonban az itt említett jellemzői mindenképpen meghatározzák. Azon túl, hogy olvasó azonosulhat Roszkos Erka megható, szuggesztív monológjaival és/vagy jót derülhet az öreg Milota Gyurka szimpatikus anekdotáin, azt azonban, csak ha nagyon igyekszik, akkor képes elfelejteni, hogy (szép)irodalmi müvet, egy újabb „,nagyregényt” olvas, amelynek Závada Pál a szerzője.

Természetesen - miként a Milotát is szerkesztő Parti Nagy Lajos „habszódiája”, $A$ test angyala - Závada Pál e regénye szakmai, irodalomelméleti értékelhetőségén túl egyszersmind olyan olvasásszociológiai jelenség is, amely legalább annyira jellemzi a kortárs olvasóközönséget, mint amennyire meghatározó a mai magyar irodalom szempontjából. „Ha tehát az önéletírás valami szövegen kívüli dolog által definiálódik, az nem a szövegen innen, egy valódi személlyel való bizonytalan hasonlóságból, hanem a túloldalon, az általa előidézett olvasástípusból adódik, az általa kiváltott hitből”- fogalmaz Philippe Lejenue idézett írásában. ${ }^{499}$

„Igazság szerint” tehát nem Milota György vagy Roszkos Erka és semmi esetre sem Závada Pál önéletírása a Milota. Ami mégis vallomásszerü és közös a regény elbeszélöi szólamaiban (miként Závada Pál és Milota György azon kedvtelésében, hogy szívesen énekelnek baráti körben régi, népszerü dalokat, operett slágereket), az magának az irodalmi (zeneművészeti) hagyományának a jelenléte, mely elsődlegesen a literális (auditív) emlékezet, az írható nyelv története szempontjából beszédes, hiszen ,a zene története (mint gyakorlat, nem mint "müvészet«) éppen párhuzamosan fut a Szöveg történetével". 500 Amire nem képes Milota, az elbeszélő (,nem tudom, de nem is akarom én ezt kinek-kinek a fülére külön ráhangszerelni” 300.), azt megteszi a Milota szerzője. Egyazon szövegkönyv részeként pedig egyszerre hallható ki a partitúrából a Szabad-ötletek jegyzékének ambivalens nőképe és a Milotában, illetve a Csárdáskirálynőben tematizált kérdésfelvetés: „Te rongyos élet, bolondos élet, mitől tudsz olyan édes lenni, mint a méz?”.

A Závada-regényeket „összevonó” kritikai visszhang túllépve az első két könyv egymást feltételező és kiegészítő értelmezésén, már nem e tematikusan a férfi-nő viszonyrendszer részeként „folytatásosnak tünő regény” jellemzőit hangsúlyozza. Jadviga Párnájában Ondrisnak a fényképész barátot munkára biztató önreflexív szólamában, (,Az

\footnotetext{
${ }^{499}$ Philippe LEJENUE: i. m. 158.

${ }^{500}$ Vö. Roland BARTHES: A mütöl a szöveg felé. = Uö.: A szöveg öröme. (Ford.: Babarczy Eszter.) Osiris, Bp., 1996. 18.
} 
jár a fejemben, hogy elfut az idö, és annyira nyom nélkül múlik el minden, ami már megtörtént...”) - miként az Olasz Sándor megjegyzi -,,már ott a következő regényt is elölegező feladat: írni kell és mindent lefényképezni”. 501

Ugyanakkor prózapoétikai megoldásait tekintve - ahogyan az Osztroluczky Sarolta Jadviga párnája-elemzése alapján megállapítható - Závada ezen szövegei olvashatók úgy is mint ,poétikailag artikulált szövegek”, melyek alapvetően diszkurzív szerveződésűek, ${ }^{502}$ ekként pedig „,a szavakból mint megnevezésekből, metaforákból épül ki”. ${ }^{503}$

Kérdéses persze, hogy A Jadviga párnáját és a Milotát nem csak időben követő Závada-könyv, A fényképész utókora mint a trilógia harmadik darabjaként megnevezett regény, amellett hogy az „érzékek és érzelmek iskolája”-ként továbbviszi az őt megelőző kötetek tematikáját, mennyiben követi az első két könyv poétikai eljárása szempontjából meghatározó metaforikus történetalakítást.

${ }^{501}$ OLASZ Sándor: Között, i. m. 111.

${ }^{502}$ A diszkurzív poétika fogalmával összefüggésben: „a diszkurzíva nem a szöveg elemeinek, nem is struktúrájuknak, nem is kifejezésének, hanem képzésének, - a nyelvi elemek beszédegységgé alakításának, illetve a szövegfolyamatnak mint »működésben levő nyelvnek « a jelölésére szolgál.” Vö. KovÁcs Árpád: A költöi beszédmód diszkurzív elmélete. In: KovÁcs Árpád - NAGY István (szerk.): A szótól a szövegig és tovább... (Tanulmányok az orosz irodalom és költészettan köréböl.) Argumentum, Bp., 1999. 47.

${ }^{503}$ OszTroluczky Sarolta: Név és metafora Závada Pál Jadviga párnája címü regényében. In: HoRváth Kornélia - SzITÁR Katalin (szerk.): Szó - elbeszélés - metafora. (Müelemzések a XX. századi magyar próza köréböl.) Kijárat, Bp., 2003. 446. 


\title{
3. „Szótestkupac” - (test)építés és (papír)hajtogatás (Zalán Tibor Papírvárosai)
}

\author{
„Nincs rá szó, \\ Nincs neve, \\ De van, aki tud \\ Mit kezdeni vele ... \\ Megalázó, durva szerelem, \\ Ez így elég jó nekem, \\ Megalázó, durva szerelem, \\ Én nem akartam azt, hogy jó \\ legyen!" \\ Menyhárt Jenő, Európa Kiadóo ${ }^{504}$
}

„Papírmadár tollászkodik a papírváros tornyán” - olvasható az 1989-es Borús reggeli üzenetek című Zalán-kötet egyik versében, ${ }^{505} \mathrm{ez}$ az áthallás pedig, arra a rezonancia-térre is rést nyit, amelyben a Zalán-korpusz a szerzö Papírvárosainak falai között visszhangzik tovább. ${ }^{506}$ Ahogyan azt H. Nagy Péter kismonográfiájában a regény „címéhez társítható életmübeli szövegek” közül fentebb idézett verssel összefüggésben megfogalmazza: „a Papírváros fokozottan ráirányítja a figyelmet az életmü lezáratlanságára, a szövegek párbeszédének folyamatára, ily módon a vele való foglalkozás mindenképpen indokoltnak látszik". 507

Az említett kötet $A$ Kis Fehér Kápolnába címü versének lírai alanya az „ott voltam és éreztem hogy máskor voltam ott" felismerés jegyében, ${ }^{508}$ például a Papirváros II. mosókonyhájába helyeződik, az ehhez kapcsolódó regényrészlet pedig olvasható a vers epikus kibővítéseként: „szavakat sodor a sötét”. A szekrény tetejéről felmeredő székek a versben, mint „,az idő hőkölő paripái fenn”, a regény narrátori, egyes szám harmadik személyü szólamában a Delacroix-képeken ,ágaskodó lovak”-ként jelennek meg. (II. 137.), a lány naplójában pedig már a törlés-jel alá helyezett „kis fehér kápolna” említésével idéződnek. (II. 164.) A férfi-szereplő, az építész viszont „,némán tátogott, miközben a szavakat kereste, ez egy kis fehér... kis fehér... [...] kis fehér kápolna”, majd a Néva partján, Leningrádban álló lovakra asszociál, de „lehet - mondja -, hogy az apokalipszis lovai készülődnek a maga szekrényének a tetején, és lehet, hogy ezek itt nem is

\footnotetext{
${ }^{504}$ Lásd: az Európa Kiadó zenekar Megalázó, durva szerelem című számának, Menyhárt Jenő által írt dalszövegét.

505 ZaLÁN Tibor: Az Arkánum Költőinek, Titokban. = Uö.: Borús reggeli üzenetek. (Válságlíra.) Szépirodalmi, Bp., 1989. 35-36.

506 ZaLÁn Tibor: Papírváros (egy lassúdad regény, egy - kimerülve). Kortárs, Bp., 1998., illetve Uö.: Papírváros kettö (Eltévedve). Kortárs, Bp., 2002. A könyvekből vett idézeteket a továbbiakban a föszövegben a kötet és az oldalszám feltüntetésével jelölöm.

507 H. NAGY Péter: Orfeusz feldarabolva. (Zalán Tibor költészete és az avantgárd hagyomány.) Ráció, Budapest, 2003. 11., 156.

${ }^{508}$ ZALÁN Tibor: A Kis Fehér Kápolnába. = UÖ.: Borús reggeli üzenetek. i. m. 28.
} 
szekrények, hanem ajtók, és ha kinyitnánk ezeket az ajtókat, az egyik mögött a végtelen hömpölyögne, a másik mögött a tenger, én ebben a kápolnában most meggyónok és megáldozom, maga lesz az én papnőm, a maga teste lesz az én ostyám, a maga nyála lesz az én borom". (II. 163-164.)

$\mathrm{Az}$ itt tematizált ajtó lehet az a rés, átjáró, mely egyúttal a Papírvárost szervező poétikai eljárás felületi jegyeként és metaforájaként betekintést enged a regény szövegterébe, szorosan összefonódva a textust átjáró testiséggel, a szexussal. A történet szintjén lezajló beszükülés, elzárkózás és leépülés mellett e rés, repedés nyomvonalán szövegszinten olyan területekre nyílik rálátás, melyek éppen az értelmezés nyitottságát, a szövegalakítás befejezetlenségét hangsúlyozzák. Mindezekkel összefüggésben nemcsak az életmü különböző münemű és műfajú darabjai reflektálnak egymásra, hanem például a Zalán-költészet bizonyos jellemzői is más kontextusba kerülnek, átértelmeződnek, esetenként ironikus felhangokkal gazdagodnak. A zaláni „válságlíra” egyes neoromantikus, a szó poétikájára épülő elemei, nyelvi formulái például epikai közegbe helyeződve átértékelődnek, elvesztik azokat a versbeszéd részeként dominánsnak tűnő pozíciójukat, amelyek korábban leginkább egy tágabb költészet- és kultúrtörténeti kontextusba helyezve árnyalódtak. ${ }^{509}$

Míg a versekben „résnyire / nyílt ajtók mögött / gazdátlan sírás lengedez”, ${ }^{510}$ addig a Halvérfesték címü drámában minderre a kiür(es)ítés egyik módozataként az exkrementum olvasódik rá. „GALAMBOS az én lányom nem szarik / PÉTER akkor nyílván félre értettem, ürít / GALAMBOS nyitott ajtónál / PÉTER nyitott ajtónál / GALAMBOS és mennyire nyitott az ajtó / PÉTER résnyire / GALAMBOS az nem nyitott. Az majdnem csukott. Azt is mondhatnánk, szinte csukott / csukottságközeli.",511

A csukottságközeliség szintén olyan határhelyzetet, (tö)rést jelöl, mely nézőponttól függően a kívül és belül, a test és lélek, valós és fiktív oppozíciók; a „kimerítés, illetve a bekebelezés poétikájának" metszéspontjában helyezhető el. ${ }^{512}$ Így érthető, hogy a kialakuló szemantikai kontextusban ,a dialógusok szervezőelve egyre kevésbé a drámai szituáció, és egyre inkább a költői szöveg müködési elve”, ahol is a rés egyaránt lehet (test)nyílás és a szöveg(test) felületi repedése. „GALAMBOS de én résen voltam. nem volt esélye. résen / PÉTER ennek a családnak mániája a rés / LINDA amíg el nem vettél neked is mániád volt a

\footnotetext{
${ }^{509}$ Ezzel kapcsolatban részletesen lásd: BORDÁs Sándor: Versviszonyok - szöveg(belsö)terek [ZALÁN Tibor: Lassú halált játszik], Bárka, 2000/6, 119-127.)

${ }^{510}$ Vö. ZALÁN Tibor: Elmozdítás. = Uö.: Lassú halált játszik. Ister, Bp., 2000. 20.

${ }^{511}$ ZALÁN Tibor: Halvérfesték. = Uö.: Azután megdöglünk. (Kilenc drámai szöveg.) Napkút, Bp., 2004. 219.

${ }^{512}$ VILCSEK Béla: A kimerités és bekebelezés esztétikája. ZALÁN Tibor: Lassú halált játszik; Hal, vér, festék; Papírváros I-II. http://www.kortarsonline.hu/0104/ VILCSEK.HTM) (2005. 08. 10.)
} 
résem / FODOR mondtam, fiam, hogy mindig légy a résén” - valóban, „mintha e dialógus hősei nem a szereplők, de még csak nem is a beszéd tárgya, a WC, a hal vagy Linda női rése lennének, hanem MAGA A RÉS SZÓ."513 Az ebben a darabban is tetten érhető áthallások, szövegszerü átvételek nyilvánvalóvá teszik, hogy „a Papírváros II. olyan narratív eljárásokkal bővíti előzményének repertoárját, melyek újabb perspektívákat rendelnek hozzá a történetszálak tematikus bonyolításához". 514

Így például a Halvérfestékben olvasható disznóölés-leírás tipográfiailag elkülönülő betétként olvasható a Papírváros II. részében (II. 158-160.), továbbá a drámadialógusokként formált regényrészletek is erősítik a különböző müfajú szövegek együtt- és egymásra olvashatóságát. (pl. FIATAL LÁNY, FÉRFI dialógusa II. 140-148.) Az tehát, hogy a szerteágazó életmű más-más megnyilatkozási módjai az alkotói törekvés tekintetében párhuzamba állíthatók egymással, csak részben aposztrofálható, ,a hiteles formáért vívott” gigászi küzdelemként. ${ }^{515} \mathrm{~A}$ korpusz alapvető poétikai irányultságai például nem magyarázhatók kizárólag azzal filológiai és alkotáslélektani egybeeséssel, hogy a regény egyes részei párhuzamosan íródtak a velük közel egy időben megjelenő verseskötetekkel, színpadi szövegekkel. (Papírváros I. - Fénykorlátozás, Papírváros II. - Lassú halált játszik.) A regény felvet ugyanis néhány minden eddiginél markánsabban jelentkező törekvést, melyek alaposabb vizsgálata visszamenőleg is újraértelmezheti, átrendezheti a szerző korábbi szövegeit, kihatva a korpusz jelentős részére.

A Papírváros falai között artikulálódó szövegtér feltérképezésének szempontjából ugyancsak meghatározóak a regénynek azok a jellemzői, amelyet a kritika ugyan számba vett, anélkül azonban, hogy ezek egymáshoz vagy a tágabb magyar és világirodalmi kontextushoz való viszonyát érintette volna. A Papírváros egyes darabjait olvasva szembetűnők a szövegalakítás, történetbonyolítás szintjén jelentkező strukturális és elbeszéléstechnikai megoldások: a „mozaikszerűen épülő, asszociatív megidézésű emlékező”. 516 narrációhoz társuló önreflexív, a folyamatos szövegalakító jelen-létet hangsúlyozó réteg; az „anekdotikus eseménysorok és a szerzői funkció megnyilatkozásainak” váltakozása. ${ }^{517}$

Másrészröl minden eddiginél hangsúlyosabban jelentkezik a szex-szcéna és pornográf jelenetezés, a nemiség, a szexualitás tematikája és metaforikája, mely azon túl,

\footnotetext{
513 TOMPA Andrea: Horror poeticus, Zalán Tibor: Halvérfesték. http://www.lap.szinhaz.hu/htm1/2001apr /halvervestek.shtml) (2005. 05. 07)

${ }^{514}$ H. NAGY Péter: i. m. 160.

${ }^{515}$ Vö. ELEK Tibor: Folyamatos küzdelem a hiteles formáért. Különös(en) posztmodern (ön)reflexiós beszélgetés Zalán Tiborral. Bárka, 2000/2. 11.

516 JuHÁsz Attila: Emberszag, magányszag. Tiszatáj, 2003/2. 110.)

${ }^{517}$ FEKETE J. József: , Ügyesen szétgondolt olvasat” Zalán Tibor: Papírváros II. Új Forrás, 2003/5. 74.
} 
hogy „meghatározza az egész mü stílusvilágát is a vulgár-naturalizmustól a lirizált, szimbólumokban gazdag romantikus vagy éppen szürreális láttatásig", ${ }^{518}$ elsősorban nyelvhasználati, prózapoétikai kérdés. Hiszen a „pornográf jelenetezés filmszerünek tűnő alakítása [...] nem mindig a tárgyhoz való automatikus hozzáférés elvére épül, hanem több esetben annak elbeszéltségét is színre viszi."

A szerző és az építész-narrátor hasonló törekvései, a szövegen/testen végzett lankadatlan munkálkodásuk a szöveg(test)építés olyan módozatai, melyek egyaránt egy literarhitektúra részeként értelmezhetők. Az interdiszciplinalitáson túl többek között a különböző művészeti ágakban egyaránt jelentkező önkifejezési problémák és nyelvhasználati dilemmák hívták életre az építészetnek és irodalomnak azt az egymásra vetíthetöségét, amelyben a kölcsönös metaforikus átjárhatóságon túl, találkozik egymással az épületek olvasása és a szövegek építészete. Paul Valéry Eupalinosz, vagy az épitész címü dialógusáról szólva Berta Erzsébet hívja fel a figyelmet az építmények és építészet külön státuszára, „hogy úgy tudjuk őket befogadni, miközben ők fogadnak be minket”. A platóni dialógus mintájára szerveződő szöveg beszélőinek „költészetről szóló elmélkedései is az építészeti mintát variálják. Szókratész azt a versírót tartja költőnek, aki úgy tekint a nyelvre, mint ahogy az építész az architekturális formákat rejtő építőanyagokra", mely megközelítésben a nyelvi müködés, a szövegalakítás variabilitása az elsődleges. „Íme, a nyelv itt építész lett?” - olvasható Valérynél, és „ez a nyelv, a költői nyelv nem szemiotikus, hanem architektonikus" - állapítja meg a tanulmány szerzője. ${ }^{520}$ A magát Ybl-díjas építésznek tituláló elbeszélő-szereplőnek a regényben tematizált módszeres önleépítő, bomlasztó és elszigetelődö törekvései a történet szintjén a test határainak, a vegetatív létezés szélsőségeinek megtapasztalásával társulnak. Az animális létezés bizonyos fokán összemosódik emberi és állati, a magánszférát elözönli a (vég)lények hada. Jack Kerouac-i „végtelen körben foganó élölények / vicsorognak a Tudatban”. ${ }^{51}$ a citromfej-nő és fekete lepkéi vagy a madárfejü gólem apa; Samu, a rotweiler; Atma, a korcs világlélek; a nyúl-áldozat és barnamedve. A ,mi a faszért vagy nagyobb állat, mint amekkora vagy" (II. 139.) kérdés nyomán, ezek a férfi-nő viszonyt, egyesülési módozatokat meghatározó létformák, a lehető legtágabb értelemben vett testiség

\footnotetext{
518 JUHÁSZ Attila: i. m. 112.

${ }^{519}$ H. NAGY Péter: i. m. 157-158.

${ }^{520}$ BERTA Erzsébet: Literarchitektúra. Alföld, 1999/3. 73-78.

${ }^{521}$ Jack Kerouac: Mexico City Blues 211. Kórus. Ford.: Eörsi István. (Bármely kiadás.)
} 
megnyilvánulásaiként, az identitásképzés, az öndefiníció kísérőjelenségeivé válnak. ${ }^{522}$

Az önazonos, pontosan körülhatárolható szubjektum képzetét, és az ezzel járó határozott diszkurzus-pozíciót elbizonytalanító abjectek, anyagcserés képződmények, a különböző testi váladékok, a szervezetből kiáramló fluidumok állandó jelenléte egy köztes létmód, átmeneti állapot szituációjából fakadnak. E beszéd és léthelyzet során a testbelsővel mint hitvány, undorító mégis nélkülözhetetlen anyagok tárolójával konfrontálódik a narrátor: „a rohamok pedig nemritkán hányásban végződtek, államat a mellemhez szorítva okádtam, végigcsurgott meztelen felsőtestemen a nehézkes, nyúlós vörös lé”. (I. 35.) A saját test materiális tapasztalata ugyanakkor minden esetben ennek színrevitelével párosul, ,az én magam lépek be magamhoz” önanalízise jegyében.

A vegetatív, biológiai létmód és megnyilvánulásai ezen a ponton találkoznak egy produktív, szellemi réteg kifejezéseivel, az elbeszélő pedig e kettő folyamatos oszcillálásával lendül kitüntetett határ-helyzetbe. „Te tetted ezt magaddal / Te lettél azzá, ami vagy / Lehettél volna, de nem lettél más mégse: / Éjjeli test, nappali agy" fogalmazódik meg e kettősség a Mr. Pornowsky címü Zalán-darabban felcsendülö Müller Péter dalbetétben.

A regény-szereplő félmerev hímtagja mint egyetlen biztos kapaszkodó, a „kakasbutter” nyelvi viszonyulási pontjához hasonló fogódzó gyanánt egyúttal a szövegtest nyúlványa is, testszövet, mely e tekintetben különbözik leginkább a lány apjának élettelen szervétől. A narrátor többnyire e kettősség okán egyidejüleg viszonyul a „férfimágnes” (= kakasbutter, I. 36.) megfoghatatlan szóhalmazához, és a kézhezálló húsdarabkához: „a kakasbutteres flakont nézted ilyen megátalkodott kétségbeeséssel, amikor fürdés közben elfogott a köhögés és hányinger, kapaszkodtál az árva faszodba" (II. 133.) E szótestkupaccal szemben, az apai hímtag viszont a leírások, naplórészletek, történetek tárgyaként nem gazdája, a „őshím” számára inkább - a belőle eredeztethető, hozzá kötődő - lány, és a regény szereplőinek jelent viszonyítási pozíciót. („Nézem az apámat, ahogy részegen ül a konyhában, és kilóg a fasza. Innen jöttem. És hová tartok”) A „hortyogó állat” és „vastag nemi szerve” egymás meghosszabbításaiként, egy és ugyanazon szereplő gyanánt ékelődik a narratívába, és leginkább az incesztus vizionált aktusában elevenedik meg; annak a (hagyomány)történetnek a kezdeteként, amelynek folytatása a lány, ivarszervi alternatívája pedig a férfi, mint „,balfasz”. A lány élettörténete fölé tornyosuló

\footnotetext{
${ }^{522}$ A test, testiség mint éntapasztalat, és szubjektumszervező terep szempontjából alapvetőek a kérdés pszichoanalitikus és filozófiai vonatkozásai. Erről magyarul lásd pl. VeRMES Katalin: A test éthosza (A test és a másik tapasztalatának összefüggése Merleau-Ponty és Lévinas filozófiájában. L’Harmattan, Bp., 2006.
} 
apa, és az ennek elbeszélésébe benyomuló testrész a narratívát erőszakos behatolásával ékként feszíti szét (,olyan nagyméretű az apja, hogy nem tud csak úgy egyszerűen betörni a testébe”). (II. 229-233.) Ugyanakkor az apa kasztrációjának végrehajtásával fogadja igazán magába a meghaladni, lerázni vágyott testet. A testnedvek egymásba folyásával, a testhatárok (apa-lány) felszámolódásával, az elbeszéléshez szükséges distinkció is felfüggesztődik; a női hang önmagát szünteti meg, elnémul. A két fasz(i) között elfoglalt korábbi disszonáns határhelyzet elveszésével a lány is a papírváros egyik rekonstruálandó hősévé válik: „Nem / úgy volt / Nem úgy hogy / volt egy áldozat / - maga, egymaga - / és hozzá rendelve / sorsához / a gyilkosa - s ez / utóbbi én lehettem". 523

A nemiség filozófiájának és szépirodalmi hagyományának termékeny egyesülésében a szereplők meztelenségükkel, kiszolgáltatottságukkal és a testnyílások feltárásával a behatolás illetőleg átjárhatóság nyelvi műveletét szabadítják fel. („mindenkinek rá kell pillantania a széttárt combú nőre, sőt, köpködni is lehet, bele a pinájába" I. 55.) Mindez így elsődlegesen nem is stilisztikai vagy szexuálesztétikai kérdéseket vet fel, inkább a (szöveg)test-építés ornamentikájának részeként a nyelvben, nyelv által létezés terében egymásba folyó szexus/textus relációit. A Papírváros első részének egyik központi, a cselekményt is továbbmozdító része éppen a rés, az (ajtó)nyílás beszükülésével párhuzamosan, az önmagába zártság és testhez kötöttség visszafordíthatatlan fellazításához járul hozzá egyértelmúen. A lakásából kizárt, a hőségben a küszöbön vizionáló férfinek nem csak a tudatában folynak egymásba az események, mely állapotváltozás éppen a „nyelvhasználat” közben felvetődő névadási és önmeghatározási kísérlethez tapad szorosan: „hagytam, hogy a kutya tovább nyalja a talpamat, mind hevesebben és egyre nagyobb hozzáértéssel, Christine, csúszott ki a számból és verődött a kőhöz az egyetlen szó, amit ebben az állapotban kimondhattam [...] nem bírtam tovább, elengedtem magamat, magamtól a testemet, mely bő áradással szabadult meg azonnal fölösleges terhétől”. (I. 127.)

E szövegrész a nő és az állat kölcsönös egymásra fordításával egyben a metafora retorikai alapelvét, a hasonlóságon alapuló áttételt is tematizálja, miközben az emlékezés narratív kategóriáját (felidézés, megidézés) az intertextuális egyik módozatként emeli a szövegalakítás aktusává. Az eset felvezetésében reflektált primer lét-metafora (csapkodó úszással fennmaradás - élet, I. 125.) helyét a szubjektum fokozatos fellazulásának, cseppenkénti kipergetésének hatására a második könyv végére a fél-hasonlat, a „haszonlat”

\footnotetext{
${ }^{523}$ ZALÁN Tibor: Rekonstrukciós kisérlet a Papírváros höseinek megteremtéséhez, = UÖ.: A szürrealista balkon. Versek és (mű) fordítások. Kortárs, Bp., 2004. 68.
} 
szövegszervező eljárásai, az elhallgatás, a lezáratlanság veszik át. (II. 267.) Az életmü meghatározó poétikai irányultságának egyik példájaként ez a szövegszervező aktus a szerző korábbi, a hasonlat 3. fele címü versében is ,,a kitakarva hagyott test” módozataival társul. A költői szöveg alakulása során a lemeztelenített retorikai jelölők, szöveg(test)nyílások szabaddá tételével, kitakarásával igyekszik egy „kicsit / lendíteni életen túlra!"524 „A megismerés tárgya és médiuma - Alexa Károly szavaival - egyszerre és egy időben a zsigeri világ, a test legkülönbözőbb termékei, ahol és amelyekben a létezés és pusztulás elkülöníthetetlen, a test mint alvilág, hasonlat és megnyilvánulás". 525

A Papírváros I. fent említett szövegrészében az ejakulációt követő bevizelés medrében a szöveg-folyam végül a név hívószavával elindított metaforikus aktussá duzzad, és kozmikus méreteket öltve kiterjed a környező élővilágra is, a „párzás az egyetlen autentikus cselekedet" felismerésének jegyében. (I. 142.) Ez az autentikusság pedig leginkább a szövegvilág részeként bizonyul fenntarthatónak, ahol az eredeti forrásként csak egy másik szövegtér jelölhető meg. A fiziológiai cseppfolyósság hétköznapi tényszerüsége így éppen a homonímia szemantikai relációja révén szivárog át a nyelvi struktúrába, többértelmüsítve ezzel a bevizelés fogalmát. A Bevíz Elek zaláni dráma-figura elindította Bevíz-elés teljes egészében a nyelvi produktum szintjére helyezi a (szöveg-elés) és a bevizelés tényét, így a „kínos ügy” immár irodalom- és színháztörténeti momentumként aposztrofálódik. ${ }^{526}$

A szexus széles skáláját bejáró (a testiség kiterjedt vizuális és szaglási ingerkészletét beemelve) a hús legkülönbözőbb megnyilvánulásaival feldúsított szöveg brutalitása és obszcén retorikája a nemiség szemiotikájára, a szexualizált hatalomgyakorlás ideológiai összetevőire fokozottan ráirányítja a figyelmet. A nemiség identitásképző alaptapasztalatai, a testi közvetítettség permanens regénybeli megnyilvánulásai leginkább a szex szemiotikájának jegyében olvashatók. „Az emberi szellem testiségének, testhez kötött mivoltának felfedezése kérdőre vonja a testet, jelként kezeli, a szellem jeleként. Az erotika a test szellemi értelmezése, a szellem felfedezése a testben" - fogalmaz Király Jenő az erotika hermeneutikájáról szólva. ${ }^{527}$ A más típusú mủélvezetet ellehetetlenítő aktusleírások a pornográf ponyva- és filléres regények ellenében, ezekre reflektálva nem teszik lehetővé,

\footnotetext{
${ }^{524}$ ZALÁN Tibor: Kívül. Jelenkor, Pécs, 1993. 37.

525 AleXA Károly: „... a nyelv nevü léghajó szánalmas nehezéke”. Zalán Tibor: Papírváros (egy lassúdad regény, egy - kimerülve), Kortárs, 1998/12, 88-100. [A félkövér kiemelés tőlem. B. S.]

${ }^{526}$ Lásd: ZALÁN Tibor: Bevíz úr hazamegy, ha ... címü darabjának szegedi bemutatója körüli botrányt. Vö. Hollósi Zsolt: „Elfogynak a régi izek, csak a mítoszok maradnak meg” Beszélgetés Zalán Tiborral. Tiszatáj, 2001/11. 109-120.

${ }^{527}$ KIRÁLY Jenő: Frivol múzsa. i. m. 797.
} 
a félkezes, csuklómozdulatokba belefeledkező olvasat kitermelését, hiszen a közvetlen és problémátlan örömelv az irodalom közegében megkérdőjeleződik. A narrátor nemi identitásának kialakulásában nagyobb szerepet kap a könyvtest, a szöveg öröme, mint a direkt, alacsony genitális ingerküszöb átlépése. A Papírvárosban említett Rejtö-könyv borítóján mosolygó nőalaknak ugyan „bal karját és mellét is ellopta valaki”, de még fél kézzel is maradéktalanul hódolója kedvében jár azzal, hogy megadja a jelet. Yvonne irodalmi lény, papírnő, maga a múzsa, aki csókjával hozzásegíti a narrátort Mészáros tanárnő és minden későbbi „tanár-nő” megragadásához.

A „szárnyaló szeretkezések, elemi baszások, futó numerák, egészségügyi kúrások, precízen előkészített koituszok, impotens hágási kísérletek és visszautasított megujjazási szándékok leírásában" ${ }^{528}$ a változatos listázhatóságon túl, az ezek háttérben egyaránt meghúzódó problematika lesz meghatározó, hisz minden esetben hús hatol húsba, szövegtest a szövegtestbe. Az átélés, megtapasztalás kínjai és lehetőségei nyomán ezek helyébe lépve, a megfogalmazás, a kimondás felvállalása kerül, az írás gyötrelme pedig az olvasás örömével párosul, mely „bizonyos törésekböl (...) származik: össze nem illő kódok lépnek kapcsolatba egymással [...] pornografikus üzenetek simulnak bele oly tiszta mondatokba, melyeket nyelvtani példamondatoknak is tarthatnánk" - fogalmaz Roland Barthes. ${ }^{529}$

Az ideológiai apparátust, a hatalomgyakorlás nemileg kódolt módozatait megtestesítő rendőr szövegrészeit az odesszai nyaralás elbeszélésének szex-szcénáival váltogató regénytechnikai eljárás e kettő egymásra olvashatóságával eredményezi az olvasás fent említett örömét. Például a saját székletében és vérében megmártózó, WC-ben összevert férfi tortúrája az elbeszélés procedúrájaként a „napon felejtett férfi” történetén keresztül az „ének a napon felejtett hintalóért” címü alapvers ironikus értelmezését, epikai megszövegezését adja. (,...ezek nem fognak velem kukoricázni, humorérzékük annyi se, mint egy napon felejtett hintalónak” I. 194.) A regénybe és az említett hosszúversbe egyaránt bekerülő életrajzi momentumok (Béke-tanszék), személyes adatok (kubikus apa, öngyilkos nagyanya) igazságértékük, valóságra vonatkoztatottságuk helyett inkább az életmű különböző darabjai között mozgó szövegelemként értelmezhetők. (A Fénykorlátozás-kötet Állom címü verse például a Papírváros kettőben elbeszélt apaszöveget szituálja újra. II. 196.) A Che Guevara-történet vagy a „Blue dolphintól spártáig” vezető út állomásai, más-más kontextusba helyezve, a „,visszafelé olvasom magam”

\footnotetext{
${ }^{528}$ FEKETE J. József: i. m.

${ }^{529}$ Roland BARTHES: A szöveg öröme. i. m. 77.
} 
versbeli poétikai eljárás jegyében a teljes életmüre kiterjedő kérdéskörre figyelmeztetnek: „az asszonyokat ondójukkal” megfertőző ólomkatonák szöveg-nemző aktusára. ${ }^{530}$

Charles Bukowski hasonló tematikájú és radikalitású életmüvének az egyik meghatározó jellemzője éppen az életrajziság és az irodalmiság hagyományos viszonyának átértelmezése, mely problematika a Mr. Pornowsky című Zalán-darab témaválasztásán keresztül is kapcsolódik az életmühöz.

A Papírvárosban tematizált pusztulásmítosz és az önfelszámoló stratégiái szövegszinten éppen a regény széttartó, a prózai szövetbe idegen test, vadhús formájában belenövő mivoltuk által biztosítják ,a heterogenitás fenntartását, miközben el is bizonytalanítják a metonimikusan zárt epikai tényezők, centrumok stabilitását". 531 A vallomásosság és magánmitológia helyén, a „modoros pusztulásromantika” részeként a testhatárok felismerésének, megtapasztalásának morális és egzisztenciális tragikuma mellé az elbeszéltség, a nyelvi megragadhatóság ironikusan kezelt vállalkozása kerül: „forgattam a felöklendezett szavakat megdagadt nyelvemen" (I. 112.)

A Zalán-próza említett jellemzői szempontjából is különösen izgalmas szövegnek tünik a Blue Dolphin című novellával (mely a kórházban olvasott „Változó Világ” szám „talált szövege”-ként integrálódik a Papírváros első részébe) egy időben, a költői megszólalást szinte megelőzve vagy ezzel párhuzamosan megjelent $A$ tanktípusú nő. Ez a novella mind narrációját, mind pedig tematikáját tekintve a Papírváros közvetlen előzményeként, alapszövegeként olvasható, textuálisan talán éppen ezért nem idéződik az eddig elkészült regényrészekben. A szexualitást, a férfi-nő párkapcsolat megalázó kiszolgáltatottságát körbejáró írás a két, váltott szólamú elbeszélő megszólaltatásával, a szerelem romantikus, idealizált és a testiség pőre, realisztikus szembeállításával a Papírváros elbeszélői határhelyzetét, (tö)rés-vonalak halózatában szerveződő prózatechnikáját idézi. A sírás alternatívájaként megjelenő öklendezés testnedve („öklömnyi vérdarabok tömítik el a torkomat, köhögök majd, szám elé kapom a kezem, s a markom megtelik vérrel”) a kimondás, megszövegezés elbeszélői erőfeszítéséhez rendelhető, mely talán éppen a „kakasbutter” nyelvi fogódzójának, bizonyosságának hiányában itt még önfelszámolódáshoz, a szöveg groteszk lezárásához vezet. A történet során hímvessző méretűvé zsugorodó férfi, a vágyott „tanktípusú” (lengedező mellü, hatalmas, marcangolható seggü) nővel egyesülve ennek áldozatává válik, „,beleid azok a színes szalagok, szétlapított testedből törtek elő valamikor”. Amellett, hogy a könyvespolcokról

\footnotetext{
${ }^{530}$ ZALÁN Tibor: Ének a napon felejtett hintalóért. = UÖ.: Áttünések-áttüntetések. Bp., 1994. 7-26.

${ }^{531}$ H. NAGY Péter: i. m. 157.
} 
lehulló könyvek az eleven irodalmi hagyomány jelenlétére is figyelmeztetnek, a befejezés testi megnyilvánulása egyúttal a hatalmi és ideológiai törekvések által befolyásolt szexus jelölője is: „félrefordítom a fejemet nehogy lehányjam a frissen vasalt egyenruhát”. ${ }^{52}$

Az elbeszélő számüzetése a trópusokra a csupa-hús kurva feltérképezésével, egyúttal a retorika világába tett kirándulás, melynek szexuális jellege önreflexív módon e szcána nyomán a szöveg popularizálódására, vagy akár prostituálódására is rámutat. (I. 27.) A szexus mint a testi megnyilvánulások értelmezést igénylő tárháza, a (szex)nyelvi kifejezések jelen-valósága (I. 47) a textus jellemzőivel ruházódik fel; és a testgyakorlat is az írás aktusának mintáit követi. („letérdelt elém, kigombolta a sliccemet, kibontott az alsónadrágomból, és erőszakosan, idegesen és elkeseredetten nekem látott, keretes elbeszélés, jutott eszembe, stílusa azért van”. (I. 58.) Másutt a szív fönévi és igei használatából adódó homonímiára reflektálva az orális nemi aktus megszövegezésével párhuzamosan ezt a romantikus költői hagyományból eredő, a szó poétikáját működtető költészeti motívumot ironizálja a szexus során, a Fénykorlátozás figyelj, cowboy! címü versét felidézve: a szív, ha szív nem is oly’ ósdi hangszer. (I. 24-25.)

A Zalán-szövegekben elbeszélt események, történések minduntalan a szövegalakítás metaforáivá, saját maguk ironikusan kifordított nyelvi produktumaivá válnak. A gyermekmóka gyanánt elővezettet pióca-kifordítás játékos csínye, az élveboncolás, a testhatárok áthágásának jegyében, a „kívülre kerül ami bent van” törekvés nyomán, a szövegtestben vérző sebként gyürüdzik tovább. (II. 92.) Nem meglepő tehát, hogy 2004-ben megjelent, Szürrealista balkon címü kötet több versében előfordul ez a kép, éppen a testiség nyomán megnyíló réseket övezve: „nincs emlék és / nincs jelen csak kitárt / pinában kutató / száj és a nyelve van". ${ }^{533}$ Figyelemre méltó továbbá, hogy e verseskötet záródarabja éppen egy Tonio Kröger (mü)fordítás, amely a lírai megszólalást visszamenően is „,a/ Papírváros riasztó/ üres rideg beteg fényeivel” világítja meg.

A test nyelvének kifejezése itt is a nyelv testiségének közegében zajlik, a szexus és textus metszéspontjában, hiszen „ha az ember létértelmezésének középpontjában a test van, akkor az értelmezés logikája a test létezés kontextusába lép át". 534 Zalán Tibor megfogalmazásában pedig: ,a / határokat nem elménk szabta / hanem testünk égette tönkre // testünk égette tönkre testünk". 535

\footnotetext{
${ }^{532}$ ZALÁN Tibor: A tanktípusú nö. Alföld, 1980/11. 23-26.

${ }^{533}$ ZALÁN Tibor: Januári elégia. = UÖ.: Szürrealista balkon, i. m. 65.

${ }^{534}$ G. L. TULCSINSZKIJ: Ige és test a posztmodernben. http://www.c3.hu/ p prophil/profi021/tulcsiszkij.html (2005. 06. 15)

${ }^{535}$ ZALÁN Tibor: Sem szárnysuhogásban. = Uö.: Szürrealista balkon, i. m. 82.
} 
A papírváros építményének a férfi és a lány kapcsolatában megnyilvánuló díszletei, a teljesség iránti vágy, kifejezési szándék a szerzőnek a nyelvvel, saját szövegeivel és az irodalmi hagyománnyal való kölcsönös összefonódásában teljesednek be/ki. Valéryt idézve „úgy tudjuk őket befogadni, miközben ők fogadnak be minket”. Árulkodó momentum, hogy a regényben a nemzés aktusáról elmélkedő Bandit kis híján agyonüti az ezt a bölcseletet elviselni képtelen Galadér, miközben a szereplői szólamban a Byron-idézet újraszituálása ellenére, a didaxis egy potenciális építőelem, a terméskő alá szorul. „repül a nehéz kő..." (I. 182.)

Zalán Tibor regényeinek literális díszletfalait az obszcenitás és trágárság különböző megnyilvánulásai, a pecsétek, kilövellések, öklendezések megannyi nyelvi lenyomataként a saját és a magyar irodalom folyamatos jelenléte színesíti. A Szabad-ötletek jegyzékének obszcén, nyers szókimondó szövegtartományának, Hajnóczy Péter prózájának - az alkoholizmus párhuzamain túlmutató - az önpusztítás testroncsoló mechanizmusaival és a szexualitás húsbavágó tapasztalatainak (Embólia kisasszony, Veseszörp, Nagymama beszáll) továbbépülése a Zalán-regény literarchitekturális szövegtere. Nem utolsó sorban pedig a költő-barát, Sziveri János lírai testtér- és vérképének mérnöki pontosságú rendje, melyben például régi magyar irodalom egyik alapszövegén élvezkedve fordul a (szöveg)test adta - a költői hagyomány kimeríthetetlenségéből eredő - lehetőségekhez. ${ }^{536}$ A Siralmas énnéköm a jól ismert Bornemissza-vers („Siralmas énnéköm tetüled megváltom...”) variációjával, az elhallgatás, hiány poétikája jegyében az „farkával az markában” egyetlen örömforrásként a szex/textust jelöli meg, mely nyelvgyakorlat („fúrok s versfaragok") során a verbális ejakuláció eredménye lesz maga a versszöveg. ${ }^{537}$

$\mathrm{Az}$ irodalmi (ön)építészet művészete tehát korántsem függetleníthető a nyersanyagtól, a (szöveg)testtől. A testiség, a hús egyaránt alapanyaga és kiindulópontja az építő- és nyelvmüvészetnek: ,a legszuggesztívebb metafora, amit a közelmúlt építészei épp hogy elkezdtek használni, a modernizmus organikus tradíciójából nőtt ki, és igen szorosan kapcsolódik testi képzetekhez és ahhoz, hogy az ember a természeti és állatvilág folytatódása.” A posztmodern építészet korában ,az az építész, aki belenyugszik, hogy szerepe nem több, mint jelentésteli régi klisék - érvényes közhelyek - új összefüggésbe állítása”. 538 „The tree of knowledge hat been pluck'd - all's knovn” - idéződik a

\footnotetext{
${ }^{536}$ Vö. VIRÁG Zoltán: Test(tér)kép. (Sziveri János költészetéröl.) Korunk, 1997/9. 79-88.

${ }^{537}$ Vö. Sziveri János minden verse. (Szöveggond.: Utasi Erzsébet.) Kortárs, Bp., é. n. [1996.] 163.

${ }^{538}$ KunszT György: A posztmodern épitészet antropomorfizmusa és dekonstruktista elvetése. Alföld, 1999/3. $65-72$.
} 
Papírváros(ok) első soraként a Byron-mottó. ${ }^{539}$

A Papírváros architektúrája - melynek szerves részét képezik a költői életmü belső terei, épület-elemei - tehát leginkább poétikai törekvéseinek vonalát követve értelmezhető, ahol a test határainak megtapasztalása az elbeszélhetőség, a nyelv végességének problematikájával találkozik. A zaláni szövegtér literarchitektúrájában a költészetének alapvető motívumai az epikai boltozatba ágyazódnak. A Lassú halált játszik Lepke címü verse például a transzcendens történést éppen a (szöveg)test felyitásával a nyelvi újrarendezés és megszövegezés tettével helyettesíti. („Végre szégyen / nélkül /párolgó húsába marhat / Fölöttük megtörténik / a lepke / fenséges haláltusája”) A Papírváros I. nőalakjának állandó kísérője e versmotívum, mely köztes létmódjának, lebegtetett nyelvi és fizikai kettősségének jelölője, és a texturát alakító, másik hasonló szövegjegy, a pók szintén többször rendelődik személyéhez. („Pókra emlékeztetett, amelyik hálója sarkában ül mozdulatlan, s áldozatát figyeli, hallgattam, bámultam a plafon kék kis krátereit, pók, kínáló mozdulatomat elhárította”. (I. 18.)

A térformákat szemlélő építész, az architektúra hibáit, építménye repedésit, réseit vizsgálva nem véletlenül a „kakasbutter” nyelvi jele nyomán emeli vizuális elemmé a lepke szót (I. 32.), melyet a kötet egyik oldalán, ennek végletekig lemeztelenített grafikai képével helyettesít. (Akárha, egy lapon légy vagy lepkepiszok volna.) A lecsupaszított nyelvi és narratív fargmentumok a regénybe ágyazódásukkal „,a legkülönfélébb panelek (pl. horror, pornó, sci-fi, krimi stb., azaz a peremmúfajok) nyelvi értelemben reflektálhatóvá alakított, aktualizált elbeszélés struktúráit" is mozgatják. ${ }^{540}$ A papírváros építőelemeként szembeötlő pornográf jelenetezésen, „az idősíkok szabad váltogatásában, a gyors vágástechnikában” tetten érhető megoldásokon túlmutató filmszerüség, a regény szövegében megjelenő fordulatok, hasonlatok és konkrét filmekre tett utalások formájában is jelen van. (Roman Polanski: Keserü méz, Ny. Sz. Mihalkov: Etüdök gépzongorára.) ${ }^{541}$ Váltott narrációs szövegismétlődések ugyanakkor egyszerre idézik a hasonló elbeszélés-technikájú előszövegeiket, és ezek filmes adaptációinak képi világát, filmes narratíváját. Így például az epizódszerü, kisebb szövegegységekként egymásba épülő fragmentumok, Akutagava Vihar kapujában, vagy a Cserjésben címü szövegei mellett, a kamera-nézőpont változását, filmképi variációikat meg a híres Kuroszava-filmet is olvassák. Másutt a képi narratíva inkább asszociatív és metaforikus áthallásokat implikál, így értelmezhető a detoxikálóból

\footnotetext{
${ }^{539}$ George Noel Gordon BYRON: Don Juan. 1. rész („Az ismeretlen fájáról szakítottak - tudva van minden.") Ford.: Ábrányi Emil (bármely kiadás).

${ }^{540}$ H. NAGY Péter: i. m. 156.

${ }^{541}$ JUHÁSZ Attila: i. m. 113.
} 
kilépő férfi (ön)magába zártságába pusztító szélként benyomuló külvilág húsroncsoló kozmikus látomásaként, sőt Paul Verhoeven Az emlékmás (Total Recall, 1990) címü filmje záró jelenetének és egyéb mozgóképi szövegek továbbírásaként. ${ }^{542}$ („,teste rángatózni kezd, egyszerre haja leválik a koponyájáról [...] előbb kimeredt szemei pattannak szét az üregükben”, II. 62.) ${ }^{543}$

A film föszereplöjének, Arnold Schwarzenegger testépítő világbajnok arcának szétrobbanása, nemcsak izmos jóképüségének darabokra foszlásával jár, de a test felszámolását, türöképességének maximumát épp a regényben tematizált testkupac megképzésével éri el a szöveg (nem függetlenül Paul Verhoeven másik, Hús és vér [Flesh and Blood, 1985] címü filmjétől). Ugyanakkor a testiség, a hús és a vágy tárgyának színrevételében a két kifejezési forma (képi és írott) hasonló nyelvi, retorikai megoldásaira, és a médiumtól függetlenül egyaránt alapvető problémákra fókuszál a tekintetet. Így a Papirváros kettóben a férfi és fiatal lány közötti dialógusban a név elhallgatásában és a kimondását helyettesítő nonverbális, testi kommunikációban Az utolsó tangó Párizsban anonimitás és animalitás iránti érdeklődése, továbbá a többek között Pedro Almodóvar Matadorjában megjelenő, halálba torkolló szerelmi beteljesülés kérdésköre is elökerül. (II. 140-148.)

A literarchitektura legkülönbözőbb eljárásai során, többek között Konrád György Városalapítójának tér-forma metaforikájához illeszkedve, a Zalán-próza (is) mindvégig "a húsáró1/ beszél. [...] A húsáról/ a beszélnek". 544 Ebben a szöveg-geometriában a papírhajtogatás müvészetének meghatározó aktusa az „írni - ugyanazt” ars-poétika részeként, a forma-adás verbális müveletének mániákus megvalósulásaként értelmeződik. A „hajtogatás” önismétlő gesztusa, (szöveg)építő eljárása pedig egyaránt sajátja az irodalomnak és építészetnek. Deleuze természet- és kultúrfilozófiájában a forma-adás lényegét a japán origami-játékban érvényesülő technikához hasonlítja, ,amellyel egyetlen papírlapból a legkülönbözőbb alakzatok hozhatók létre egyes-egyedül hajtogatás révén". 545

A papírváros önéletrajzi epizódjai, a magánmitológia egyes állomásai, olyan felületi gyürődések, visszamaradó papír-redők, melyek az életmü különböző szöveginek formaadó gesztusai nyomán mindig más és más rajzolatú textusként jelentkeznek. A gyürt

\footnotetext{
${ }^{542}$ Ez a jelenetsor Verhoevennél filmes átvétel vagy idézet, a Gyilkos bolygó címü, Sean Conerry főszereplésével készült 1981-es Peter Hyams filmből, ahol Az emlékmáshoz hasonló módon a kigúvadó szem és foszlányaira szétpukkanó fej képi megjelenítésével idézte a szubjektumnak fent említett szétszórtságát, jel(zés)szerü, képlékeny kontúrjait. [Virág Zoltán szíves szóbeli közlése alapján.]

${ }^{543}$ Déry Tibor Szerelem címü novellájában hasonló, a szöveg retorikájával szorosan összefonódó eseményeit szintén fiziológiai állapotváltozás kíséri. Lásd: a disszertáció Déry-fejezetét, különösen 125.

${ }^{544}$ ZALÁN Tibor: Zene. = UỎ.: Lassú halált játszik, i. m. 32.

${ }^{545}$ KunsZT György: i. m. 71.
} 
felületek kisimítása nyomán a hajtogatás által a szövegtest legkülönbözőbb mintázatait adják. Ez a következetes, önkínzó, a nyelvi közvetítettség és elbeszélhetőség írói dilemmáját a testiség, a szexus színrevitelével társító eljárás, a mozgó testek nyelvében megnyilatkozó poétikai törekvés alapján körvonalazható: „grammatikai viszonnyá tenni / a puhatolózó érintéseket”. ${ }^{546}$ (,az egyetlen nőé, aki a mozgó testek nyelvéről beszél valakinek, érzed, ahogy a mozgó nyelvén mozognak a karcsú, meztelen testek” II. 37.)

Charles Bukowski (ön)figuráinak állandó törekvése a szexus létrehozására az az alap, mely a létezés feltételeként lehetővé tesz egy rétegzett, filozófiai és mitológiatörténeti értelmezhetőségét. A „szarkupacra emlékeztető” költemények szókupac jellegét pedig éppen a testiség folyamatos prezentációja hozza létre. A Fénykorlátozás szómontázsai a testlikőr, testlekvár, testgubanc stb. a Papírváros regényfolyásában ekként találkoznak ,az ürülék, szóürülék, ürülékszó” (II. 93.) hulladék-anyagaival átitatva egymást: „Szavakat látott maga előtt, magában és párálló női testet a szavakon [...] szavakat a párálló női testen, ráírva, ráterítve, tetovált vagy lettraset betükkel összemocskolt test, testkupac, szókupac, szótestkupac, szemérmetlenül kitárulkozva" (II. 264.) A testépítés módozatai a bodybulding és kaka(s)butter egyaránt szóhalmaz, testszöveg, vagyis intellektuális szarkupac: almaszar. (II. 152.)

A papírvárost felépíteni szándékozó bárminemű kritikai diskurzus persze legfeljebb a kártyavár-állítás pillanatnyiságával rendelkezhet.

${ }^{546}$ ZaLÁN Tibor: 5. elégia. UÖ.: Fénykorlátozás, i. m. 82. 


\section{Könyörtelen éden, avagy a szövegterek burjánzása}

(összegzés)

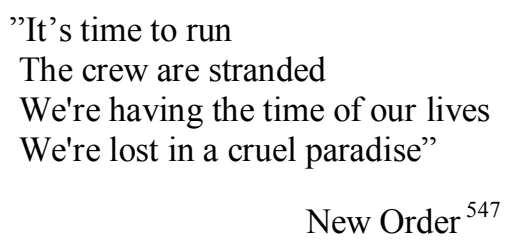

Az autóbuszok és vegytisztító cégek kamionjain olvasható METAФOPE $\Sigma$ felirat a görög köznyelvi szó, egyszersmind a (név)átvitel fuvarozott, szállított változata. A metafora a kulturális kontextus, uralkodó diskurzusok, nyelvszemlélet- és felfogás többszörösen áthelyezett viszonyrendszerében, de alapvetően mégiscsak hasonlósági alapú áthelyezés, áthelyeződés. Az alakzattól a fikcióig vezető, metonímiáktól és metaforáktól rögös út leginkább metaleptikus (Gérard Genette), semmi árnyék, pihenőhely, netán oázis. Színes, csábító és hívogató szóvirágos kertje, könyörtelen éden, a beszéd alakzatainak illuzórikusságában Júdás ezüstjei is „képüket veszített pénzérmék” (Nietzsche). A feloldhatatlan ellentétek mégis kihívó terepe ez, ahol "a művészi szövegben ideális esetben minden szó trópus” (Jurij Lotman), ám ahol „a nyelv mint trópus mindig megfoszt” (Paul de Man). Akkor is, ha a metaforák, azok, amelyek „állandó kapcsolatot létesítenek a világegyetem és az ember között"? (Alain Robbe-Grillet) Vagy mi történik, ha a jelentésátvitel, az irodalmi fikció mondjuk, a mese csapdájába kerülve, ,a növényi beszéd fantasztikus” volta okán „,a tölgy egy nap így szólt a nádszálhoz” (Christine Montabelli) szevasz tavasz!?

A dolgozat legfőbb célkitüzése pontosan az volt, hogy az e témát érintő müfaji, beszédmódbeli, nyelvhasználati sokféleség ellenére, vagy éppen azért, a szerteágazó elméleti kutatások figyelembe vételével, olyan szövegszerü olvasatokat adjon, melyek során belátható: a metaforikusság jelensége a prózapoétikában nem korszak, műnem vagy szövegtípus függő. Legfeljebb más-más módon, de egyaránt meghatározó jelleggel számolhatunk vele kortól és szövegformáktól függetlenül az egyes alkotásokban.

A varázsló kertjéböl a sétapálca-erdőbe vezető úton, Csáth Géza és Szini Gyula novellisztikáját tárgyalva, remélhetőleg beláthatóvá vált, hogy az elbeszélések metaforikusságának a mese müfaji jegyeivel, a mesével mint egyszerü- mégis markáns narratív formával való kereszteződésében: a metafora épp azért van, hogy ,a szöveg szemantikai tágasságát növelje”, azzal együtt, hogy beletartozik ,a költői ornamentika

${ }^{547}$ Get Ready (2001), Someone Like You. 
tárházába, s mert felhasználása révén jelenti a szöveg, hogy az irodalomhoz, vagy valamelyik alosztályához tartozik”. ${ }^{548}$ Másrészről a „mese olvasata szerint” akárcsak az emlékezet, a metafora is „egyszerre isteni és halandó, az emlék ragyogó csillagképe és a felejtés porló árnya" (Jacques Roubaud). ${ }^{549}$

A mese sokat használt, megkopott, mégis szinte végtelenül gazdag fogalma korántsem azonosítható a történettel vagy cselekménnyel, és mint hangulati elem sem utalható problémátlanul a stilisztika vagy esetleg a gyermekirodalom körébe. Csáth Géza és Szini Gyula prózáját olvasva a mese eredeti, orális hagyományához kötődő sajátságainak elötérbe helyezésével válik értelmezhetővé novellisztikájuknak „a mesélés körülményeit, társadalmi szabályait", ${ }^{50}$ valamint ezeknek szövegszerü, az irodalmi prózaformákban felbukkanó jegyeit érintő része. Király Jenő a populáris filmkultúra elméletével foglalkozó könyvében ezért is kezeli az egyszerü formákat és a mesét úgy, mint ,az új müvészet első vívmányát”. ${ }^{551}$ A mese hagyománytörténeti és beszédmódbeli sajátságai pedig nagyban befolyásolják a vele kapcsolatba lépő (kis)próza-formák megítélését is.

A Csáth-szövegekben a mese hagyományára, elemkészletére tett utalások tárgyalása a néhány példaként kiragadott novella értelmezése során azt igyekezett bemutatni, hogy az intermedialitás jegyében, a Homokember bagolyszerü jellemzése és viselkedése korántsem ötletszerüen esetleges a Szombat este című elbeszélésben, sokkal inkább az eldönthetetlenség és határhelyzet metaforikus alakjaként, alakzataként, relevanciája a hoffmanni előszövegen túl a Csáth-életmü kontextusa felől, többek között az Anyagyilkosság hasonló szövegjellemzői felöl ítélhető meg.

A mesehagyománnyal mint inspiratív szövegbázissal és eleven kontextussal Csáth elbeszéléseiben érintkező témák azonban remélhetőleg kifejtetlenül is tükrözik az életmü számtalan megközelítési lehetőségét. A mesehagyomány alapvető jellemzői közül ilyen például a fantasztikum, valamint az irrealitás és realitás viszonya, melyeket a mesei jelkép az ősi, epikus hagyományból felidéz, és amelyek a Csáth-írásokban is megjelennek. Külön tárgyalást igényelne, s az eddigi belátásoktól elválaszthatatlan, a most csak érintett, ám Csáth novellisztikájával kapcsolatban szintén megkerülhetetlen sajátság: a mesei vágyfogalom és a vágykiélés problematikája.

\footnotetext{
548 Tzvetan Todorov: Poétika. In: BóKAY Antal - VILCSEK Béla: A modern irodalomtudomány kialakulása. (A pozitivizmustól a strukturalizmusig, Szöveggyüjtemény.) Osiris, Bp., 2001. 588.

${ }^{549}$ Lásd. Jacques RouBAUD: Költészet és emlékezet. (Leoprepész fiának találmánya.) Typotex, Bp., 2007. 12.

${ }^{550}$ KIBÉDI VARGA Áron: Népmese és irodalomelmélet. = UÖ.: i. m. 101.

${ }^{551}$ KIRÁLY Jenő: Mozifolklór és kameratöltőtoll. i. m. 143.
} 
Feltehető, hogy Csáth az ősi „összmüvészet” kifejezési formáját keresve szükségképpen folyamodott a mese müfaji jellemzőihez a kor irodalmi formájában, a novellában kifejezve ezek tapasztalatait, belátva, hogy a mesék kora - elvesztve kapcsolatukat korábbi közegükkel, az oralitással - bizonyos tekintetben lejárt; a mesemondásé azonban nem, csak más formát kapott. Csáth Géza egy olyan mese-alapozású elbeszélő hagyományhoz köthető, melyek archaikus, eredeti formájában ott a mesemondás- és hallgatás archaikus tapasztalatával összefüggésben a csáth-i tudományos világkép és modern pszichológia számos felismerése is.

Szini Gyula novelláinak mesei jellemzői sem lírai hangoltságukban, ábrándos visszafogottságukban stb. keresendök. Szövegei a mesét nem pusztán stilizáló vagy egyszerü hangulati elemként érintik, olyan megközelítést sejtetnek, mely korát meghaladó módon az irodalmi szöveget tágabb kontextusában, egy literális hagyomány részeként kezeli.

Túllépve például az ún. lokális metaforák vizsgálatán, ezek szövegben kifejtett stiláris és retorikai hatásán, Szini Gyula novellisztikájában (többek között $A$ rózsaszínü hó vagy $A$ sétapálca-erdö címü szövegekben) a metaforikusság már nem pusztán a szükebb értelemben vett stílus szintjén érhető tetten, például az elbeszélő(k) vagy a szereplő(k) szólamában megjelenő metafora-típusú szóképek (hasonlatok, megszemélyesítések) gyakori használatában. A nyelvészeti, stilisztikai megközelítésekből ismert képi stíluseszközök vagy stilisztikai alakzatok számbavétele helyett ezért például $A$ smaragd címü elbeszélés címadó kifejezése olyan szövegszervező trópusnak tünik, amely a szerzői reflexivitás terepeként a gondolkodásban, a megismerésben, és ezáltal a szöveg befogadásában is számottevő jelentőségü.

Remélhetőleg e szerzők életművének részletes áttekintése, és teljes körü filológiai feldolgozása nélkül, a disszertációban szereplő szövegközpontú olvasatok alapján belátható, hogy egy korábbi időszak elbeszélői törekvései, az alapvetően más szempontokat mozgató kanonizációjuktól függetlenül is tartogatnak érdekességeket, továbbgondolható felismeréseket a metaforikus prózamodell szempontjából.

A trópusok játékterében a metafora is leginkább tudományágak, diszkurzusok, megszólalásmódok és nyelvi regiszterek közötti cserekereskedelem, olyan transzláció (translatio), melyben eme átültetés - miként az irodalmi művek más nyelvre történő fordítása - még egy-egy diszciplínán belül, jelesül az itt vizsgált kérdéskör (a metaforikusság retorikai, tropológiai megközelítés) kapcsán is számottevő megközelítési különbségeket eredményez. Mindez csak hatványozza az egyes trópusokat, alakzatokat 
külön-külön, vagy más-más csoportosításban tárgyaló korpusz összetettségét. A trópusok mesekertje szövegtér, az irodalmi fikció útvesztőivel, az imaginárius topográfiai terepe, melynek zúgása, morajlása a retorikai gépezet zaja, és a szorgos (szöveg)összehordó lények, a méhek döngése. Az „útbejárás rituális aktusai” (Faragó Kornélia) során együtt zsong a mesék archaikus tam-tamja, és a retorika rovarjainak nyugtalanító alapzaja.

A metaforaelméletek tételes áttekintése és tudománytörténeti összefoglalása helyett e vizsgálódások leginkább azt a tényt kívánták jelezni, hogy a kultúra legkülönbözőbb területei, jelenségei kapcsán vizsgálhatók a kommunikáció és a nyelv szemiotikai összefüggései. Hiszen egy kultúra jelei, jelrendszerei, miként például a pszichiátriai kezelés az összes apró részletével, szövegekben nyilatkoznak meg. Kommunikációelméleti szempontból a kulturális kódok akár a vallás, a művészetek vagy a hétköznapi élet jelenségeit érintsék is, egy kölcsönös és dialogikus folyamatban, a kódok, jelrendszerek illetve az ezeket értelmező interpretáns viszonylatában, a nyelvhasználat összefüggésrendszerében érdekesek. Jurij Lotman és a kulturszemiotika ezeket a trópusokat mint kulturális kódokat a szöveg és kontextus fogalmával kapcsolta össze. A metafora így retorikai jelenségből, szövegszervező alakzatból nemcsak a kultúra jelenségeit, strukturális szerveződéseit leíró jellemzővé, hanem mindezt nagymértéken meghatározó jelenséggé vált. A modern művészetek és az irodalmi diszkurzus részeként ezért kapnak nagy hangsúlyt a kultúra metaforái vagy a kulturális metaforák, miként müfaji, nyelvi és stiláris aspektusaik. Ebben a textuális alakulásrendben - miként azt Bernáth Árpád megállapítja, például -,,a mese (müthosz) és a metafora közötti ismeretelméleti kapcsolat az arisztotelészi mesefogalom közelebbi elemzésével tárható fel", 552

Nyelvcsap(ol)ások nyomvonalán haladva, a disszertáció másik nagyobb részének elsődleges megközelítési szempontja, hogy a metaforikus próza változatos formái hogyan jelennek meg a kortárs és a legújabb magyar irodalom közegében. Ezek alapján megállapítható, a metaforikusság mint szövegszervező eljárás sok esetben a már kanonizálódott szerzők, megrögzött szövegértelmezések továbbgondolását, újraolvasását eredményezi, s néhány mai, alapvetően eltérö poétikájú szöveg esetében is uralkodó jelenség lehet.

A dolgozat ezzel összhangban, arra igyekszik rámutatni, hogy Déry Tibor Szerelem címü novellája például értelmezhető egy a 70-es, 80-as évek prózairodalmát szem előtt

\footnotetext{
${ }^{552}$ BeRnÁth Árpád: Metafora a lehetséges világok poétikájában. (Első rész: Arisztotelész Poétikája.) In: ÁRMEÁN Orsolya - FRIED István - ODORICS Ferenc (szerk.): Irodalomelmélet az ezredvégen. Gondolat Pompeji, Bp., - Szeged, 2002. 43-55.
} 
tartó, a metaforikus szövegalakítás formáit idéző poétikai, retorikai szempontrendszer részeként. A Déry-szövegben ugyanis a férfi-nő kapcsolat, illetve az ennek hiányából adódó elementáris vágy, a finom utalás- és motívumrendszer részeként, metaforikus viszonyba kerülő szavak összekapcsolásával sokrétü értelmezést biztosít e közhelygyanús fogalomnak. A Déry-elbeszélésben így a kinyilatkoztató, romantikus attitűd is az irodalmi hagyomány részeként a megragadhatatlanságának, nyelvi birtokolhatatlanságnak iróniájával kérdőjeleződik meg, a textuális müködésmódot, a megszövegezés poétikai dilemmáit téve az elbeszélés fontos tárgyává.

Závada Pálnak a Jadviga párnája sikersorozatát folytató, de ennek poétikai partitúráját újraíró, intonációját áthangoló regénye, a Milota. A nyelvben és egymásban létezés ontológiai, illetve szexuálesztétikai dilemmái e müben többféleképpen tematizálódnak, részben az élő szó(beliség), a beszéltnyelvi fordulatok, vagyis a nyelv akusztikai elemeinek kitüntetett szerepe felöl, valamint mindezt visszhangozva a méhek, méhészet bioszemiotikai, továbbá müvelődéstörténeti megközelítéséből kibontakozó metaforikus, metanyelvi réteg bevonásával.

A Jadviga párnájában megtestesült szöveg közvetlen kézzelfoghatóságának helyébe a Milotában az akusztikai kifinomultság, auditív elsődlegesség került. Könyvtestből szövegtér, az olvasás termékeny erotikájából pedig, a hangzás meddő élvezete lett. A szöveg örömét ebben a tonális rendszerben elsődlegesen a regény figurális elemeiről, tropológiai megkomponáltságáról gondoskodó retorikai (hang)jegyek határozzák meg.

Zalán Tibor korántsem szezonális kirándulása a trópusokon a Papírvárosok literális díszletfalait a saját és magyar irodalom folyamatos jeleiként, jelzéseiként az obszcenitás, trágárság különböző megnyilvánulásaival, a pecsétek, kilövellések, öklendezések megannyi nyelvi lenyomatai tarkítják. A Szabad-ötletek jegyzékének nyers, szókimondó szövegtartományának, Hajnóczy Péter prózájának az önpusztításos testroncsoló mechanizmusaival és a szexualitás húsbavágó tapasztalataival egy literarchitekturális szövegtér továbbépülését jelzik az irodalmi topográfiában.

Hajnóczy Péter dolgozatban nem tárgyalt munkássága jól példázza, hogy a szerző több alkotásában (pl. a Jézus menyasszonya címü kisregényben és e kötet több elbeszélésében, valamint a Dinamit címü drámában is) a művészet mimetikus, illetve egyszeri, teremtő voltának ősi ellentéte hogyan vizsgálható az alkotás-befogadás hagyományos megközelítésétnek elvetésével. A kreatív fogalma e közegben nem újat „létrehozó, teremtő” jelentésben, inkább negatív árnyalatú, „kreált, müvi” értelemben 
szerepel; az organikus pedig az organizmus fogalmával összecsengve, „élő, az élő szervezethez hasonlóan müködő" és mint ilyen, akárcsak a metaforikus szövegszerveződések, folyamatosan változót, megújulót jelentenek. Hajnóczy Dinamitja mint szövegszerveződés és az ezt jelölő metaforikus nyelvi alakzat, annyiban mégis organikus, eleven és változó, hogy a dinamit is „alanya és tárgya önmagának”. A nyelv figuralitása folytán dinamit szó jelentéseinek összejátszatásával, a drámacím és szövegelem folyamatos feszültségével tartja mozgásban a szöveget. ${ }^{553} A$ vese-szörp címü elbeszélés pedig éppen a szubjektum fluiditásával összefüggésben, a testi folyamatok mintájára szerveződő hasonlóság nyelvi mechanizmusai kapcsán érinti a Dinamit alapdilemmáját: „Valami, ami élő, organikus, ábrázolni képtelenség. Tehát, hogy ennek ellenére kísértésbe esünk e dolog felől, úgy vélem, ez a müvészet”. 554

Az ideológiai meghatározottságot kiküszöbölő egyik alternatíva a halál mint a fizikai testből történő kilépés, azonban a fikció szintjén egyenlő volna a szöveg fölszámolódásával, az alkotó-közvetítő szubjektum felfüggesztésével. Hajas Tibor müvészete is példázza annak belátását, hogy - Kiss Attila szavaival - „a tapasztalat közvetlensége a testtel való kísérletezéssel sem érhető el: a jel, a nyelv materialitása a testet, annak mindenfajta megtapasztalását is letakarja". ${ }^{555}$

A képtelenség „ellenére kísértésbe” esni - szövegalkotó- és értelmezői kihívás nyomán e néhány szerző talán mégsem ötletszerüen kiválasztottnak tünő egymás mellé helyezésével láthatóvá válik, hogy a mai magyar irodalomban a metaforikus szövegalakítás, az elbeszélés tropikus formációi tematikusan nemegyszer a testfelület felnyitásával, határainak átformálásával, a textust a szexus nyelvi műveleteinek mintáira szervező müködésmóddal társul. Ez pedig a dolgozat kérdésfelvetéseinek távlatában Hajnóczy Péter mellett például Mészöly Miklós, Nádas Péter, Parti Nagy Lajos, Balázs Attila, Garaczi László, Kukorelly Endre prózájának értésmódját is befolyásolhatja.

A metafora, nem egyszerüen a trópusok egyike, hanem „formanyelvként is fölfogható”. ${ }^{556}$ Ezáltal pedig lehetségessé válik a metaforikusság fogalmának a nagyobb narratív szövegegységek, sőt az intertextualitás irányába való kitágítása, hiszen

\footnotetext{
${ }^{553}$ Ezzel kapcsoltban részletesebben lásd: BORDÁs Sándor: Játék három figurával - Hajnóczy Péter Dinamit címü drámájának olvasata. In: CSERJÉs Katalin - GYURIS Gergő (szerk.): Hová lettem. A párbeszéd helyzetébe kerülni. Hajnóczy-tanulmányok. Lectum, Szeged, 2006. 183-195.

${ }^{554}$ HAJNóCZY Péter: A vese-szörp. = Hajnóczy Péter müvei. (Összeáll.: Mátis Lívia.) Szépirodalmi, Bp., 1982. 420.

${ }^{555}$ Vö. KIsS Attila: Gyönyörtelen színház, avagy a reprezentáció kitakarása. (A trauma színrevitele Hamletgépben.) Gondolat-jel, 1994/1-2. 44-48.

${ }^{556}$ Vö. OLASZ Sándor „Hagyománytörténés” és elbeszélő technikák az újabb magyar regényben. = Uö.: Regénymúlt, regényjelen, i. m. 41.
} 
Arisztotelész szerint is az emberi faj alapvető tulajdonsága e „figuratív hídverés” képessége. Ezért sem fenyegethet senkit a metaforikusság kapcsán „a parttalanná válás” veszélye, főként ameddig a „metaforának sokféle elbeszélése lehetséges”. (Benyovszky Krisztián)

Az egyszerü formák alapvető elbeszélői- és világtapasztalatainak egyikeként a mese kívül esik a zárt irodalmi müfajiság kategóriáin, nem szorítható be semmiféle stílusirányzatba, sokkal inkább a mindenkori irodalmat inspiráló, annak alapjául szolgáló hagyomány, melynek jellemzői szoros kapcsolatot mutatnak a nyelvvel, mint kommunikációs eszközzel, valamint a szimbolikus rend szocializáló jellegét támogató struktúrával. Ahogy arra Kibédi Varga Áron a 70-es évek végén felhívja a figyelmet „a mesét és az elbeszélést vagy regényt nem radikális, hanem csak relatív különbségek választják el egymástól”, ezzel összefüggésben pedig „a mesekutatás módszereit azért is át kell ültetni más alkotások területére, hogy jobban lássuk az irodalom, a televízió, a szórakoztatási ipar mese jellegét", 557

A kulturális terek és megszólalási formák egymásra és egymásba rétegződésével megképződő intertextuális és intermediális formációk nem kevésbé hagyatkoznak a hasonlóság-alapú áthelyeződések, a metafora és metonímia alapvető trópusainak mozgásrendszerére. Vagy ahogyan Orosz Magdolna fogalmaz: az intertextualitás „,tágabb értelemben a szövegek egymásra utalásának, illetve szövegeknek müfajokra, beszédmódokra, tudás- és gondolati rendszerekre való utalásának" kérdéskörét érintik. ${ }^{558}$

A nyelv és kultúra - kontextuális jellegénél fogva - a mai filozófiai, kultúraelméleti gondolkodásban olyan „transzkulturális” tényezővé vált, melyben „a nyelven inneni tapasztalatok, a nyelvbe még nem foglalható mozzanatok - értelemtörténésekként egybefogó jellegűek". ${ }^{559}$ Mindez pedig az ember kultúraalkotó- és értő tevékenységét függetlenül az ezeket hordozó, közvetítő médiumok formájától az állandó szüntelen olvasás és értelmezés folyamatában ragadja meg. A távlati tudás és mủveltség virtuális közegében a „humanoid lény” szellemi mozgásterének határtalanságával, a kultúra közvetítésének „földön túli” intézményi, infrastrukturális és technikai távlatai ellenére, a léttapasztalatot, közösségi emlékezetet és hagyományt hordozó (anya)nyelv, mégsem szakadt el rejtett szálaitól.

A személyes emberi lépték, miként egy disszertáció, a maga terjedelmi és egyéb

\footnotetext{
${ }^{557}$ KIBÉDI VARGA Áron: Népmese és irodalomelmélet. = UÖ.: i. m. 116.

${ }^{558}$ Orosz Magdolna: Szöveg, fikció, intertextualitás. In: ÁRMEÁN Orsolya - FrIED István - OdORICS Ferenc (szerk.): Irodalomelmélet az ezredvégen. Gondolat - Pompeji, Bp., - Szeged, 2002. 67.

${ }^{559}$ LOSONCZ Alpár: Európa-dimenziók. Forum, Újvidék, 2002.
} 
korlátaival, határtapasztalataival, mindössze arra koncentrálhat, amit a médiumközi átmenetek nyomán a nyelviség, az irodalmi kontextus útvesztőiben beláthatott, a metafora mesekertjéből megpillanthatott, azzal az igyekezettel és figyelemmel, mely José Ortega y Gasset szerint is „,... saját korlátolt, esetleges tapasztalatunkon belül formálódik.”

A trópusok mesekertje mint szövegtér az irodalmi fikció útvesztőivel, Csáth Géza varázslójának egzotikus kertjével, Arisztotelész és Derrida napraforgójaival egy könyörtelen éden, ártalmakkal teli paradicsom, melynek az emberi civilizáció és kultúra alakulását meghatározó történései (s persze ezek értelmezései) nyomán, a mítoszok, mesék illuzórikus birodalmán át, napjaink szövegterébe, a borgesi elágazó ösvények kertjébe vezet az út. Igazi, valóságosnak hitt tartományán át, az ennek képét felöltő, mindezekre csalfa módon hasonlító vidékével egy feltérképezhetetlen övezet: reális (a 'realm' angol kifejezés szó eleji egyezéses, átfedéses összjátékával), amely már mindig areális. 


\section{Bibliográfia}

I. Irodalmi müvek:

CsÁTH Géza: Rejtelmek labirintusában. (Összegyüjtött esszék, cikkek tanulmányok, újságcikkek.) Szerk.: Szajbély Mihály. Magvető, Bp., 1995.

CSÁTH Géza: Egy elmebeteg nö naplója. Szerk.: Szajbély Mihály. Magvető, Bp., 1987.

CSÁTH Géza: Fej a pohárban. (Naplók és levelek 1914-16.) Szerk.: Szajbély Mihály. Magvető, Bp., 1997.

CSÁTH Géza: Mesék, amelyek rosszul végzödnek. (Összegyüjtött novellák.) Szerk.: Szajbély Mihály. Magvető, Bp., 1994.

CsÁTH Géza: A muzsika mesekertje. (Összegyüjtött írások a zenéröl.) Szerk. és sajtó alá rend.: Szajbély Mihály. Magvető, Bp., 2000.

CSÁTH Géza: (ifj. BRENNER József): Napló (1901-1904). Közread., szerk.: Dér Zoltán. Életjel - A szabadkai Szabadegyetem, Szabadka, 2007.

DÉRY Tibor: Kék üvegfigurák. Elbeszélések (1921-1929), versek (1916-1937). Sajtó alá rend.: Botka Ferenc, Magyar Irodalmi Múzeum, Bp., 1998.

DÉRY Tibor: Szerelem. Irodalmi forgatókönyv. Filmkultúra, 1967/4.

DÉRY Tibor: Theokitosz Újpesten. (Összegyüjtött novellák II.) Szépirodalmi, Bp., 1975.

HAJNÓCZY Péter: müvei. Szépirodalmi, Bp., 1982.

HOFFMANN, E.T.A.: A homokember. Európa, Bp., 1997.

JÓZSEF Attila: Szabad-ötletek jegyzéke. Antlantisz, Bp., 1990.

KRÚDY Gyula: Az útitárs. Osiris, Bp., 1999.

SZINI Gyula: A mese ,alkonya”. Nyugat, 1908/1.

SZINI Gyula: A rózsaszínü hó. Athenaeum, Bp., 1913.

Szini Gyula: Rózsaszinü hó. (Vál. és bevez. tan.: Vargha Kálmán.) Magvető, Bp., 1963.

Szini Gyula: Különös álmok. (Vál.: Téglás János.) Szépirodalmi, Bp., 1983.

SzINI Gyula: A smaragd és egyéb elbeszélések. Athenaeum, Bp., 1919.

SZINI Gyula: Stúdiumok. Bp., 1910.

SZINI Gyula: Lelki kalandok. Grill Károly Könyvkiadóvállalata (Magyar Írók Arany Könyvtára), Bp., 1908.

SzINI Gyula: Trilibi és egyéb történetek. Lampel R. Kk. Wodianer F. és Fia R. T., (Magyar Könyvtár 485. füzet), Bp., 1907.

ZALÁN Tibor: Kívül. Jelenkor, Pécs, 1993.

ZALÁN Tibor: Papírváros (egy lassúdad regény, egy - kimerülve). Kortárs, Bp., 1998.

ZALÁN Tibor: Papirváros kettö (Eltévedve). Kortárs, Bp., 2002.

ZALÁN Tibor: A szürrealista balkon. (Versek és (mü) fordítások.) Kortárs, Bp., 2004.,

ZÁvADA Pál: Milota. Magvetö, Bp., 2002. 


\section{Szakirodalom:}

A magyar irodalom történetei. 1-3. Föszerk.: SzEGEDY-MASZÁK Mihály. 3 kötet, Gondolat, Bp., 2007.

ABÁDI NAGY Zoltán: A trópus mint kulturalizációs narrativitás. In: KovÁCs Árpád (szerk.): A regény és a trópusok. (Tanulmányok. A második veszprémi regénykollokvium.) Diszkurzívák, Bp., 2007.

ADORNO, Theodor W.: Töredék a zenéröl és a nyelvröl. (Ford.: Csobó Péter.) Alföld, 2000/11.

ADY Endre: Szini Gyula. Nyugat, 1909/1.

ALEXA Károly: Eleitől fogva. (Tanulmányok, esszék.) Kortárs, Bp., 1996.

ALEXA Károly: Quodlibet. Kortárs, Bp., 2004.

AMBRUS Enikö: Csáth Géza és a pszichoanalízis. In: Dér Zoltán (szerk.): Emlékkönyv. (Csáth Géza születésnapjának századik évfordulójára.) Életjel, Szabadka, 1987.

ANGYALOSI Gergely: Romtalanitás. Kijárat, Bp., 2004.

ÁRMEÁN Orsolya - FRIED István - ODORICS Ferenc (szerk.): Irodalomelmélet az ezredvégen. Gondolat - Pompeji, Bp., - Szeged, 2002.

BACsÓ Béla (szerk.:) Szöveg és interpretáció. Cserépfalvi, Szekszárd, é.n.

BADINTER, Elizabeth: XY, avagy a férfiidentitásról. Cafe Babel, 1994/1-2.

BALÁZs Béla: Halálos fiatalság. Magyar Helikon, Bp., 1974.

BÁLINT Péter (szerk.): A meseszövés változatai. Didakt, Debrecen, 2003.

BÁNYAI János: A nyelv- és identitásváltás szomorúsága. Holmi, 2002/11.

BARTHES, Roland: Beszédtöredékek a szerelemröl. Atlantisz, Bp., 1997.

BARTHES, Roland: A szöveg öröme. Osiris, Bp., 1996.

BEARDSLEY, C. Monroe: A metaforikus csavar. Helikon, 1990/4.

BEDNANICS Gábor - EISEMANN György (szerk.): Induló modernség - kezdődő avantgárd. Ráció, Bp., 2006.

BELSEY, Catherine: A szubjektum megszólitása. Helikon, 1995/1-2.

BENJAMIN, Walter:: Kommentár és prófécia. Gondolat, Bp., 1969.

BENYOVSZKY Krisztián: Az elbeszélt metafora. Világosság, 2006/8-9-10.

BERNÁTH Árpád: Épitökövek. Ictus és JATE Irodalomelméleti Csoport, Szeged, 1998.

BERNÁTH Árpád: Metafora a lehetséges világok poétikájában. (Első rész: Arisztotelész Poétikája.)

In: ÁRMEÁN Orsolya - FRIED István - ODORICS Ferenc (szerk.): Irodalomelmélet az ezredvégen.

Gondolat - Pompeji, Bp., - Szeged, 2002.

BERTA Erzsébet: Literarchitektúra. Alföld, 1999/3.

BEZECZKY Gábor: A jelentésteremtö metafora. Helikon 1990/4

BEZECZKY Gábor: Metafora és elbeszélés. Literatura, 1992/1.

BEZECZKY Gábor: Metafora, narráció, szociolingvisztika. Akadémiai, Bp., 2002.

BEZECZKY Gábor: Véres aranykor, hosszú zsákutca. Balassi, Bp., 2005.

BíRÓ Yvette: A hetedik müvészet. Osiris. Bp., 1998.

BLACK, Max: A metafora. Helikon, 1990/4.

BLAU, Herbert: A test, amely meghaladja önmagát. Gondolat-jel, 1994/1-2.

BLumENBERG, Hans: Hajótörés nézövel. Atlantisz, Bp., 2006.

BóDIS Zoltán: Mese és szakrális kommunikáció. In: BÁLINT Péter (szerk.): A meseszövés változatai. (Mesemondók, mesegyüjtők és meseírók.) Didakt, Debrecen, 2003.

BODNÁR György: A „mese” lélekvándorlása. Szépirodalmi, Bp., 1988.

BÓKAY Antal: Szövegstruktúra, szövegvilág és irodalmi interpretáció. Literatura, 1981/1-2.

BÓNUS Tibor, KULCSÁR-SZABÓ Zoltán, SIMON Attila (szerk.): Az olvasás rejtekútjai. Ráció, Bp., 2007.

BóNUS Tibor: Garaczi László. Kalligram, Pozsony, 2002.

BORBÉLY Sándor: Tájékozódás. Irodalmi tanulmányok és kritikák. Magvető, Bp., 1986.

BORDÁs Sándor: Játék három figurával - Hajnóczy Péter Dinamit címü drámájának olvasata. In:

CSERJÉs Katalin - GYURIS Gergö (szerk.): Hová lettem. A párbeszéd helyzetébe kerülni.

Hajnóczy-tanulmányok. Lectum, Szeged, 2006.

BORI Imre: Prózatörténeti tanulmányok. Fórum, Újvidék, 1993.

BORI Imre: Varázslók és mákvirágok. Fórum. Újvidék, 1979. 
BOTKA Ferenc (szerk.): „D. T. úr X.-ben” (Tanulmányok és dokumentumok Déry Tiborról). Petőfi Irodalmi Múzeum, Bp., 1995.

BOTKA Ferenc: Mérlegen egy életmü. (Déry Tibor halálának huszonötödik évfordulóján rendezett tudományos konferencia előadásai.) Petőfi Irodalmi Múzeum, Bp., 2003.

CASETTI, Francesco: Filmelméletek 1945-1990. Osiris, Bp., 1998.

COPJEC, Joan: Read My Desire: Lacan Against the Historicists. MIT Press, Cambridge, 1995.

CSÁNYI Erzsébet: Világirodalmi kontúr. (Esszék, tanulmányok.) Forum - Iskolakultúra, Újvidék Pécs, 2000.

DANTO, Arthur C.: Hogyan semmizte ki a filozófia a müvészetet? Antlantisz, Bp., 1997.

DANTO, Artur C.: Metafora, kifejezés és stílus. In: Bacsó Béla (szerk.): Szöveg és interpretáció. Cserépfalvi, Szekszárd, é.n.

DARABOS Enikő: A trópusok hatalma. In: ÁRMEÁN Orsolya - ODORICS Ferenc (szerk.): Határon. Pompeji, Kolozsvár - Szeged

DE MAN, Paul: Az olvasás allegóriái. Ictus és JATE Irodalomelmélet Csoport, Szeged, 1999.

DE MAN, Paul: Esztétikai ideológia. Janus - Osiris, Bp., 2000.

DE MAN, Paul: Az önéletrajz mint arcrongálás. Pompeji, 1997/2-3.

DeleuZ, Gilles: Cinema 2. University of Minnesota Press, Minneapolis, 1989.

DELEUZE, Gilles - GUATTARI, Felix: Rizóma. Ex-Symposion, 1996/15-16.

DÉR Zoltán (szerk.): Emlékkönyv. (Csáth Géza születésnapjának századik évfordulójára.) Szabadka, 1987.

DÉR Zoltán: Ikercsillagok. Fórum, Újvidék, 1980.

DÉRCZY Péter: Az Adamec-villa titka. ÉS, 2002. július 19.

DERRIDA, Jacques: A fehér mitológia. (A metafora a filozófiai szövegben.) In: THOMKA Beáta (szerk.): Az irodalom elméletei V. Jelekor, Pécs 1997.

DERRIDA, Jacques: A retorika virágai: a napraforgó. Határ, 1994/2.

DÉRY Tibor: Botladozás. (Összegyüjtött cikkek, tanulmányok I.) Szerk.: Réz Pál, Szépirodalmi, Bp., 1978.

Dobos István: Az én színrevitele. (Önéletírás a XX. századi magyar irodalomban.) Balassi, Bp., 2005.

DoBos István: Az irodalomértés formái. Csokonai, Debrecen, 2002.

DOBOS István: Racionalitás és misztikum (A novellaíró Csáth). In: DÉR Zoltán (szerk.): Emlékkönyv. (Csáth Géza születésnapjának századik évfordulójára.) Szabadka, 1987.

DRAAISMA, Douwe: Metaforamasina. Typotex, h. n., 2002.

DUGIN, Alekszandr: Az erósz lázadása.

http://www.tradicio.org/kvintesszencia/trad99dugineros.htm

ECO, Umberto: Hat séta a fikció erdejében. Európa, Bp., 2002.

EISEMANN György (szerk.): A kánon peremén. (Az irodalmi modernség alakváltozatai a XIX-XX. század fordulójának magyar prózájában.) ELTE XVIII-XIX. Századi Magyar Irodalomtörténeti Tanszék, Bp., 1998.

EISEMANN György: A folytatódó romantika. Orpheusz, Bp., 1999.

ERÖS Ferenc: Jacques Lacan, avagy a vágy tragédiája. Thalassa, 1993/4.

FARAGÓ Kornélia: Kultúrák és narratívák. Forum, Újvidék, 2005.

FARKAS Katalin - KELEMEN János: Nyelvfilozófia. Áron, Bp., 2002.

FARKAS Zsolt: A lacani szubjektumról. Pompeji, 1994/5.

FEKETE Éva: Déry-Makk: Szerelem. Kritika, 1971/6.

FEKETE J. József: ,„Ügyesen szétgondolt olvasat” Zalán Tibor: Papírváros II. [Eltévedve]. Új Forrás, 2003/5.

FISH, Stanley: Van szöveg ezen az órán? In: ODORICS Ferenc (szerk.): Testes Könyv I. Ictus és JATE, Irodalomelméleti Csoport, Szeged, 1996.

FLETCHER, John (ed.): Abjection, Melancholia, and Love: The Work of Julia Kristeva. Routledge, London, 1990.

FOGARASI György - MÜLLNER András: Rátévedések. Ictus és JATE Irodalomelmélet Csoport, 1998.

FOUCAULT, Michel: A szavak és a dolgok. Osiris, Bp., 2000.

FOUCAULT, Michel: Felügyelet és büntetés. Gondolat, Bp., 1990. 
FOUCAULT, Michel: Nyelv a végtelenhez. Latin Betük, Debrecen, 2000.

FÖLDES Györgyi: A mese metafizikája és a magyar avantgárd. Irodalomtörténet, 2000/4.

FRANZ VON, Marie-Louise: Az árnyék és a gonosz a mesében. Európa, Bp., 1998.

FREUD, Sigmund: A kísérteties. (Ford.: Bókay Antal, Erős Ferenc.) In: BÓKAY Antal, ERŐs Ferenc (szerk.): Pszichoanalizis és irodalomtudomány. Szöveggyüjtemény. Filum, Bp., 1998.

FRYE, Northrop: Kettös tükör. Európa, Bp., 1996.

FRYE, Northrop: Myth and Metaphor. DENHAM D. Robert (ed.): Selected Essays 1974-1988. University Press of Virginia, 1990.

GANNON, Martin J. (ed.): Cultural metaphors: readings, research translations, and commentary. Thousand Oaks, California, 2001.

GÉCZI János: A tudása forrása: a kert. Magyar pedagógia. 1999/3.

GENETTE, Gérard: Metalepszis. Kalligram, Pozsony, 2006.

GENETTE, Gérard: Transztextualitás. Helikon, 1996/1-2.

GINTLI Tibor (szerk.): Változatok a modernitásra. Tanulmányok a Nyugatról. Anonymus, Bp., 2001.

GINTLi Tibor: Metafora és önazonosság Krúdy Gyula regénytöredékében. Iskolakultúra, 2004/6-7.

GOODMAN, Nelson: Az újraalkotott valóságról és a képek hangjairól. In: HORÁNYI Özséb (szerk.): A sokarcú kép. Válogatott tanulmányok a képek logikájáról. Typotex, Bp., 2003.

GYARMATI Krisztina: Esztétizmus és intermedialitás a századforduló prózájában. In: EISEMANN György (szerk.): A kánon peremén. (Az irodalmi modernség alakváltozatai a XIX-XX. század fordulójának magyar prózájában.) ELTE XVIII-XIX. századi magyar irodalomtörténeti tanszék, Bp., 1998.

GYIMESI Tímea: Az abject Julia Kristeva szubjektum-felfogásában. Helikon, 1995. 1-2.

H. NAGY Péter: Orfeusz feldarabolva. Ráció, Budapest, 2003. 11.

HAJDÚ Péter - RITOÓK Zsigmond (szerk.): Retorika és narráció. Gondolat - Pompeji, Bp., Szeged, 2007.

HANSÁGi Ágnes, Hermann Zoltán, HoRVÁTH Csaba, SzITÁR Katalin, TÖRÖK Lajos (szerk.): Egy csonk maradhat” Ráció, 2004.

HANSÁGI Ágnes: Az Ixión-szindróma. Ráció, Bp., 2006.

HEGYI Lóránd: Avantgarde és transzavantgarde. Magvető, Bp., 1986.

HITES Sándor: Szini Gyula-visszaírás. In: EISEMANN György (szerk.): A kánon peremén. (Az irodalmi modernség alakváltozatai a XIX-XX. század fordulójának magyar prózájában.) ELTE XVIII-XIX. Századi Magyar Irodalomtörténeti Tanszék, Bp., 1998.

HoLLÓsI Zsolt: „,Elfogynak a régi izek, csak a mítoszok maradnak meg” (Beszélgetés Zalán Tiborral.) Tiszatáj, 2001/11.

HONTI János: A mese világa. Magvető, Bp., 1962.

HoppÁL Mihály: Elbeszélés és emlékezet. Európai Folklór Intézet - Osiris, Bp., 2001.

HORÁNYI Özséb (szerk.): A sokarcú kép. Válogatott tanulmányok a képek logikájáról. Typotex, Bp., 2003.

HORVÁTH Kornélia - SzITÁR Katalin (szerk.): Szó - elbeszélés - metafora. (Müelemzések a XX. századi magyar próza köréböl.) Kijárat, Bp., 2003.

HORVÁTH Kornélia: A poétika fogalma a modern irodalomtudományi diskurzusban. In: RADVÁNSZKY Anikó (szerk.): , Ember lenni mindég, minden körülményben”-tanulmányok Kiczenko Judit születésnapja alkalmából. PPKE BTK, (Pázmány irodalmi mühely), Piliscsaba, 2008.

ISER, Wolfgang: A fiktív és imaginárius. Osiris, Bp., 2001.

JAKOBSON, Roman: Hang - Jel - Vers. Gondolat, Bp., 1969.

JÓZAN Ildikó - KULCSÁR-SZABÓ Ernő - SZEGEDY-MASZÁK Mihály (szerk.): Az elbeszélés módozatai. Osiris. Bp., 2003.

JUHÁsZ Attila: Emberszag, magányszag. Tiszatáj, 2003/2.

KANYÓ Zoltán (szerk.): Narratológiai tanulmányok. Studia Poetika 1. Szeged, 1980.

KELEMEN Pál: Metaforikus konstrukciók és olvasói szerepek Adalbert Stifter Bergkristall címü elbeszélésében. In: JÓZAN Ildikó - KULCSÁR-SZABÓ Ernő - SZEGEDY-MASZÁK Mihály (szerk.): Az elbeszélés módozatai. Osiris. Bp., 2003.

KELEMEN Pál: Útban a monológhoz? Elbeszélés és metafora Thomas Bernhardnál. In: Ua. 
KEMÉNY Gábor: Átutazóban a nagyepika felé. (Nyelvi képek, motívumok szövegszervező funkciója Déry Tibor Pesti felhöjátékában.) In: Szerk.: BOTKA Ferenc: Mérlegen egy életmü. (Déry Tibor halálának huszonötödik évfordulóján rendezett tudományos konferencia előadásai.) Petőfi Irodalmi Múzeum, Bp., 2003.

KEMÉNY Gábor: Bevezetés a nyelvi kép stilisztikájába. Tinta, Bp., 2002.

KIBÉDI VARGA Áron: Szavak, világok. Jelenkor, Pécs, 1988.

KIRÁLY Jenő: A borzalom esztétikája. Filmvilág, 1988/7.

KIRÁLY Jenő: Frivol múzsa. (A tömegfilm sajátos alkotásmódja és a tömegkultúra esztétikája.) 1. kötet, Nemzeti Tankönyvkiadó, Bp., 1993.

KIRÁLY Jenő: Mozifolklór és kameratöltőtoll. (A populáris filmkultúra elméletéhez.) Magyar filmtudomá-nyi intézet és filmarchivum, Bp., 1983.

KISS Attila: Gyönyörtelen színház, avagy a reprezentáció kitakarása. Gondolat-jel, 1994/1-2.

KoMLós Aladár: A szimbolizmus. Gondolat, Bp., 1965.

KoszTOLÁNy Dezső: Tükörfolyosó. Magyar írókról. Szerk.: Réz Pál, Osiris, Bp., 2004.

KosZTOLÁNYI Dezső: Nyelv és lélek. Szépirodalmi - Forum, Bp. - Újvidék, 1990.

KovÁCs Árpád (szerk.): A regény és a trópusok. (Tanulmányok. A második veszprémi regénykollokvium.) Diszkurzívák, Bp., 2007.

KovÁCs Árpád (szerk., vál.): Poétika és nyelvelmélet. Diszkurzívák, Bp., 2002.

KovÁCS Árpád: A költői beszédmód diszkurziv elmélete. In: KovÁCs Árpád - NAGY István (szerk.): A szótól a szövegig és tovább... (Tanulmányok az orosz irodalom és költészettan köréből.) Argumentum, Bp., 1999.

KRISTEVA, Julia: A szövegstrukturálás problémája. Helikon, 1996/1-2.

KRISTEVA, Julia: Powers of Horror. An Essay on Abjection. Columbia University Press, 1982.

KRISTEVA, Julia: The Adolescent Novel. In: John FlETCHER (ed.): Abjection, Melancholia, and Love: The Work of Julia Kristeva. Routledge, London, 1990.

KULCSÁR SZABÓ Ernő, SZIRÁK Péter (szerk.): Történelem, kultúra, medialitás. Balassi, Bp., 2003.

KULCSÁR SZABÓ Ernő: A magyar irodalom története 1945-1991. Argumentum, Bp., 1994.

KulCSÁR SZABÓ Ernő: Beszédmód és horizont. Argumentum, Bp., 1996.

KULCSÁR SZABÓ Ernő: Müalkotás - szöveg - hatás. Magvető, Bp., 1987.

KUNSZT György: A posztmodern épitészet antropomorfizmusa és dekonstruktista elvetése. Alföld, 1999/3.

LACAN, Jacques: Fonction et champ de la parole et du langage en psychanalyse = Uö.: Ecrits. A selection. Tavistock, London, 1977.

LEJENUE, Philippe: Önéletírás, élettörténet, napló. L’Harmattan, Bp., 2003.

LOSONCZ Alpár: Európa-dimenziók. Forum, Újvidék, 2002.

LOTMAN, Jurij: A retorika. Helikon, 1999/1-2.

LOTMAN, Jurij: Kultúra és intellektus. Argumentum, ELTE, Bp., 2002.

LOTMAN, Jurij: Kultúra, szöveg, narráció. JPE, Pécs, 1994.

LOVÁSZ Irén: Szakrális kommunikáció. Európai Folklór Intézet, Bp., 2002.

LUKÁCs György: Balázs Béla és akinek nem kell. (Összegyüjtött tanulmányok.) Kner Izidor, Gyoma, 1918.

MÁNDI Ildikó: Hangulat-szimbolikus mese (Szini Gyula: A sárga batár). In: MEZEI JózSEF (szerk.): Tanulmányok a XIX. Század magyar irodalmából. ELTE Bölcsészettudományi Kar, Bp., 1983.

MASZÁROVICS Ágnes, MÉSZÁROS Márton (szerk.): Jelenlét '07. (Tanulmányok.) Károli Gáspár Református Egyetem Bölcsészettudományi Kar, Irodalomtudományi Doktori Iskola kiadványi 3., Bp., 2009.

MELETYINSZKIJ, Jeleazar: A mitosz poétikája. Gondolat, Bp., 1985.

MenACHE, Sophia: The vox Dei. Oxford University Press, New York, 1990.

MEZEI JÓZSEF (szerk.): Tanulmányok a XIX. Század magyar irodalmából. ELTE

Bölcsészettudományi Kar, Bp., 1983.

NAGY Olga: Táltos és pegazus. Holnap, Bp., 1993.

NÉMETH Zoltán: Olvasáserotika. (Esszék, kritikák, tanulmányok - az élvezet szövegei.) Kalligram, Pozsony, 2000.

NIETZSCHE, Friedrich: A nem-morális felfogott igazságról és hazugságról. Athenaeum, 1992/3. 
OLASZ Sándor: Között. Forrás, 2001/10.

OLASZ Sándor: Regénymúlt, regényjelen. Széphalom Könyvmühely, Bp., 2006.

OROSZ Magdolna: „, Az elbeszélés fonala”. Gondolat, Bp., 2003.

OROSZ Magdolna: Szöveg, fikció, intertextualitás. In: ÁRMEÁN Orsolya - FRIED István - ODORICS

Ferenc (szerk.): Irodalomelmélet az ezredvégen. Gondolat - Pompeji, Bp., - Szeged, 2002.

OROSZ Magdolna: Utazás kultúrák között. In: BEDNANICS Gábor - EISEMANN György (szerk.): Induló modernség - kezdődő avantgárd. Ráció, Bp., 2006.

OSZTROLUCZKY Sarolta: Név és metafora Závada Pál Jadviga párnája címü regényében. In: HORVÁTH Kornélia - SzITÁR Katalin (szerk.): Szó - elbeszélés - metafora. (Müelemzések a XX. századi magyar próza köréből.) Kijárat, Bp., 2003.

PARKER, Patricia: Metafora és katakrézis. In: FÜZI Izabella - ODORICS Ferenc (szerk.): Figurák. Osiris - Pompeji, Bp., - Szeged, 2004.

PETŐFI S. János: A szöveg mint komplex jel. Akadémiai, Bp., 2004.

PFEIFFER, K. Ludvig: A mediális és az imaginárius. Egy kultúrantropológiai médiaelmélet dimenziói. Ráció, Bp., 2005.

POMOGÁTs Béla: Az emberség ereje. In: Déry Tibor: Niki Szerelem. Szerk.: Pomogáts Béla. Ikon, Matúra klasszikusok, Bp., 1995.

PoMOGÁts Béla: Búcsú az ifjúságtól (A Vörös Eszti című elbeszélés szerkezeti elemei). In: Dér Zoltán (szerk.): Emlékkönyv. (Csáth Géza születésnapjának századik évfordulójára.) Életjel, Szabadka, 1987.

POMOGÁTs Béla: Déry Tibor. Akadémiai, Bp., 1974.

RÁCZ I. Péter: A kánonok peremén. Iskolakultúra, 2001/2.

RICOEUR, Paul: Az élö metafora. Osiris, Bp., 2006.

RICOEUR, Paul: Válogatott irodalomelméleti tanulmányok. Osiris, Bp., 1999.

RIESMAN, David: A magányos tömeg. Közgazdasági és Jogi Könyvkiadó, Bp., 1983.

RouBAUD, Jacques: Költészet és emlékezet. Typotex, Bp., 2007.

S. HORVÁTH Géza: A szókép és a nyelv képe: a kétszólamú szó képi természete Mihail Bahtyin regényelméletében. Világosság, 2003/11-12.

SÁGHY Miklós: Filmszakadás a szövegtérben. (Mándy Iván Régi idők mozija című kötetének néhány jellegzetességéről.) In: HÓZSA Éva, SAMU JÁNOS Vilmos (szerk.):

Szakadás(köz)vetitések. (Irodalom és medialitás.) Forum - Újvidéki Egyetem, Magyar Tannyelvű Tanítóképző kar, Újvidék - Szabadka, 2008.

SCHULTZ Adrienn: Paradigmaváltó lehetöségek Szini Gyula novellisztikájában. In: MASZÁROVICS Ágnes, MÉszÁros Márton (szerk.): Jelenlét '07. (Tanulmányok.) Károli Gáspár Református Egyetem Bölcsészettudományi Kar, Irodalomtudományi Doktori Iskola kiadványi 3., (sorozatszerk.: Hima Gabriella), Bp., 2009.

SEBESTYÉN Attila: Agyvelö-akrobatika. Egy pszichofiziológiai müvészet-és kultúraelmélet keretei Csáth Gézánál. In: BÓNUS Tibor, KULCSÁR-SZABÓ Zoltán, SIMON Attila (szerk.): Az olvasás rejtekútjai. Müfajiság, kulturális emlékezet és medialitás a 20. századi magyar irodalomtudományban. Ráció, Bp., 2007.

SEREGI Tamás: Paul Ricoeur cselekvésontológiája. Világosság, 2007/1.

SIMONS, Jan: Film, Language and Conceptual Structures. University of Amsterdam, Amsterdam, 1995.

SZABÓ B. István: Déry Tibor és a film. In: „D. T. úr X.-ben” (Tanulmányok és dokumentumok Déry Tiborról.) Szerk.: Botka Ferenc, Petőfi Irodalmi Múzeum, Bp., 1995.

SZABÓ G. Zoltán - SzÖRÉNYI László: Kis magyar retorika. Helikon, Bp., 1997.

SZAJBÉLY Mihály: Csáth Géza. Gondolat, Bp., 1989.

SZAJBÉLY Mihály: Intermediális randevúk a 19. században. Pannónia, Pécs, 2008.

SZÁvai Dorottya: Mézes-mákos testamentum. (Závada Pál: Milota.) Kortárs, 2002/12.

SZEGEDY- MASZÁK Mihály: „Minta a szőnyegen”. Balassi, Bp., 1995.

SZEGEDY-MASZÁK Mihály: Az irodalmi elbeszélés elméleti kérdései. In: KANYÓ Zoltán (szerk.): Narratológiai tanulmányok. Studia Poetica 1. Szeged, 1980.

SZEGEDY-MASZÁK Mihály: Újraértelmezések: Esszék-irodalomról. Krónika Nova, Bp., 2000.

SZIGETI LAJOS Sándor: (De)formáció és (de)mitologizáció. (Parabolák és metaforák a modernitásban.) Messzelátó. Szeged 2000. 
SZILÁGYI Zsófia: Méhraj, galamb alakban. Bárka, 2002/6.

SZILVÁssY Orsolya: A lehatárolt interpretáció. Világosság, 2007/2-3.

SZITÁR Katalin: Szó és történetképzés Csáth Géza novelláiban. Schmith mézeskalácsos; Palincsay; Dénes Imre. In: GINTLI Tibor (szerk.): Változatok a modernitásra. Tanulmányok a Nyugatról. Anonymus, Bp., 2001.

TARJÁNYI Eszter: A mesenovella poétikai szerepe a századforduló irodalmában. (Ambrus Zoltán három mesenovellája.) Literatura, 2008/4.

THOMKA Beáta: A kárhozat grammatikája. In: Dér Zoltán (szerk.): Emlékkönyv. (Csáth Géza születésnap-jának századik évfordulójára.) Életjel, Szabadka, 1987.

THOMKA Beáta: A pillanat formái (A rövidtörténet szerkezete és müfaja.) Forum, Újvidék, 1986. 59.

THOMKA Beáta: Beszél egy hang. Kijárat, Bp., 2001.

THOMKA Beáta: Déry Tibor Országúton címü regényének szürrealista elemei. In: A magyar irodalmi avantgardról. A magyar nyelv, irodalom és hungarológiai kutatások intézete, (Értekezések monográfiák 10.), Újvidék, 1985.

THOMKA Beáta: Elbeszélés, poétika, historiográfia. In: ÁRMEÁN Orsolya - FRIED István ODORICS Ferenc (szerk.): Irodalomelmélet az ezredvégen. Gondolat - Pompeji, Bp., - Szeged, 2002.

THOMKA Beáta: Metafora, interpretáció, teória. Literatura, 1994/2.

THOMKA Beáta: Narráció és reflexió. Forum. Újvidék, 1980.

THURZÓ Gábor (szerk.): Ködlovagok. (Írói arcképek.) (Előszó: Márai Sándor.) Szt. István Társ., Bp., é. n. [1941.]

THURZÓ Gábor: Szini Gyula emléke. Nyugat, 1940/5.

TODOrOv, Tzvetan: Poétika. In: BóKAY Antal - VILCSEK Béla: A modern irodalomtudomány kialakulása. (A pozitivizmustól a strukturalizmusig, Szöveggyüjtemény.) Osiris, Bp., 2001.

TOLNAI Ottó: Útban a képzömüvész felé. In: Dér Zoltán (szerk.): Emlékkönyv. (Csáth Géza születésnapjának századik évfordulójára.) Életjel, Szabadka, 1987.

TOURNIER, Michel: A vámpír röpte. Napvilág, Bp., 2001.

VANYÓ László: Katakézis, költészet és ikonográfia a 4. században. Jel., Bp., 1995.

VARGHA Kálmán: A novellista Szini Gyula. ITK, 1963/3.

VARGHA Kálmán: Álom, szecesszió, valóság. Magvető, Bp., 1973.

VÍGH Árpád: Retorika és történelem. Gondolat, Bp., 1981.

VIRÁG Zoltán: A termékenység szövegtengere. (A regényíró Brasnyó István.) Forum-Messzelátó, Újvidék-Szeged, 2000.

VIRÁG Zoltán: Test(tér)kép. Korunk, 1997/9.

VOIGT Vilmos: A folklór stilisztikája és poétikája. In: HopPÁL Mihály (szerk.): Elbeszélés és emlékezet. Európai Folklór Intézet - Osiris, Bp., 2001.

VOIGT Vilmos: Szemiotikai kultúra - a kultúra szemiotikája. A debreceni Kossuth Lajos Tudományegyetem Néprajzi Tanszéke, Debrecen, 1990.

WHITE, Hayden: A történelem terhe. Osiris, Bp., 1997

Wolfgang ISER: A fiktiv és az imaginárius. Osiris, Bp., 2001.

ŽIŽEK, Slavoj: Az inherens törvényszegés avagy a hatalom obszcenitása. Thalassa, 1997/1.

ŽIŽEK, Slavoj: Lovagi szerelem és síró játék. Magyar Lettre, 1997. nyár. 51.

ZUMTHOR, Paul: A retorikusok útkeresztezödése. Helikon, 1996/1-2. 